JOSÉ PINTO RAMALHO

\title{
OXICORTE: ESTUDO DA TRANSFERÊNCIA DE CALOR E MODELAMENTO POR REDES NEURAIS ARTIFICIAIS DE VARIÁVEIS DO PROCESSO
}

Tese apresentada à Escola Politécnica da Universidade de São Paulo para obtenção do Título de Doutor em Engenharia

São Paulo 
JOSÉ PINTO RAMALHO

\section{OXICORTE: ESTUDO DA TRANSFERÊNCIA DE CALOR E MODELAMENTO POR REDES NEURAIS ARTIFICIAIS DE VARIÁ VEIS DO PROCESSO}

Tese apresentada à Escola Politécnica da Universidade de São Paulo para obtenção do Título de Doutor em Engenharia

Área de Concentração:

Engenharia Metalúrgica e de Materiais

Orientador:

Prof. Dr. Sérgio Duarte Brandi

São Paulo 
Este exemplar foi revisado e alterado em relação à versão original, sob responsabilidade única do autor e com a anuência de seu orientador.

São Paulo, 29 de julho de 2008

Assinatura do autor

Assinatura do orientador

\section{FICHA CATALOGRÁFICA}

José Pinto Ramalho

Oxicorte: Estudo da transferência de calor e modelamento por redes neurais artificiais de variáveis do processo/ José Pinto Ramalho. - São Paulo, 2008.

$129 \mathrm{p}$.

Tese (Doutorado) - Escola Politécnica da Universidade de São Paulo. Departamento de Engenharia Metalúrgica e de Materiais.

1. Oxicorte. 2. Transferência de calor. 3. Modelamento. 4. Rede Neural Artificial.

I. Universidade de São Paulo. Escola Politécnica. Departamento de Engenharia Metalúrgica e de Materiais II. T 
...As minhas obras não sou eu que as realiza,

Mas a força de Deus Pai que permeia os céus e a terra... 


\section{DEDICATÓRIA}

À minha amada Soraya, a pessoa mais interessante que conheci nesta vida.

Ao Pietro, ao Enrico e ao Giuseppe, que suportaram minha ausência durante a parte final deste trabalho. 


\section{AGRADECIMENTOS}

- Aos meus pais por terem me dado essa dádiva maravilhosa de viver;

- Ao Prof. Sérgio Brandi pelo que me ensinou, pela amizade, pela orientação, pelas discussões e por tudo o que compartilhamos neste período;

- Ao Mestre Flavio Issa, sem a ajuda dele este trabalho não se realizaria;

- Ao Freddy, Omar, Alberto, Livia, Gleisa, Josefina, Isabela, Manuel, Irineu, Francisco, Tatiana, Gisele, Claudia, Mauro, Tiago, Diana e Valdir Silvério colegas nas diferentes disciplinas que cursamos e nos ajudamos mutuamente;

- A Professora Neusa Falleiros pelo que me ensinou sobre termodinâmica;

- A Prof ${ }^{-a}$ Maria Elena Taqueda pelo que me ensinou sobre planejamento de experimentos e pelo despreendimento e disponibilidade de compartilhar o conhecimento;

- Ao Prof. Camacho pelo que me ensinou sobre gases e pela literatura que me cedeu;

- A Juliana por todo o trabalho na difração e por todo o companheirismo;

- A Carina pela disposição em ajudar e iniciativa de procurar soluções;

- A Liz, a Manoela e a Lília pelas discussoes e sugestões;

- A Eng ${ }^{\underline{a}}$ Silvana Vicente da AGA pelo empréstimo do regulador de oxigênio de alta pureza;

- Ao Erasmo e ao Edson da Hyperterm pelo emprestimo do dispositivo de corte;

- Ao Henrique Estanislau do LSI, meu amigo de infância, pelo servico de usinagem;

- Ao Livio, ao Danilo, ao Claudio e ao Rubens, técnicos dos laboratórios pelo apoio na execução dos trabalhos;

- Ao Alberto da empresa Matec por ter construído e me doado o equipamento para medição do fluxo dos gases;

- Ao Gimenes da Infosolda pelas discussões e por suportar minha ausência na empresa;

- A Sandvik e a FATEC pela usinagem dos corpos de prova;

- Ao Flávio pelo auxílio na medição da rugosidade e ajudas no laboratório;

- Ao Davi pelos trabalhos no estereoscópio e ajudas no laboratório;

- Ao Paulo do SENAI Osasco pelo empréstimo dos equipamentos de medição;

- A Prof ${ }^{a}$ Cida pelo auxílio com tradução e correção do texto;

- A todos aqueles que tiveram sua parcela de colaboração neste trabalho e eu infelizmente esqueci de citar e,

- Por último, onde deve ficar por direito: A todos aqueles que dificultaram, tentaram impedir ou criaram obstáculos de qualquer natureza para a realização e conclusão deste trabalho. 


\section{CURRICULUM VITAE - JOSÉ PINTO RAMALHO}

\section{Formação:}

- Doutor em Engenharia de Materiais - Escola Politecnica da USP - 2008

- Eng ${ }^{\circ}$ Industrial em Soldadura - Inst. de Soldadura e Qualidade de Lisboa - 1990

- Tecnólogo em Soldagem - FATEC SP - 1988

\section{Experiência profissional:}

- Consultor Técnico da Infosolda desde 2007

- Auditor avaliador da Fundação Vanzolini desde 2007

- Especialista em Soldagem e Corte - AGA SP de 1995 a 2007

- Assessor Técnico - ADIS SP - de 1993 a 1995

- Engenheiro de Soldadura - ISQ Lisboa (Portugal) - de 1990 a 1993

- Tecnólogo em Soldagem - IBQN (RJ) - de 1987 a 1990

- Técnico em Planejamento de Inspeção - Cobrasma (SP) - de 1986 a 1987

- Professor convidado da FATEC (SP) nas disciplinas: Metalurgia da Soldagem, Soldagem de Revestimentos e Processos de Soldagem.

\section{Prêmios:}

- 1 bolsa de estudos com isenção de taxas para o curso de engenharia em Portugal

- 1 Top Perform Club - Prêmio internacional recebido em Budapeste HU por ter sido um dos melhores profissionais do mundo da empresa AGA no ano de 1999

\section{Publicações (apenas as no âmbito desta tese):}

- RAMALHO, J.P.; BRANDI, S. D. Estudo cinético-metalúrgico do processo oxicorte. In: $5^{\circ}$ Simpósio de Iniciação Científica e Tecnológica, SP, 2003.

- RAMALHO, J.P.; BRANDI, S. D. A imprecisão da equação de Rosenthal no processo oxicorte. $5^{\circ}$. Simpósio de Iniciação Científica e Tecnológica, SP, 2003.

- RAMALHO, J.P.;ISSA, F.M.R. e PEREIRA,M.C. Proposta para comparação de performance entre redes neurais artificiais - VI SBAI Simpósio Brasileiro de Automação Inteligente - Bauru SP 2003

- RAMALHO, J.P.;ISSA, F.M.R. e BRANDI, S.D. Modelamento da superfície obtida por oxicorte utilizando redes neurais artificiais. XXXI Congresso Brasileiro de Soldagem, São Paulo, 2005.

- RAMALHO, J.P.;ISSA, F.M.R. e BRANDI, S.D. Estudo da influência de parâmetros de corte na largura da sangria no processo oxicorte. XXXIII Congresso Brasileiro de Soldagem, Caxias do Sul, 2007.

- RAMALHO, J.P., ANTONIASSI, J.L., SANT'AGOSTINO, L.M., BRANDI, S.D. Aplicação da DRX-Rietveld na quantificação de óxidos de ferro produzidos no oxicorte. IIW INTERNATIONAL CONGRESS 2nd Latin American Welding Congress, São Paulo, 2008.

- RAMALHO, J.P., BRANDI, S.D. Estudo da variação da temperatura e da pureza do oxigênio na composição dos óxidos no processo oxicorte. In: IIW INTERNATIONAL CONGRESS 2nd Latin American Welding Congress, São Paulo, 2008. 


\section{LISTA DE FIGURAS}

Figura

Descrição

Página

1 Comparativo entre velocidades de corte

2 Partes constituintes de uma chama oxi-combustível 10

$3 \quad$ Esquema de funcionamento do processo oxicorte 12

$4 \quad$ Gráfico percentual de $\mathrm{O}_{2}$ x temperatura $\quad 14$

5 Diferentes formas construtivas de bicos de corte para oxicorte 20

6 Variação das pressões conforme a espessura para maçarico misturador $\quad 21$

7 Variação da composição química da escória com a velocidade de corte 23

$8 \quad$ Percurso do jato de oxigênio através da chapa 24

9 Influência do teor de impurezas no desvio do corte 25

10 Influência do teor de impurezas e velocidade de corte 28

11 Simultaneidade da operação: chapas sobrepostas, dispositivo 29

12 Gastos com insumos no processo conforme o numero de maçaricos 29

13 Influência da simultaneidade no custo da operação 29

14 Gradiente térmico de uma peça aquecida 31

15 Mapa térmico espacial 31

16 Ciclos Térmicos e Repartição Térmica 32

17 Tipos de chamas 33

18 Balanço térmico no oxicorte para chapa de $15 \mathrm{~mm} \quad 40$

19 Calor da chama X calor de combustão no oxicorte 40

20 Relação entre concentração do $\mathrm{O}_{2}$ e velocidade de corte (chapa $25 \mathrm{~mm}$ ) 45

21 Relação entre concentração do $\mathrm{O}_{2}$ e vel. de corte (chapa $20 \mathrm{~mm}$ ) 45 
22 Desenho da preparação das peças 48

23 Painel montado para a medição e suprimento de diferentes gases 50

$24 \quad$ Caixa de captura dos óxidos e bancada 51

25 Sistema montado para a leitura da velocidade de avanço do maçarico 53

26 Medições de defasagem do corte e espessura da zona fundida realizadas 55

27 Medição da dimensão da ZAC do oxicorte 55

28 Montagem da fração menor que 0,074 mm para difração 57

29 Esquema de uma RNA MLP com backpropagation 63

30 Planos linearmente separáveis e não separáveis $\quad 64$

31 Variações médias na taxa de remoção de material 70

32 Padrão difractométrico refinado pelo método de Rietveld (amostra 2) 75

33 Medição da região fundida na borda superior $\quad 79$

34 Dimensão de região fundida relativa à espessura da chapa em função $\quad 81$

$\begin{array}{ll}\text { Porcentagem da região fundida relativa à espessura da chapa em } & 81\end{array}$ Comparação entre os teores de ferro na escória do oxicorte. Em (a) os

36 valores obtidos pela espessura da região fundida e em (b) porcentagem da região fundida relativa à espessura da chapa em função das condições experimentais utilizadas

37 Variação da largura da sangria em função da espessura da chapa e das condições experimentais utilizadas

38 Determinação da temperatura de corte com base na composição química dos óxidos da escória

39 Medição da ZAC nas peças cortadas (experimento 11) 89

40 Medição da ZAC nas peças cortadas (experimento 12) 89

41 Coordenadas empregadas no modelo de transferência de calor. 92

42 Gráfico para a obtenção de dados para cálculo da temperatura da

43 Calor total gerado no processo de corte em função da espessura da chapa e das condições experimentais utilizadas 
Razão entre o calor gerado pela chama e o calor devido à oxidação do

44 ferro e impurezas em função da espessura da chapa e das condições experimentais utilizadas

45 Ciclo térmico teórico para a chapa de $12 \mathrm{~mm}$ sem pré-aquecimento (linha contínua) e com pré-aquecimento (linha tracejada)

46 Rede Neural para estimativa do teor de Magnetita na escória

47 Rede Neural para estimativa do teor de Wustita na escória

48 Rede Neural para estimativa do teor de Fe na escória

49 Rede Neural para estimativa da dimensão da espessura fundida

50 Rede Neural para estimativa da dimensão da largura da sangria

51 Validação cruzada da rede para estimativa do teor de wustita

52 Validação cruzada da rede para estimativa do teor de magnetita

53 Validação cruzada da rede para estimativa do teor de ferro metálico 


\section{LISTA DE TABELAS}

Tabela

Descrição

Página

1 Comparativo entre os processos de corte

2 Algumas propriedades dos gases combustíveis utilizados no oxicorte

3 Defeitos e descontinuidades no oxicorte 1

4 Defeitos e descontinuidades no oxicorte 2

$5 \quad$ Algumas propriedades do ferro e seus óxidos

6 Influência da chama de aquecimento na combustão do fe

7 Composição química das chapas

8 Planejamento do Experimento - Chapas de 12,7 mm

9 Planejamento do Experimento - Chapas de 25,4 mm

10 Planejamento do Experimento - Chapas de 38,1 mm

11 Planejamento do Experimento - Chapas de 50,8 mm

12 Massa de material removida por peça

13 Remoção efetiva de material por peça

14 Análise da taxa de remoção do material

15 Balanço de massa e quantificação final

16 Relação entre os óxidos e os tratamentos

Comparação entre análise de óxidos por DRX e por espectroscopia de Mossbauer

18 Espessura da região fundida

19 Comparação entre as porcentagens de Fe

20 Valores calculados para a largura da sangria

21 Dimensões da ZAC em algumas peças cortadas 
22 Cálculo da energia gerada no corte conforme modelo de Grong ${ }^{[85]} \quad 95$

23 Dados utilizados para cálculo das quantidades de calor 96

24 Quantidade de calor entre as temperaturas iniciais das chapas e a 96

25 Cálculo da energia gerada no corte conforme metodologia de 98

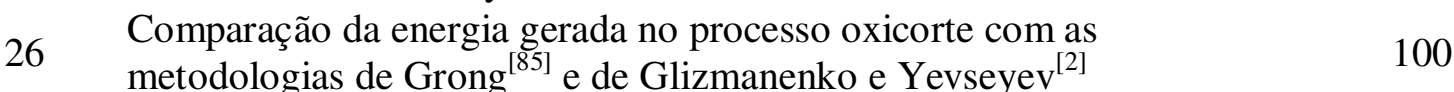

27 Configurações das redes utilizadas $\quad 109$ 


\section{LISTA DE SÍMBOLOS}

Símbolo

a Difusividade térmica

Q Potência calorífica

q Energia transmitida para o ponto $\mathrm{R}$

qo Energia transmitida para a peça

R Ponto localizado na chapa onde se estuda o fluxo de calor

t Tempo

$\mathrm{T}$ Temperatura a ser calculada no ponto de interesse

To Temperatura Ambiente

V Vazão

v Velocidade de soldagem

$\mathrm{x}, \mathrm{y}$ e $\mathrm{z} \quad$ Coordenadas do ponto $\mathrm{R}$

$\eta \quad$ Rendimento Térmico

$\mathrm{k}_{\mathrm{s}} \quad$ Coeficiente de transmissão térmica na superfície

$\xi \quad$ Coordenada móvel da dimensão do eixo "x"

$Q_{p} \quad$ Potência transmitida para o cordão de solda

k Condutividade Térmica

R' Ponto localizado na chapa considerando variação no eixo " $\mathrm{Z}$ "

Q Calor por unidade de tempo e de comprimento

g Espessura da chapa

$\alpha \quad$ Decréscimo da taxa de oxidação

Tc Temperatura de referência (temperatura de corte)
Unidade

$\mathrm{mm}^{2} / \mathrm{s}$

Watt

W

Watt

ad.

S

${ }^{\circ} \mathrm{C}$

${ }^{\circ} \mathrm{C}$

1/h

$\mathrm{mm} / \mathrm{s}$

$\mathrm{mm}$

ad.

$\mathrm{W} / \mathrm{mm}^{2}{ }^{\circ} \mathrm{C}$

$\mathrm{mm}$

W

$\mathrm{W} / \mathrm{mm}^{\circ} \mathrm{C}$

ad.

W

$\mathrm{mm}$

$\mathrm{ad}$

${ }^{\circ} \mathrm{C}$ 


\section{RESUMO}

O oxicorte produz superfícies que variam entre um padrão semelhante à usinagem até outro em que o corte é praticamente sem qualidade. Além das condições de equipamentos e habilidade de operadores, estas possibilidades são conseqüências da correta seleção de parâmetros e variáveis de trabalho.

O processo baseia-se numa reação química fortemente exotérmica, que gera parte de calor necessário para sua ocorrência juntamente com o restante do calor proveniente da chama do maçarico. A proporção entre estes valores é fortemente dependente, entre outros fatores, da espessura do material utilizado.

Este trabalho mostra como calcular a quantidade de energia gerada no oxicorte, com duas metodologias de diferentes autores, estuda de que maneira fatores como a variação da concentração do oxigênio e a temperatura inicial das chapas cortadas podem variar o balanço térmico e simula, com a utilização de Redes Neurais Artificiais, alguns dos dados necessários para a realização destes cálculos.

Para isto foram cortadas chapas de aço carbono ASTM A36 de 12,7 a 50,8 mm, com diferentes concentrações de $\mathrm{O}_{2}(99,5 \%$ e $99,95 \%)$ e diferentes temperaturas de préaquecimento das chapas $\left(30\right.$ e $\left.230 \pm 30^{\circ} \mathrm{C}\right)$. As superfícies cortadas foram caracterizadas, os óxidos produzidos identificados e os resultados foram correlacionados com o uso de tratamento matemático e técnicas de inteligência artificial.

Para a realização do trabalho alguns aspectos não existentes em literatura foram superados como o desenvolvimento de uma metodologia para a caracterização dos óxidos de Fe por meio de difração de raios $X$ com o método de Rietveld, a utilização de redes neurais artificiais para estimativa de resultados no processo oxicorte e a comparação entre 
diferentes redes neurais artificiais, que são também aspectos inéditos apresentados nos sete artigos técnicos publicados no decorrer deste trabalho.

Os resultados apresentam: uma metodologia para a análise da eficiência energética do processo, o desenvolvimento de técnicas que, com o emprego de inteligência artificial simulam o comportamento de aspectos do processo, o que por fim possibilita a simulação da análise de sua eficiência energética. 


\begin{abstract}
Oxygen cutting process produces surfaces that vary from a machine cut finishing to one of virtually no quality at all. Besides equipment conditions and operators' skills, these possibilities result from the correct selection of work parameters and variables.

The process is based on a highly exothermic chemical reaction that generates part of the heat needed for its occurrence, along with the rest of heat resultant from the flame of the blowpipe. The ratio between these values depends highly on the thickness of the material used.

This work shows how to calculate the amount of energy generated in the cutting process. Based on two methodologies of different authors, this research studies how factors such as the change in the oxygen concentration and the pre heating temperature of plates can vary the heat balance and simulates, with the use of Artificial Neural Networks, some of the data needed to perform these calculations.

ASTM A36 carbon steel plates, from 12.7 to $50.8 \mathrm{~mm}$ thick, with different oxygen concentration $(99,5 \%$ e $99,95 \%)$ and preheating temperatures (30 and $230 \pm 30$ oC) were cut. The cut surfaces and the produced oxides were characterized and the results were correlated with the use of mathematical treatment and artificial intelligence techniques.

In order to carry out this work some previously inexistent aspects in literature have been developed, such as a Fe oxides characterization methodology with X-ray diffraction and Rietveld method; the use of artificial neural networks to simulate the results in the oxygen cutting process and the comparison between different artificial neural networks, which are unpublished aspects of this work that can be seen in seven technical papers published while this work was in progress.
\end{abstract}


Results show: a methodology for the analysis of the energy efficiency of the process; the development of techniques that, together with artificial intelligence, simulate the results of aspects of the process; which finally allows the simulation analysis of the energy efficiency of the process. 
SUMÁRIO

Item

Descrição

Página

1 INTRODUÇÃO E JUSTIFICATICA

2 REVISÃO BIBLIOGRÁFICA 3

$2.1 \quad$ PROCESSOS DE CORTE DE MATERIAIS 3

$\begin{array}{lll}2.2 & \text { O PROCESSO OXICORTE }\end{array}$

$\begin{array}{lll}2.2 .1 & \text { HISTÓRICO } & 7\end{array}$

$\begin{array}{ll}\text { 2.2.2 INTRODUÇÃO AO PROCESSO } & 10\end{array}$

2.2.2.1 DIFERENTES GASES UTILIZADOS 13

2.2.3 PARÂMETROS E PRINCIPAIS VARIÁVEIS DO PROCESSO 16

2.2.3.1 PRÉ-AQUECIMENTO DO METAL DE BASE 17

2.2.3.2 ESPESSURA A SER CORTADA 17

2.2.3.3 GRAU DE PUREZA DO MATERIAL A SER CORTADO 17

2.2.3.4 DIÂMETRO E TIPO DO BICO DE CORTE 20

2.2.3.5 PRESSÃO E VAZÃO DOS GASES UTILIZADOS 21

2.2.3.6 VELOCIDADE DE AVANÇO DO MAÇARICO 22

2.2.3.7 GRAU DE CONCENTRAÇÃO DO OXIGÊNIO DE CORTE 23

2.2.4 DEFEITOS E DESCONTINUIDADES 26

2.2.5 A PRODUTIVIDADE E A RENTABILIDADE DO PROCESSO 27

2.3 FLUXO DE CALOR E REAÇÕES QUÍMICAS ENVOLVIDAS 30

2.3.1 CONSIDERAÇÕES INICIAIS SOBRE FLUXO DE CALOR 30

2.3.2 CICLOS TÉRMICOS E REPARTIÇÃO TÉRMICA 32

2.3.3 CALOR E RENDIMENTO TÉRMICO 32 
2.3.4 CÁlCULO DA DISTRIBUIÇÃO DA TEMPERATURA 34

2.3.5 PARTICULARIDADES TÉRMICAS NO OXICORTE 36

2.3.6 TERMODINÂMICA APLICADA NO OXICORTE 41

2.3.7 CONCENTRAÇÃO DO REAGENTE OXIGÊNIO 43

3 OBJETIVOS 46

$4 \quad$ MATERIAIS E MÉTODOS

4.1 CHAPAS DE AÇO CARBONO 47

4.2 GASES UTILIZADOS 49

4.3 BANCADA DE EXPERIMENTOS 50

4.4 PLANEJAMENTO DO EXPERIMENTO $\quad 51$

4.5 MEDIDA DA VELOCIDADE DE CORTE 53

4.6 MEDIÇÕES NAS SUPERFÍCIES CORTADAS 54

4.7 MEDIÇÃO DA ESPESSURA DA ZONA FUNDIDA E DA ZONA

4.8 ANÁLISE QUÍMICA DOS ÓXIDOS 55

4.8.1 PREPARAÇÃO DAS AMOSTRAS PARA DRX 57

4.8.2 O MÉTODO DE RIETVELD 57

4.9 REGRESSÃO LINEAR MÚLTIPLA $\quad 58$

4.10 REDES NEURAIS ARTIFICIAIS (RNA) 59

$\begin{array}{lll}\text { 4.10.1 ASPECTOS GERAIS DAS RNAS } & 60\end{array}$

4.10.2 IMPLEMENTAÇÃO DE REDES NEURAIS ARTIFICIAIS 61

4.10.3 RNA MULTILAYER PERCEPTRON COM BACKPROPAGATION 63

4.10.4 COMPARAÇÃO DE DESEMPENHO ENTRE REDES NEURAIS 65

4.11 COMBINAÇÃO DA REGRESSÃO MÚLTIPLA COM RNA 66 
$\begin{array}{lll}5 & \text { RESULTADOS E DISCUSSÃO } & 67\end{array}$

5.1 TAXA DE MATERIAL REMOVIDA POR PEÇA 67

5.2 COMPOSIÇÃO QUÍMICA DOS ÓXIDOS PRODUZIDOS 72

5.3 ESTIMATIVA DO TEOR DE FERRO NA ESCÓRIA DE

5.3.1 MEDIÇÃO DA ESPESSURA DA REGIÃO FUNDIDA

5.3.2 MEDIÇÃO DA LARGURA DA SANGRIA 84

5.4 TRANSFERÊNCIA DE CALOR NO OXICORTE 86

5.4.1 DETERMINAÇÃO DA TEMPERATURA DE CORTE 86

5.4.2 TRANSFÊRENCIA DE CALOR CONFORME MODELO DE 88

5.4.2.1 DIMENSÕES DA ZAC NAS PEÇAS ESTUDADAS 88

5.4.2.2 ADIMENSIONALIZAÇÃO DA EQUAÇÃO DE TRANSFERÊNCIA 90

5.4.2.3 CÁlCULO DA EXTENSÃO DA ZAC SEGUNDO GRONG ${ }^{[85]} 93$

5.4.2.4 CÁLCULO DA ENERGIA NO PROCESSO CONFORME MODELO 94

5.4.3 CÁLCULO DA QUANTIDADE DE CALOR GERADA NO
PROCESSO CONFORME GLIZMANENKO E YEVSEYEV

5.4.3.1 VALORES UTILIZADOS PARA O CÁLCULO 95

$\begin{array}{ll}\text { 5.4.3.2 CÁLCULO DA ENERGIA NO PROCESSO CONFORME MODELO } & 97 \\ \text { DE GLIZMANENKO E YEVSEYEV } & {[2]}\end{array}$

$\begin{array}{lll}\text { 5.4.4 COMPARAÇÃO ENTRE AS DIFERENTES METODOLOGIAS DE } & 100 \\ \text { CÁLCULO DA ENERGIA GERADA NO PROCESSO OXICORTE }\end{array}$

$\begin{array}{lll}\text { 5.4.5 CICLO TÉRMICO TEÓRICO } & 101\end{array}$

$\begin{array}{ll}\text { 5.5 EMPREGO DE REDES NEURAIS ARTIFICIAIS EM } & 102 \\ \text { MODELAMENTO } & \end{array}$

5.5.1 ARQUITETURA DAS RNAs UTILIZADAS 102

5.5.1.1 PARÂMETROS FIXOS UTILIZADOS NAS RNAs 102

5.5.1.2 PARÂMETROS VARIÁVEIS UTILIZADOS NAS RNAs 103

$\begin{array}{lll}\text { 5.5.1.3 CONJUNTOS DE DADOS TESTADOS } & 104\end{array}$ 
ESTIMATIVA DA COMPOSIÇÃO DOS ÓXIDOS COM REDES
NEURAIS

5.5.2.1 ESTIMATIVA DO TEOR DE MAGNETITA NA ESCÓRIA 106

5.5.2.2 ESTIMATIVA DO TEOR DE WUSTITA NA ESCÓRIA 106

5.5.2.3 ESTIMATIVA DO TEOR DE FERRO NA ESCÓRIA 107

$\begin{array}{lll} & \text { ESTIMATIVA DAS DIMENSOES DA ESPESSURA DA ZONA } & 108\end{array}$

$\begin{array}{lll}\text { 5.5.4 ESTIMATIVA DAS DIMENSOES DA LARGURA DA SANGRIA } & 108 \\ \text { COM A UTILIZAÇÃO DE REDES NEURAIS } & \end{array}$

5.5.5 RESUMO DAS CONFIGURAÇÕES UTILIZADAS NAS RNAS 109

$\begin{array}{lll}\text { 5.5.6 VALIDAÇÃO CRUZADA } & 109\end{array}$

$\begin{array}{llllllllll}\text { 5.5.6.1 } & \text { VALIDAÇÃO } & \text { CRUZADA } & \text { PARA } & \text { A } & \text { REDE } & \text { DO } & \text { TEOR } & \text { DE } & 110\end{array}$

$\begin{array}{llllllllll}\text { 5.5.6.2 } & \text { VALIDAÇÃO } & \text { CRUZADA } & \text { PARA } & \text { A } & \text { REDE } & \text { DO } & \text { TEOR } & \text { DE } & \\ \text { MAGNETITA } & & & & & & & & \end{array}$

5.5.6.3 VALIDAÇÃO CRUZADA PARA A REDE DO TEOR DE Fe 110

6 CONCLUSÕES 112

7 SUGESTÕES DE TRABALHOS FUTUROS 115

8 REFERÊNCIAS BIBLIOGRÁFICAS 116 


\section{INTRODUÇÃO E JUSTIFICATIVA}

As construções soldadas, de uma maneira geral são feitas de aço ao carbono e iniciam-se com o corte de uma chapa. O sucesso desta etapa é determinante para vários aspectos posteriores como: a qualidade, a velocidade e o custo da junta soldada a ser produzida. Nos casos em que a peça cortada venha a ser o produto final, a qualidade da superfície cortada é que determina se a peça deve ser retrabalhada ou não.

Desta forma a operação de corte tem uma importância muito grande no início da cadeia produtiva de diversas indústrias e, em especial, na indústria de bens de capital. Quando problemas na qualidade no corte causam retrabalho, todo o cronograma de uma obra sofre atraso, uma vez que os trabalhos de soldagem e montagem só iniciam após o sucesso desta etapa.

Atualmente os principais métodos empregados para o corte de aços são: Oxicorte, Plasma, Laser e Jato de Água. Desconsiderando o corte mecânico, devido sua natural limitação de inviabilizar-se com o aumento da espessura, o oxicorte é o mais antigo e utilizado destes métodos. Na faixa de espessuras acima de $35 \mathrm{~mm}$, ainda é o mais barato e mais utilizado método para o corte de chapas de aço ao carbono.

É um processo de fácil aprendizado e, em especial, em sua forma automatizada, de muito simples interface com o operador. Esta aparente facilidade faz com que o processo seja, muitas vezes, visto como tecnologicamente simples quando na verdade é um processo com campo de operação muito tolerante a regulagens de operação inadequadas.

Fora da regulagem correta o processo opera, mas produz superfícies cortadas de baixa qualidade que às vezes necessitam retrabalho, ou aumenta excessivamente o consumo de gases ou opera em baixas velocidades, isto é, opera de um modo que a operação como um todo apresente qualidade indesejada e/ou custo não competitivo. 
O principal aspecto que torna o processo economicamente interessante é o seu balanço energético. Ao contrário dos demais processos citados, o oxicorte gera, na reação química de oxidação do ferro do aço, boa parte do calor necessário para seu funcionamento. Enquanto nas chapas de menores espessuras o calor necessário é basicamente proveniente da chama do maçarico, nas espessuras maiores o calor é basicamente oriundo da reação química de oxidação do ferro. Deve haver uma faixa onde ocorra a transição dos modos de geração de calor durante o oxicorte.

Existe apenas um trabalho na literatura sobre a transferência de calor no corte (ROSENTHAL ${ }^{[1]}$, de 1941) e um que faz o balanço energético do processo (GLISMANENKO e YEVSEYEV ${ }^{[2]}$, de 1960). O trabalho de ROSENTHAL ${ }^{[1]}$ foi desenvolvido para soldagem com alguns ajustes para ser adaptado ao oxicorte. Não leva em consideração as diferentes energias dos óxidos produzidos nas diferentes reações químicas. O trabalho de GLISMANENKO e YEVSEYEV ${ }^{[2]}$ contorna o fato acima exposto ao adotar uma composição média de óxidos em função das espessuras, não estudando o efeito do préaquecimento e da concentração do $\mathrm{O}_{2}$ de corte na geração do calor durante o processo.

O presente trabalho tem como objetivo principal estudar a variação do balanço energético para diferentes espessuras, verificar a influência da concentração de $\mathrm{O}_{2}$ e do préaquecimento da chapa no processo e modelar por redes neurais artificiais a composição da escória para diferentes condições de corte, a área cortada e a área fundida pela chama de pré-aquecimento.

Para atingir estes objetivos será necessário estudar a influência das regulagens das variáveis na operação de corte como um todo, a qualidade da superfície cortada em particular, o ciclo térmico produzido, caracterizar as superfícies e os óxidos obtidos. Estes estudos farão uso de técnicas de caracterização dimensional da superfície cortada e de técnicas de caracterização de materiais como: Difração de Raios X (DRX), espectroscopia de Mossbauer, microscopia eletrônica de varredura (MEV) e análises micro e macrográficas. Para o estudo das variáveis serão feitos tratamentos matemáticos e com a técnica de inteligência artificial Redes Neurais Artificiais. 


\section{REVISÃO BIBLIOGRÁFICA}

Nesta revisão é feita uma abordagem inicial sobre os processos de corte aplicados aos materiais metálicos em geral, concentrando-se em seguida no processo oxicorte em particular.

\subsection{PROCESSOS DE CORTE DE MATERIAIS}

É possível separar os processos de corte de acordo com o princípio de funcionamento de cada um. O laser corta por fusão, arrancamento e $\operatorname{vaporização~}^{[3]}$; o plasma corta por fusão; o jato de água ${ }^{[4]}$ por um mecanismo que é uma mistura de microfratura e erosão e por fim o oxicorte, que corta por reação química de oxidação do ferro do aço, seguida de fusão e expulsão dos óxidos de ferro.

Cada um dos processos apresenta suas vantagens e desvantagens, sendo importante a compreensão individual de como cada um pode ser melhor empregado. RAMALHO e JOAQUIM $^{[3,5]}$ estudaram estes 4 processos de corte em diferentes trabalhos comparando-os 2 a 2. Além destes, vale citar também os trabalhos de: ARANTES $^{[4]}$, HIDDEN e

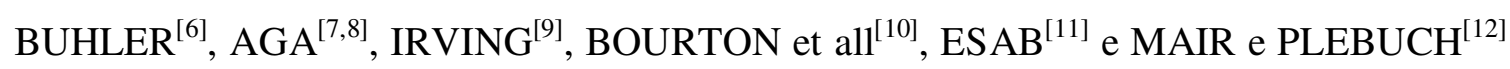
que também abordam a comparação entre processos. Com base na informação retirada destes trabalhos, foi adaptada a tabela 1, que apresenta características de cada um dos quatro processos de corte (oxicorte, plasma, jato de água e laser). Nesta tabela os índices 1 a 5 referem-se a características do processo que variam entre 1 (menor valor) a 5 (maior valor). 
TABELA 1 - COMPARATIVO ENTRE OS PROCESSOS DE CORTE

\begin{tabular}{|c|c|c|c|c|}
\hline \multirow{2}{*}{ Característica } & \multicolumn{4}{|c|}{ Processos } \\
\hline & Oxicorte & Plasma & Jato de Agua & LASER \\
\hline Espessura cortada & $5-1000 \mathrm{~mm}$ & $0-100 \mathrm{~mm}$ & $0-100 \mathrm{~mm}$ & $0-30 \mathrm{~mm}$ \\
\hline Qualidade do corte & 3 & 4 & 5 & 5 \\
\hline Nível de deformação & 4 & 3 & 1 & 2 \\
\hline Velocidade de corte & 1 & 2 & 3 & 5 \\
\hline Investimento inicial & 1 & 3 & 5 & 5 \\
\hline Largura do corte & 3 & 5 & 1 & 2 \\
\hline Custo de manutenção & 1 & 3 & 5 & 5 \\
\hline Materiais cortados & $\begin{array}{l}\text { Somente aço } \\
\text { ao carbono e } \\
\text { baixa liga }\end{array}$ & $\begin{array}{l}\text { Apenas } \\
\text { materiais } \\
\text { condutores } \\
\text { elétricos } \\
\end{array}$ & $\begin{array}{l}\text { Todos os } \\
\text { materiais }\end{array}$ & $\begin{array}{l}\text { Todos os } \\
\text { materiais não } \\
\text { reflexivos }\end{array}$ \\
\hline $\begin{array}{l}\text { Características } \\
\text { do } \\
\text { corte }\end{array}$ & $\begin{array}{l}\text { Reto, } \\
\text { depende de } \\
\text { pressão e } \\
\text { vazão do } \mathrm{O}_{2} \\
\text { de corte, do } \\
\text { bico e do } \\
\text { maçarico. }\end{array}$ & $\begin{array}{l}\text { Com desvio } \\
\text { angular, } \\
\text { sempre com a } \\
\text { largura da } \\
\text { sangria menor } \\
\text { na saída que na } \\
\text { entrada. }\end{array}$ & $\begin{array}{l}\text { Reto, } \\
\text { dependente da } \\
\text { pressão da água } \\
\text { e tipo de } \\
\text { abrasivo } \\
\text { utilizado. }\end{array}$ & $\begin{array}{l}\text { Reto, dependente } \\
\text { da intensidade do } \\
\text { feixe que diminui } \\
\text { conforme o } \\
\text { inverso do } \\
\text { quadrado da } \\
\text { distância do } \\
\text { foco }^{[13]} \text {. }\end{array}$ \\
\hline
\end{tabular}

As notações nestes trabalhos são entre 1 (menor valor) a 5 (maior valor)

Em relação a outros processos, o oxicorte apresenta os seguintes aspectos como vantagens $^{[6-13]}$ :

a) Disponibilidade: Diversos podem ser os combustíveis e o $\mathrm{O}_{2}$ é facilmente disponível. Além disto, para funcionar o processo não necessita eletricidade. Esta é necessária na automatização que pode ser acionada por motor, por exemplo, à gasolina.

b) Pequeno investimento inicial: Os materiais necessários como maçaricos, reguladores e mangueiras são relativamente baratos se comparados a outros processos de corte como plasma ou LASER, por exemplo. Cilindros de gás são normalmente alugados. 
c) Facilidade operacional: O processo é de fácil aprendizado e não possui muitas variáveis, sendo assim de fácil operação.

d) Baixa manutenção: Numa operação mecanizada ou automatizada os maiores cuidados com a manutenção são com as partes moveis dos equipamentos. No restante, assim como na operação manual, a manutenção é baixíssima, resumindo-se a cuidados com o manuseio e limpeza dos bicos de corte e verificação periódica do estado das mangueiras e reguladores, além da identificação de possíveis vazamentos.

E, como em todo processo produtivo, apresenta as seguintes desvantagens:

a) Restrições: Em função das condições necessárias para corte anteriormente descritas, diversas ligas metálicas de vasto uso industrial como aço inoxidável, latão, alumínio, cobre e suas ligas não podem ser cortadas com qualidade por este processo.

b) Portabilidade: Os materiais periféricos como cilindros de gás, são pesados e de difícil manuseio, o que dificulta o acesso a lugares altos ou postos de trabalho que se encontrem afastados dos cilindros. O transporte do conjunto de cilindros o expõe aos perigos adicionais como quedas, danificação das mangueiras condutoras de gases ou o mesmo ser atingido inadvertidamente.

c) Segurança: O oxigênio, além de ser um gás comburente, está sob alta pressão. $O$ acetileno é um gás inflamável e mais leve que o ar. Esta combinação requer que a manipulação de cilindros seja feita com cuidado, requerendo a utilização de equipamentos e procedimentos adequados para se evitar vazamentos e explosões. As mangueiras, reguladores, válvulas (unidirecionais e anti-retrocesso) e maçaricos devem ser constantemente inspecionados em sua funcionalidade e estanqueidade.

Com base nas informações disponíveis em catálogos e estudos de fabricantes de gases e equipamentos ${ }^{[14,15]}$ foi possível uma comparação das velocidades de corte, como a que é apresentada na figura 1. 


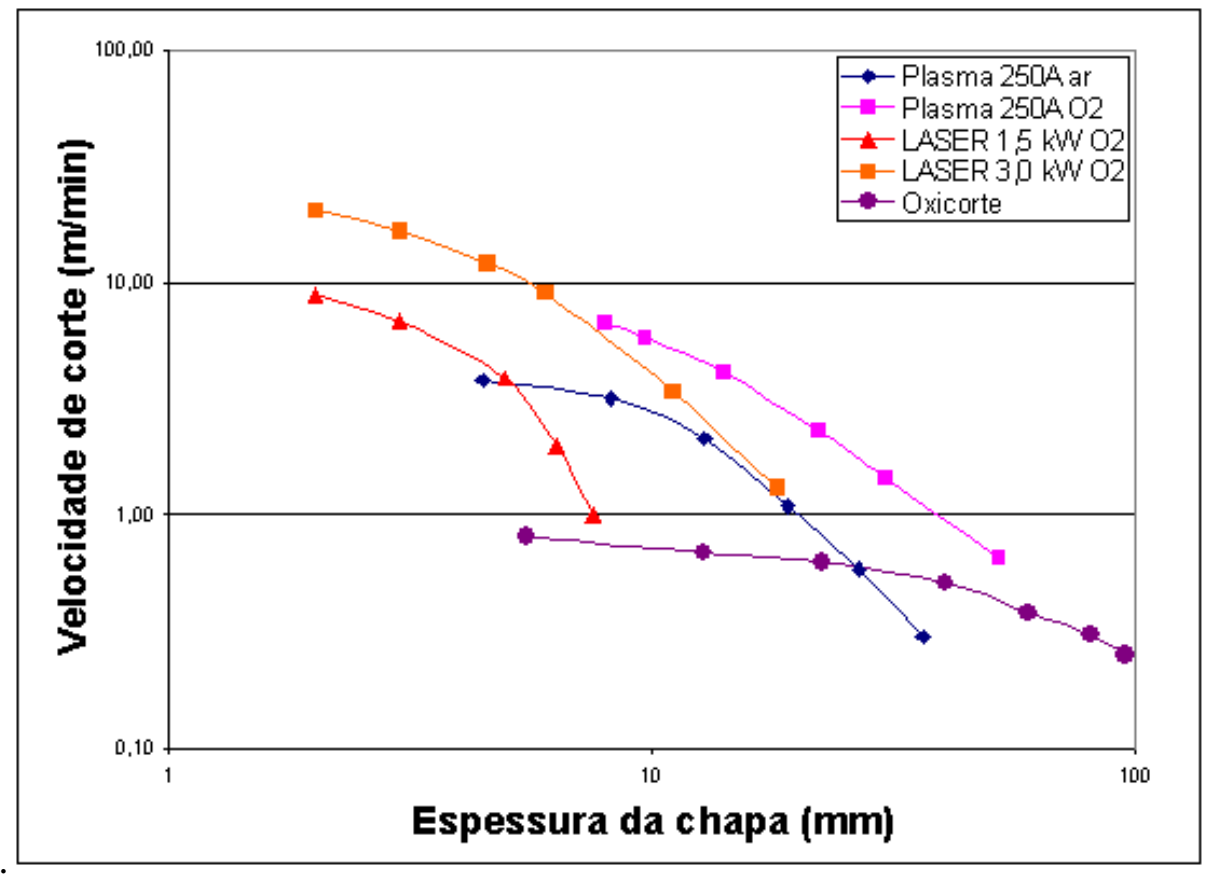

Figura 1 - Comparativo entre velocidades de corte. Adaptado de ${ }^{[14,15]}$.

Com o conhecimento da aplicabilidade de cada processo é possível fazer a escolha adequada levando-se em consideração o tópico de interesse para a operação desejada. Entre tópicos de interesse, é possível citar os analisados na tabela 1, além de considerações particulares como: disponibilidade de eletricidade para os casos de corte automatizado e mecanizado (que não é necessária ao oxicorte em si), possibilidade de reciclagem do abrasivo, necessária no jato de água, disponibilidade de bicos para o processo plasma entre outras.

Com base nas informações da tabela 1 e da figura 1 , conclui-se que o processo de corte com aplicabilidade aos aços ao carbono e em maiores espessuras, que apresenta o mais baixo custo por metro cortado, é o oxicorte. Assim, este processo é uma excelente opção para espessuras menores e é a escolha ideal para espessuras maiores que $50 \mathrm{~mm}$.

\subsection{O PROCESSO OXICORTE}

O processo oxicorte tem por volta de um século de existência. Esta antiguidade dá a idéia de um processo simples e que não apresenta mais nada a ser descoberto. De sua 
utilização inicial quase artesanal, o processo evoluiu para os modernos equipamentos que integram mesas de comando numérico (CNC), softwares de otimização do aproveitamento do corte (nesting) entre outros tópicos.

Não menos importante, por operar com gases e chama, é a segurança requerida no processo, destacada em trabalhos como os de ALMEIDA ${ }^{[16]}$, PARANHOS ${ }^{[17]}$ e HOULDCROFT e JOHN ${ }^{[18]}$ que apresentam as práticas e os devidos equipamentos e acessórios envolvidos para o funcionamento do processo com mínimos riscos para os operadores e pessoas que trabalham próximas a estes, além do trabalho do $\operatorname{CSTT}^{[19]}$ que engloba o oxicorte dentro de um trabalho maior que estuda todo o ambiente de soldagem e corte.

\subsubsection{HISTÓRICO}

O elemento oxigênio foi descoberto na Suécia pelo farmacêutico Carl Wilhelm Scheele em 1771. Em virtude de seu trabalho não ter obtido reconhecimento na época esta descoberta é erroneamente atribuída a Joseph Priestley, embora este tenha vindo a ocorrer, independentemente das pesquisas de Scheele, apenas em agosto de 1774. A razão deste equívoco histórico é que o trabalho de Scheele foi publicado em seu livro "Chemische Abhandlung von der Luft und dem Feuer" ("Tratado Químico sobre Ar e Fogo") apenas em $1777^{[20]}$. O nome de oxigênio foi dado por Lavoisier, em 1774, que significa em grego 'aquele que gera ácido, ${ }^{, 20]}$.

Em 1903 Mendeleyev sugeriu na Rússia o uso industrial do $\mathrm{O}_{2}$ para aumentar a velocidade no processo de produção de $\operatorname{aços}^{[21]}$, o que seu colega inglês Bessemer já fazia desde $1847^{[22]}$ em um modelo de conversor que até hoje leva seu nome.

O acetileno, descoberto na Inglaterra por Edmund Davy em 1836, foi sintetizado ${ }^{\text {[20] }}$ pela primeira vez pelo francês Marcellin Berthelot e batizado com o nome de acetileno por ele. Sua primeira produção para uso industrial data de 1892 com a finalidade de iluminação das ruas das cidades. 
Em 1895 Le Chatelier escreveu seu trabalho para a Academia Francesa de Ciências, onde descreveu a combustão de acetileno com $\mathrm{O}_{2}$. Neste trabalho foi quantificada a temperatura da chama oxi-acetilênica que, medida com a precisão da instrumentação da época, foi descrita como aproximadamente $2000^{\circ} \mathrm{C}$ maior que a temperatura da chama oxihídrica.

Conforme SLOTTMAN et $\mathrm{al}^{[23]}$, a primeira patente para a utilização do $\mathrm{O}_{2}$ para corte de materiais data de 1888. Foi solicitada por Tomas Fletcher em um trabalho enviado para a Sociedade da Indústria Química de Liverpool.

Em 1901, uma nova patente foi solicitada na Alémanha por Herman Menne e aplicava o corte com lanças de $\mathrm{O}_{2}$. Nesta época, problemas com a segurança do processo fizeram com que sua utilização fosse proibida por lei, porém em 1906 o corte com lança de $\mathrm{O}_{2}$ já era empregado nos EUA por Hans Mueller. Este corte, uma variação do oxicorte, é um processo ainda em uso atualmente. Ele consiste de um aquecimento inicial, seguido da alimentação de $\mathrm{O}_{2}$ através de um tubo consumível.

Com o objetivo de evitar confusão entre estes processos, o corte com lança é diferenciado na terminologia AWS (American Welding Society) pelo termo "oxygen cutting" (corte com $\mathrm{O}_{2}$ ), enquanto o oxicorte, que é um corte com gás combustível nesta mesma terminologia é designado como "flame cutting" (corte com chama).

Após a descoberta e disponibilização dos gases, a grande dificuldade passou a ser o manuseio do acetileno, uma vez que este não pode ser armazenado em pressões maiores que $1,5 \mathrm{k} / \mathrm{cm}^{2}$ uma vez que, como citado por LENSI ${ }^{[24]}$, o acetileno é um gás altamente exotérmico e, esta propriedade embora desejável para sua operação por aumentar o calor de combustão, é indesejável para seu manuseio pois faz com que o gás se torne explosivo caso em qualquer ponto de seu volume seja ultrapassada sua pressão ou temperatura de dissociação. $\mathrm{O}$ acetileno ${ }^{[25]}$ tem uma ligação tripla em sua fórmula estrutural e isto indica liberação de grande quantidade de calor durante a decomposição da molécula. O calor da ruptura desta ligação gera energia suficiente para a ruptura da molécula vizinha, desencadeando assim um processo de decomposição de todo o volume do gás. Isto causaria 
a liberação de grande quantidade de calor dentro do cilindro, explodindo-o.

Para contornar este problema duas soluções são empregadas:

(a) - A produção em volumes controlados no local de consumo através de geradores, forma esta quem vem paulatinamente sendo deixada de lado por problemas de segurança e;

(b) - Com a dissolução do produto em acetona e envasamento em cilindros contendo massa porosa, a forma mais utilizada atualmente. Um volume de acetona possibilita a dissolução de 25 volumes de acetileno, enquanto a massa porosa permite a saída do gás, mas não a da acetona, o que permite o armazenamento do acetileno em pressões de até $20 \mathrm{~kg} / \mathrm{cm}^{2}$.

Uma outra dificuldade a ser vencida no manuseio do acetileno foi a grande velocidade da chama oxi-acetilênica, $(7,6 \mathrm{~m} / \mathrm{s})^{[26,27]}$ que requereu desenvolvimento de válvulas adequadas para suportar os retrocessos de chama e de gases que podem ocorrer no processo $^{[25,28]}$. Todo este desenvolvimento partiu de equipamentos para soldagem, que foram sendo adaptados para as condições de corte.

Em 1905, Jottrand apresentou sua patente para um maçarico de corte ${ }^{[23]}$. Anos depois, apareceram os primeiros maçaricos com bicos de corte contendo orifício central para o jato de $\mathrm{O}_{2}$, forma esta que é a utilizada até hoje.

O desenvolvimento de acessórios ${ }^{[29,30]}$ como: reguladores de pressão mais estáveis, válvulas de segurança, além do aprimoramento da forma construtiva dos cilindros de armazenamento dos gases, possibilitaram mais estabilidade e confiabilidade ao processo, o que deu a forma com a qual o oxicorte é utilizado até hoje.

Outro aspecto importante para o desenvolvimento do processo foi a utilização de outros combustíveis além do acetileno, assunto estudado por SLOTMANN ${ }^{[23]}$, que apresenta no trabalho "OXYGEN CUTTING” um capítulo sobre este assunto chamado “combustíveis alternativos ao acetileno", e também por VAN HORN ${ }^{[31]}$. 
Atualmente ${ }^{[32-38]}$, o processo opera além do acetileno, com diferentes gases combustíveis como: propano, propileno e butano, entre outros, além de misturas especialmente desenvolvidas. É importante destacar que são necessárias algumas alterações no equipamento para o funcionamento com diferentes combustíveis ${ }^{[39,40]}$, como por exemplo troca do bico de corte e do injetor de $\mathrm{O}_{2}$.

\subsubsection{INTRODUÇÃO AO PROCESSO}

O oxicorte pode ser definido como um processo de seccionamento de metais por uma combustão localizada e contínua causada pela ação de um jato de $\mathrm{O}_{2}$ de elevada concentração, que age sobre um ponto previamente aquecido por uma chama oxicombustível $^{[41]}$.

No oxicorte, a chama oxi-combustível tem a função de aquecimento do metal. A combustão do acetileno produz uma chama primária conhecida como dardo e uma secundária conhecida como penacho.

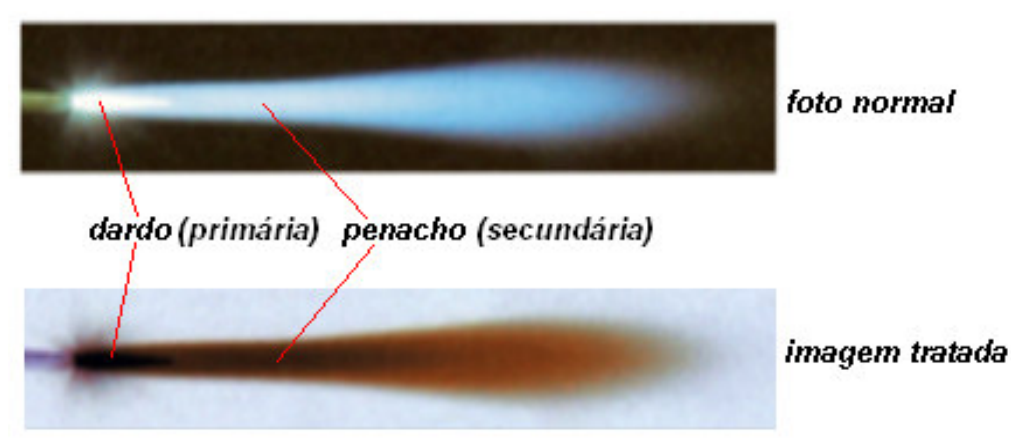

Figura 2 - Partes constituintes de uma chama oxi-combustível

A chama primária utiliza o $\mathrm{O}_{2}$ proveniente da mangueira e pode ser descrita pela equação a seguir ${ }^{[42,43]}$ :

$$
C_{2} H_{2_{(g)}}+O_{2_{(g)}} \Leftrightarrow 2 \mathrm{CO}_{(g)}+H_{2_{(g)}} \quad \Delta \mathrm{H}=-493,8 \mathrm{~kJ} / \mathrm{mol}
$$


As reações na chama secundária são de dois tipos: no interior e na borda desta. A diferença é que no interior da chama secundária o $\mathrm{O}_{2}$ é ainda proveniente da alimentação das mangueiras do sistema, enquanto que nas bordas o $\mathrm{O}_{2}$ é proveniente do ar atmosférico.

$\mathrm{O}$ ar atmosférico apresenta uma composição aproximada de $20,947 \%$ de $\mathrm{O}_{2}$, $78,084 \%$ de $\mathrm{N}_{2}$ e $0,934 \%$ de $\operatorname{Ar}^{[44]}$ e tanto o $\mathrm{N}_{2}$ como o $\mathrm{Ar}$ não participam da reação secundária, porém por saírem aquecidos desta acabam por retirar-lhe calor. Este fato impossibilita o aproveitamento da totalidade do calor da chama e é uma das razões porque existe a diferença entre as temperaturas real e teórica de chama.

A reação do interior da chama secundária é descrita na equação a seguir ${ }^{[42]}$ :

$$
4 C O_{(g)}+2 H_{2_{(g)}}+3 O_{2_{(g)}} \Leftrightarrow 4 \mathrm{CO}_{2_{(g)}}+2 \mathrm{H}_{2} O_{(g)} \quad \Delta \mathrm{H}=-769,4 \mathrm{~kJ} / \mathrm{mol}
$$

Enquanto as reações das bordas da chama secundária são descritas por:

$$
\begin{aligned}
& 2 \mathrm{CO}_{(8)}+O_{2_{(8)}}+3,72 \mathrm{~N}_{2_{(8)}}+0,04 A r_{(8)} \Leftrightarrow 2 \mathrm{CO}_{2_{(8)}}+3,72 \mathrm{~N}_{2_{(8)}}+0,04 A r_{(8)} \quad \Delta \mathrm{H}=-283,19 \mathrm{~kJ} / \mathrm{mol} \\
& 2 \mathrm{H}_{2_{(8)}}+\mathrm{O}_{2_{(8)}}+3,72 \mathrm{~N}_{2_{(8)}}+0,04 A r_{(8)} \Leftrightarrow 2 \mathrm{H}_{2} \mathrm{O}_{(8)}+3,72 \mathrm{~N}_{2_{(g)}}+0,04 A r_{(8)} \quad \Delta \mathrm{H}=-241,95 \mathrm{~kJ} / \mathrm{mol}{ }_{\text {(vapor) }}
\end{aligned}
$$

Quando o processo utiliza acetileno, a regulagem da chama é neutra, ou seja, com este gás 2,5 volumes de $\mathrm{O}_{2}$ são consumidos para a completa combustão de cada volume de acetileno, sendo 1,1 volumes deste $\mathrm{O}_{2}$ provenientes das mangueiras e 1,4 volumes do ar atmosférico.

A regulagem inicial do maçarico deve ser feita mantendo-se aberto o jato de $\mathrm{O}_{2}$ de corte, para que seja regulado na condição dinâmica do processo. Para o início da operação o jato de $\mathrm{O}_{2}$ de corte deve ser fechado, iniciando assim o aquecimento da peça a cortar.

Quando o material a cortar estiver na temperatura ideal para o início da oxidação, conhecida como temperatura de oxidação viva, é então aberto novamente o jato de corte, iniciando assim o processo. Uma vista esquemática do processo é apresentada na figura 3. 


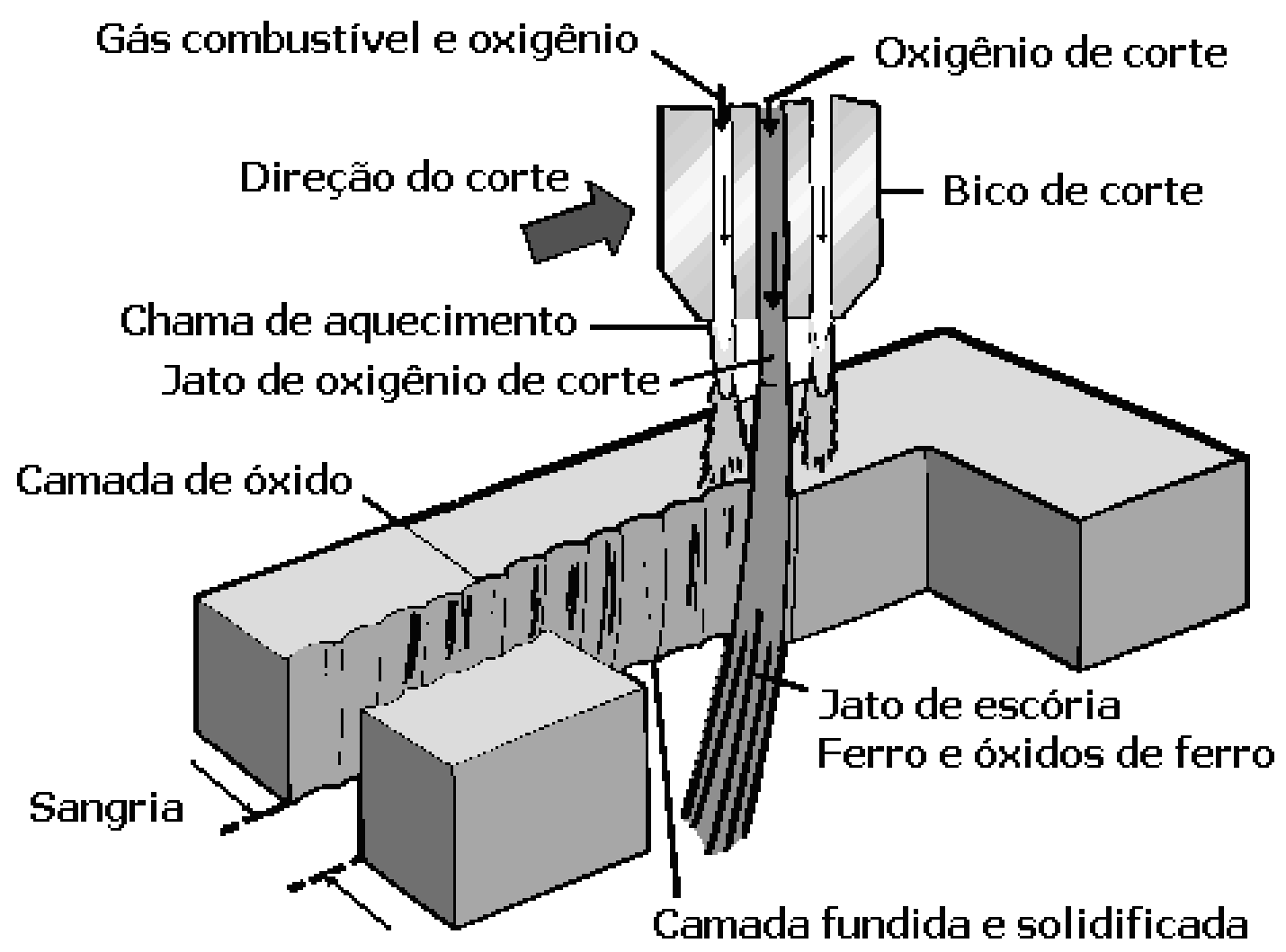

Figura 3 - Esquema de funcionamento do processo oxicorte ${ }^{[12]}$

$\mathrm{Na}$ temperatura ambiente e na presença de $\mathrm{O}_{2}$, o ferro oxida-se lentamente, porém conforme a temperatura aumenta, esta oxidação se acelera, tornando-se praticamente instantânea a $1350^{\circ} \mathrm{C}^{[45]}$. Nesta temperatura, a citada de temperatura de oxidação viva, o calor fornecido pela reação é suficiente para liquefazer o óxido formado e realimentar a reação.

$\mathrm{O}$ óxido no estado líquido se escoa expulso pelo jato de $\mathrm{O}_{2}$, o que permite o contato do ferro devidamente aquecido com $\mathrm{O}_{2}$ puro, dando continuidade ao processo.

As condições básicas para a ocorrência do oxicorte são as seguintes ${ }^{[41,46-48]}$ :

a) a temperatura de início de oxidação viva ser inferior à de fusão do metal;

b) a reação ser suficientemente exotérmica para manter a peça na temperatura de início de oxidação viva; 
c) os óxidos formados manterem-se no estado líquido na temperatura de oxicorte, para facilitar o escoamento e permitir a continuidade do processo;

d) o material a ser cortado ter baixa condutividade térmica;

e) os óxidos formados terem alta fluidez.

Cumpridas todas estas condições, o ferro reage com o $\mathrm{O}_{2}$ proveniente do cilindro através do maçarico e do bico de corte, uma vez que o ferro em seu estado metálico é menos estável que em seu estado de óxido.

No processo de corte esta reação é acelerada, havendo um considerável ganho exotérmico. As reações químicas do ferro puro com $\mathrm{O}_{2}$ podem ser descritas pelas seguintes equações $^{[41,46,49,50]}$ :

$$
\begin{array}{cc}
\mathrm{Fe}_{(s)}+1 / 2 \mathrm{O}_{2_{(g)}} \Leftrightarrow \mathrm{FeO} O_{(s)} & \Delta \mathrm{H}=-269 \mathrm{~kJ} / \mathrm{mol} \text { de ferro } \\
2 F e_{(s)}+3 / 2 \mathrm{O}_{2_{(g)}} \Leftrightarrow F e_{2} O_{3_{(s)}} & \Delta \mathrm{H}=-412,1 \mathrm{~kJ} / \mathrm{mol} \text { de ferro } \\
3 F e_{(s)}+2 O_{2_{(g)}} \Leftrightarrow F e_{3} O_{4_{(s)}} & \Delta \mathrm{H}=-372,8 \mathrm{~kJ} / \mathrm{mol} \text { de ferro }
\end{array}
$$

\subsubsection{DIFERENTES GASES UTILIZADOS}

Além do acetileno, outros gases também podem ser utilizados no processo. Estequiometricamente gases de diferentes composições necessitam de diferentes quantidades de $\mathrm{O}_{2}$ para sua combustão completa e, esta diferença no volume de $\mathrm{O}_{2}$ consumido vem a ser um dos fatores que determinam a escolha por um determinado gás combustível. Entre estes gases podemos citar o propileno, propano e o GLP. Este último apresenta no Brasil uma composição de propano e butano. As reações destes gases são descritas pelas equações a seguir: 


$$
\begin{array}{ll}
C_{3} H_{6_{(g)}}+4,5 O_{2_{(g)}} \Leftrightarrow 3 \mathrm{CO}_{2_{(g)}}+3 \mathrm{H}_{2} O_{(g)} & \Delta \mathrm{H}=-1923,3 \mathrm{~kJ} / \mathrm{mol} \\
C_{3} H_{8_{(g)}}+5 O_{2_{(g)}} \Leftrightarrow 3 \mathrm{CO}_{2_{(g)}}+4 \mathrm{H}_{2} O_{(g)} & \Delta \mathrm{H}=-2042,05 \mathrm{~kJ} / \mathrm{mol} \\
C_{4} H_{10_{(g)}}+6,5 O_{2_{(g)}} \Leftrightarrow 4 \mathrm{CO}_{2_{(g)}}+5 \mathrm{H}_{2} O_{(g)} & \Delta \mathrm{H}=-2655,88 \mathrm{~kJ} / \mathrm{mol}
\end{array}
$$

HEWITT $^{[35,36]}$ e ALSTRÖN e BRODEN ${ }^{[50]}$ e RAMALHO ${ }^{[51]}$ mostram em um gráfico enquanto EKLUND ${ }^{[52]}$ e COUCH e SILKNITTER ${ }^{[53]}$ discutem os diferentes combustíveis possíveis de ser utilizados no processo. Destes trabalhos foi adaptado o gráfico mostrado na figura 4.

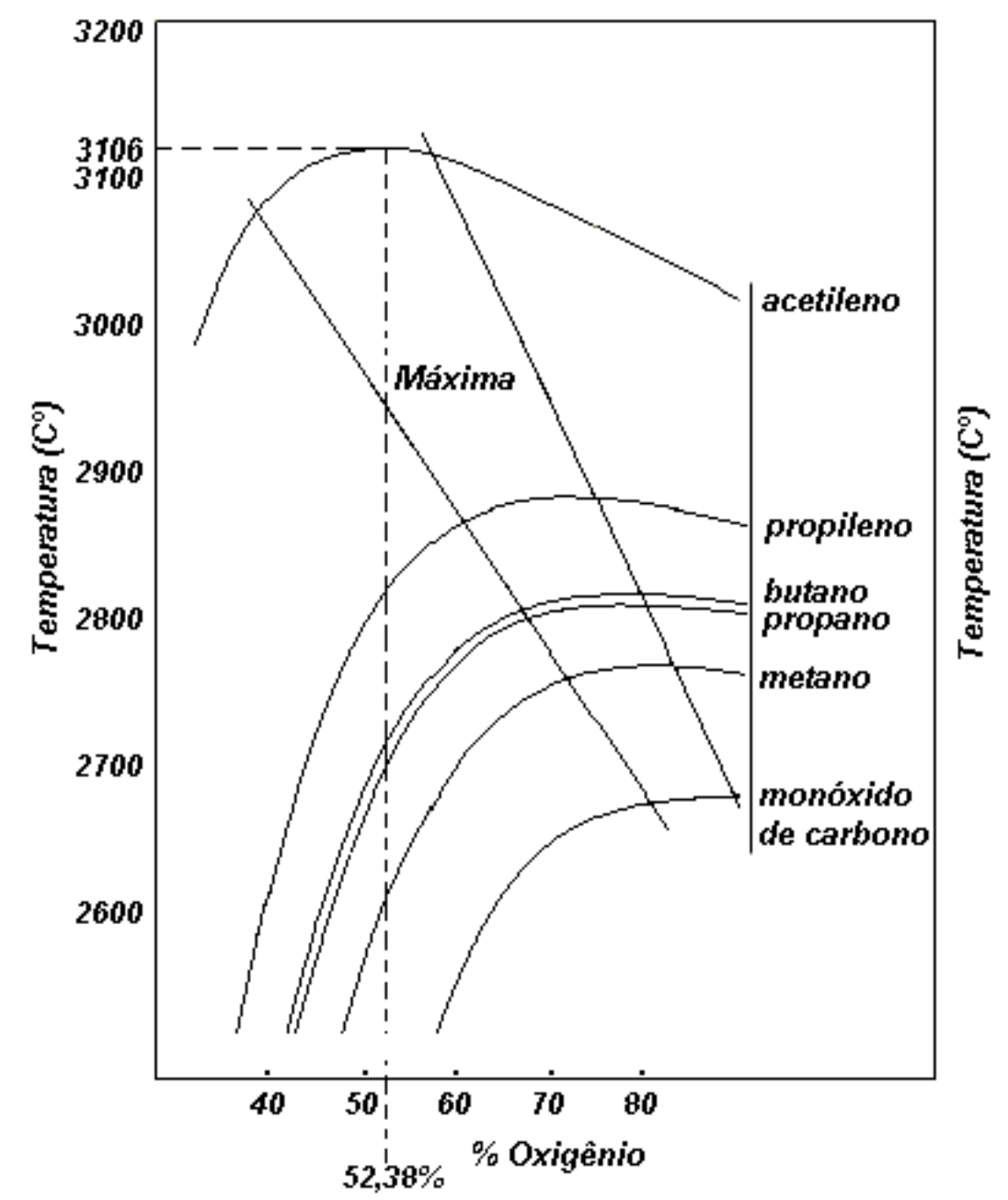

Figura 4 - Gráfico percentual de $\mathrm{O}_{2} \mathrm{x}$ temperatura, adaptado de ${ }^{[51,52]}$ 
Como pode ser observado na figura 4, para o gás acetileno a maior temperatura é por volta de $3106^{\circ} \mathrm{C}$, para uma porcentagem de oxigênio de $52,38 \%$, cuja composição se obtém a maior temperatura teórica de chama para este gás. Esta procentagem é correspondente a uma regulagem com a proporção de 1,1 partes de $\mathrm{O}_{2}$ para cada parte de acetileno, ou seja:

$$
\% O_{2}=\frac{1,1 \times 100}{1+1,1}=52,38
$$

O acetileno é, de todos os gases utilizados no processo, o gás com a maior relação carbono/hidrogênio com o valor de 1 . Os demais gases utilizados apresentam para esta relação valores menores, como pode ser visto na tabela a seguir.

TABELA 2 - ALGUMAS PROPRIEDADES DOS GASES COMBUSTÍVEIS UTILIZADOS NO OXICORTE

\begin{tabular}{|c|c|c|c|c|c|c|c|}
\hline \multirow[b]{2}{*}{ Gás } & \multirow{2}{*}{$\begin{array}{c}\text { Relação } \\
\text { C/H }\end{array}$} & \multicolumn{2}{|c|}{ Chama } & \multicolumn{2}{|c|}{$\begin{array}{l}\text { Razão } \mathrm{O}_{2} / \text { vol de } \\
\text { combustível }^{[54]}\end{array}$} & \multicolumn{2}{|c|}{ Resíduos $^{[55]}$} \\
\hline & & $\begin{array}{l}\text { Velocidade de } \\
\text { propagacãão } \\
(\mathrm{m} / \mathrm{s})^{[56]}\end{array}$ & $\begin{array}{c}\text { Temperatura } \\
\text { máxima } \\
\left({ }^{\circ} \mathrm{C}\right)^{[52]}\end{array}$ & $\begin{array}{l}\text { Chama } \\
\text { normal }\end{array}$ & $\begin{array}{l}\text { Estequio- } \\
\text { Métrica }\end{array}$ & $\begin{array}{c}\mathrm{Mol} \mathrm{N}_{2}+\mathrm{Ar} / \mathrm{mol} \\
\text { combustível }\end{array}$ & $\begin{array}{c}\text { Mol de } \\
\text { fumos/mol } \\
\text { combustível }\end{array}$ \\
\hline $\mathrm{C}_{2} \mathrm{H}_{2}$ & $2 / 2=1$ & $9,49-12,77$ & 3106 & 1,1 & 2,5 & 5,283 & 3 \\
\hline $\mathrm{C}_{3} \mathrm{H}_{6}$ & $3 / 6=0,5$ & $4,53-4,62$ & 2872 & 3,1 & 4,5 & 5,283 & 6 \\
\hline $\mathrm{C}_{4} \mathrm{H}_{10}$ & $4 / 10=0,4$ & $3,34-3,55$ & 2845 & 5,0 & 6,5 & 5,661 & 9 \\
\hline $\mathrm{C}_{3} \mathrm{H}_{8}$ & $3 / 8=0,375$ & $3,60-4,01$ & 2810 & 4,0 & 5,0 & 3,774 & 7 \\
\hline
\end{tabular}

Conforme CAMACHO ${ }^{[55]}$ os resíduos são parte importante a ser calculada numa combustão uma vez que roubam calor da mesma ajudando diminuir a temperatura máxima de chama a ser atingida. O residual de $\mathrm{N}_{2}+\mathrm{Ar}$ do ar atmosférico existente na reação é calculado multiplicando dois fatores: (a) o resultado da subtração do $\mathrm{O}_{2}$ consumido na chama normal do volume estequiométrico total, e (b) a razão entre o total da composição química do ar atmosférico menos o teor de $\mathrm{O}_{2}$ dividido pelo teor de $\mathrm{O}_{2}$ no ar atmosférico. Exemplificando para $\mathrm{C}_{2} \mathrm{H}_{2}$ como combustível, esta conta é $(2,5-1,1) \times(79,053 / 20,947)=$ 5,283 mol de $\mathrm{N}_{2}+$ Ar por mol de $\mathrm{C}_{2} \mathrm{H}_{2}$. Como nestas reações parte do $\mathrm{O}_{2}$ é fornecido pela mangueira e parte pelo ar atmosférico, a entrada de $\mathrm{N}_{2}+$ Ar na reação é oriunda exatamente da parte do ar atmosférico que vem junto aos $20,947 \%$ de $\mathrm{O}_{2}$. 
Ainda conforme este autor, o mol de fumos é calculado pela soma simples dos valores de $\mathrm{CO}_{2}$ e $\mathrm{H}_{2} \mathrm{O}$ produzidos. Exemplificando para $\mathrm{C}_{3} \mathrm{H}_{6}$ como combustível $\left(\mathrm{C}_{3} \mathrm{H}_{6}+\right.$ $4,5 \mathrm{O}_{2}=3 \mathrm{CO}_{2}+3 \mathrm{H}_{2} \mathrm{O}$ ) este valor é $3+3=6 \mathrm{~mol}$ de fumos por mol de $\mathrm{C}_{3} \mathrm{H}_{6}$.

ROSENQVIST $^{[57]}$ explica a limitação máxima da temperatura da chama devido ao início da dissociação dos gases formados: $\mathrm{CO}_{2}$ e $\mathrm{H}_{2} \mathrm{O}$, principalmente o primeiro. Esta dissociação, por ser endotérmica, acaba por determinar na prática um limite máximo de temperatura que pode ser obtido com a queima de hidrocarbonetos gasosos.

No gráfico da figura 4 também pode ser observado o deslocamento dos pontos máximos das curvas para a direita, exatamente na direção do maior consumo de $\mathrm{O}_{2}$, ou seja, quanto mais complexa a cadeia do hidrocarboneto, maior seu consumo de $\mathrm{O}_{2}$ e menor sua temperatura máxima de chama. Isto é perfeitamente justificável uma vez que uma cadeia de hidrocarboneto maior forma maior quantidade de $\mathrm{CO}_{2}$ e $\mathrm{H}_{2} \mathrm{O}$ como subprodutos e estes consumirão calor da reação química diminuindo assim sua temperatura máxima possível.

EKLUND $^{[52]}$ cita também a importância da temperatura da chama nos processos de soldagem e corte, uma vez que a maior temperatura faz com que a temperatura de fusão dos aços na soldagem e dos óxidos no corte sejam atingidas mais rapidamente, o que justificaria economicamente a escolha de combustíveis que produzam maior temperatura de chama. Ainda segundo este autor, existe uma forte correlação entre a temperatura e a velocidade da chama numa relação logarítmica onde a velocidade da chama aumenta muito para um pequeno incremento na temperatura da chama. O limite desta relação ocorre devido às reações de dissociação ocorrerem com cada vez maior freqüência com o aumento da temperatura, produzindo assim mais radicais livres na chama e ser necessário cada vez mais energia para a formação destes radicais

\subsubsection{PARÂMETROS E PRINCIPAIS VARIÁVEIS DO PROCESSO}

Vários são os aspectos que influem no corte oxi-combustível. Os principais fatores e sua influência são apresentados a seguir. 


\subsubsection{PRÉ-AQUECIMENTO DO METAL DE BASE ${ }^{[41,58]}$}

O oxicorte é um processo que uma vez iniciado, poder-se-ia teoricamente retirar a chama oxi-combustível que o processo geraria energia térmica suficiente para manter-se, através da reação exotérmica de oxidação do ferro. Na prática não é o que ocorre. As perdas de calor por condução para o restante da chapa acabam por diminuir a temperatura até um valor menor que a temperatura de oxidação viva do material, quando então o processo sofre a interrupção. No outro extremo, se a temperatura do pré-aquecimento estiver muito acima da temperatura de oxidação viva do material, estará próxima da temperatura de fusão e esta proximidade diminui a dureza e o limite de escoamento, produzindo em consequiência cortes com superfície irregular devido a fusão de partes da superfície de corte.

Ao se fazer o pré-aquecimento do metal de base, a potência da chama deve então se situar numa faixa ideal para fornecer energia suficiente entre os extremos acima comentados.

\subsubsection{ESPESSURA A SER CORTADA ${ }^{[60]}$}

A espessura a ser cortada embora não seja um parâmetro de trabalho propriamente dito, deve ser estudada individualmente por sua grande influência no funcionamento do processo.

Em função da espessura a ser cortada determina-se: o diâmetro do orifício de passagem de $\mathrm{O}_{2}$ no bico de corte, a pressão dos gases e em consequiência destes parâmetros, a velocidade de corte. Em linhas gerais, quanto maior a espessura, maior será o diâmetro do bico de corte necessário, maior a pressão e vazão de $\mathrm{O}_{2}$ necessária no jato de corte e menor a velocidade de corte.

\subsubsection{GRAU DE PUREZA DO MATERIAL A SER CORTADO ${ }^{[43,59-62]}$}

Por ser o oxicorte um processo de reação química, a presença de elementos de liga no aço apresenta características que podem interferir no corte. A seguir, são citados alguns 
dos elementos químicos que podem estar presentes nos aços, suas principais influências e as equações com as energias envolvidas:

Carbono: Teores acima de $0,35 \%$ podem provocar a têmpera superficial e, em consequiência, o aparecimento de trincas. Acima de $0,25 \%$ já é recomendado o uso de préaquecimento que, por diminuir a velocidade de resfriamento, minimiza a possibilidade da ocorrência da têmpera. As equações da formação dos óxidos de C são apresentadas a seguir:

$$
\begin{array}{lr}
C_{(s)}+1 / 2 O_{2_{(g)}} \Leftrightarrow C O_{(g)} & \Delta \mathrm{H}=-110,5 \mathrm{~kJ} / \mathrm{mol} \\
C_{(g)}+O_{2_{(g)}} \Leftrightarrow C O_{2_{(g)}} & \Delta \mathrm{H}=-393,5 \mathrm{~kJ} / \mathrm{mol}
\end{array}
$$

Cromo: Este elemento dificulta o corte por formar óxidos de cromo na superfície e impedir a reação de oxidação. Acima de $5 \%$ de Cr só é possível executar o corte por meio da adição de pó de ferro. As equações da formação dos óxidos de Cr são apresentadas a seguir:

$$
\begin{aligned}
& \mathrm{Cr}+1 / 2 \mathrm{O}_{(\mathrm{g})} \Leftrightarrow \mathrm{CrO}_{2_{(s)}} \quad \Delta \mathrm{H}=-598,0 \mathrm{~kJ} / \mathrm{mol} \mathrm{de} \mathrm{Cr} \\
& 2 \mathrm{Cr} r_{(s)}+1 \frac{1}{2} \mathrm{O}_{2_{(g)}} \Leftrightarrow \mathrm{Cr}_{2} \mathrm{O}_{3_{(s)}} \quad \Delta \mathrm{H}=-569,85 \mathrm{~kJ} / \mathrm{mol} \text { de } \mathrm{Cr} \\
& 3 \mathrm{Cr}_{(s)}+2 \mathrm{O}_{2_{(g)}} \Leftrightarrow \mathrm{Cr}_{3} \mathrm{O}_{4_{(s)}} \quad \Delta \mathrm{H}=-510,33 \mathrm{~kJ} / \mathrm{mol} \text { de } \mathrm{Cr}
\end{aligned}
$$

Níquel: Com baixos teores deste elemento (até 6\%) é possível a execução do corte desde que o aço não contenha elevados teores de carbono. As equações da formação dos óxidos de Ni são apresentadas a seguir:

$$
\begin{array}{rlrl}
2 N i_{(s)}+1 \frac{1}{2} \mathrm{O}_{2(s)} & \Leftrightarrow N i_{2} O_{3_{(s)}} & & \Delta \mathrm{H}=-244,75 \mathrm{~kJ} / \mathrm{mol} \text { de Ni } \\
N i_{(s)}+1 / 2 \mathrm{O}_{2_{(s)}} \Leftrightarrow N i O_{(s)} & \Delta \mathrm{H}=-244,11 \mathrm{~kJ} / \mathrm{mol} \text { de Ni }
\end{array}
$$

Cobre: Este é outro elemento que com baixos teores é possível a execução do corte. 
Em teores acima de $2 \%$ passa a ser necessária a adição de pó de ferro para a ocorrência do corte. As equações da formação dos óxidos de $\mathrm{Cu}$ são apresentadas a seguir:

$$
\begin{array}{cc}
\mathrm{Cu} u_{(s)}+1 / 2 \mathrm{O}_{(g)} \Leftrightarrow C O_{(s)} & \Delta \mathrm{H}=-156,75 \mathrm{~kJ} / \mathrm{mol} \text { de } \mathrm{Cu} \\
2 \mathrm{Cu} u_{(s)}+1 / 2 O_{2_{(g)}} \Leftrightarrow C u_{2} O_{(s)} & \Delta \mathrm{H}=-84,85 \mathrm{~kJ} / \mathrm{mol} \mathrm{de} \mathrm{Cu}
\end{array}
$$

Alumínio: Outro elemento que não interfere com o corte quando presente em baixos teores. Acima de $10 \%$ porém impossibilita a sua execução. A equação da formação do óxido de Al é apresentada a seguir:

$$
2 A l_{(s)}+31 / 2 O_{2_{(g)}} \Leftrightarrow A l_{2} O_{3_{(s)}} \quad \Delta \mathrm{H}=-821,995 \mathrm{~kJ} / \mathrm{mol} \text { de } \mathrm{Al}
$$

Manganês: Em baixos teores não causa efeitos no corte, porém em teores superiores a $14 \%$ torna necessária a adição de pós metálicos. As equações da formação dos óxidos de Mn são apresentadas a seguir:

$$
\begin{array}{crl}
M n_{(s)}+1 / 2 O_{2_{(g)}} \Leftrightarrow M n O_{(s)} & \Delta \mathrm{H}=-389,15 \mathrm{~kJ} / \mathrm{mol} \text { de Mn } \\
2 M n_{(g)}+31 / 2 O_{2_{(g)}} \Leftrightarrow M n_{2} O_{3_{(s)}} & \Delta \mathrm{H}=-486,34 \mathrm{~kJ} / \mathrm{mol} \text { de Mn } \\
3 M n_{(s)}+2 O_{2_{(g)}} \Leftrightarrow M n_{3} O_{4_{(s)}} & \Delta \mathrm{H}=-468,86 \mathrm{~kJ} / \mathrm{mol} \mathrm{de} \mathrm{Mn}
\end{array}
$$

Além das impurezas internas do material oriundas da composição química, há as oriundas de inclusões e segregações na chapa e as impurezas externas como pinturas, óleo ou graxa além da camadas de óxidos superficiais ${ }^{[63]}$, que também provocam irregularidades na face de corte durante a operação. 


\subsubsection{DIÂMETRO E TIPO DO BICO DE CORTE ${ }^{[64]}$}

Uma das escolhas mais importantes do processo é o bico de corte, pois é o condutor dos gases, e conseqüentemente responsável pela saída dos mesmos de maneira constante e sem turbulências. De acordo com o combustível, o bico deve ter uma forma construtiva diferente, visando aproveitar mais o calor de chama primária que o calor da chama secundária.

$\mathrm{O}$ canal de passagem do $\mathrm{O}_{2}$ pode também ser de diferentes formas ${ }^{[65]}$. Ele pode ter alteração no diâmetro ou não, e ainda ter uma cortina extra de $\mathrm{O}_{2}$, para proteger o jato de corte, visando aumentar sua concentração e com isso aumentar a velocidade de corte. As diferentes formas de bicos podem ser observadas na figura 5 .
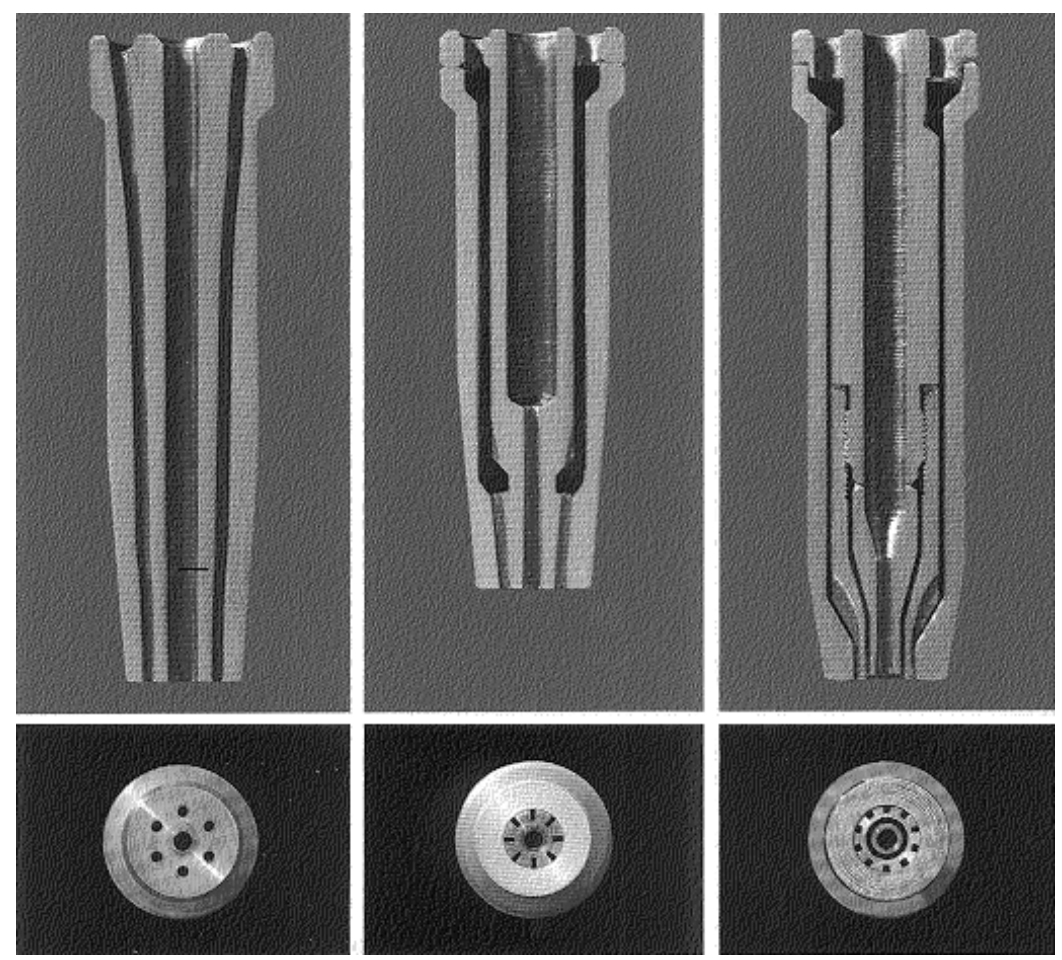

Figura 5 - Diferentes formas construtivas de bicos de corte para oxicorte ${ }^{[66]}$

Na figura 5 a esquerda é mostrado o bico com canal cilíndrico para o $\mathrm{O}_{2}$ de corte; no centro é visto o bico com uma redução no diâmetro para aumentar a velocidade de saída do jato de $\mathrm{O}_{2}$, conhecido como bico divergente, e na direita é apresentado o bico com a 
redução de diâmetro juntamente com a cortina adicional protetora para o $\mathrm{O}_{2}$ de corte, conhecido como bico cortina.

Os bicos ${ }^{[67]}$ podem também ser construídos em peça única ou em duas partes e são selecionados $^{[68]}$ prioritariamente em função da espessura da chapa a cortar $\mathrm{e}$ secundariamente de fatores como condições da superfície e composição química do material.

\subsubsection{PRESSÃO E VAZÃO DOS GASES UTILIZADOS ${ }^{[69]}$}

Estas variáveis estão relacionadas diretamente com a espessura a ser cortada, o tipo de bico, gás combustível escolhido e a velocidade de corte. Em linhas gerais, quanto maior a espessura a ser cortada, maiores devem ser a pressão e vazão dos gases.

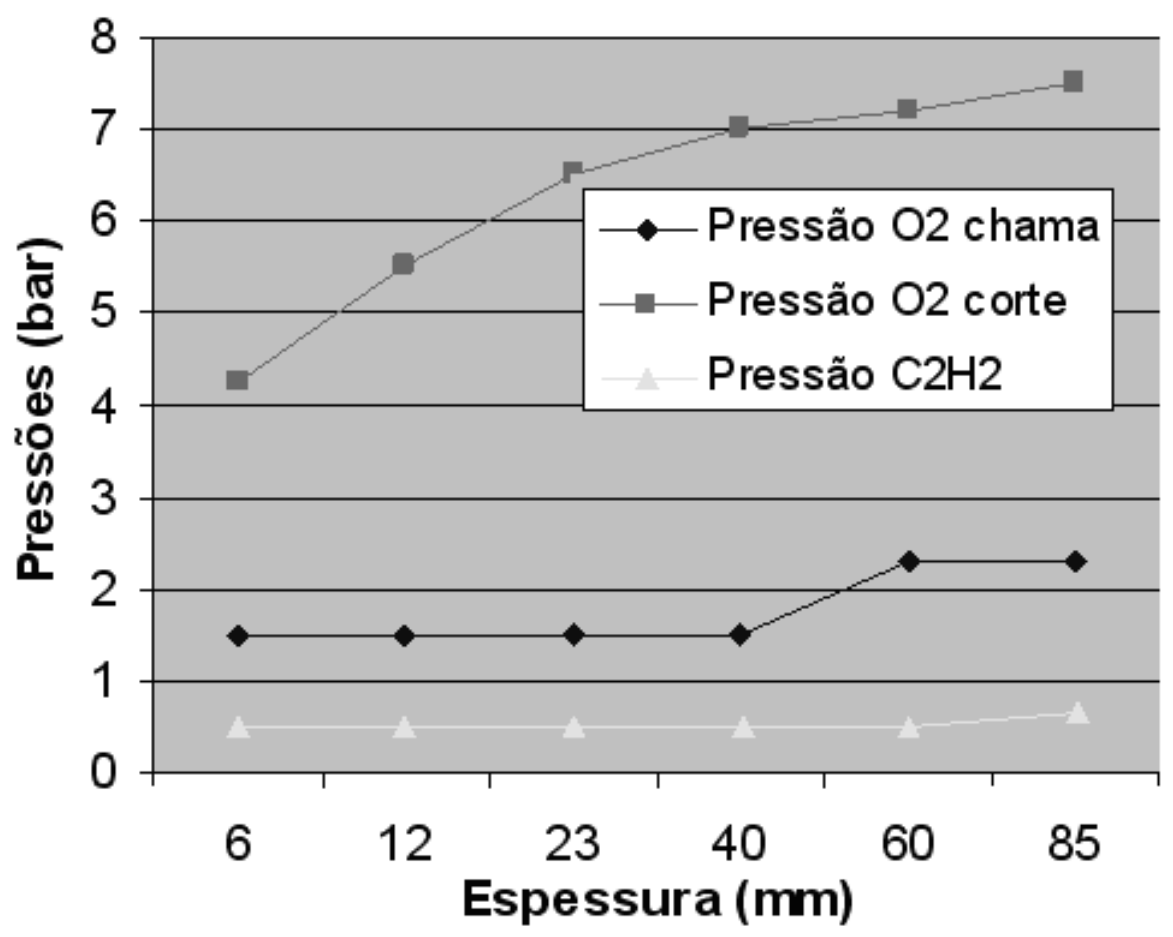

Figura 6 - Variação das pressões conforme a espessura para um maçarico misturador. Adaptado de ${ }^{[69]}$.

Considerando-se a largura do corte como função do diâmetro do orifício de $\mathrm{O}_{2}$, multiplicando-se a mesma pelo comprimento linear a ser cortado e depois pela espessura, chega-se facilmente ao volume a ser oxidado. 
Conhecendo-se as reações químicas envolvidas, é possível fazer um balanço de massa e determinar as vazões teóricas necessárias. Na prática porém os operadores seguem tabelas pré-estabelecidas para as regulagens operando o equipamento, freqüentemente, com vazões e pressões acima do necessário, que por sua vez compensam bicos sujos, danificados, e demais obstruções à passagem dos gases.

\subsubsection{VELOCIDADE DE AVANÇO DO MAÇARICO ${ }^{[70]}$}

A velocidade de avanço deve ser regulada em função dos outros parâmetros, e será ideal quando ${ }^{[65,68,70]}$ o deslocamento do maçarico acompanhar a velocidade da etapa controladora da reação seja esta controlada pela velocidade da reação em si, pela difusão do calor para a chapa, pela velocidade de expulsão dos produtos reagidos pelo jato de $\mathrm{O}_{2}$ ou pela concentração do $\mathrm{O}_{2}$ de corte na espessura em questão. Quando estes parâmetros não estão em equilíbrio, ocorre uma das seguintes situações:

(a) Em velocidades de deslocamento do maçarico muito altas, o processo interrompe-se, pois o jato de $\mathrm{O}_{2}$ começa a ser direcionado para uma superfície ainda não suficientemente aquecida para iniciar a oxidação do ferro do aço. Esta, sem o calor da reação exotérmica é resfriada pelo jato do $\mathrm{O}_{2}$ de corte que é assim interrompido.

(b) Em velocidades muito baixas, para além da oxidação há aquecimento suficiente para a fusão das bordas, o que produz um pior acabamento da superfície e adesão da escória por fusão desta na extremidade inferior.

Além deste aspecto, a velocidade também tem relação direta com a geração de calor no processo, e em conseqüência disto, afeta a temperatura do corte e a composição da escória de corte. A referência ${ }^{[48]}$ mostra que o aumento da velocidade de corte causa aumento nos teores de $\mathrm{FeO}$ e $\mathrm{Fe}$ metálico e decréscimo no teor de $\mathrm{Fe}_{2} \mathrm{O}_{3}$ da escória. Este gráfico é apresentado na figura 7. É interessante observar que este gráfico não leva em conta a presença de magnetita na escória de corte. 
A figura 7 mostra também que o teor de ferro na escória aumenta com o aumento da velocidade de corte. Para uma velocidade de corte de $400 \mathrm{~mm} / \mathrm{min}$ a porcentagem de Fe na escoria é de aproximadamente $18 \%$.

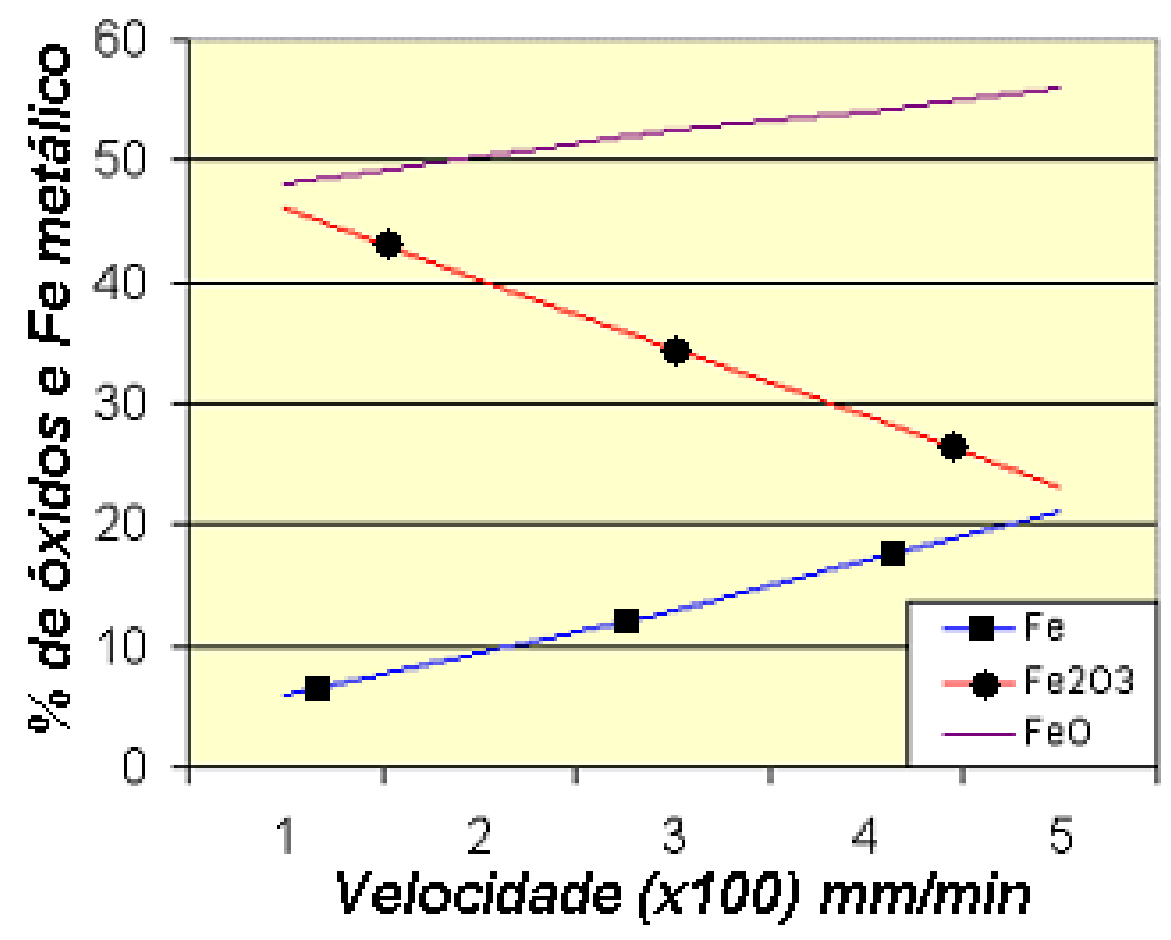

Figura 7 - Variação da composição química da escória com a velocidade de corte ${ }^{[48]}$

Pode-se afirmar que a velocidade de deslocamento do maçarico em relação à peça é uma das variáveis mais importantes para a qualidade da operação, e acaba por ser também diretamente responsável pelo custo, pois determinará o tempo empregado na produção de uma determinada peça.

\subsubsection{GRAU DE CONCENTRAÇÃO DO OXIGÊNIO DE CORTE}

Por ser o processo uma reação química do $\mathrm{O}_{2}$ principalmente com o ferro do aço, a concentração do $\mathrm{O}_{2}$ é de fundamental importância nos aspectos termodinâmicos e cinéticos do processo oxicorte. O oxigênio industrial apresenta uma concentração mínima de $99,5 \%{ }^{[48]}$. 
Considerando-se condições normais de trabalho como: ausência de contaminantes na tubulação, nos cilindros ou nos tanques de armazenamento do gás, as impurezas do $\mathrm{O}_{2}$ normalmente serão nitrogênio e argônio, que são os demais componentes do ar atmosférico, matéria prima de onde o $\mathrm{O}_{2}$ é retirado. É importante destacar que o jato do $\mathrm{O}_{2}$ de corte assim que sai do bico de corte já entra em contato com o ar e a partir deste instante apesar de sua velocidade, já inicia sua contaminação. Esta contaminação começa com o contato com o ar atmosférico e, em seguida, com os gases resultantes das reações químicas que estão ocorrendo no corte, como a oxidação do carbono do aço.

Como o processo é dinâmico, com o jato de corte deslocando-se em relação à peça, na parte posterior da camada limite do jato (a parte da frente do corte) há o contato diretamente com a peça e a utilização preponderante do oxigênio é para a reação química, enquanto na parte anterior à função mais importante do $\mathrm{O}_{2}$ é a expulsão do jato de óxidos formados. A figura 8 mostra esquematicamente o percurso do jato de corte através da chapa.

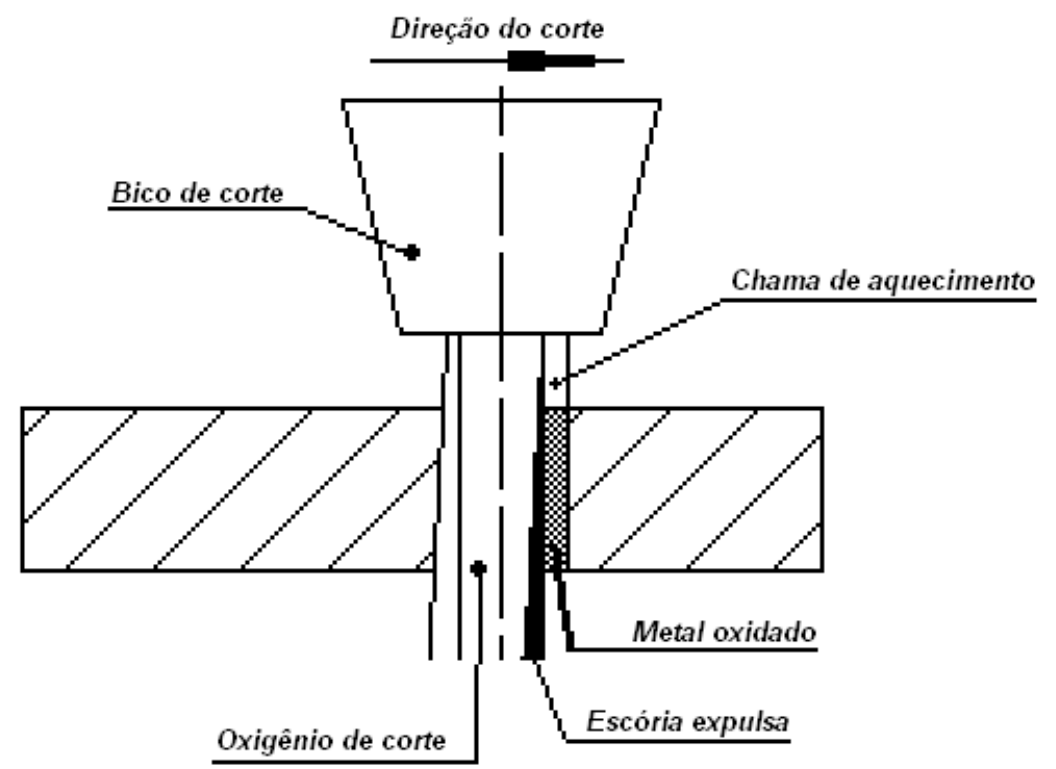

Figura 8 - Percurso do jato de $\mathrm{O}_{2}$ de corte através da chapa ${ }^{[71]}$.

Por o aço conter carbono o oxigênio oxida-o formando monóxido de carbono que contribui para reduzir ainda mais a concentração do $\mathrm{O}_{2}$, e esta contaminação será tanto pior 
quanto maior for a espessura da chapa. Assim, tem-se na parte superior da chapa a reação química com um grau de concentração de $\mathrm{O}_{2}$ e na parte inferior com a concentração substancialmente menor. Como a concentração dos reagentes é um dos aspectos que alteram a cinética de uma reação, é natural que a velocidade desta, e conseqüentemente a velocidade da operação de corte, seja diferente em ambas as extremidades da chapa.

Esta diferença de velocidades é uma das causas do desvio popularmente conhecido como "atraso", que é identificado com a letra "e" na figura 9. O trabalho "Facts about oxy cutting" ${ }^{, 48]}$ mostra que, em uma chapa de aço carbono com a espessura de $20 \mathrm{~mm}$ e com a velocidade de corte constante no valor de $400 \mathrm{~mm} / \mathrm{min}$, o atraso varia linearmente de acordo com o grau de concentração do $\mathrm{O}_{2}$ utilizado para corte. $\mathrm{O}$ resultado deste trabalho é mostrado na figura 9.
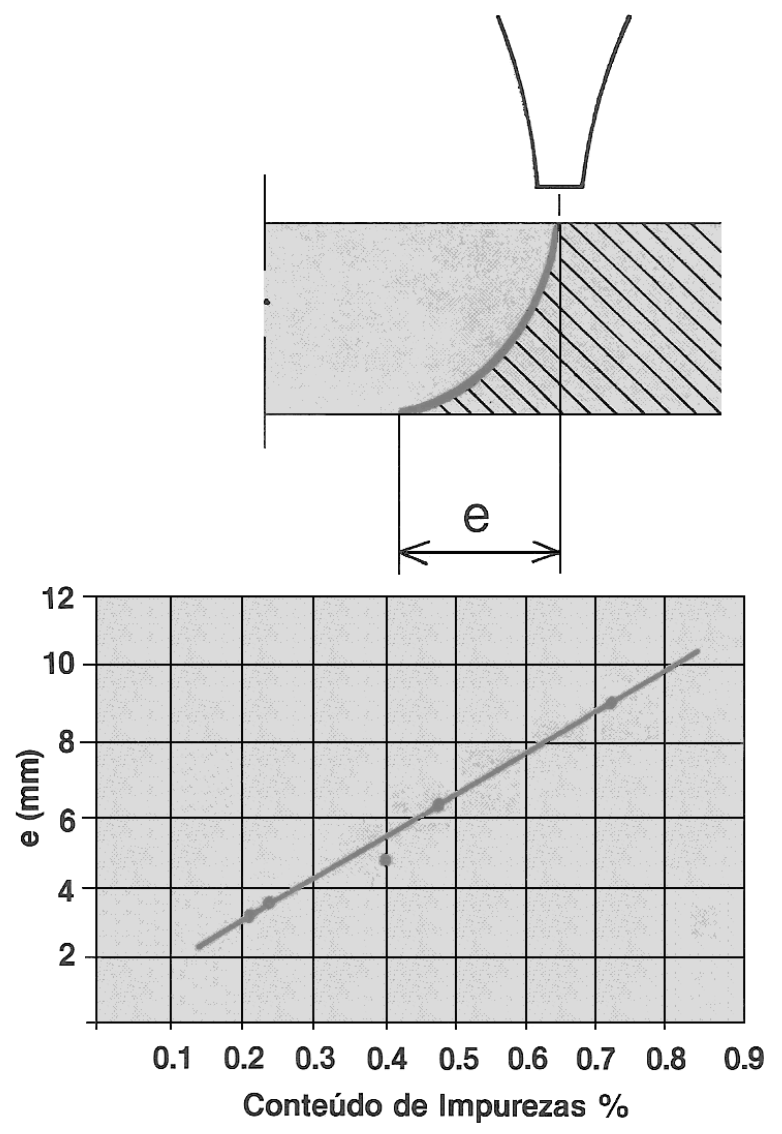

Figura 9 - Influência do teor de impurezas no desvio do corte ${ }^{[48]}$ 
No trabalho de MORRIS ${ }^{[72]}$ é apresentado um interessante estudo sobre a relação do atraso com a qualidade do corte e consumo de $\mathrm{O}_{2}$ do processo, enquanto que GRANJON e ROSEMBERG $^{[73]}$ citam que a concentração do $\mathrm{O}_{2}$ na faixa de $95 \%$ ainda seria possível de utilizar para a soldagem, mas não para o oxicorte.

\subsubsection{DEFEITOS E DESCONTINUIDADES ${ }^{[11,74-77]}$}

Em um corte de boa qualidade a superfície é lisa, regular e as linhas resultantes na superfície da peça cortada são quase verticais. A escória, aderida na parte inferior do corte pode facilmente ser removida. Algumas vezes porém, o processo apresenta algumas irregularidades. As tabelas 3 e 4 mostram os principais defeitos do processo e suas causas mais comuns:

TABELA 3 - DEFEITOS E DESCONTINUIDADES NO OXICORTE $1^{[41,78]}$

\begin{tabular}{|c|c|c|}
\hline Ocorrência & Ilustração & Provável Causa \\
\hline $\begin{array}{l}\text { Goivagem na borda } \\
\text { superior }\end{array}$ & 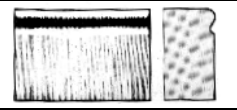 & $\begin{array}{l}\text { Velocidade de corte excessiva; } \\
\text { Bico sujo ou danificado. }\end{array}$ \\
\hline $\begin{array}{l}\text { Goivagem na borda } \\
\text { inferior }\end{array}$ & & $\begin{array}{l}\text { Velocidade de corte excessiva; } \\
\text { Bico sujo ou danificado. }\end{array}$ \\
\hline $\begin{array}{l}\text { Superfície de corte } \\
\text { côncava }\end{array}$ & 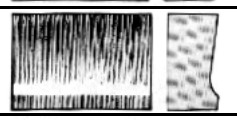 & $\begin{array}{l}\text { Velocidade de corte excessiva; Bico sujo ou danificado; } \\
\text { Baixa pressão de } \mathrm{O}_{2} \text { de corte. }\end{array}$ \\
\hline $\begin{array}{l}\text { Superfície de corte } \\
\text { convexa }\end{array}$ & & $\begin{array}{l}\text { Velocidade de corte excessiva; Bico sujo ou danificado; } \\
\text { Baixa pressão de } \mathrm{O}_{2} \text { de corte. }\end{array}$ \\
\hline $\begin{array}{l}\text { Fusão da borda } \\
\text { superior }\end{array}$ & will & $\begin{array}{l}\text { Baixa velocidade de corte; Pouca ou muita distância do } \\
\text { bico à peça; Bico muito grande; } \\
\text { Chama de pré-aquecimento excessiva. }\end{array}$ \\
\hline $\begin{array}{l}\text { Gotas fundidas na } \\
\text { borda superior }\end{array}$ & 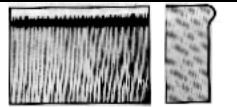 & $\begin{array}{l}\text { Pouca distância do bico-peça; Chama de pré-aquecimento } \\
\text { excessiva; Carepas ou ferrugem na superfície da chapa. }\end{array}$ \\
\hline $\begin{array}{l}\text { Borda superior } \\
\text { goivada com escória }\end{array}$ & 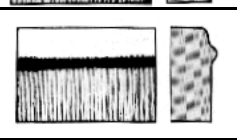 & $\begin{array}{l}\text { Distância excessiva do bico à peça; Chama de pré- } \\
\text { aquecimento em excesso; Pressão do } \mathrm{O}_{2} \text { de corte } \\
\text { excessivamente alta. }\end{array}$ \\
\hline
\end{tabular}


TABELA 4 - DEFEITOS E DESCONTINUIDADES NO OXICORTE $2^{[41,78]}$

\begin{tabular}{|c|c|c|}
\hline Ocorrência & Ilustracão & Provável Causa \\
\hline $\begin{array}{l}\text { Borda inferior } \\
\text { arredondada }\end{array}$ & & $\begin{array}{l}\text { Pressão do } \mathrm{O}_{2} \text { de corte excessivamente alta; Bico sujo } \\
\text { ou danificado; Velocidade de corte excessiva }\end{array}$ \\
\hline $\begin{array}{lr}\text { Entalhe } & \text { na } \\
\text { superfície inferior } \\
\text { docorte }\end{array}$ & Bind & Bico sujo ou danificado; Baixa velocidade de corte \\
\hline $\begin{array}{l}\text { Ondulações } \\
\text { profundas }\end{array}$ & & $\begin{array}{l}\text { Alta velocidade de corte; Velocidade de corte desigual; } \\
\text { Pouca distância bico/peça; Chama de pré-aquecimento } \\
\text { muito forte }\end{array}$ \\
\hline $\begin{array}{l}\text { Grandes } \\
\text { ondulações } \\
\text { desiguais }\end{array}$ & & $\begin{array}{l}\text { Alta velocidade de corte; Velocidade de corte desigual; } \\
\text { Chama de pré-aquecimento muito fraca }\end{array}$ \\
\hline Corte incompleto & & $\begin{array}{l}\text { Velocidade de corte excessiva; Distância bico/peça } \\
\text { muito grande; Bico sujo ou danificado; Chama de pré- } \\
\text { aquecimento muito fraca; Retrocesso no bico e } \\
\text { maçarico; Carepas ou ferrugem na superfície da chapa; } \\
\text { Chapa com inclusão de escória }\end{array}$ \\
\hline $\begin{array}{l}\text { Escória aderente na } \\
\text { borda inferior }\end{array}$ & 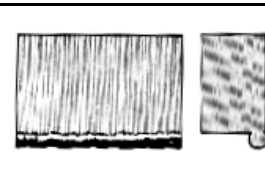 & $\begin{array}{l}\text { Carepas ou ferrugem na superfície; Bico muito pequeno; } \\
\text { Chama de pré-aquecimento muito fraca; Velocidade de } \\
\text { corte incorreta; Distância excessiva do bico/peça; Baixa } \\
\text { pressão do } \mathrm{O}_{2} \text { de corte }\end{array}$ \\
\hline
\end{tabular}

\subsubsection{A PRODUTIVIDADE E A RENTABILIDADE DO PROCESSO ${ }^{[79,80-82]}$}

Diversos fatores afetam a produtividade e a rentabilidade do processo. Os tópicos listados a seguir podem ser considerados os mais significativos.

a) Concentração do oxigênio. Como já citado em 2.2.3.7 nas referências ${ }^{[48,80]}$, a concentração do $\mathrm{O}_{2}$ deve ser maior que $99,5 \%$. Uma redução de $0,5 \%$ na concentração reduz a velocidade de corte em até $10 \%$. A figura 10 ilustra este fato apresentando a relação do conteúdo de impurezas no oxigênio de corte e sua influência na velocidade de corte, mantidos os demais parâmetros constantes. 


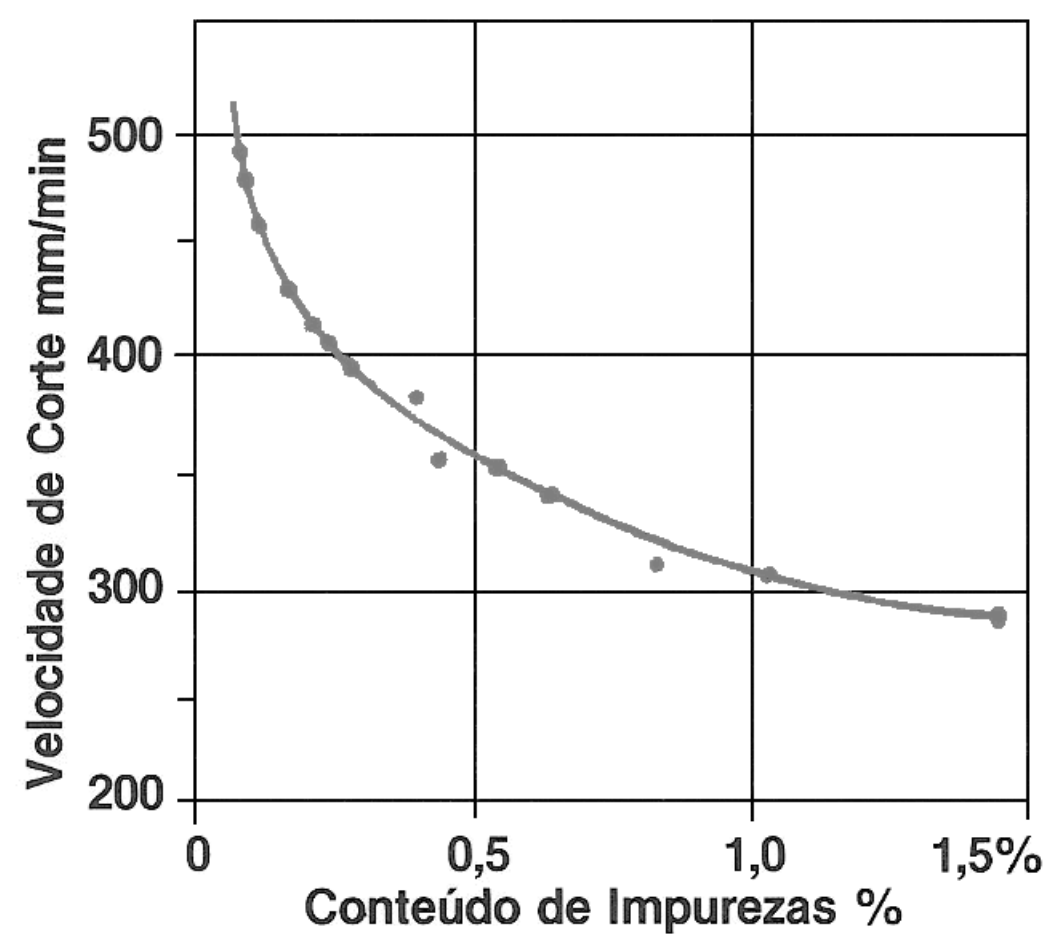

Figura 10 - Influência do teor de impurezas e velocidade de corte ${ }^{[48]}$

b) Gás combustível utilizado. Além dos aspectos discutidos em 2.2.2.1, os diversos combustíveis disponíveis no mercado podem ser separados por velocidades de chama. Visando minimizar os custos de corte, $\mathrm{KRAMM}^{[80]}$ recomenda a utilização de combustíveis com altas velocidades de combustão (como o acetileno) em chapas até $450 \mathrm{~mm}$ e combustíveis com baixas velocidades de combustão (como o propano e propileno) para chapas acima de $450 \mathrm{~mm}$ de espessura. BRANDI et al ${ }^{[79]}$ citam que a escolha do combustível altera o consumo de $\mathrm{O}_{2}$, uma vez que diferentes gases apresentam diferentes proporções estequiométricas de $\mathrm{O}_{2}$ para sua combustão completa. Tanto as velocidades de combustão como a estequeometria das reações foram informados na tabela 2.

c) Simultaneidade da operação. KRAMM $^{[80]}$ mostra em seu trabalho que um metro linear cortado com um maçarico tem um valor referência de custo igual a 155. Apenas adicionando o segundo maçarico no equipamento, este valor cai para 95. Com 8 maçaricos este valor cai para 48. Além da duplicação de maçaricos no mesmo dispositivo de movimentação, a simultaneidade da operação é possível nas formas de: (a) sobreposição de chapas para serem cortadas com o mesmo maçarico ${ }^{[83]}$, técnica que apresenta vantagens do 
ponto de vista de economia mas requer limpeza e bom acabamento superficial para que as chapas sobreponham-se como uma única, e (b) a utilização de um dispositivo conhecido como duplicador de bicos. A figura 11 ilustra as diferentes formas de simultaneidade da operação.
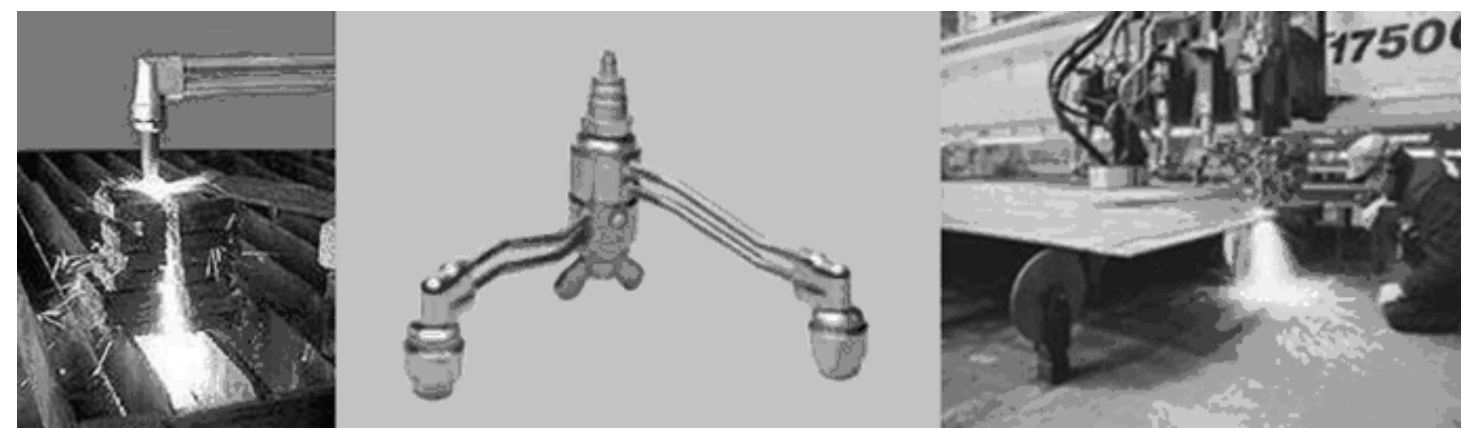

Figura 11 - Simultaneidade da operação, da esquerda para a direita: chapas sobrepostas, dispositivo duplicador de bico e diversos maçaricos no mesmo dispositivo de movimentação.

Também no trabalho de $\mathrm{KRAMM}^{[80]}$ é apresentado um interessante estudo onde, partindo de valores de gases e mão de obra médios de mercado, é verificado o custo de cada peça produzida na medida que o processo vai ganhando mais um maçarico no mesmo dispositivo de deslocamento. Com base neste estudo foram construídos os gráficos das figuras 12 e 13.

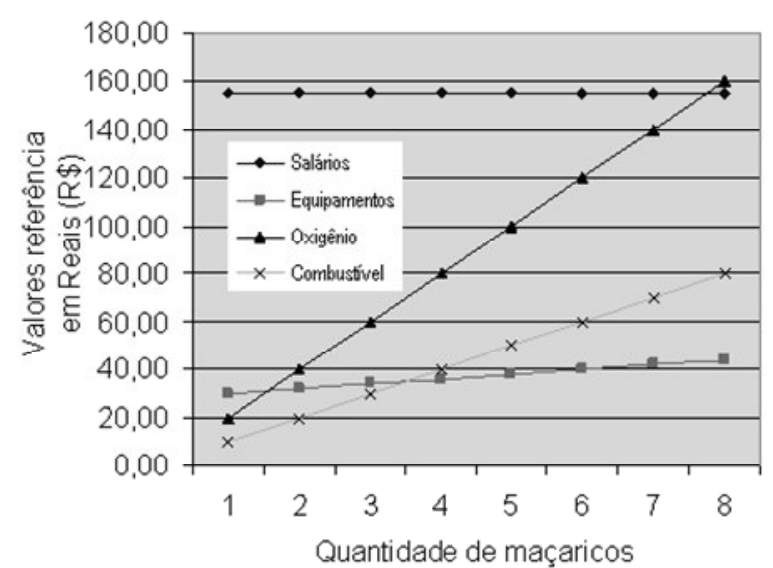

Figura 12 - Gastos com insumos no processo conforme o numero de maçaricos

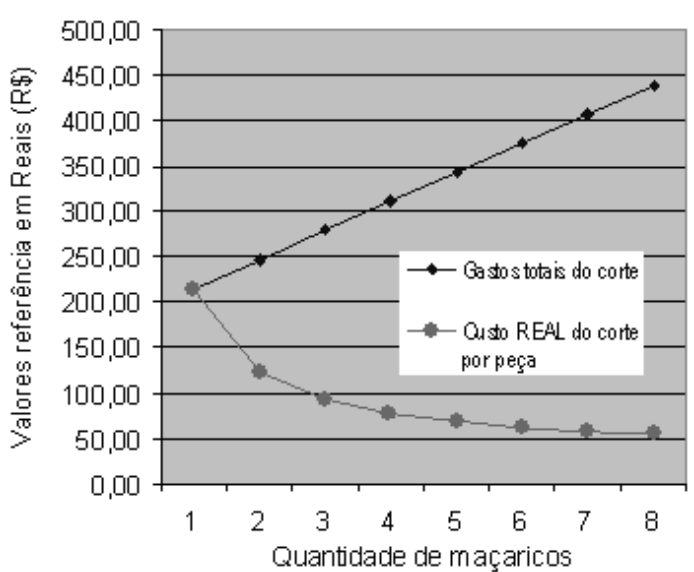

Figura 13 - Influência da simultaneidade no custo da operação 
d) Treinamento dos operadores. O operador é o elo mais importante para o funcionamento do processo com a máxima rentabilidade. Um operador mal treinado que, por exemplo, não substitui um bico de corte por um de menor diâmetro quando corta uma chapa de menor espessura, pode pensar que ganha tempo por não parar, quando na verdade corta uma chapa fina com o consumo de gás necessário para o corte de uma chapa grossa. Por outro lado, quando a necessidade crítica é a velocidade da operação, o conhecimento do fato de que um bico indicado para uma chapa de espessura maior pode cortar com maior velocidade é também interessante.

\subsection{FLUXO DE CALOR E REAÇÕES QUÍMICAS ENVOLVIDAS}

O oxicorte é um processo de seccionamento de ligas ferrosas pela combustão localizada devido à ação de um jato de $\mathrm{O}_{2}$, que age sobre um ponto pré-aquecido por uma chama oxi-combustível. Além de cortar, o aquecimento causa diversos outros efeitos na região adjacente ao corte, uma vez que esta é submetida a um ciclo de aquecimento e resfriamento, conhecido por ciclo térmico.

Conforme $\mathrm{KOU}^{[84]}$ e $\mathrm{GRONG}^{[85]}$, em uma região aquecida tanto para soldagem quanto para corte e suas adjacências, é possível a ocorrência de: transformações de fase do material, reações químicas, crescimento do tamanho de grão, dissolução de precipitados e difusão.

Como todos estes processos podem alterar substancialmente a estrutura do material, o estudo da variação da temperatura em função do tempo e da distância vem a ser a ferramenta que permite determinar, para cada região, quais dos fenômenos citados podem ocorrer, como ocorrem e quais as influências e alterações que estes produzirão nas propriedades do material em questão.

\subsubsection{CONSIDERAÇÕES INICIAIS SOBRE FLUXO DE CALOR ${ }^{[86]}$}

Quando aquecemos um ponto específico de um material para o processo de oxicorte, as regiões vizinhas a este ponto são submetidas a um aumento de temperatura por 
condução de calor, causando um gradiente térmico que apresenta os seguintes limites: (a) a maior temperatura da reação do oxicorte e (b) a temperatura ambiente. Exemplificando estes dois extremos com as cores vermelho e azul, temos o esquema de um gradiente térmico como pode ser visto na figura 14 .

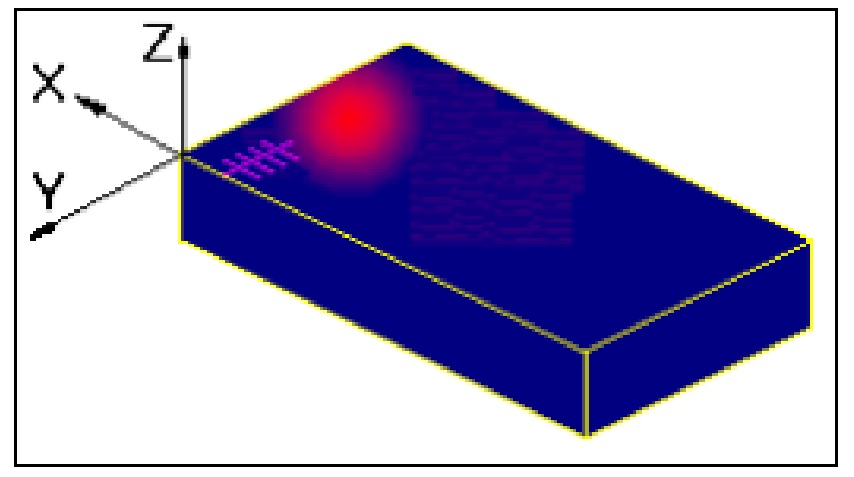

Figura 14 - Gradiente térmico de uma peça aquecida ${ }^{[87]}$.

Quando colocamos as direções " $x$ " e " $y$ " da peça aquecida e assumimos como o eixo "z" os valores máximos de temperatura atingidos temos um mapa térmico espacial como o apresentado na figura 15.

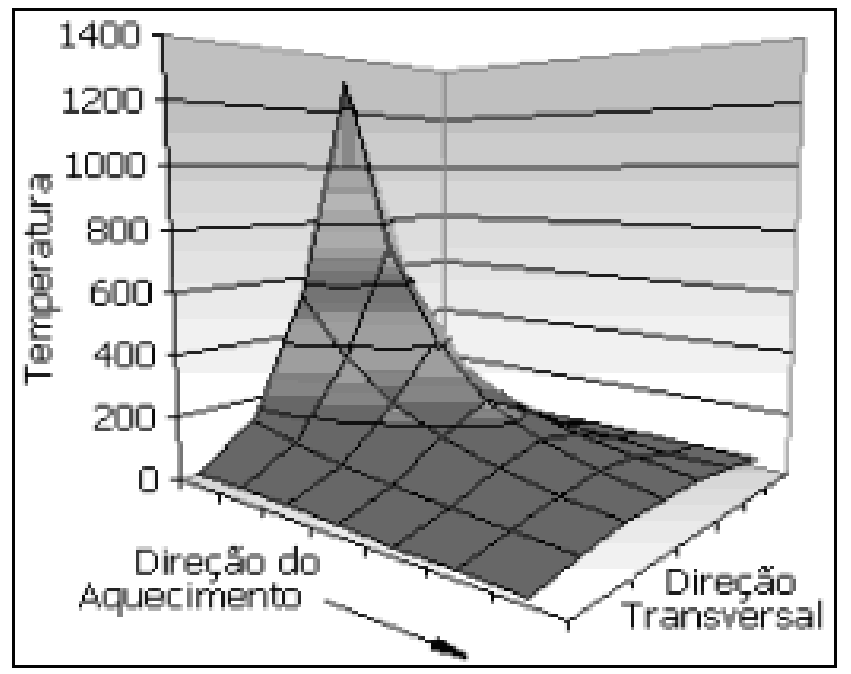

Figura 15 - Mapa térmico espacial ${ }^{[87]}$

Um mapa espacial como o apresentado na figura 15 é de pouca utilidade, uma vez que ele apenas indica, para cada ponto $(\mathrm{x}, \mathrm{y})$ a temperatura máxima atingida e não indica para cada ponto, o tempo que uma dada temperatura foi atingida, ou seja, o tempo que cada ponto foi mantido em cada temperatura. 


\subsubsection{CICLOS TÉRMICOS E REPARTIÇÃO TÉRMICA}

Como um mapa espacial não fornece o tempo de permanência de cada ponto em cada temperatura, um estudo adequado deve ser feito individualmente para cada ponto com suas coordenadas $\mathrm{x}, \mathrm{y}, \mathrm{z}$ em função do tempo. Para cada ponto é então traçada uma curva tempo x temperatura, e a cada uma destas curvas denomina-se ciclo térmico. Quando juntamos vários ciclos térmicos em um único gráfico, temos uma repartição térmica da peça objeto do estudo, que é formada pela reta traçada entre os pontos de máximo das curvas dos ciclos térmicos. A figura 16 apresenta ciclos térmicos e repartição térmica esquemáticos para os pontos de aquecimento da figura 14. O gráfico do ciclo térmico deve apresentar sempre a localização espacial $(\mathrm{x}, \mathrm{y}, \mathrm{z})$ do ponto estudado, como mostra a figura a seguir:

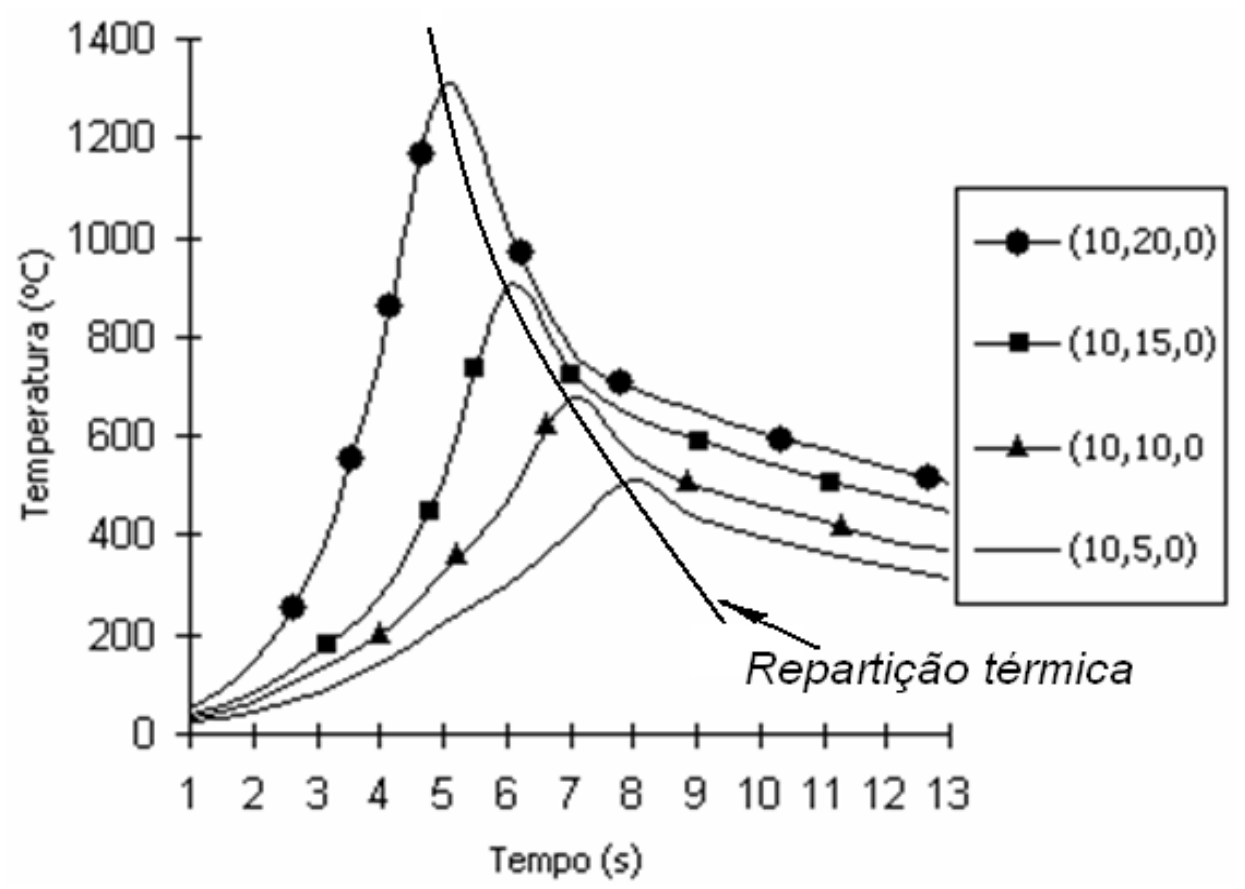

Figura 16 - Ciclos Térmicos e Repartição Térmica ${ }^{[87]}$

\subsubsection{CALOR E RENDIMENTO TÉRMICO}

Uma fonte de calor não consegue transformar todo calor produzido em calor aplicado $^{[88]}$. De acordo com Christensen et alli ${ }^{[89]}$, existem diversas perdas de calor naturais do processo, e em processos oxi-combustíveis podemos citar como exemplo, entre outros, o 
aquecimento de bicos e maçaricos. A relação entre o calor gerado e o calor transferido é expressa pela letra $\eta$ denominada rendimento térmico, e é apresentada na equação 24.

$$
\eta=\frac{\text { e transferida }}{\text { e gerada }}
$$

O rendimento térmico varia em função do processo. Para um processo oxiacetilênico, este valor é citado por $\mathrm{KOU}^{[84]}$ e $\mathrm{MACHADO}^{[86]}$ como sendo $(0,52 \pm 0,27)$. A variação tão alta, em relação ao valor médio, deve-se ao fato que uma chama pode ser regulada num vasto espectro desde a chama oxidante, passando pela neutra e atingindo por fim a chama carburante, com diferentes temperaturas. As diferentes formas de se regular uma chama são as apresentadas na figura $17^{[69]}$.

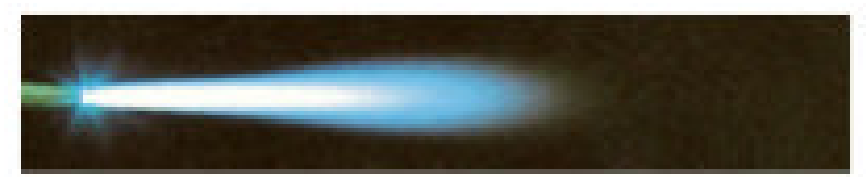

Chama carburamte

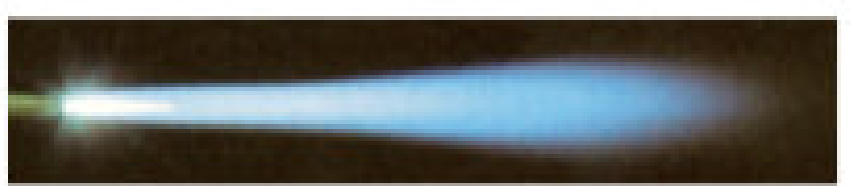

Chama neutra

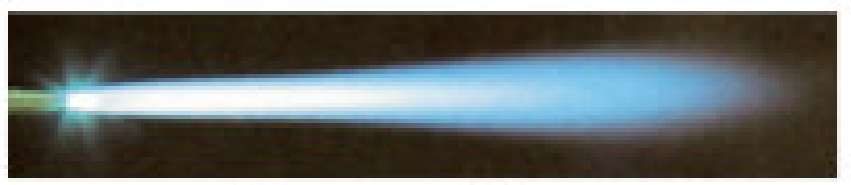

\section{Chama oxidante}

Figura 17 - Tipos de chamas

Em uma chama oxi-acetilênica neutra, que é a usual em processo de aquecimento para corte, $\mathrm{KOU}^{[84]}$, mostra que a potência pode ser calculada através da equação a seguir. 


$$
Q=\frac{\eta \times 48000 \times V}{3600} \Rightarrow Q=13,33 \times V x \eta
$$

Onde:

$\mathrm{Q}=$ potência calorífica em Watt

$\eta=$ rendimento $(0,52 \pm 0,27)$

$48000=$ calor de combustão do acetileno em $\mathrm{J} / 1$

$\mathrm{V}=$ vazão de acetileno $1 / \mathrm{h}$

$3600=$ fator de conversão de horas para segundos

\subsubsection{CÁLCULO DA DISTRIBUIÇÃO DA TEMPERATURA}

A distribuição da temperatura pode ser obtida pelas equações de fluxo de calor estudadas por diversos autores ${ }^{[1,90]}$. Para isto, é necessário que se faça as seguintes considerações $^{[84,86,91]}$

a - Não existir fontes nem sumidouros de calor, por ex. não considerar o calor latente de fusão.

$\mathrm{b}-$ As propriedades físicas do material serem constantes.

c - A velocidade e a potência da fonte serem constantes.

d - O efeito Joule, a dissipação viscosa e a convecção serem desprezadas.

e - O regime analisado ser quase estacionário ${ }^{[92]}$.

Para se considerar o regime quase-estacionário transfere-se a origem das coordenadas da chapa para o maçarico. Com isso, a coordenada X é então substituída pela coordenada móvel $\xi$.

Assim, assume-se então o valor $\xi$ conforme a equação a seguir:

$$
\xi=X-v t
$$


onde:

$\xi=$ Coordenada móvel da dimensão do eixo "x"

$\mathrm{v}=$ Velocidade de soldagem $\mathrm{em} \mathrm{mm} / \mathrm{s}$

$\mathrm{t}=$ Tempo em $\mathrm{s}$

De posse destas considerações, ROSENTHAL ${ }^{[1]}$ desenvolveu então a equação do fluxo de calor.

$$
-\frac{v}{a} \frac{\partial T}{\partial \xi}=a\left[\frac{\partial^{2} T}{\partial \xi^{2}}+\frac{\partial^{2} T}{\partial y^{2}}+\frac{\partial^{2} T}{\partial z^{2}}\right]
$$

Em seguida, propôs soluções para esta equação, diferenciando-a para chapas finas, médias e grossas. Numa chapa grossa, a temperatura de um ponto situado na coordenada móvel R descrita como na equação 28 :

$$
R=\sqrt{\xi^{2}+y^{2}+z^{2}}
$$

Pode ser calculada conforme a equação 29:

$$
T-T_{0}=\frac{Q_{p}}{2 \pi k} e^{-k v \xi} \frac{e^{-k v R}}{R}
$$

Onde:

$\mathrm{T}=$ Temperatura a ser calculada $\left({ }^{\circ} \mathrm{C}\right)$

$\mathrm{T}_{\mathrm{o}}=$ Temperatura Ambiente $\left({ }^{\circ} \mathrm{C}\right)$

$\mathrm{Q}_{\mathrm{p}}=$ potência transmitida para o cordão de solda $(\mathrm{W})$

$\mathrm{k}=$ Condutividade Térmica $\left(\mathrm{W} / \mathrm{mm}^{\circ} \mathrm{C}\right)$

$\mathrm{v}=$ Velocidade de soldagem $(\mathrm{mm} / \mathrm{s})$

$\xi$ = Coordenada móvel na direção da soldagem (mm)

$\mathrm{R}=\left(\xi^{2}+\mathrm{y}^{2}+\mathrm{z}^{2}\right)^{(1 / 2)}$

(Obs. Os itens $\mathrm{Q}_{\mathrm{p}} \mathrm{e} \xi$ estão com o termo "soldagem" uma vez que esta equação foi desenvolvida inicialmente para a soldagem sendo depois adaptada ao oxicorte.) 
De posse desta equação, é então possível calcular o ciclo térmico do material, o que vem a ser uma informação mais importante que um simples mapa espacial de temperatura, uma vez que fornece a informação do tempo que cada ponto esteve em cada temperatura estudada. O gráfico com diversos ciclos térmicos é o já apresentado na figura 16.

Alguns autores fizeram ajustes e correções nas fórmulas iniciais de Rosenthal visando aprimorá-la, cabendo citar os trabalhos de LODOÑO e BRANDI ${ }^{[91]}$ onde é feita uma correção para soldagem multi passe e o de RAMALHO e BRANDI ${ }^{[92]}$ onde são apontados cuidados para a utilização da metodologia de Rosenthal no processo oxicorte.

\subsubsection{PARTICULARIDADES TÉRMICAS NO OXICORTE}

O processo oxicorte, diferentemente dos processos de soldagem, que são a base do estudo do fluxo de calor apresentado até aqui, apresenta um "nascedouro" de calor no meio da seção cortada.

O processo gera calor por reação química exotérmica, ou seja, analisando-se a espessura "z", cada elemento "dz" pode ser considerado como uma minúscula fonte de calor. Com isto, a primeira premissa considerada, sobre a não existência de fontes de calor no interior da peça, passa a ser falsa, necessitando ajustes no modelo apresentado.

ROSENTHAL ${ }^{[1]}$ faz uma adaptação a este modelo visando contornar este problema, assumindo o maçarico como uma fonte pontual também no sentido da espessura. Assim, o ponto R anteriormente utilizado passa a ser R' para cada ponto no sentido da espessura z', conforme é apresentado na equação 30 .

$$
R^{\prime}=\sqrt{\xi^{2}+y^{2}+\left(z-z^{\prime}\right)^{2}}
$$

Com isso, são tomados os diversos $\mathrm{R}^{\prime}$ criados para cada ponto no sentido da espessura na equação 30 e aplicados na equação 29, possibilitando o cálculo da temperatura em um dado ponto, como é apresentado na equação 31. 


$$
T-T_{0}=\frac{q_{p}}{4 \pi k_{s}} e^{-k v \xi} \frac{e^{-k v R^{\prime}}}{R^{\prime}}
$$

Desta forma o "q" inicial, ou seja, a energia transmitida passa a ser um novo "q", agora gerado em função da variação de espessura, como é apresentado na equação 32.

$$
q \times \Delta z^{\prime}
$$

Com isto, a temperatura será incrementada acima da temperatura inicial na proporção $\Delta=\left(\mathrm{T}-\mathrm{T}_{0}\right)$. A temperatura do ponto $\mathrm{R}^{\prime}$ terá então uma variação conforme mostra a equação 33 .

$$
\Delta\left(t-t_{0}\right)=\frac{q \Delta z^{\prime}}{4 \pi k_{s}} e^{-k v \xi} \frac{e^{-k v R^{\prime}}}{R^{\prime}}
$$

Assim o total do incremento da temperatura no processo oxicorte pode ser então calculado através da integração em toda a dimensão Z, como é apresentado na equação 34 .

$$
t-t_{0}=\int \frac{q d z^{\prime}}{4 \pi k_{s}} e^{-k v \xi} \frac{-e^{k v R^{\prime}}}{R}
$$

ROSENTHAL ${ }^{[1]}$ cita que um caso particular dessa integração para q constante seria:

$$
t-t_{0}=\frac{q}{2 \pi k_{s}} e^{-\lambda v \xi} K_{0}(\lambda v r)
$$

Onde $\mathrm{K}_{0}$ seria a função de Bessel de segundo tipo e ordem zero. 
Esta solução, porém, seria restrita a taxa de oxidação constante, e poderia ainda ser refinada por um q que variasse e função da espessura como apresentado a seguir:

$$
Q=Q_{0}\left(1-\frac{\alpha z^{\prime}}{g}\right)
$$

onde:

Qo é o calor por unidade de tempo e de comprimento,

g a espessura da chapa e

$\alpha$ o decréscimo da taxa de oxidação.

GRONG $^{[85]}$ em seu trabalho cita que uma solução analítica global para o modelamento com equações diferenciais para o estudo do fluxo de calor partiria do pressuposto que as propriedades térmicas do material fossem constantes e independentes da temperatura, o que não só para a maioria dos materiais e ligas é uma premissa falsa, como também o fluxo de calor de uma dada peça é afetado por alterações na sua composição química e pela história térmica da mesma.

Ainda conforme este autor, não levar estes fatos em consideração cria restrições ao uso de modelos obtidos, porém dentro de uma dada faixa de temperatura estudada, a solução de adotar de valores médios para fatores como condutividade e difusividade térmica, por exemplo, apresenta muito boa resposta quando se faz a verificação experimental correlacionando-se os resultados teóricos e experimentos práticos.

Levando este fato em consideração e com base nas equações 35 e 36, GRONG ${ }^{[85]}$ apresenta uma solução muito próxima da de ROSENTHAL ${ }^{[1]}$ que é apresentada na equação 37.

$$
\frac{T-T_{0}}{T_{c}-T_{0}}=\frac{Q}{2 \pi k d} e^{\left(-\frac{v x}{2 a}\right)} K_{0}\left(\frac{v r}{2 a}\right)
$$


Onde:

$\mathrm{T}$ = temperatura máxima atingida

$\mathrm{T}_{0}=$ temperatura inicial

$\mathrm{Tc}=$ Temperatura de referência (temperatura de corte)

$\mathrm{Q}=$ Potência $(\mathrm{q}$ chama $+\mathrm{q}$ oxidação do $\mathrm{Fe})$

$\mathrm{k}=$ condutividade térmica $\left(\mathrm{W} / \mathrm{mm}^{2}{ }^{\circ} \mathrm{C}\right)$

$\mathrm{d}=$ espessura do material

$\mathrm{v}=$ velocidade de deslocamento da fonte de calor sobre a peça

$\mathrm{x}=$ distância medida no eixo $\mathrm{x}$

$\mathrm{a}=$ difusividade térmica

$\mathrm{K}_{0}=$ função de Bessel de segundo tipo e ordem zero

$r=$ localização do ponto estudado: $\left(\varsigma^{2}+y^{2}\right)^{(1 / 2)}$

$\varsigma=(v x) /(2 a)$

$\mathrm{y}=$ distância medida no eixo y

Já no trabalho de GLIZMANENKO e YEVSEYEV ${ }^{[2]}$ é apresentada uma metodologia para o cálculo do balanço energético considerando como entradas de calor: o calor de chama, da combustão do Fe e das impurezas e como saídas: calor consumido na chama de pré-aquecimento, na combustão do Fe e impurezas, para a escória retida, para a escória expulsa e o calor perdido com radiação, aquecimento de gases da reação e com o $\mathrm{O}_{2}$ não utilizado. 


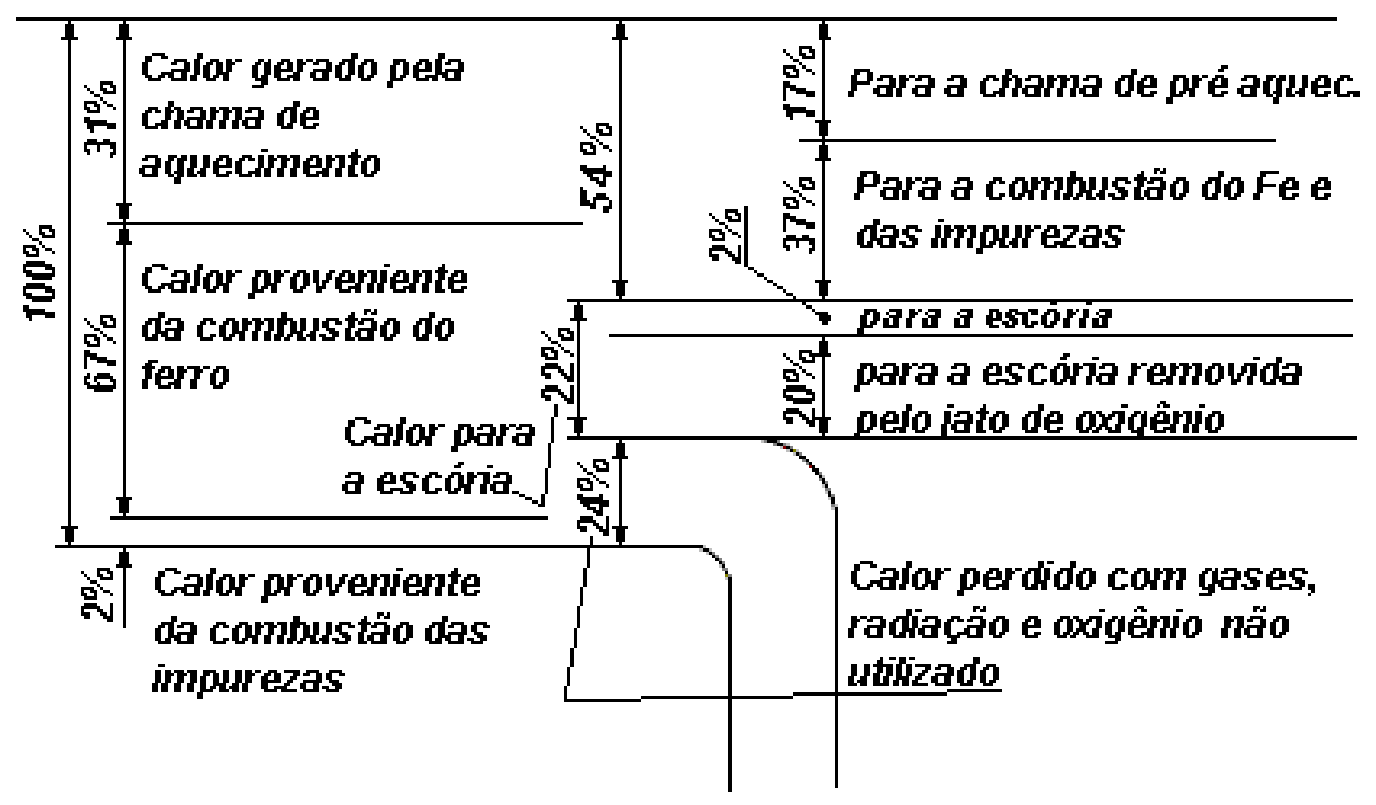

Figura 18 - Balanço térmico no oxicorte para chapa de $15 \mathrm{~mm}$. Adaptado de ${ }^{[2]}$

E a partir deste estudo pode ser calculado o calor da chama e da combustão separadamente, o que é apresentado variando em função da espessura para o processo.

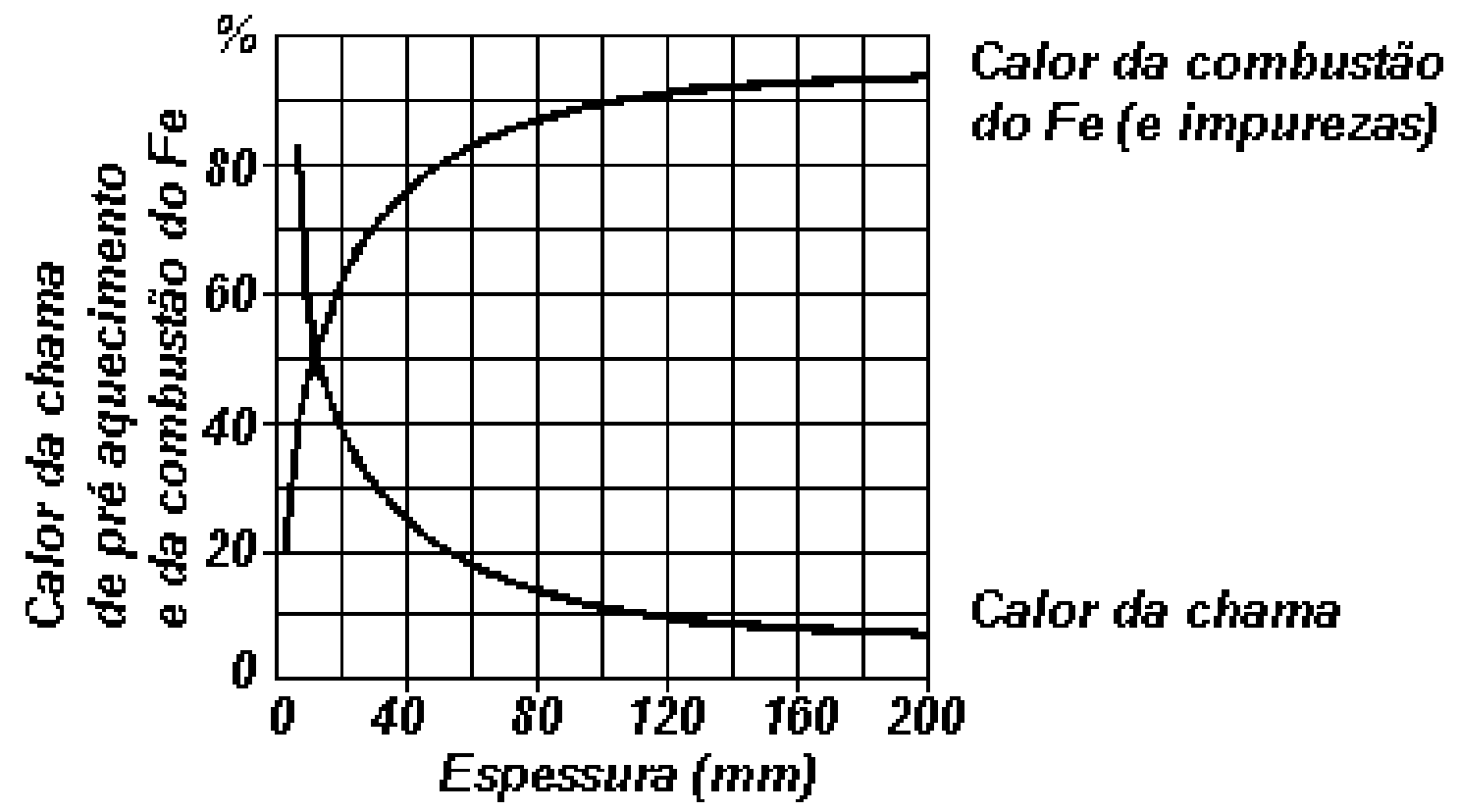

Figura 19 - Calor da chama x calor de combustão no oxicorte ${ }^{[2]}$ 


\subsubsection{TERMODINÂMICA APLICADA NO OXICORTE}

$\mathrm{O}$ processo oxicorte é um processo de oxidação do $\mathrm{Fe}$ contido no aço. O óxido formado é em seguida fundido e expulso pelo jato de $\mathrm{O}_{2}$. Operações como estas envolvem os principais aspectos estudados pela termodinâmica: estudo das variações de massa e de energia. Conforme definição de ADAMIAN ${ }^{[93]}$, a Termodinâmica estuda os fenômenos caloríficos e mecânicos simultâneos às transformações que estes ou causam ou são conseqüência.

O ferro, que em condições favoráveis é metaestável, fora destas condições é instável tendendo a retornar à forma de óxidos. No processo de corte esta reação é acelerada, havendo um considerável ganho exotérmico. As reações do ferro puro com o $\mathrm{O}_{2}$ e as energias envolvidas na formação destes óxidos são as apresentadas nas equações 5, 6 e 7 . Algumas outras características do ferro e dos óxidos de ferro são apresentadas na tabela 5 , onde são mostradas as faixas de valores encontrados nas diferentes fontes consultadas.

TABELA 5 - ALGUMAS PROPRIEDADES

DO FERRO E SEUS ÓXIDOS ${ }^{[93-100]}$

\begin{tabular}{|l|c|c|c|c|c|}
\hline Material & Nome & $\begin{array}{c}\text { Temp. } \\
\text { de fusão }\end{array}$ & $\begin{array}{c}\% \text { de } \mathrm{O}_{2} \\
\text { (peso) }\end{array}$ & $\begin{array}{c}\Delta \mathrm{H}_{\mathrm{f}} \\
(\mathrm{kJ} / \mathrm{mol} \text { de } \mathrm{Fe})\end{array}$ & $\begin{array}{c}\Delta \mathrm{S}^{0} \\
(\mathrm{~J} / \mathrm{Kmol} \text { de } \mathrm{Fe})\end{array}$ \\
\hline $\mathrm{Fe}$ & Ferro & $1534^{\circ} \mathrm{C}$ & 0 & 0 & 27,3 \\
\hline $\mathrm{FeO}$ & Wustita & $1370^{\circ} \mathrm{C}$ & $\begin{array}{c}23,1 \mathrm{a} \\
25,6(1)\end{array}$ & $-266,69 \mathrm{a}-272,00$ & 57,5 a 60,8 \\
\hline $\mathrm{Fe}_{2} \mathrm{O}_{3}$ & Hematita & $\begin{array}{c}\text { Decompõe } \\
\text { a } 1457^{\circ} \mathrm{C}\end{array}$ & 30 & $-822,70$ a $-824,20$ & 87,4 a 90,0 \\
\hline $\mathrm{Fe}_{3} \mathrm{O}_{4}$ & Magnetita & $1590^{\circ} \mathrm{C}$ & 27 & $-1117,87$ a $-1121,0$ & 146,0 a 146,4 \\
\hline
\end{tabular}

(1) - A variação dos teores de $\mathrm{O}_{2}$ na Wustita ocorre em função das variações da concentração do $\mathrm{O}_{2} \mathrm{e}$ da temperatura. Isto é possível devido às lacunas existentes na rede cristalina do $\mathrm{FeO}$.

Uma breve análise dos dados da tabela 5 mostra que, embora a temperatura de fusão da magnetita seja superior a do Fe puro $\left(1534^{\circ} \mathrm{C}\right)$, energeticamente a formação deste óxido é a reação mais favorável.

Há diversos estudos sobre a composição química da escória. Além dos óxidos citados, encontra-se na escória também Fe puro, tanto arrastado pela força do jato de $\mathrm{O}_{2}$, 
que $^{[23,101]}$ podem estar presentes numa faixa de 10 a $40 \%$, como também Fe resultante da decomposição da wustita conforme citado por diferentes autores ${ }^{[102-104]}$. A decomposição da wustita, durante o resfriamento, ocorre da seguinte forma:

$$
4 \mathrm{FeO} \Leftrightarrow \mathrm{Fe}_{3} \mathrm{O}_{4}+\mathrm{Fe}
$$

A literatura ${ }^{[23,101]}$ mostra que a exata composição da escória depende da espessura da chapa, velocidade de corte, pressão e concentração do $\mathrm{O}_{2}$, além da composição química do aço cortado. GLIZMANENKO e YEVSEYEV ${ }^{[2]}$ também sustentam este argumento, embora afirmando que a espessura da chapa tenha um peso maior nesta variação. Já na referência ${ }^{[48]}$ é apresentada a variação da composição química da escória apenas em função da variação da velocidade de corte.

Porém, é consenso entre todos estes autores que o conhecimento da composição química da escória é de fundamental importância para o estudo termoquímico do processo. Um estudo curioso, mas pouco prático, de GLIZMANENKO e YEVSEYEV ${ }^{[2]}$ apresenta as composições químicas das escórias analisadas no decorrer dos anos 1933 a 1959, com valores totais variando entre 60 a 95,8\%, muito provavelmente devido as limitações das condições de análise da época.

Estes mesmos autores propõem uma interessante solução para este problema onde, após diversas análises de escória adotaram os valores médios dos teores de óxidos encontrados como base da composição química para fazer o balanço de massa do oxicorte. Assumindo uma escória com 30\% (em peso) $\mathrm{FeO}, 50 \% \mathrm{Fe}_{3} \mathrm{O}_{4}$ e $20 \%$ Fe puro, obtiveram como resultado que 0,277 partes em peso de $\mathrm{O}_{2}$ com $100 \%$ de concentração seriam suficientes para oxidar uma parte em peso de Fe. No oxicorte este valor mostra-se falso, uma vez que boa parte do calor gerado pela reação exotérmica consome-se aquecendo a região adjacente ao corte, além do que considerável parte do $\mathrm{O}_{2}$ é consumido para a expulsão dos óxidos fundidos. 
A própria pesquisa sobre o calor consumido na reação ser gerado na chama ou na reação exotérmica, já foi objeto de estudo de alguns pesquisadores. É consenso que modifica-se com a variação da espessura, embora só este fator não explicaria toda a variação encontrada. Algumas referências consultadas envolvem o equacionamento de problemas semelhantes ${ }^{[106,108]}$, enfatizam a questão da concentração do $\mathrm{O}_{2}{ }^{[107,109,110]} \mathrm{e}$ apontam $^{[48,105]}$ para uma distribuição do calor conforme os valores apresentados na tabela 6 :

TABELA 6 - INFLUÊNCIA DA CHAMA DE
AQUECIMENTO NA COMBUSTÃO DO Fe ${ }^{[104,105]}$
\begin{tabular}{|cc|c|}
\hline \multicolumn{2}{|c|}{ Espessura } & Teor de calor consumido na reação \\
$(\mathrm{mm})$ & $(\mathrm{pol})$ & proveniente da chama $(\%)$ \\
\hline 10 & $(3 / 8 ”)$ & $30 \%$ \\
\hline 25 & $(1 ”)$ & $15 \%$ \\
\hline 225 & $(9 ")$ & $5 \%$ \\
\hline
\end{tabular}

É importante destacar que em relação aos elementos químicos anteriormente discutidos que podem estar presentes na composição química do aço, e também em relação a S, P e Si, enquanto estes teores estiverem com valores muito baixos (somatória menor que $3 \%$ ) a energia adicionada na reação devido a combustão destes elementos é desprezível.

\subsubsection{CONCENTRAÇÃO DO REAGENTE OXIGÊNIO}

Diversos tópicos têm direta ou indiretamente relação com a concentração do $\mathrm{O}_{2}$. O que aborda mais claramente é o tópico utilização de bicos com cortina externa protetora do jato central de $\mathrm{O}_{2}$, onde a função da cortina de $\mathrm{O}_{2}$ é exatamente evitar a contaminação do reagente para não diminuir sua concentração na reação. É importante observar que a maior velocidade de saída do $\mathrm{O}_{2}$ de corte propiciada por estes bicos, embora seja usualmente relacionada com a cortina, é na verdade devido as maiores pressões com que o bico trabalha. A maior pressão, na verdade, é uma necessidade para expulsar a maior quantidade de óxido formado devido a maior concentração com que o reagente chega a reação. 
A maior velocidade do $\mathrm{O}_{2}$ seria então necessária para expulsar os produtos e contaminantes formados na reação, possibilitando assim que o reagente atinja as camadas mais profundas na espessura do material.

A limitação de utilizar altíssimas velocidades no processo poderia ser solucionada com uma maior quantidade de calor liberada pela reação, pois a mesma, é extremamente exotérmica. Assim, havendo maior concentração do $\mathrm{O}_{2}$, haverá mais reação e conseqüentemente maior liberação de calor.

A concentração do reagente $\mathrm{O}_{2}$ é de fundamental importância para o funcionamento e a cinética do processo. LABOURIAU ${ }^{[110]}$ em seu trabalho mostra a impossibilidade de realização do corte utilizando $\mathrm{O}_{2}$ com concentração de apenas $90 \%$. Quando a concentração do $\mathrm{O}_{2}$ diminui, ocorre um retardamento na oxidação do metal e mais gases são consumidos por unidade de tempo para a mesma largura de sangria.

Dois estudos de diferentes autores ${ }^{[11,83]}$ e utilizando-se de diferentes espessuras, apresentam a mesma curva de decréscimo da velocidade (da reação química que pode, neste caso, ser entendida como velocidade de corte) em função do decréscimo da concentração do $\mathrm{O}_{2}$. $\mathrm{O}$ estudo feito pela ref. ${ }^{[83]}$ é apresentado na figura $20^{[83]}$, enquanto o estudo da referência ${ }^{[111]}$ é apresentado na figura 21.

Além da relação direta entre a concentração do $\mathrm{O}_{2}$ e a velocidade de corte RAMALHO e BRANDI mostram em 2 trabalhos que a concentração também afeta diretamente a composição química dos óxidos produzidos ${ }^{[112]}$ e a largura da sangria ${ }^{[113]}$. 


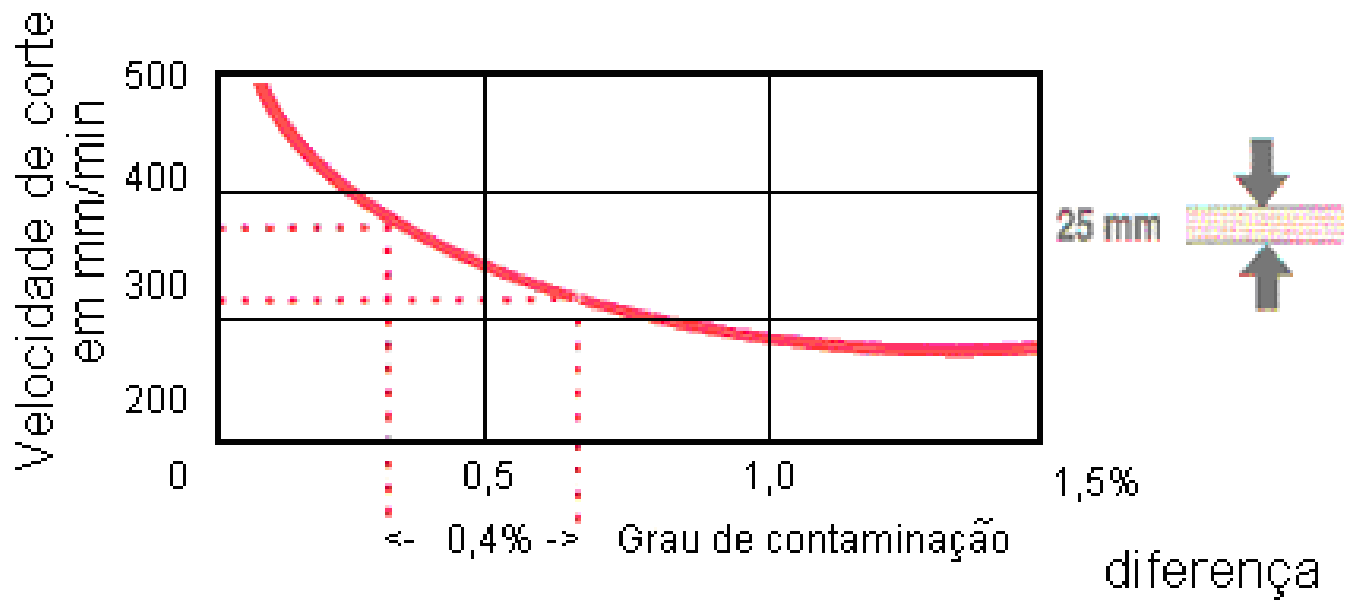

Concentraçao do $\mathrm{O}_{2}$ de corte $99,7 \% \quad 99,3 \% \quad 0,4 \%$ Velocidade de corte $\mathrm{mm} / \mathrm{min} \quad 395 \quad 335 \quad 15,0 \%$

Figura 20 - Relação entre concentração do $\mathrm{O}_{2}$ e velocidade de corte (chapa $\left.25 \mathrm{~mm}\right)^{[83]}$

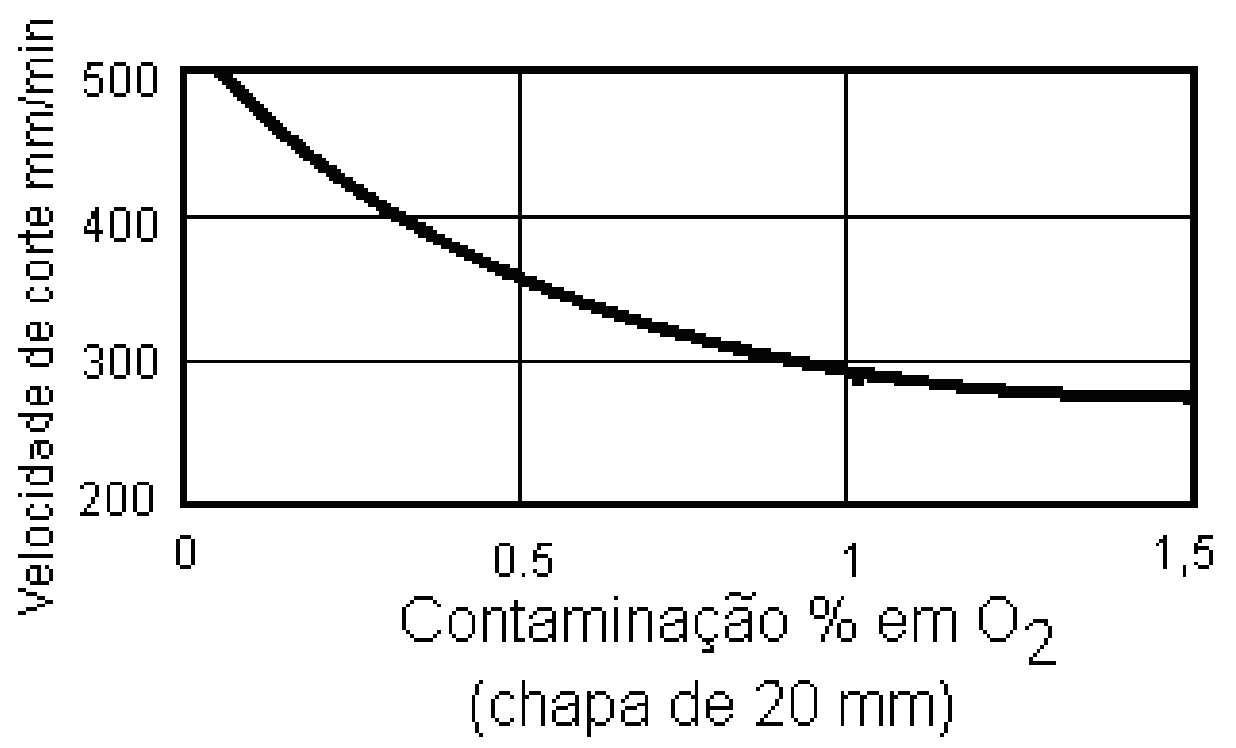

Figura 21 - Relação entre concentração do $\mathrm{O}_{2}$ e velocidade de corte $(\mathrm{e}=20 \mathrm{~mm})^{[111]}$ 


\section{OBJETIVOS}

Os objetivos deste trabalho são:

a) Quantificar a composição química da escória obtida no processo oxicorte em função dos tratamentos de processo empregados (espessura da chapa, temperatura inicial da chapa e concentração de oxigênio de corte);

b) Calcular o valor da quantidade de calor gerada por oxidação no processo de corte em função das variáveis estudadas;

c) Avaliar qual o mecanismo principal de fornecimento de calor durante o corte em função dos parâmetros estudados.

d) Montar redes neurais artificiais para previsão de resultados que são necessários para realizar a avaliação térmica do processo de oxicorte e que não estão disponíveis na literatura. 


\section{MATERIAIS E MÉTODOS}

Foram cortadas chapas de aço carbono ASTM A 36 de diferentes espessuras (12,7 $25,4,38,1$ e $50,8 \mathrm{~mm}$ ) com o processo oxicorte mecanizado utilizando-se acetileno como gás combustível. As superfícies de corte foram caracterizadas no seu formato (rugosidade e fusão de extremidades) e dimensões (ângulo de corte). Foi também determinada a composição química dos materiais utilizados e dos óxidos produzidos

Em seguida os dados obtidos foram tratados matematicamente e com técnicas de inteligência artificial, nomeadamente redes neurais artificiais.

\subsection{CHAPAS DE AÇO CARBONO}

O material das chapas utilizadas foi aço ao carbono ASTM A36. A composição química das chapas é a apresentada na tabela a seguir. Os valores apresentados são a média de 3 análises feitas em cada chapa de onde foram retirados os corpos de prova.

TABELA 7 - COMPOSIÇÃO QUÍMICA DAS CHAPAS

\begin{tabular}{|c|c|c|c|c|c|c|}
\hline Chapas & C & Si & Mn & P & S & Fe \\
\hline $12,7 \mathrm{~mm}$ & 0,14 & 0,16 & 0,85 & 0,01 & 0,02 & 98,82 \\
\hline $25,4 \mathrm{~mm}$ & 0,16 & 0,22 & 1,08 & 0,01 & 0,03 & 98,52 \\
\hline $38,1 \mathrm{~mm}$ & 0,15 & 0,18 & 0,98 & 0,01 & 0,015 & 98,65 \\
\hline $50,8 \mathrm{~mm}$ & 0,16 & 0,21 & 1,23 & 0,01 & 0,02 & 98,37 \\
\hline
\end{tabular}

Os corpos de prova foram cortados inicialmente no oxicorte, etapa esta que já serviu para determinação dos parâmetros iniciais de trabalho, seguido de usinagem apenas para acerto das faces cortadas em uma frezadora convencional e por fim foram feitos os furos e a usinagem final de calibração em um equipamento com comando numérico computadorizado, onde foram colocados juntos os lotes de chapas de mesma espessura para assegurar que todas ficassem com exatamente a mesma dimensão final, pois um dos itens controlados foi o peso das peças antes e após o corte para a determinação do peso do material removido na sangria por oxidação. 
Além desta razão, a furação num equipamento CNC teve por objetivo fazer os furos nos locais onde foram colocados os termopares para a aquisição dos dados do ciclo térmico do processo. É de fundamental importância que estes furos tivessem sua profundidade conhecida e idêntica para todas as peças, uma vez que uma pequena distância em relação à fonte de calor pode causar grandes diferenças na aquisição do valor da temperatura.

O desenho das peças com as dimensões e detalhes da furação é apresentado na figura 22.

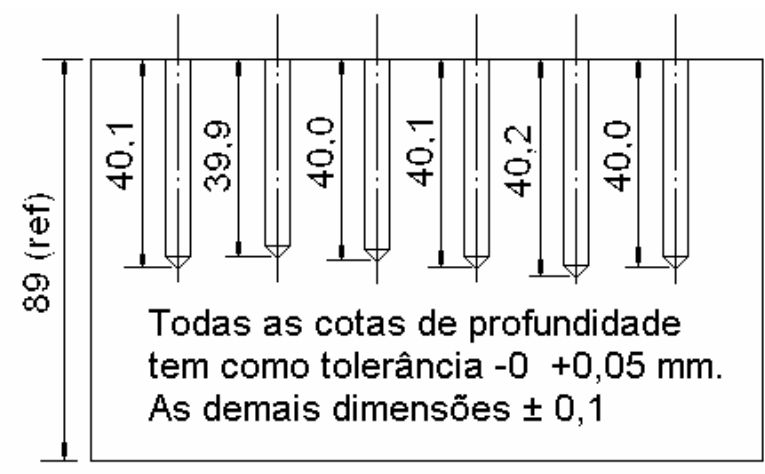

Diâmetro dos 6 furos $=5,6 \mathrm{~mm}$.

\section{Profundidade} medida no fim do furo feito com o ângulo normal da afiação da broca.

as furações foram feitas exatamente

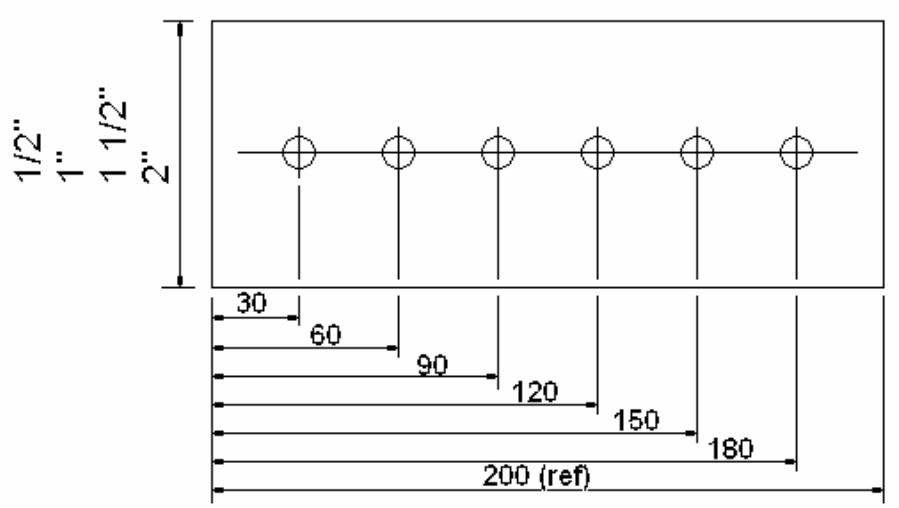
iguais em todas as peças, sempre na linha de centro das chapas, para as 4 diferentes espessuras

Figura 22 - Desenho da preparação das peças

As distâncias dos primeiros furos a lateral da peça foram propositadamente deixadas em dimensões diferentes, $30 \mathrm{~mm}$ de um lado e $20 \mathrm{~mm}$ de outro, para que durante o processamento a posição das peças não fosse invertida, uma vez que as profundidades dos furos são diferentes. Além disto, a cota mínima de $20 \mathrm{~mm}$ está acima do valor para atingir o regime semi-estacionário. Este foi determinado conforme a metodologia apresentada por BRANDI $^{[114]}$ que indicou que o valor para atingi-lo seria $13 \mathrm{~mm}$. 
As peças foram pesadas em uma balança marca Marte modelo A4/40 com precisão de 3 casas decimais. A metodologia adotada foi repetir cada pesagem 3 vezes e adotar o valor médio. Dada uma pequena variação no comprimento das peças, houve variação no peso das mesmas.

\subsection{GASES UTILIZADOS}

Foi utilizado $\mathrm{O}_{2}$ industrial (concentração mínima 99,5\%) e laboratorial (concentração mínima 99,95\%). O acetileno, que tem menor influência no processo, foi utilizado apenas na denominação industrial (concentração mínima 99,5\%).

No oxicorte são necessários 2 suprimentos de $\mathrm{O}_{2}$ : um para o jato de corte e um para a chama. Em pequenas operações manuais estas podem interligar-se no mesmo cilindro, mas em maçaricos para aplicações automatizadas estas devem ser separadas. Isto possibilita que os cortes possam ser feitos com gases supridos a partir de cilindros com diferentes concentrações de $\mathrm{O}_{2}$, uma vez que o $\mathrm{O}_{2}$ da chama pouco interfere na oxidação do material. Assim este trabalho contemplou a utilização do produto ultrapuro apenas para o gás de corte.

Com o objetivo de não haver trocas de cilindros durante toda a execução da tese, foram construídas 3 centrais de cilindros: $1+1$ para acetileno, $1+1$ para $\mathrm{O}_{2}$ de chama e $3+3$ para $\mathrm{O}_{2}$ de corte. Isto garantiu não haver troca do $\mathrm{O}_{2}$ durante toda a realização dos experimentos.

$\mathrm{O}_{2}$ ultrapuro foi suprido diretamente por um cilindro. Visando que a troca dos gases não causasse alteração no processo nos aspectos de regulagem da pressão ou vazão, foi utilizado um dispositivo tipo " $\mathrm{Y}$ " onde o $\mathrm{O}_{2}$ industrial e o ultrapuro foram conectados e regulados de maneira idêntica antes da execução dos cortes. Assim na substituição não foi causada nenhuma alteração além da troca do produto em si. Para a medição das vazões e pressões com precisão, foi especialmente desenvolvido um painel de medições. 


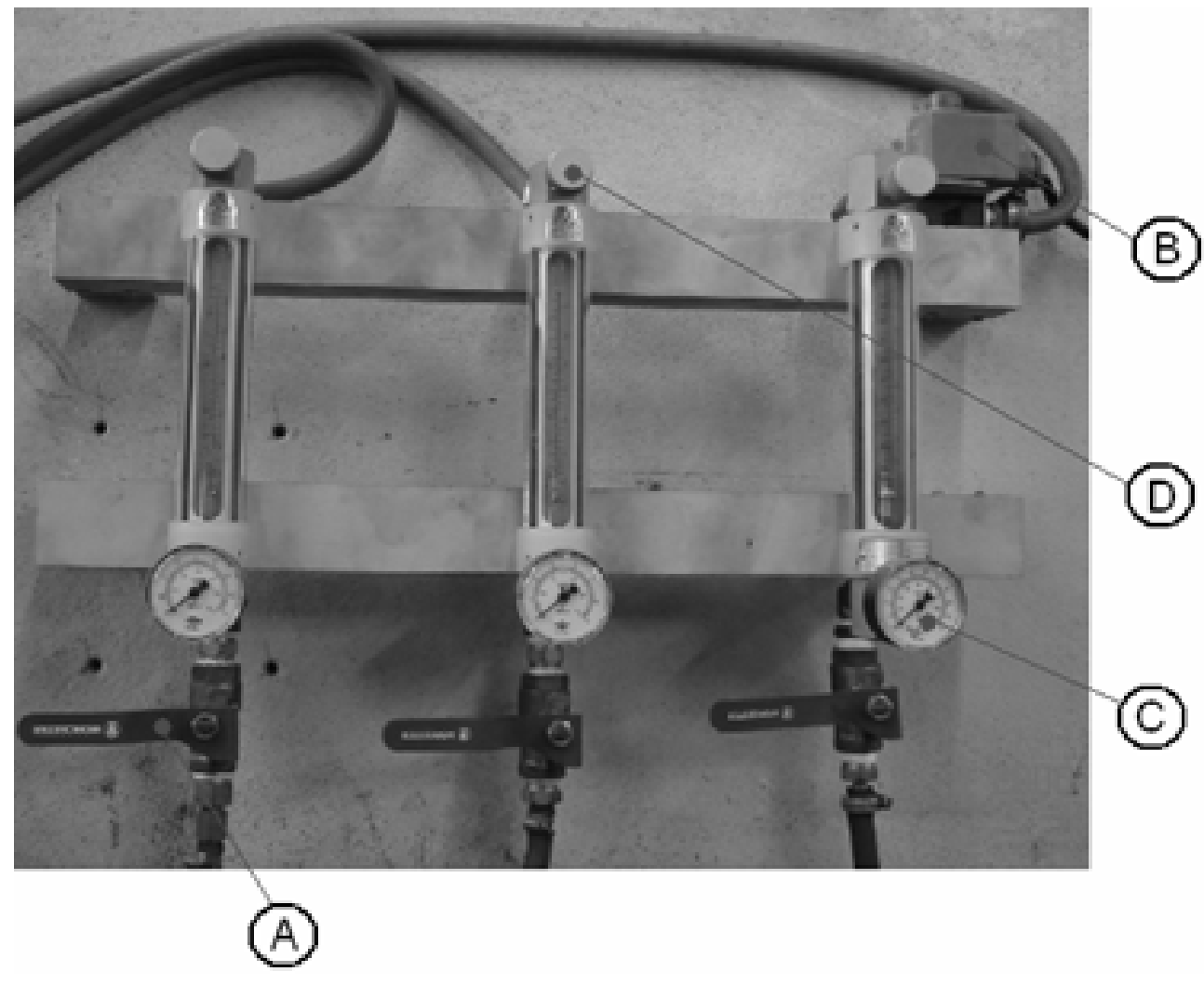

Figura 23 - Painel montado para a medição e suprimento de diferentes gases

Este painel foi desenvolvido com válvulas de esfera para fechamento rápido e interrupção do processo (A), solenóide para liga/desliga do $\mathrm{O}_{2}$ de corte (B), manômetros para medida da pressão (C) colocados antes do ajuste da vazão (D).

\subsection{BANCADA DE EXPERIMENTOS}

A bancada de experimentos foi construída tendo por base uma caixa metálica onde seriam colocados os recipientes de alumínio para a captação dos óxidos durante o corte. A escolha da utilização de alumínio para as caixas interiores foi para evitar contaminações dos óxidos com o material que os capturassem, caso as mesmas fossem construídas de aço. Assim qualquer ocorrência de grandes concentrações de Al nos óxidos seria atribuída ao processamento e não a operação. A bancada utilizada é apresentada na figura 24. 


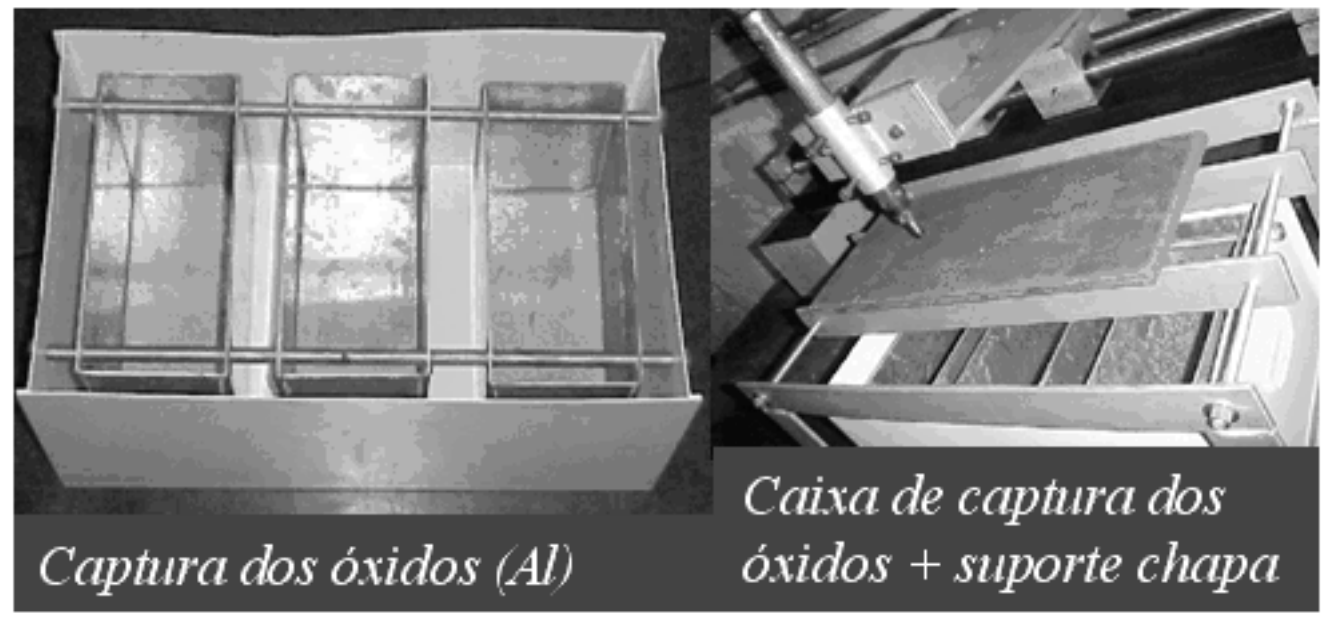

Figura 24 - Caixa de captura dos óxidos e bancada

Os cortes foram realizados com a chapa apoiada sobre uma chapa de 2" de espessura com um furo retangular central por onde os óxidos escoavam. Esta chapa de grande dimensão teve por finalidade impedir, com seu peso, qualquer movimentação do sistema durante a operação.

\subsection{PLANEJAMENTO DO EXPERIMENTO}

O experimento seguiu um planejamento $2^{2}$ com as seguintes variáveis: concentração do $\mathrm{O}_{2}$ e temperatura de pré-aquecimento, uma repetição e 4 espessuras diferentes perfazendo um total de 32 corpos de prova. Toda a seqüência de execução dos testes foi escolhida aleatoriamente com a função ALEATÓRIO do software Excel. O planejamento do experimento é apresentado nas tabelas a seguir. Os números maiores que 8 na ordem de execução são relativos a experimentos que substituem os de numeração menor por estes terem apresentado 2 diferentes problemas durante a execução: escape de termopar ou falha na aquisição de dados.

TABELA 8 - PLANEJAMENTO DO EXPERIMENTO CHAPAS DE 12,7 mm

\begin{tabular}{|c|c|c|c|}
\hline Ordem de execução & Identificação & Temperatura & Concentração $\mathrm{O}_{2}$ \\
\hline $\mathbf{7}$ & 11 & $30^{\circ} \mathrm{C}$ & UP \\
\hline $\mathbf{1}$ & 2 & $30^{\circ} \mathrm{C}$ & Industrial \\
\hline $\mathbf{6}$ & 10 & $230^{\circ} \mathrm{C}$ & UP \\
\hline $\mathbf{8}$ & 12 & $230^{\circ} \mathrm{C}$ & UP \\
\hline $\mathbf{5}$ & 8 & $30^{\circ} \mathrm{C}$ & UP \\
\hline $\mathbf{3}$ & 5 & $30^{\circ} \mathrm{C}$ & Industrial \\
\hline $\mathbf{2}$ & 9 & $230^{\circ} \mathrm{C}$ & Industrial \\
\hline & 1 & $230^{\circ} \mathrm{C}$ & Industrial \\
\hline
\end{tabular}


TABELA 9 - PLANEJAMENTO DO EXPERIMENTO CHAPAS DE 25,4 mm

\begin{tabular}{|c|c|c|c|}
\hline Ordem de execução & Identificação & Temperatura & Concentração $\mathrm{O}_{2}$ \\
\hline $\mathbf{5}$ & $4 \mathrm{P}$ & $30^{\circ} \mathrm{C}$ & UP \\
\hline $\mathbf{6}$ & $9 \mathrm{P}$ & $30^{\circ} \mathrm{C}$ & UP \\
\hline $\mathbf{2}$ & $6 \mathrm{P}$ & $30^{\circ} \mathrm{C}$ & Industrial \\
\hline $\mathbf{1}$ & $11 \mathrm{P}$ & $30^{\circ} \mathrm{C}$ & Industrial \\
\hline $\mathbf{4}$ & $5 \mathrm{P}$ & $230^{\circ} \mathrm{C}$ & Industrial \\
\hline $\mathbf{7}$ & $2 \mathrm{P}$ & $230^{\circ} \mathrm{C}$ & UP \\
\hline $\mathbf{8}$ & $7 \mathrm{P}$ & $230^{\circ} \mathrm{C}$ & UP \\
\hline $\mathbf{3}$ & $1 \mathrm{P}$ & $230^{\circ} \mathrm{C}$ & Industrial \\
\hline
\end{tabular}

TABELA 10 - PLANEJAMENTO DO EXPERIMENTO CHAPAS DE 38,1 mm

\begin{tabular}{|c|c|c|c|}
\hline Ordem de execução & Identificação & Temperatura & Concentração $\mathrm{O}_{2}$ \\
\hline $\mathbf{1}$ & $12 \mathrm{M}$ & $30^{\circ} \mathrm{C}$ & Industrial \\
\hline $\mathbf{3}$ & $4 \mathrm{M}$ & $30^{\circ} \mathrm{C}$ & UP \\
\hline $\mathbf{2}$ & $6 \mathrm{M}$ & $30^{\circ} \mathrm{C}$ & Industrial \\
\hline $\mathbf{4}$ & $8 \mathrm{M}$ & $30^{\circ} \mathrm{C}$ & UP \\
\hline $\mathbf{7}$ & $3 \mathrm{M}$ & $230^{\circ} \mathrm{C}$ & UP \\
\hline $\mathbf{6}$ & $5 \mathrm{M}$ & $230^{\circ} \mathrm{C}$ & Industrial \\
\hline $\mathbf{8}$ & $7 \mathrm{M}$ & $230^{\circ} \mathrm{C}$ & UP \\
\hline $\mathbf{5}$ & $1 \mathrm{M}$ & $230^{\circ} \mathrm{C}$ & Industrial \\
\hline
\end{tabular}

TABELA 11 - PLANEJAMENTO DO EXPERIMENTO CHAPAS DE 50,8 mm

\begin{tabular}{|c|c|c|c|}
\hline Ordem de execução & Identificação & Temperatura & Concentração $\mathrm{O}_{2}$ \\
\hline $\mathbf{7}$ & $4 \mathrm{G}$ & $30^{\circ} \mathrm{C}$ & UP \\
\hline $\mathbf{1}$ & $14 \mathrm{G}$ & $30^{\circ} \mathrm{C}$ & Industrial \\
\hline 4 & $5 \mathrm{G}$ & $230^{\circ} \mathrm{C}$ & Industrial \\
\hline $\mathbf{8}$ & $8 \mathrm{G}$ & $30^{\circ} \mathrm{C}$ & UP \\
\hline $\mathbf{2}$ & $6 \mathrm{G}$ & $30^{\circ} \mathrm{C}$ & Industrial \\
\hline 3 & $1 \mathrm{G}$ & $230^{\circ} \mathrm{C}$ & Industrial \\
\hline 5 & $3 \mathrm{G}$ & $230^{\circ} \mathrm{C}$ & UP \\
\hline 6 & $7 \mathrm{G}$ & $230^{\circ} \mathrm{C}$ & UP \\
\hline
\end{tabular}

Como este trabalho visa comparar o comportamento do corte em diferentes espessuras, os seguintes parâmetros de trabalho foram mantidos constantes para todas as chapas nas diferentes espessuras cortadas:

- acetileno: vazão de 410 1/h e pressão de 0,5 bar

- $\mathrm{O}_{2}$ de chama: vazão de 476 1/h e pressão de 1,8 bar

- $\mathrm{O}_{2}$ de corte: vazão de 6675 1/h e pressão de 6 bar

- distancia bico-peça: 18,5 mm 
- velocidade de corte: $0,437 \mathrm{~m} / \mathrm{min}$

- bico de corte: número 3 da empresa AGA

Enquanto as variações realizadas nos experimentos foram os seguintes:

- espessuras: 12,$7 ; 25,4 ; 38,1$ e $50,8 \mathrm{~mm}$

- temperaturas de pré-aquecimento: 30 e $230^{\circ} \mathrm{C}$

- concentração do $\mathrm{O}_{2}$ 99,5 (industrial) e 99,95\% (ultra-puro)

\subsection{MEDIDA DA VELOCIDADE DE CORTE}

Para a medida da velocidade de corte com precisão foram soldados 2 cabos dentro da caixa de controle do dispositivo de movimentação do maçarico. Estes cabos obtiveram o sinal elétrico da tensão de armadura do potenciômetro do controle da velocidade do equipamento. De posse deste sinal foi feita uma leitura simples com um multímetro convencional e feitos alguns testes com um cronômetro para validação. A montagem deste artifício de leitura indireta, que possibilita a leitura da velocidade de avanço com a precisão de 2 casas decimais, é apresentada na figura 25.

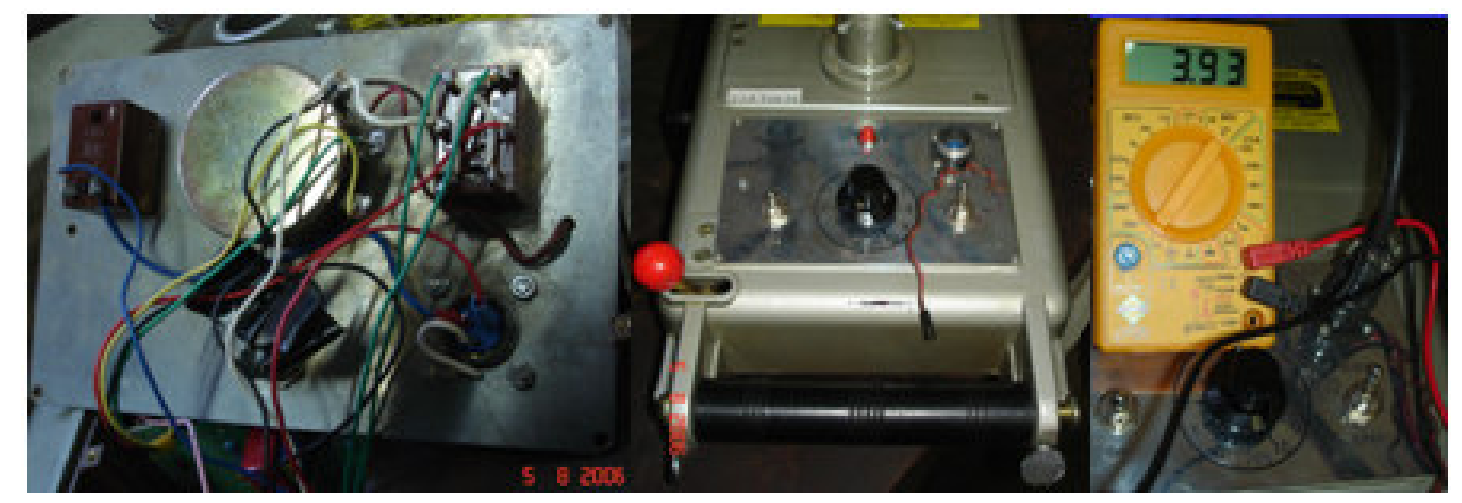

Figura 25 - Sistema montado para a leitura da velocidade de avanço do maçarico 


\subsection{MEDIÇÕES NAS SUPERFÍCIES CORTADAS}

Foram também medidos os seguintes tópicos: os ângulos do corte em relação a face da peça (eixo X), ângulo de corte em relação ao eixo da espessura da peça (eixo $Z$ ), comprimento real do corte. Estas medições foram realizadas com dispositivos normais de medição existentes no laboratório como paquímetros e micrometros e foram utilizadas na determinação das dimensões reais de corte, que são a base do cálculo da taxa de remoção de material

\subsection{MEDIÇÃO DA ESPESSURA DA ZONA FUNDIDA E DA ZONA AFETADA PELO CALOR (ZAC)}

A espessura da zona fundida indica se a distância bico peça era adequada e se a potência da chama era apropriada para a velocidade de avanço utilizada. A ZAC é a região intermediária entre zona fundida e o metal de base que não sofreu alterações em suas propriedades. A linha externa em direção da ZAC indica a temperatura de $723^{\circ} \mathrm{C}$, sendo por isso uma dimensão com posição e temperatura conhecidos que pode ser utilizada no cálculo do ciclo térmico. Estes valores foram medidos num estereoscópio marca Zeiss com ampliação de 5 X. Este equipamento conta com um sistema de aquisição de imagem Pixel link e software de tratamento de imagens Axionvision. O software Axionvision conta com ferramentas que possibilitam medições nas imagens, com as quais as medidas foram feitas e posteriormente documentadas. As figuras 26 e 27 apresentam exemplos destas medições. Com este equipamento é também possível classificar a qualidade da superfície de corte obtida julgando-a conforme a norma ISO $9013^{[115,116]}$. 


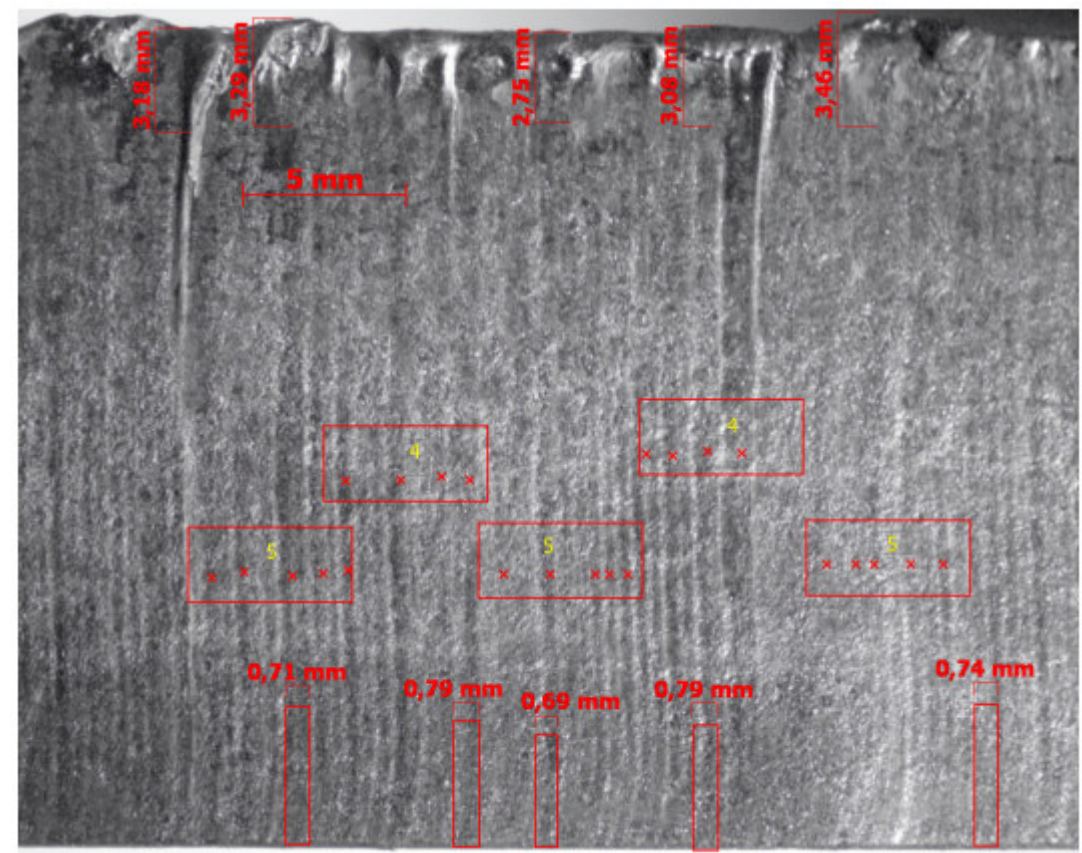

Figura 26 - Medições de defasagem do corte e espessura da zona fundida realizadas com o estereoscópio

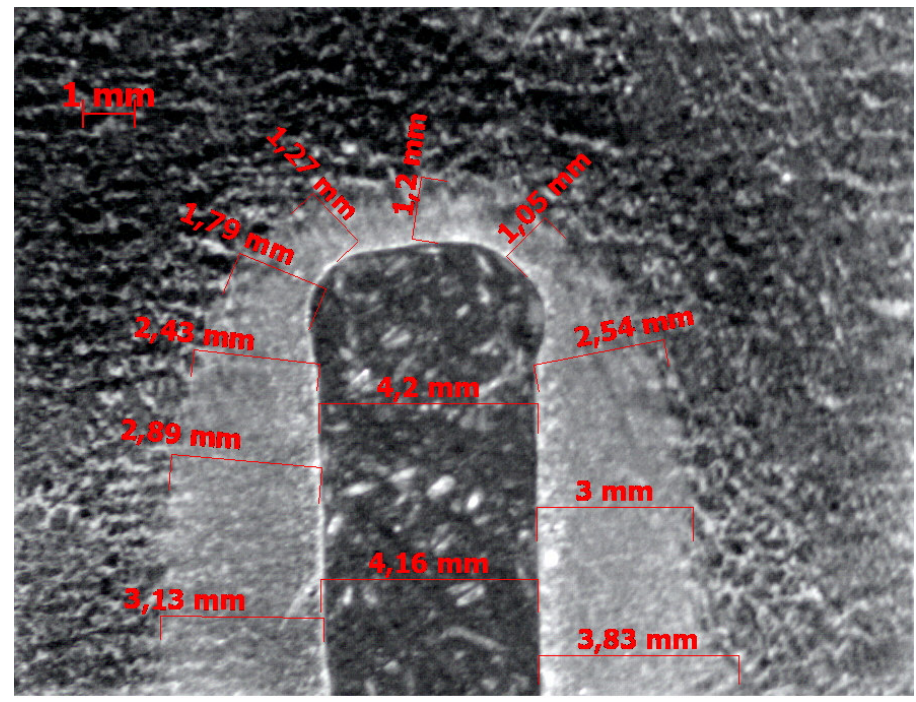

Figura 27 - Medição da dimensão da ZAC do oxicorte

\subsection{ANÁLISE QUÍMICA DOS ÓXIDOS}

A difração de raios $\mathrm{X}$ é uma técnica que permite identificar fases ou espécies minerais pelo espectro gerado a partir de uma estrutura cristalina submetida à incidência de um feixe de raios $\mathrm{X}$, sendo portanto uma técnica indicada para a análise de óxidos. 
De acordo com ANTONIASSI ${ }^{[117]}$, o princípio do processo consiste em submeter amostras a radiação $X$ de comprimento de onda $(\lambda)$ conhecido e verificar a disposição e intensidade dos planos paralelos na reflexão desta radiação. Os planos refletidos estão relacionados com as dimensões das células unitárias e as orientações dos planos interatômicos hkl específicos de cada material.

A intensidade difratada é dependente, entre outros fatores, do número de elétrons do átomo. Como os átomos são distribuídos no espaço de acordo com os vários planos atômicos, os diferentes planos de uma estrutura cristalina possuem diferentes densidades de átomos ou elétrons, o que faz com que as intensidades difratadas sejam conseqüentemente distintas para diferentes planos cristalinos.

A equação de Bragg que se refere a esse principio é:

$$
n \lambda=2 d \operatorname{sen} \theta
$$

onde:

$\lambda=$ corresponde ao comprimento de onda da radiação incidente

$\mathrm{n}=$ um número inteiro,

$\mathrm{d}=\mathrm{a}$ distância interplanar para o conjunto de planos hkl

$\theta=o$ ângulo de incidência e reflexão do feixe de raios $X$

A técnica de difração por raios $\mathrm{X}$ é uma técnica eminentemente qualitativa, muito utilizada para identificar materiais e fases ou ainda para indicar, nos casos de contaminação, a existência de outras formas cristalinas. Não é uma técnica quantitativa. Para a quantificação dos materiais e fases presentes em uma amostra com esta técnica é necessário utilizar o método de Rietveld.

O ensaio de difração por raios $\mathrm{X}$ foi feito em um equipamento PANalytical, modelo PW 1800 com configuração de tubo de $\mathrm{Cu}, 40 \mathrm{kV}$ e $40 \mathrm{~mA}$, fenda incidente fixa de 0,2 $\mathrm{mm}$, monocromador. 


\subsubsection{PREPARAÇÃO DAS AMOSTRAS PARA DRX}

Após a captação e retirada dos óxidos das caixas de Al estas foram pulverizadas em moinho planetário nas seguintes etapas: mistura com etanol na proporção 1:1, moagem em panela de ferro com volume de $300 \mathrm{ml}$ tendo como meio moedor esferas de ferro de 2 e 3 mm de diâmetro. Em seguida foram secas ao ar e separados em peneiramento nas frações maiores e menores que $0,074 \mathrm{~mm}$. Para o material retido nesta separação o procedimento foi repetido. A montagem da fração menor que $0,074 \mathrm{~mm}$ para análise é apresentada na figura 28.

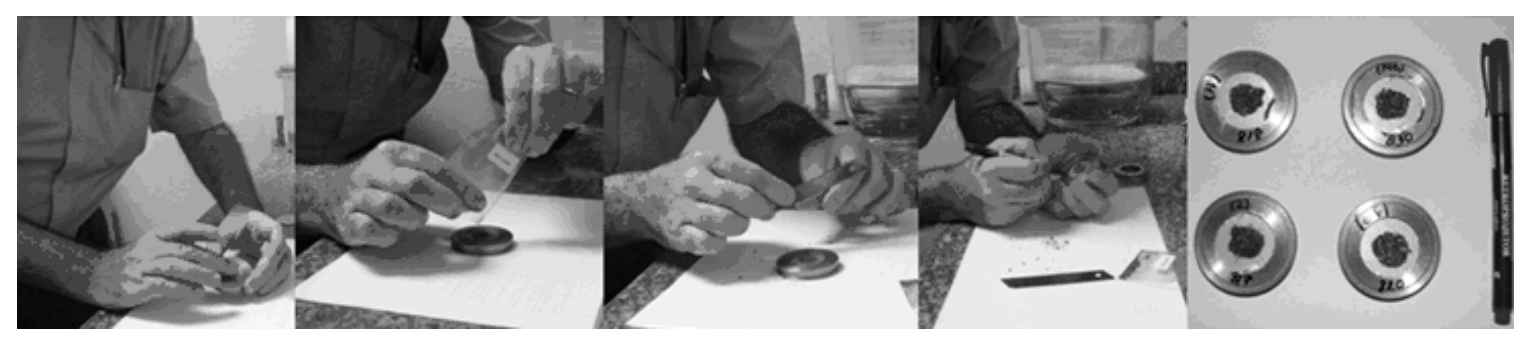

Figura 28 - Montagem da fração menor que 0,074 $\mathrm{mm}$ para difração

\subsubsection{O MÉTODO DE RIETVELD}

O método de Rietveld baseia-se na construção de um perfil difratométrico simulado baseado nos parâmetros estruturais das fases constituintes da amostra. Este perfil é sucessivamente ajustado de acordo com os parâmetros instrumentais do processo e as características da amostra. O objetivo do método é construir um padrão de difração que seja o mais próximo possível ao padrão da amostra observada.

O refinamento consiste em minimizar sucessivamente a soma das diferenças dos erros das intensidades observadas no padrão proposto e no observado. O método utilizado para a minimização das diferenças é o método dos mínimos quadrados, enquanto que os parâmetros ajustados (refinados) conforme ANTONIASSI ${ }^{[117]}$ e REYNOLDS ${ }^{[118]}$ são: fator de escala, linha de base ou background, perfil do pico, parâmetro de rede, fator de estrutura, deslocamentos e orientação preferencial. 
O trabalho de RAMALHO, ANTONIASSI et all ${ }^{[119]}$ apresenta uma metodologia especificamente desenvolvida para a quantificação de óxidos de ferro.

Para a caracterização dos óxidos foi realizada a difração nas duas frações granulométricas geradas na preparação, o que possibilitou em separado a quantificação da fração mais fina e a qualificação da fase grossa.

Para a quantificação foi utilizado o método de Rietveld, através do software HighScore Plus v.2.2 da empresa PANalytical, utilizando estruturas cristalinas do banco de dados da Inorganic Crystal Structures Database (National Institute of Standarts and Technology - NIST and Fachinformationszentrum Karlsruhe - FIZ) de 2004.

A fração retida em 0,074 mm, obtida após duas etapas de moagem ficou composta por essencialmente Fe metálico que é dúctil e na cominuição teve importante parcela que permaneceu mais grossa que as demais fases. Foi feito em seguida a difração qualitativa nesta fase retida com o objetivo de comprovar este fato.

A proporção das fases da amostra total foi obtida com o cálculo ponderado com as respectivas massas das duas frações.

\subsection{REGRESSÃO LINEAR MÚLTIPLA}

Um modelamento matemático tradicional com regressão linear é sempre uma alternativa para compreensão e entendimento de um processo. Ele visa correlacionar as variáveis para formular uma hipótese que é apresentada na forma de uma equação.

Esta pode ser verificada se está bem ajustada ao fenômeno através do cálculo do coeficiente de correlação, se as amostras representam adequadamente o fenômeno pode-se verificar com o teste de hipóteses e a influência de cada variável pode ser mensurada com a análise de variância. A utilização destes procedimentos torna o uso desta técnica bastante segura e confiável. BRANCO et al. ${ }^{[120]}$ mostram em seu trabalho a aplicação da análise da variância na regressão linear visando mensurar a parte explicável e a parte não explicável na em sua variação. 


\subsection{REDES NEURAIS ARTIFICIAIS (RNA)}

Redes Neurais Artificiais estão inseridas num contexto maior denominado Inteligência Computacional. Conforme CARVALHO ${ }^{[121]}$, a Inteligência Computacional é um ramo das Ciências da Computação que estuda máquinas (hardware) e sistemas computacionais (softwares) que tenham ou desenvolvam, a capacidade de realizar tarefas normalmente associadas à inteligência humana. Entre estas tarefas, podemos citar a percepção, o aprendizado, o reconhecimento, a evolução e a adaptação ${ }^{[122-124]}$.

Definição semelhante apresenta HAYKIN ${ }^{[125]}$ que define este conjunto de técnicas como Inteligência Artificial. Segundo este autor, um sistema de Inteligência Artificial deve ter a capacidade de: armazenar conhecimento, aplicar o conhecimento e gerar novo conhecimento. Por padronização, será adotado aqui o termo Inteligência Computacional.

Entre outros autores, THOMÉ e OLIVEIRA ${ }^{[126]}$ também citam como sendo pertencentes a Inteligência Computacional as técnicas: Lógica Fuzzy, que manipula informações imprecisas como as do processamento lingüístico, os algoritmos genéticos, onde o processamento de informações baseia-se em algoritmos que competem entre si, e os sistemas híbridos, que vem a ser união destas técnicas, como por exemplo: neuro-fuzzy, fuzzy-genéticos ou neuro-genéticos.

Nos dias atuais, graças a grande disponibilidade de capacidade de processamento de dados existente, a utilização de Redes Neurais Artificiais é uma tarefa que, se mantém sua complexidade na implementação correta dos parâmetros, tem toda a parte de cálculo mais trabalhoso executada por programas de computadores. Estes podem ser desenvolvidos para este fim utilizando ferramentas como as linguagens $\mathrm{C}, \mathrm{C}^{++}$ou Visual Basic, podem ser programas mais genéricos ${ }^{[127]}$ que apresentam bibliotecas pré programadas para a utilização de Redes Neurais como por exemplo o MATLAB, ou podem ser softwares específicos para a utilização de Redes Neurais como por ex: SNNS, Qwiknet, Easynn ou Tlearn. 


\subsubsection{ASPECTOS GERAIS DAS RNAS}

Conforme DINIZ ${ }^{[128]}$ as RNA foram desenvolvidas visando copiar o modo de operação do cérebro. Isto requereu o desenvolvimento de algoritmos que imitassem o neurônio biológico em seu modo de operação, o que engloba: recepção da informação, conexão, processamento, interatividade com os demais neurônios e geração de uma resposta interpretável.

Na definição de ANDRADE e CARVALHO ${ }^{[129]}$, o objetivo de uma RNA seria "obter performance semelhante a dos humanos na resolução de problemas para os quais, métodos tradicionais de computação mostram-se inadequados", enquanto CASTELHANO et $\mathrm{al}^{[130]}$, afirmam que as RNA apresentam excelentes resultados em capturar as informações gerais de um sistema que não tenha a relação analítica tão explicita entre as suas variáveis sendo ideais para ser aplicadas em sistemas com grande volume de dados e sem boa informação sobre a estrutura destes.

Pode-se também assumir que a RNA seja um aglomerado de elementos processadores elementares, os neurônios, que ao acumularem as pequenas partes do conjunto da informação e os pesos relativos à significância desta parte, estariam acumulando juntos o "conhecimento" da rede como um todo.

Ainda conforme DINIZ ${ }^{[128]}$, para "imitar" numericamente o cérebro, a RNA precisa de arquiteturas paralelas, de algoritmos adequados na fase de "aprendizado" e alta capacidade de processamento. Não é necessário, porém, que os modelos sejam perfeitos em relação à realidade física do problema, e isto é uma das grandes vantagens das RNA, pois qualquer quantidade de dados a respeito de um problema, quando é suficientemente "real", apresenta os desvios normais relativos ao controle de qualquer processo.

Uma RNA, devido a sua boa capacidade de adaptação, pode ser treinada mesmo com dados que contenham estes desvios normais. Dentre suas principais vantagens pode-se destacar: a tolerância a falhas, a resposta em tempo real, a possibilidade de auto-ajuste, e principalmente, ao contrário da Lógica Fuzzy, a possibilidade de ser treinada sem a 
necessidade de um especialista.

As RNA oferecem boa abordagem para problemas que requeiram: reconhecimento, associação ou classificação de padrões. No trabalho de ANDRADE e CARVALHO ${ }^{[129]}$ são apresentadas 50 diferentes aplicações já implementadas, em segmentos que variam como: Administração, Química, Medicina, Controle de Qualidade, Linhas de Produção, Segurança e Telecomunicações. Para exemplificar uma aplicação corriqueira das RNA's, podemos citar o sistema de reconhecimento de placas de veículos.

\subsubsection{IMPLEMENTAÇÃO DE REDES NEURAIS ARTIFICIAIS}

Não existe uma metodologia comprovadamente melhor para implementação de uma RNA. PEDROZA e PEDREIRA ${ }^{[131]}$ apresentam uma metodologia de treinamento para as redes baseada em operadores de extensão enquanto DINIZ ${ }^{[128]}$, em seu trabalho lista os principais parâmetros que ficarão a cargo do conhecimento prévio do projetista. Entre estes parâmetros a autora cita as seguintes escolhas:

- número de camadas ("layers");

- número de neurônios por camada;

- topologia das interconexões;

- funções de transferência nas diferentes camadas;

- taxa de aprendizado (a mudança nos pesos durante o treinamento da rede);

- constante de momentum (valor que avalia convergência para evitar mínimos locais);

- representação dos dados;

- dinâmica de treinamento, verificação e operação.

Todos estes fatores estão correlacionados: o aumento do número de camadas, por exemplo, implica em um aumento da complexidade e conseqüientemente do tempo de processamento. Um pequeno número de camadas pode fazer com que a RNA não tenha a flexibilidade necessária para a generalização, mas por outro lado um número excessivo pode fazer com que a RNA “decore” os dados ao invés de generalizá-los. 
SILVA e OLIVEIRA ${ }^{[132]}$, apresentam em seu trabalho uma discussão sobre a configuração de RNA visando dimensionar corretamente os números de neurônios e camadas.

Segundo estes autores, uma única camada escondida seria suficiente para problemas de reconhecimento de caracteres, enquanto recomendam a utilização de duas camadas para os problemas de estimação de funções. O número de neurônios da camada escondida é sugerido entre: média aritmética entre as entradas e saídas da rede, média geométrica, ou um décimo da quantidade de exemplos disponíveis para treinamento.

Para a taxa de aprendizado (learning rate) e fator de inércia (momentum) os valores recomendados por estes autores são 0,4 e 0,3 respectivamente. Neste trabalho, os autores destacam que estes valores são orientativos, mas são o ponto de partida para evitar que a rede tenha excesso de capacidade de armazenamento de dados e perca com isso a capacidade de generalização, problema conhecido como overfitting, ou que não tenha armazenamento suficiente para fazer uma generalização, problema conhecido como underfitting. Uma rede com underfitting não reconhece adequadamente os dados enquanto uma rede com overfitting reconhece apenas os dados do conjunto de treinamento a que foi submetida, ou seja "decora" os resultados.

Esta liberdade na concepção e implementação tem seus aspectos positivos e negativos. Por positivo podemos destacar a liberdade dada ao projetista para que ajuste a RNA para cada aplicação individualmente. Por negativo, destaca-se a experiência necessária por parte do mesmo, como um fator determinante para o sucesso da aplicação.

Nesta tese é utilizada uma RNA multilayer perceptron com backpropagation operando com a metodologia desenvolvida por RAMALHO et a ${ }^{[133]}$ que consiste em construir um programa de computador onde várias RNAs testam entre um limite superior e um inferior pré-estabelecidos os valores de neurônios e demais parâmetros para a melhor configuração da rede.

As múltiplas possibilidades na implementação e os diversos tipos de pré- 
processamento aplicáveis aos dados acabam por dar condições para que se desenvolvam RNAs mais adaptadas a resolução de problemas, e outras menos adaptadas. Isto justifica a comparação de rendimento entre diferentes RNA, ou entre a mesma RNA com diferentes configurações para a resolução de um mesmo problema.

\subsubsection{RNA MULTILAYER PERCEPTRON COM BACKPROPAGATION}

Conforme HAYKIN, S. ${ }^{[125]}$, o perceptron é uma forma construtiva de RNA para padrões linearmente separáveis. Foi proposto em 1958 por Rosenblatt como sendo o primeiro modelo de aprendizagem supervisionada.

É constituído de um único neurônio com um polarizador conhecido como bias e um peso sináptico ajustável. A limitação de um perceptron construído por um único neurônio é exatamente classificar os padrões em apenas duas hipóteses. A classificação em mais que dois planos cria a necessidade de mais neurônios, de onde vem o nome multilayer perceptron (MLP). Uma ilustração do perceptron é observada na figura 29.

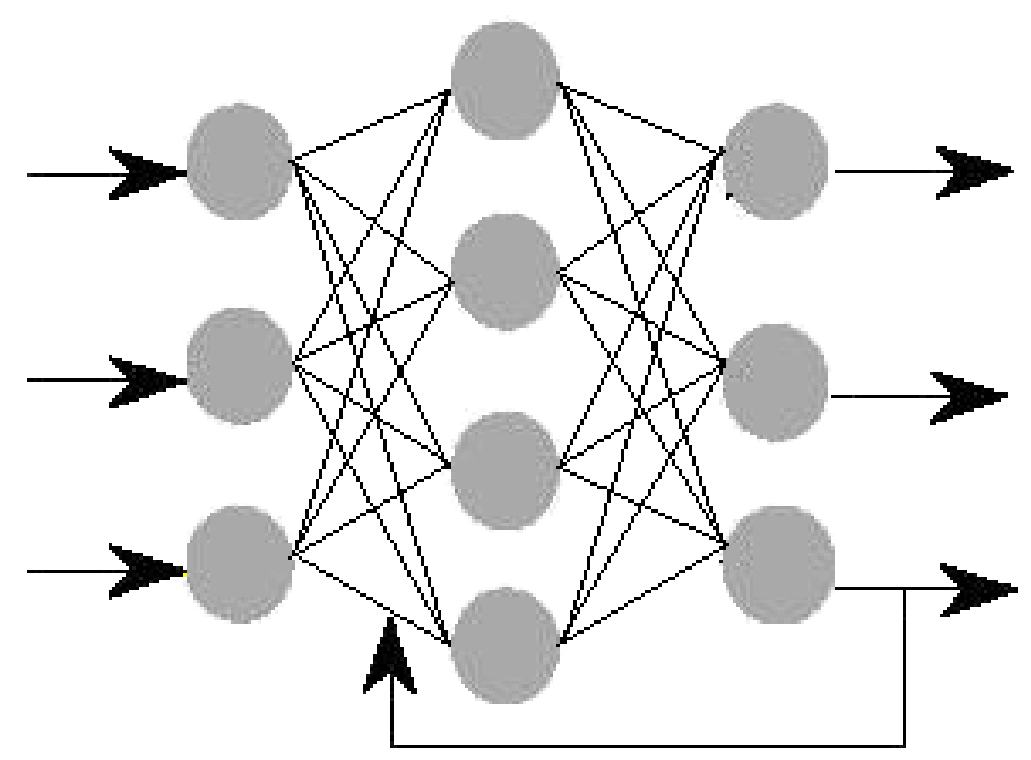

Figura 29 - Esquema de uma RNA MLP com retropropagação do sinal adaptada de ${ }^{[121]}$ 
Um MLP é um perceptron com mais que uma camada de neurônios, o que lhe possibilita classificar padrões de $\mathrm{n}$ diferentes grupos, desde que respeitada a regra de que a informação a processar seja linearmente separável em n grupos, ou seja, não é suficiente que a informação esteja distinta, é necessário também, que as condições de contorno e proximidade permitam uma separação linear, como pode ser visto na figura 30 .

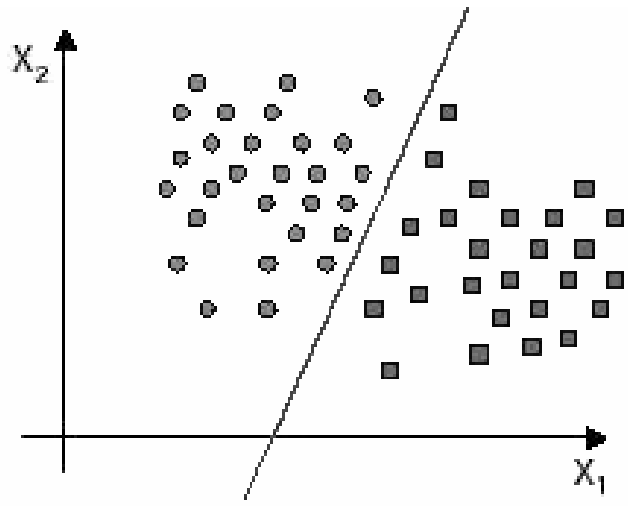

Linearmente separável

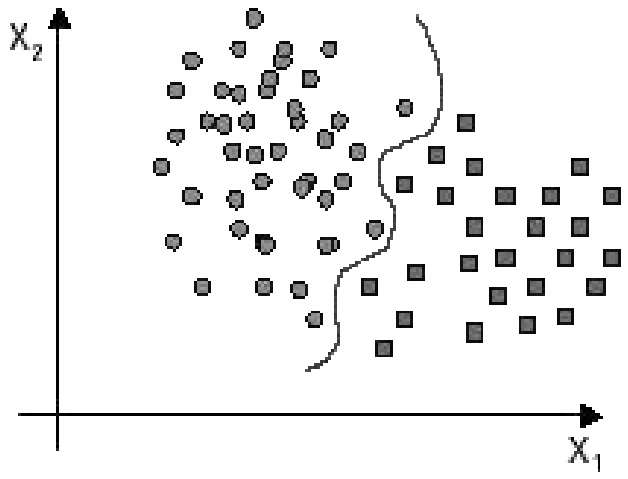

Nâo-linearmente separável

Figura 30 - Planos linearmente separáveis e não separáveis ${ }^{[126]}$

Num MLP, podemos destacar claramente uma camada de neurônios de entrada, uma ou mais camadas intermediárias, que são denominadas camadas ocultas, e a camada de saída. Uma vez alimentada a rede, o sinal se propaga para frente e vai alimentando as demais camadas sucessivamente.

É possível, porém alterar uma rede MLP, que tem por característica ser de aprendizagem supervisionada, para o sistema de auto-aprendizagem por correção de erro. Isto cria a necessidade de envio de sinal no sentido inverso através da utilização de um artifício conhecido como retropropagação (backpropagation). A retropropagação funciona baseada no algoritmo de filtragem adaptativa através do cálculo de, por exemplo, a soma do erro mínimo quadrado médio. Este sinal é enviado no sentido inverso, fazendo com que os neurônios das camadas intermediárias recebam informações nos dois sentidos, tendo assim condição de monitorar a própria aprendizagem. O passo adiante é a propagação, enquanto que o passo no sentido inverso ao fluxo da rede é a retropropagação. 
Conforme DE CARVALHO et $\mathrm{al}^{[134]}$, na propagação os pesos aplicados aos neurônios não sofrem alteração, enquanto que na retropropagação, devido a existir a possibilidade de comparação entre a resposta obtida e a esperada, há a possibilidade de um coeficiente de alteração ser aplicado no peso, aprimorando-o. Este processo de aprendizado é conhecido como aprendizagem por retropropagação.

\subsubsection{COMPARAÇÃO DE DESEMPENHO ENTRE REDES NEURAIS}

Visando comparar a eficiência das diferentes redes, ou de uma mesma com diferentes arquiteturas construtivas, diversos autores têm proposto abordagens comparativas. A seguir é apresentado um resumo das abordagens de comparação das estudadas:

DIETTERICH ${ }^{[135]}$ mostra em seu trabalho uma metodologia, onde propõe separar em três os tipos de dados para avaliação e treinamento das redes: dados reais, realísticos e sintéticos e discute sobre qual destes dados deve ser utilizado para as tarefas de aprimoramento ou comparação entre redes.

FLEXER $^{[136]}$ apresenta em seu trabalho os requisitos mínimos necessários para uma avaliação comparativa entre redes. Primeiro separa os diferentes tópicos a serem analisados: como analisar a configuração da rede em si, com a verificação da influência da escolha de cada parâmetro, e como analisar estatisticamente os dados gerados por uma rede. Para esta segunda avaliação este autor propõe uma fórmula onde o desvio padrão dos resultados corretos é analisado.

PRECHELT $^{[137]}$ apresenta em seu trabalho diferentes abordagens de testes de redes aplicadas em diferentes aplicações finais. O artigo comenta as particularidades da RNA aplicadas as áreas médica, química e biológica, e ressalta os aspectos da escolha da função de ativação, a inicialização dos pesos sinápticos e o critério adotado para o encerramento do treinamento. 
DIETTERICH $^{[138]}$ em outro trabalho apresenta uma descrição entre cinco métodos para avaliação comparativa entre redes. Entre estes métodos aparece o teste de McNemar, onde é proposta a construção de uma tabela de duas linhas e duas colunas com os resultados corretos e incorretos identificados pelas duas redes na diagonal principal e os identificados por uma das RNA e não pela outra na diagonal. Esta abordagem permite explorar com clareza a questão do falso positivo, ou seja, o que uma rede identificou como falso o que é verdadeiro e vice-versa.

RAMALHO et al ${ }^{[133]}$ propõem em seu trabalho uma nova metodologia para a comparação de redes neurais denominada IAR (Índice de Avaliação de Redes) onde são atribuídos pesos para os erros de acordo com as conseqüências do erro e ponderando sua probabilidade de ocorrência, tópico este que não é abordado pelos demais pesquisadores.

\subsection{COMBINAÇÃO DA REGRESSÃO MÚLTIPLA COM RNA}

Enquanto a técnica de Redes Neurais Artificiais tem uma excelente resposta em aplicações de reconhecimento de padrões e capacidade de aprendizado, a regressão linear múltipla reproduz mais fielmente um fenômeno.

Os conjuntos de parâmetros tanto de entrada como de saída do processo oxicorte podem ser tratados estatisticamente tanto para aplicação de uma como de outra destas técnicas.

A utilização de Redes Neurais Artificiais (RNA) soluciona os problemas da regressão, pois não tem por objetivo reproduzir fielmente o fenômeno e sim generalizá-lo. Além disto, contrariamente a uma regressão linear, uma RNA tem capacidade de aprendizado.

Comparando Redes Neurais Artificiais com modelamento matemático por regressão linear RAMALHO, ISSA E BRANDI ${ }^{[139]}$ mostram em seu trabalho que em experimentos com pequenos lotes, as RNAs apresentam melhor capacidade de generalização enquanto o modelamento matemático através de regressões lineares múltiplas pode reproduzir o comportamento de um processo com mais fidelidade. 


\section{RESULTADOS E DISCUSSÃO}

Realizados os ensaios com as técnicas e materiais descritos anteriormente, foi feita então a caracterização e a medição das peças para o levantamento de dados. Para facilitar a compreensão dos resultados que serão apresentados e discutidos a seguir, as tabelas serão sempre mostradas com as identificações da temperatura de pré-aquecimento e da concentração do oxigênio utilizado. A concentração de 99,5\% algumas vezes é referida como industrial (ou IND), enquanto que a concentração de $99,95 \%$ é referida como ultrapura (UP).

\subsection{TAXA DE MATERIAL REMOVIDA POR PEÇA}

Foram feitas as pesagens iniciais e finais dos corpos de prova no mesmo equipamento e foi adotado o procedimento de três pesagens por peça e considerada a média dos valores obtidos. Os valores da massa removida estão os apresentados na tabela 12 .

TABELA 12 - MASSA DE MATERIAL REMOVIDA POR PEÇA

\begin{tabular}{|c|c|c|c|c|c|c|}
\hline $\begin{array}{c}\mathrm{n}^{0} \\
\text { peça }\end{array}$ & $\begin{array}{c}\text { Esp } \\
(\mathrm{mm})\end{array}$ & $\begin{array}{c}\text { Pré aq } \\
\left({ }^{\circ} \mathrm{C}\right)\end{array}$ & $\begin{array}{c}\text { Conc. } \\
\mathrm{O}_{2}(\%)\end{array}$ & $\begin{array}{c}\text { Média das 3 } \\
\text { pesagens iniciais }(\mathrm{g})\end{array}$ & $\begin{array}{c}\text { Média das 3 } \\
\text { pesagens finais }(\mathrm{g})\end{array}$ & $\begin{array}{c}\text { Massa } \\
\text { removida (g) }\end{array}$ \\
\hline 11 & 12,7 & 39,5 & 99.95 & 1853,00 & 1798,7 & 54,30 \\
\hline 2 & 12,7 & 29,3 & 99,50 & 1861,33 & 1807,0 & 54,30 \\
\hline 12 & 12,7 & 288,9 & 99,95 & 1855,00 & 1801,2 & 53,80 \\
\hline 1 & 12,7 & 291,3 & 99,50 & 1853,00 & 1800,1 & 52,93 \\
\hline $9 \mathrm{p}$ & 25,4 & 39,8 & 99,95 & 3456,33 & 3345,0 & 111,33 \\
\hline $6 \mathrm{p}$ & 25,4 & 40,1 & 99,50 & 3458,00 & 3347,5 & 110,53 \\
\hline $7 \mathrm{p}$ & 25,4 & 274,5 & 99.95 & 3481,67 & 3375,2 & 106,47 \\
\hline $1 \mathrm{p}$ & 25,4 & 289,1 & 99,50 & 3453,33 & 3349,0 & 104,37 \\
\hline $8 \mathrm{~m}$ & 38,1 & 26,9 & 99.95 & 5455,00 & 5273,2 & 181,83 \\
\hline $12 \mathrm{~m}$ & 38,1 & 26,5 & 99,50 & 5444,33 & 5258,6 & 185,73 \\
\hline $7 \mathrm{~m}$ & 38,1 & 257,5 & 99.95 & 5435,00 & 5272,4 & 162,57 \\
\hline $5 \mathrm{~m}$ & 38,1 & 242,8 & 99,50 & 5447,00 & 5284,0 & 162,97 \\
\hline $8 \mathrm{~g}$ & 50,4 & 37,5 & 99.95 & 7458,00 & 7244,4 & 213,60 \\
\hline $14 \mathrm{~g}$ & 50,4 & 29,8 & 99,50 & 7459,00 & 7244,0 & 214,97 \\
\hline $7 \mathrm{~g}$ & 50,4 & 238,8 & 99.95 & 7338,33 & 7142,8 & 195,50 \\
\hline $1 \mathrm{~g}$ & 50,4 & 237,3 & 99,50 & 7459,67 & 7246,6 & 213,07 \\
\hline
\end{tabular}


Para se analisar comparativamente o material removido de diferentes chapas não se pode levar em conta apenas a diferença de peso entre a peça antes e após o corte, uma vez que um corte nunca é exatamente reto. Há sempre alguma inclinação por menor que seja (em relação ao eixo z) e também sempre algum desalinhamento em relação à superfície lateral da chapa (em relação aos eixos x e y). Com esta constatação entende-se que nunca se esta cortando o cateto, mas sim a hipotenusa. Desta maneira, com o auxilio de uma mesa de desempeno, foram medidas as dimensões "comprimento real do corte nos eixos xy" (ao invés do comprimento da chapa cortada) e o "espessura real do corte na dimensão z" (ao invés da espessura da chapa cortada).

De posse destas dimensões foi calculada a área real de corte, já considerando as pequenas inclinações, e este valor foi então dividido pela massa de material removido para calcular a taxa de remoção efetiva de material, conforme é apresentado na tabela 13.

TABELA 13 - REMOÇÃO EFETIVA DE MATERIAL POR PEÇA

\begin{tabular}{|c|c|c|c|c|c|c|c|c|}
\hline $\begin{array}{c}\mathrm{n}^{0} \\
\text { peça }\end{array}$ & $\begin{array}{l}\text { esp } \\
(\mathrm{mm})\end{array}$ & $\begin{array}{c}\text { pre } \\
\text { aqcm. } \\
\left({ }^{\circ} \mathrm{C}\right)\end{array}$ & $\begin{array}{l}\text { conc. } \\
\mathrm{O}_{2}(\%)\end{array}$ & $\begin{array}{c}\text { Comprimento } \\
\text { real de corte } \\
(\mathrm{mm})\end{array}$ & $\begin{array}{c}\text { Espessura } \\
\text { real (mm) }\end{array}$ & $\begin{array}{c}\text { Área real } \\
\left(\mathrm{mm}^{2}\right)\end{array}$ & $\begin{array}{c}\text { Remoção } \\
\text { (g) }\end{array}$ & $\begin{array}{c}\text { Taxa de } \\
\text { remoção } \\
\left(\mathrm{g} / \mathrm{mm}^{2}\right) \times 10 \\
\end{array}$ \\
\hline 11 & 12,7 & 39,5 & 99.95 & 200,25 & 12,6 & 2532,56 & 54,30 & 2,1441 \\
\hline 2 & 12,7 & 29,3 & 99,50 & 200,75 & 12,6 & 2538,03 & 54,30 & 2,1395 \\
\hline 12 & 12,7 & 288,9 & 99,95 & 201,22 & 12,6 & 2537,08 & 53,80 & 2,1206 \\
\hline 1 & 12,7 & 291,3 & 99,50 & 200,33 & 12,6 & 2523,27 & 52,93 & 2,0978 \\
\hline $9 p$ & 25,4 & 39,8 & 99,95 & 200,12 & 25,2 & 5040,41 & 111,33 & 2,2088 \\
\hline $6 p$ & 25,4 & 40,1 & 99,50 & 200,22 & 25,2 & 5048,26 & 110,53 & 2,1895 \\
\hline $7 p$ & 25,4 & 274,5 & 99.95 & 201,68 & 25,2 & 5083,47 & 106,47 & 2,0944 \\
\hline $1 p$ & 25,4 & 289,1 & 99,50 & 199,38 & 25,2 & 5029,66 & 104,37 & 2,0750 \\
\hline $8 m$ & 38,1 & 26,9 & 99.95 & 201,92 & 38,1 & 7697,74 & 162,57 & 2,1119 \\
\hline $12 \mathrm{~m}$ & 38,1 & 26,5 & 99,50 & 201,90 & 38,1 & 7701,58 & 185,73 & 2,4116 \\
\hline $7 \mathrm{~m}$ & 38,1 & 257,5 & 99.95 & 202,03 & 38,2 & 7708,41 & 181,83 & 2,3589 \\
\hline $5 m$ & 38,1 & 242,8 & 99,50 & 202,07 & 38,1 & 7697,45 & 162,97 & 2,1172 \\
\hline $8 g$ & 50,4 & 37,5 & 99.95 & 202,43 & 50,8 & 10279,07 & 213,60 & 2,0780 \\
\hline $14 \mathrm{~g}$ & 50,4 & 29,8 & 99,50 & 201,53 & 51,1 & 10289,28 & 214,97 & 2,0892 \\
\hline $7 g$ & 50,4 & 238,8 & 99.95 & 200,87 & 50,4 & 10129,53 & 195,50 & 1,9300 \\
\hline $1 \mathrm{~g}$ & 50,4 & 237,3 & 99,50 & 202,05 & 51,0 & 10296,49 & 213,07 & 2,0693 \\
\hline
\end{tabular}

Obs. Os valores de "espessura real" apresentados com valores menores que o valor da fração de polegada são relativos a chapas que, embora fornecidas com espessura nominal em fração de polegada, encontravam-se na verdade com espessura abaixo deste valor. 
Como pode ser observado, as chapas cortadas em temperatura ambiente apresentam uma tendência a uma taxa de remoção de material maior que as chapas cortadas com préaquecimento, o que sugere que a temperatura exerce maior influência na taxa de remoção de material do que a concentração do oxigênio. Este resultado contraria o senso comum que supõe que numa chapa pré-aquecida tem-se mais calor, logo a quantidade de material removido deve ser maior.

Com o objetivo de separar a influência de cada um dos tratamentos no resultado da taxa de oxidação, estes foram separados de acordo com seus valores médios para serem adequadamente analisados. Os resultados são apresentados na tabela 14.

TABELA 14 - ANÁLISE DA TAXA DE REMOÇÃO DO MATERIAL

\begin{tabular}{|c|c|c|c|c|c|c|c|c|c|}
\hline $\begin{array}{c}n^{0} \\
\text { peça }\end{array}$ & $\begin{array}{c}\text { esp } \\
(\mathrm{mm})\end{array}$ & $\begin{array}{l}\text { T. pré } \\
\text { aquec. } \\
\left({ }^{\circ} \mathrm{C}\right)\end{array}$ & $\begin{array}{l}\text { Conc } \\
\mathrm{O}_{2}(\%)\end{array}$ & $\begin{array}{c}\text { Taxa de } \\
\text { remoção } \\
\left(\mathrm{g} / \mathrm{mm}^{2}\right) \times 10 \\
\end{array}$ & $\begin{array}{c}\text { Remoção média } \\
\text { na espessura } \\
\left(\mathrm{g} / \mathrm{mm}^{2}\right) \times 10 \\
\end{array}$ & $\begin{array}{l}\text { Média cl } \\
\text { pré } \\
\text { aquec. }\end{array}$ & $\begin{array}{l}\text { Média } \\
\text { s/ pré } \\
\text { aquec. }\end{array}$ & $\begin{array}{l}\text { Média } \\
\mathrm{O}_{2} \text { IND }\end{array}$ & $\begin{array}{l}\text { Média } \\
\mathrm{O}_{2} \text { UP }\end{array}$ \\
\hline 11 & 12,7 & 39,5 & 99.95 & 2,1441 & \multirow{4}{*}{2,126} & \multirow{4}{*}{2,109} & \multirow{4}{*}{2,141} & \multirow{4}{*}{2,118} & \multirow{4}{*}{2,132} \\
\hline 2 & 12,7 & 29,3 & 99,50 & 2,1395 & & & & & \\
\hline 12 & 12,7 & 288,9 & 99,95 & 2,1206 & & & & & \\
\hline 1 & 12,7 & 291,3 & 99,50 & 2,0978 & & & & & \\
\hline $9 p$ & 25,4 & 39,8 & 99,95 & 2,2088 & \multirow{4}{*}{2,142} & \multirow{4}{*}{2,084} & \multirow{4}{*}{2,199} & \multirow{4}{*}{2,132} & \multirow{4}{*}{2,151} \\
\hline $6 p$ & 25,4 & 40,1 & 99,50 & 2,1895 & & & & & \\
\hline $7 p$ & 25,4 & 274,5 & 99.95 & 2,0944 & & & & & \\
\hline $1 p$ & 25,4 & 289,1 & 99,50 & 2,0750 & & & & & \\
\hline $8 \mathrm{~m}$ & 38,1 & 26,9 & 99.95 & 2,1119 & \multirow{4}{*}{2,250} & \multirow{4}{*}{2,238} & \multirow{4}{*}{2,261} & \multirow{4}{*}{2,264} & \multirow{4}{*}{2,235} \\
\hline $12 m$ & 38,1 & 26,5 & 99,50 & 2,4116 & & & & & \\
\hline $7 \mathrm{~m}$ & 38,1 & 257,5 & 99.95 & 2,3589 & & & & & \\
\hline $5 \mathrm{~m}$ & 38,1 & 242,8 & 99,50 & 2,1172 & & & & & \\
\hline $8 \mathrm{~g}$ & 50,4 & 37,5 & 99.95 & 2,0780 & \multirow{4}{*}{2,042} & \multirow{4}{*}{1,999} & \multirow{4}{*}{2,083} & \multirow{4}{*}{2,079} & \multirow{4}{*}{2,004} \\
\hline $14 \mathrm{~g}$ & 50,4 & 29,8 & 99,50 & 2,0892 & & & & & \\
\hline $7 \mathrm{~g}$ & 50,4 & 238,8 & 99.95 & 1,9300 & & & & & \\
\hline $1 \mathrm{~g}$ & 50,4 & 237,3 & 99,50 & 2,0693 & & & & & \\
\hline
\end{tabular}

De posse destas informações é possível então agrupá-las num único gráfico onde a influência de cada fator pode ser individualmente analisada. A figura 31 mostra as variações obtidas. 
Como pode ser observado, as chapas cortadas em temperatura ambiente tem por tendência apresentar a maior taxa de remoção de material. Porém, para além da influência da temperatura observa-se a variação da taxa de remoção de material em função da concentração do oxigênio de corte utilizado. Enquanto nas espessuras menores as maiores taxas de remoção são obtidas nos cortes em temperatura ambiente e com a utilização de oxigênio ultra puro, nas chapas grossas as maiores remoções são observadas nos cortes também em temperatura ambiente porém com a utilização de oxigênio industrial, sendo que a transição ocorre por volta do valor de $32 \mathrm{~mm}$ de espessura.

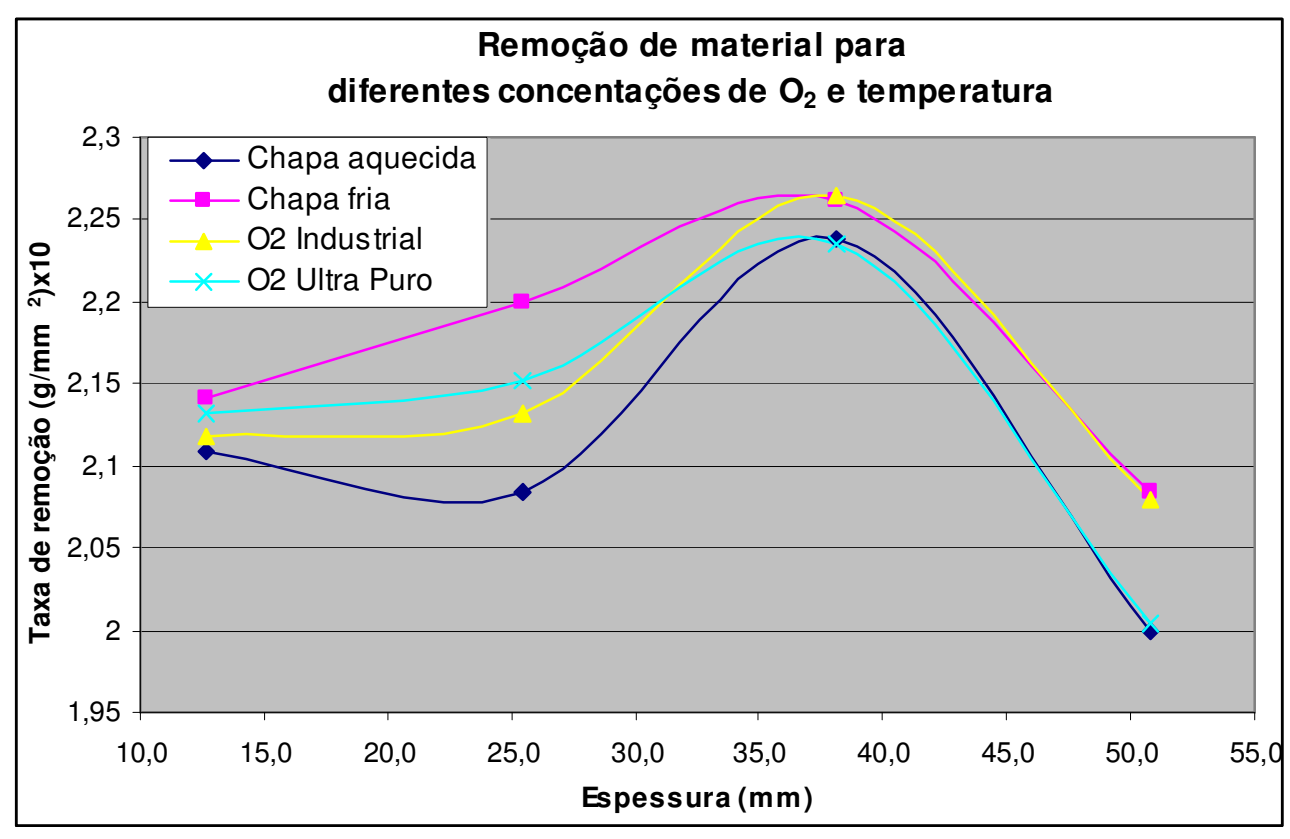

Figura 31 - Variações médias na taxa de remoção de material

Estes resultados podem ser explicados considerando-se que a principal fonte de fornecimento de calor vai mudando da chama de pré-aquecimento do maçarico para a reação química de oxidação do ferro do aço na medida em que se aumenta a espessura. Como a reação é dependente de calor para que continue ocorrendo, faz então sentido que a taxa de remoção aumente com o aumento da espessura, uma vez que uma maior quantidade de calor vai sendo produzida quando se oxida mais material e este fica disponível para a reação favorecendo-a e causando, assim, um aumento na taxa de oxidação.

O aumento do volume de material oxidado também causa aumento da quantidade 
fumos e gases produzidos $\left(\mathrm{CO}, \mathrm{CO}_{2}, \mathrm{NO}, \mathrm{NO}_{2}\right)$ e estes serão produzidos em volumes maiores na medida em que houver maior disponibilidade de oxigênio, como acontece quando se utiliza o oxigênio de alta concentração. Por esta razão observa-se no gráfico que nas espessuras maiores o oxigênio de alta concentração apresenta menor taxa de oxidação que o oxigênio industrial, contrariamente às espessuras menores.

A contaminação ${ }^{[50]}$ do oxigênio pelos gases formados $\left(\mathrm{CO}, \mathrm{CO}_{2}, \mathrm{NO}, \mathrm{NO}_{2}\right)$ é um fato que há tempos é apresentado no processo como limitante para o aumento da velocidade de corte nas maiores espessuras. Uma das soluções propostas para contornar este problema é a utilização de um segundo jato de oxigênio com a função de cortina protetora do oxigênio de corte e. desta maneira, reduzindo a contaminação pelo ar. Esta tecnologia, conhecida como bico "cortina", foi apresentada na figura $5^{[66]}$. A idéia básica desta solução é manter o jato de corte central responsável pela oxidação, adicionar um jato externo a este para a expulsão dos contaminantes gasosos produzidos no processo, e a manutenção dos orifícios externos a furação normal para a saída da mistura do combustível com o oxigênio para a chama. É uma solução tecnicamente interessante e que, economicamente, necessita análise econômica criteriosa para ser implementada, pois se por um lado propicia substancial aumento na velocidade de corte nas chapas de maiores espessuras, por outro gera aumento no consumo de oxigênio.

A chapa aquecida sempre apresentará menores taxas de remoção de material, uma vez que nesta a quantidade de energia necessária para atingir a temperatura de oxidação viva é menor e a reação é mais rápida. Seu gradiente térmico é menor e o calor dissipa-se mais lentamente no local onde é aplicado, porém o jato de oxigênio rapidamente expulsa os óxidos formados, cessando assim a produção de calor.

No caso da chapa fria ocorre o oposto, a quantidade de energia para atingir a temperatura de oxidação viva é maior, o gradiente de temperatura é mais abrupto, o calor dissipa-se mais rapidamente na chapa fria e a reação é mais lenta. Com isto, mais material é oxidado, aumentando assim a taxa de oxidação.

Estes dois fatores atuam sinergicamente, podendo-se pressupor que, um mesmo 
diâmetro interno do bico de corte apresentará, com o aumento da espessura, taxa de remoção cada vez menor.

Um outro dado que chama atenção é o fato que a menor geração de calor é uma evidência de que a reação ocorre mais rapidamente. No oxicorte, a velocidade da reação é ditada pelo avanço do maçarico em relação à peça, produzindo menos calor por reagir mais rapidamente. Por não avançar suficientemente rápido, o oxigênio de corte passa pela sangria já aberta sem reagir. Neste trabalho, as velocidades de corte foram mantidas as mesmas para efeito de pesquisa e comparação nas diferentes espessuras, e este tópico analisa a taxa de remoção de material e não a velocidade de oxidação. Obviamente em um estudo que contemplasse a velocidade de oxidação ao invés de sua taxa, apresentaria como conclusão que a utilização no jato de corte de oxigênio de maior concentração permite que se opere com maiores velocidades de corte em relação ao corte utilizando oxigênio de menor concentração.

Em relação à diminuição da necessidade do calor com o aumento da espessura, este fato é ainda corroborado pela seguinte evidência prática descrita a seguir.

$\mathrm{Na}$ medida em que se aumenta a espessura, a necessidade de fornecimento de energia não aumenta proporcionalmente. Por exemplo: quando se aumenta a espessura de $10 \mathrm{~mm}$ para $100 \mathrm{~mm}$, ocorre um aumento de dez vezes, mas nem a vazão de gás requerida, nem a pressão aumentam dez vezes assim como a velocidade também não diminui em 10

vezes. É feita apenas a alteração do bico de corte para um que tenha um canal de oxigênio de corte maior, visando expulsar o maior volume de óxidos que será produzido. A abertura para a passagem dos gases da chama é muitas vezes a mesma, pois alguns bicos, como o modelo utilizado neste trabalho, são feitos em duas peças distintas e troca-se apenas o inserto interno com a furação do jato de oxigênio para corte, porém a área da saída dos gases de chama é exatamente a mesma.

\subsection{COMPOSIÇÃO QUÍMICA DOS ÓXIDOS PRODUZIDOS}

Para a realização das análises por difração de raios $\mathrm{X}(\mathrm{DRX})$ pelo método de pó, 
idealmente o material deve ser pulverizado em frações passantes a $0,074 \mathrm{~mm}$, em operação controlada para evitar o excesso de geração de fumos. O material é em seguida fixado no porta-amostras garantindo assim uma superfície plana e horizontal (figura 31).

Na DRX a identificação de fases pode, em alguns casos, ser realizada com confiabilidade técnica em condições de granulometria e montagem da amostra distintas das ideais, entretanto, para análises quantitativas a qualidade da preparação é fundamental para a obtenção de resultados tecnicamente confiáveis.

As amostras estudadas continham a presença de material dúctil, que na cominuição formou finas placas com dimensões superiores a granulometria de $0,074 \mathrm{~mm}$, ficando assim em condições inadequadas para a análise quantitativa. Estas placas mostraram-se compostas essencialmente de Fe metálico e mostraram-se dúcteis permanecendo sem redução de tamanho na cominuição praticada, mesmo após três sucessivas operações.

Com base no observado, foi feita a separação das diferentes frações: a retida a 0,074 mm contendo apenas Fe metálico e a fração passante a $0,074 \mathrm{~mm}$ na qual foi empregada a metodologia de Rietveld para determinação e quantificação das fases presentes. O resultado final de cada amostra foi gerado por balanço de massa como apresentado na tabela 15 .

Os resultados mostram os teores de wustita (48 a 66\%), magnetita (12 a 38\%), ferro metálico (7 a 31\%). Com exceção ao ferro metálico, observa-se que todas as outras fases constituintes aparecem predominantemente concentradas na fração abaixo de 0,074 mm. A quantificação de tal fração é considerada bastante precisa pelo índice de qualidade do próprio software que avalia a qualidade do ajuste entre o difractograma real e o proposto, o que garante a confiabilidade aos resultados. A fração retida em 0,074 mm correspondeu a um valor entre 14,0 a $30,1 \%$ em massa das amostras.

No ensaio foram também encontrados traços de outras fases como $\mathrm{Fe}_{2} \mathrm{O}_{3}$ (hematita), $\mathrm{FeO}\left(\mathrm{OH}\right.$ ) (Goethita), $\mathrm{MnO}_{2}$ (Akhtenskita), $\mathrm{Na}_{0,3} \mathrm{Fe}_{2} \mathrm{Si}_{4} \mathrm{O}_{10}(\mathrm{OH})_{2} \cdot 4 \mathrm{H}_{2} \mathrm{O}$ (Nontronita) e $\mathrm{Fe}_{2,719} \mathrm{O}_{4} \mathrm{Si}_{0,281}$ (óxido de $\mathrm{Fe}$ e $\mathrm{Si}$ ), mas em quantidades muito pequenas (menores que 3\%), que tanto por ficarem no limiar de confiabilidade da técnica de DRX, quanto pelo fato de que as somas de todas estas fases terem sido menores que 5\%, foram por isto desprezadas. 
TABELA 15 - BALANÇO DE MASSA E QUANTIFICAÇÃO FINAL

\begin{tabular}{|c|c|c|c|c|c|c|c|c|c|c|}
\hline \multirow{2}{*}{$\begin{array}{c}\mathrm{n}^{0} \\
\text { peça }\end{array}$} & \multirow{2}{*}{$\begin{array}{l}\text { esp } \\
(\mathrm{mm})\end{array}$} & \multirow{2}{*}{$\begin{array}{c}\text { pre } \\
\text { aqcm. } \\
\left({ }^{\circ} \mathrm{C}\right)\end{array}$} & \multirow{2}{*}{$\begin{array}{l}\text { Conc } \\
\mathrm{O}_{2}(\%)\end{array}$} & \multirow{2}{*}{$\begin{array}{c}\text { fração } \\
\text { granulométrica }\end{array}$} & \multirow{2}{*}{$\begin{array}{c}\% \text { massa } \\
\text { na } \\
\text { amostra }\end{array}$} & wustita & $\begin{array}{l}\text { Magnetit } \\
\text { a }\end{array}$ & hematita & goethita & $\mathrm{Fe}$ \\
\hline & & & & & & $(\mathrm{FeO})$ & $\left(\mathrm{Fe}_{3} \mathrm{O}_{4}\right)$ & $\left(\mathrm{Fe}_{2} \mathrm{O}_{3}\right)$ & $(\mathrm{FeOOH})$ & (Fe) \\
\hline \multirow[t]{3}{*}{11} & 12,7 & 39,5 & 99.95 & $+0,074 \mathrm{~mm}$ & 24,6 & & & & & 100 \\
\hline & & & & $-0,074 \mathrm{~mm}$ & 75,4 & 79 & 18 & $<1$ & 2 & $<1$ \\
\hline & & & & total & 100 & 60 & 14 & $<1$ & 2 & 25 \\
\hline \multirow[t]{3}{*}{2} & 12,7 & 29,3 & 99,50 & $+0,074 \mathrm{~mm}$ & 9,33 & & & & & 100 \\
\hline & & & & $-0,074 \mathrm{~mm}$ & 90,7 & 57 & 40 & 2 & 0 & 0 \\
\hline & & & & total & 100 & 52 & 36 & 2 & 0 & 9 \\
\hline \multirow[t]{3}{*}{12} & 12,7 & 288,9 & 99,95 & $+0,074 \mathrm{~mm}$ & 30,1 & & & & & 100 \\
\hline & & & & $-0,074 \mathrm{~mm}$ & 69,9 & 80 & 18 & 3 & 0 & $<1$ \\
\hline & & & & total & 100 & 56 & 13 & 2 & 0 & 31 \\
\hline \multirow[t]{3}{*}{1} & 12,7 & 291,3 & 99,50 & $+0,074 \mathrm{~mm}$ & 14,0 & & & & & 100 \\
\hline & & & & $-0,074 \mathrm{~mm}$ & 86,0 & 60 & 38 & $<1$ & $<1$ & 0 \\
\hline & & & & total & 100 & 52 & 33 & $<1$ & $<1$ & 14 \\
\hline \multirow[t]{3}{*}{$9 p$} & 25,4 & 39,8 & 99,95 & $+0,074 \mathrm{~mm}$ & 23,2 & & & & & 100 \\
\hline & & & & $-0,074 \mathrm{~mm}$ & 76,8 & 81 & 16 & 3 & 0 & 0 \\
\hline & & & & total & 100 & 62 & 12 & 2 & 0 & 23 \\
\hline \multirow[t]{3}{*}{$6 p$} & 25,4 & 40,1 & 99,50 & $+0,074 \mathrm{~mm}$ & 15,3 & & & & & 100 \\
\hline & & & & $-0,074 \mathrm{~mm}$ & 84,7 & 65 & 33 & 2 & 0 & $<1$ \\
\hline & & & & total & 100 & 55 & 28 & 2 & 0 & 16 \\
\hline \multirow[t]{3}{*}{$7 p$} & 25,4 & 274,5 & 99.95 & $+0,074 \mathrm{~mm}$ & 18,3 & & & & & 100 \\
\hline & & & & $-0,074 \mathrm{~mm}$ & 81,7 & 65 & 32 & 3 & 0 & $<1$ \\
\hline & & & & total & 100 & 53 & 26 & 2 & 0 & 19 \\
\hline \multirow[t]{3}{*}{$1 p$} & 25,4 & 289,1 & 99,50 & $+0,074 \mathrm{~mm}$ & 10,0 & & & & & 100 \\
\hline & & & & $-0,074 \mathrm{~mm}$ & 90,0 & 57 & 42 & 2 & 0 & 0 \\
\hline & & & & total & 100 & 51 & 38 & 2 & 0 & 10 \\
\hline \multirow[t]{3}{*}{$8 m$} & 38,1 & 26,9 & 99.95 & $+0,074 \mathrm{~mm}$ & 7,21 & & & & & 100 \\
\hline & & & & $-0,074 \mathrm{~mm}$ & 92,8 & 61 & 37 & 2 & $<1$ & 0 \\
\hline & & & & total & 100 & 57 & 34 & 2 & $<1$ & 7 \\
\hline \multirow[t]{3}{*}{$12 m$} & 38,1 & 26,5 & 99,50 & $+0,074 \mathrm{~mm}$ & 23,2 & & & & & 100 \\
\hline & & & & $-0,074 \mathrm{~mm}$ & 76,8 & 69 & 29 & $<1$ & $<1$ & $<1$ \\
\hline & & & & total & 100 & 53 & 22 & $<1$ & $<1$ & 24 \\
\hline \multirow[t]{3}{*}{$7 \mathrm{~m}$} & 38,1 & 257,5 & 99.95 & $+0,074 \mathrm{~mm}$ & 15,7 & & & & & 100 \\
\hline & & & & $-0,074 \mathrm{~mm}$ & 84,3 & 62 & 36 & 2 & $<1$ & $<1$ \\
\hline & & & & total & 100 & 52 & 30 & 2 & $<1$ & 17 \\
\hline \multirow[t]{3}{*}{$5 m$} & 38,1 & 242,8 & 99,50 & $+0,074 \mathrm{~mm}$ & 16,3 & & & & & 100 \\
\hline & & & & $-0,074 \mathrm{~mm}$ & 83,7 & 79 & 21 & 0 & $<1$ & 0 \\
\hline & & & & total & 100 & 66 & 18 & 0 & $<1$ & 16 \\
\hline \multirow[t]{3}{*}{$8 \mathrm{~g}$} & 50,4 & 37,5 & 99.95 & $+0,074 \mathrm{~mm}$ & 15,6 & & & & & 100 \\
\hline & & & & $-0,074 \mathrm{~mm}$ & 84,4 & 72 & 27 & 2 & $<1$ & 0 \\
\hline & & & & total & 100 & 61 & 23 & 2 & $<1$ & 16 \\
\hline $14 \mathrm{~g}$ & 50,4 & 29,8 & 99,50 & $+0,074 \mathrm{~mm}$ & 16,7 & & & & & 100 \\
\hline & & & & $-0,074 \mathrm{~mm}$ & 83,3 & 77 & 22 & $<1$ & $<1$ & 0 \\
\hline & & & & total & 100 & 64 & 18 & $<1$ & $<1$ & 17 \\
\hline $7 g$ & 50,4 & 238,8 & 99.95 & $+0,074 \mathrm{~mm}$ & 9,09 & & & & & 100 \\
\hline & & & & $-0,074 \mathrm{~mm}$ & 90,9 & 65 & 33 & 2 & 0 & 0 \\
\hline & & & & total & 100 & 59 & 30 & 2 & 0 & 9 \\
\hline $1 \mathrm{~g}$ & 50,4 & 237,3 & 99,50 & $+0,074 \mathrm{~mm}$ & 21,1 & & & & & 100 \\
\hline & & & & $-0,074 \mathrm{~mm}$ & 78,9 & 61 & 36 & 3 & 0 & $<1$ \\
\hline & & & & total & 100 & 48 & 28 & 2 & 0 & 22 \\
\hline
\end{tabular}


Cada amostra foi analisada de acordo com uma seqüência específica de ajustes de parâmetros que foram sucessivamente refinados paralelamente à verificação dos resultados. O índice de medição para a qualidade deste ajuste é a verificação do valor de GOF (goodness-of-fit) e a análise da qualidade dos gráficos obtidos para aferição da eficiência do refinamento. Como referência o GOF é um valor entre 0 e 30 indicando o melhor ajuste no valor mínimo. Foi adotado o procedimento de trabalhar no refinamento até todos os ensaios obtivessem o valor de GOF máximo menor do que um.

A Figura 32 ilustra um difratograma refinado pelo método de Rietveld, com as fases identificadas e o ajuste entre os perfis observado (em vermelho) e o calculado (em azul), permitindo a quantificação da fração abaixo de $0,074 \mathrm{~mm}$ da amostra.

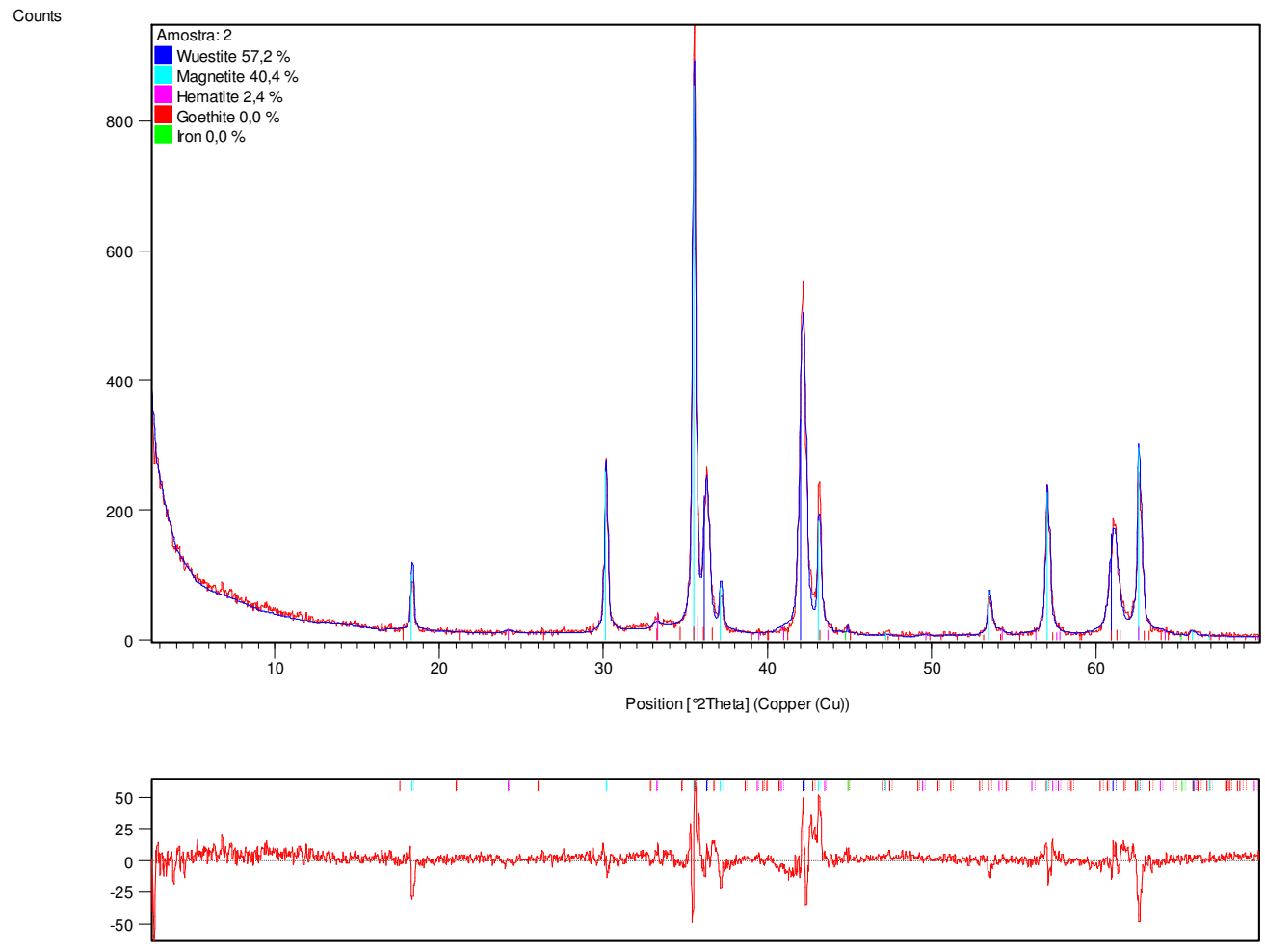

Figura 32 - Padrão difractométrico refinado pelo método de Rietveld (amostra 2)

Foi feito o estudo visando estabelecer relações matemáticas entre os tratamentos estudados, nomeadamente a variação da temperatura de pré-aquecimento e a concentração do oxigênio, com os teores de óxidos obtidos visando equacionar ou mesmo quantificar a 
relação entre estes. Os resultados destas correlações situam-se na faixa entre 0,009 e 0,79, valores que numa correlação entre 0 e 1 não são suficientes para se estabelecer uma relação matematicamente segura que pudesse ser representada, por exemplo por uma equação, que representasse com boa margem de confiança a influência dos tratamentos sobre os resultados.

Apesar desta baixa correlação, quando se reordena os dados da tabela 15 em ordem decrescente tanto do teor de magnetita quanto do teor de Fe observa-se que estes são bastante influenciados pela concentração de $\mathrm{O}_{2}$ utilizado, e muito pouco pela temperatura de pré-aquecimento das chapas. Este fato pode ser observado na tabela 16 onde são apresentados ordenadamente o teor de Fe metálico na esquerda e o teor de magnetita na direita.

TABELA 16 - RELAÇÃO ENTRE OS ÓXIDOS E OS TRATAMENTOS

\begin{tabular}{|c|c|c|c|c|c|c|c|c|c|}
\hline Chapa & $\begin{array}{c}\mathrm{e} \\
(\mathrm{mm})\end{array}$ & $\begin{array}{c}\text { T. pré } \\
\left({ }^{\circ} \mathrm{C}\right)\end{array}$ & $\begin{array}{c}\text { Conc } \\
\mathrm{O}_{2}(\%) \\
\end{array}$ & $\% \mathrm{Fe}$ & Chapa & $\begin{array}{c}\mathrm{e} \\
(\mathrm{mm})\end{array}$ & $\begin{array}{l}\text { T. pré } \\
\left({ }^{\circ} \mathrm{C}\right)\end{array}$ & $\begin{array}{l}\text { Conc } \\
\mathrm{O}_{2}(\%) \\
\end{array}$ & $\%$ magnetita \\
\hline 12 & 12 & 288,9 & 99,95 & 31 & $1 \mathrm{P}$ & 25 & 289,1 & 99,5 & 38 \\
\hline 11 & 12 & 39,5 & 99,95 & 25 & 2 & 12 & 29,3 & 99,5 & 36 \\
\hline $8 \mathrm{M}$ & 38 & 26,9 & 99,95 & 24 & $12 \mathrm{M}$ & 38 & 26,5 & 99,5 & 34 \\
\hline 9P & 25 & 39,8 & 99,95 & 23 & 1 & 12 & 291,3 & 99,5 & 33 \\
\hline $7 \mathrm{G}$ & 50 & 238,8 & 99,95 & 22 & $5 \mathrm{M}$ & 38 & 242,8 & 99,5 & 30 \\
\hline $7 \mathrm{P}$ & 25 & 274,5 & 99,95 & 19 & $1 \mathrm{G}$ & 50 & 237,3 & 99,5 & 30 \\
\hline $5 \mathrm{M}$ & 50 & 37,5 & 99,95 & 17 & $7 G$ & 25 & 40,1 & 99,5 & 28 \\
\hline $8 \mathrm{G}$ & 38 & 242,8 & 99,5 & 17 & $6 \mathrm{P}$ & 50 & 238,8 & 99,95 & 28 \\
\hline $6 \mathrm{P}$ & 38 & 257,5 & 99,95 & 16 & $7 \mathrm{P}$ & 25 & 274,5 & 99,95 & 26 \\
\hline $7 \mathrm{M}$ & 25 & 40,1 & 99,5 & 16 & $14 G$ & 50 & 29,8 & 99,5 & 23 \\
\hline $14 \mathrm{G}$ & 50 & 29,8 & 99,5 & 16 & $8 \mathrm{M}$ & 38 & 26,9 & 99,95 & 22 \\
\hline 1 & 12 & 291,3 & 99,5 & 14 & $8 \mathrm{G}$ & 50 & 37,5 & 99,95 & 18 \\
\hline $1 \mathrm{P}$ & 25 & 289,1 & 99,5 & 10 & $7 \mathrm{M}$ & 38 & 257,5 & 99,95 & 18 \\
\hline 2 & 12 & 29,3 & 99,5 & 9 & 11 & 12 & 39,5 & 99,95 & 14 \\
\hline $1 G$ & 50 & 237,3 & 99,5 & 9 & 12 & 12 & 288,9 & 99,95 & 13 \\
\hline $12 \mathrm{M}$ & 38 & 26,5 & 99,5 & 7 & $9 \mathrm{P}$ & 25 & 39,8 & 99,95 & 12 \\
\hline
\end{tabular}

Nesta tabela observa-se que ordenando os teores de Fe em ordem decrescente, nas nove primeiras chapas encontram-se as oito cortadas com o oxigênio de maior concentração (UP). Por outro lado na direita da tabela, quando se faz a mesma avaliação do teor de 
magnetita, as sete primeiras chapas com os maiores teores deste óxido foram cortadas com o oxigênio de menor concentração (IND).

A concentração dos maiores teores de magnetita nas chapas que foram cortadas com o oxigênio industrial é explicável pelo fato de que este óxido funde em maior temperatura e como discutido no tópico 5.1 as chapas cortadas com oxigênio de menor concentração, são as que apresentam a reação mais lenta e as que atingem a maior temperatura.

Já os teores de $\mathrm{Fe}$, embora apresentem esta forte relação com a concentração do oxigênio utilizado, na verdade este fato não explica sozinho a variação do teor de $\mathrm{Fe}$ metálico na escória. A fusão da borda superior da superfície oxidada também o influencia, como será mostrado no item 5.3.

A hematita, apesar de citada como presente nos óxidos em alguns trabalhos ${ }^{[2,23,48]}$ foi desprezada para este estudo, sustentada pelos argumentos de que está muito próxima dos limites inferiores de detecção da técnica utilizada e, devido a esta dúvida, pela confirmação através de um ensaio complementar utilizando a técnica de espectroscopia de Mossbauer, que foi realizado para a eliminação desta suspeita e que veio a confirmar a virtual ausência deste óxido.

É importante citar que a quantificação pelo método de Rietveld consiste na criação de um perfil simulado onde diversos ajustes são feitos visando aproximar o perfil simulado proposto do perfil real. A seqüência que os ajustes são feitos, juntamente com a sensibilidade do operador, são determinantes para o sucesso desta metodologia.

Como este trabalho desenvolveu uma metodologia de ajustes especialmente para a quantificação de óxidos de ferro ${ }^{[119]}$, a utilização dos testes complementares por espectroscopia de Mossbauer veio a confirmar que a técnica mostra-se adequada e a metodologia de refinamento proposta pode ser efetivada como um recurso confiável para a quantificação de óxidos de Fe.

Com o objetivo de validar a metodologia de quantificação da composição química 
dos óxidos por DRX e com a utilização do método de Rietveld, foram feitas 3 chapas com alguns dos tratamentos utilizados nesta tese, nomeadamente: utilização do oxigênio industrial em chapa pré-aquecida e oxigênio ultra-puro em chapas frias pré-aquecidas, que foram cortadas em extensão suficiente para produção de óxidos em quantidade que possibilitasse realizar ensaios com as duas técnicas. Os resultados destes ensaios foram comparados pelas duas técnicas de análise e estão apresentados na tabela 17.

TABELA 17 - COMPARAÇÃO ENTRE ANÁLISE DE ÓXIDOS POR DRX E POR ESPECTROSCOPIA MOSSBAUER

\begin{tabular}{|c|c|c|c|c|c|}
\hline \multirow{2}{*}{ Conc. $\mathrm{O}_{2}(\%)$} & \multirow{2}{*}{$\begin{array}{c}\text { Temp } \\
\text { pré }\left({ }^{\circ} \mathrm{C}\right)\end{array}$} & \multicolumn{2}{|c|}{$\mathrm{DRX}+$ Rietveld } & \multicolumn{2}{c|}{ Espectroscopia Mossbauer } \\
\cline { 3 - 6 } & & $\mathrm{Fe}_{3} \mathrm{O}_{4}$ & $\mathrm{FeO}$ & $\mathrm{Fe}_{3} \mathrm{O}_{4}$ & $\mathrm{FeO}$ \\
\hline 99,50 & 230 & 15,73 & 84,21 & 14,69 & 85,26 \\
\hline 99,95 & 30 & 21,63 & 78,33 & 20,60 & 79,36 \\
\hline 99,95 & 230 & 10,24 & 89,69 & 9,98 & 89,88 \\
\hline
\end{tabular}

Estes ensaios foram feitos apenas com a fração passante, pois a montagem do pó para a técnica de Mossbauer é muito semelhante a DRX. Em conseqüência disto, os resultados não apresentam valores de Fe puro, o que veio a confirmar a virtual ausência deste na fração passante, o mesmo acontecendo com a hematita, confirmando assim a presença apenas de $\mathrm{FeO}$ e $\mathrm{Fe}_{3} \mathrm{O}_{4}$ nas amostras analisadas com os tratamentos realizados.

A menor soma dos resultados é a da chapa pré aquecida com a utilização de oxigênio ultra puro, que apresenta o valor de 99,86, ou seja, uma incerteza de ensaio (ou possibilidade de ser hematita ou $\mathrm{Fe}$ ) de apenas $0,14 \%$, valor este que é quase 10 vezes inferior ao limite de precisão da própria técnica que é de $1 \%$.

\subsection{ESTIMATIVA DO TEOR DE FERRO NA ESCÓRIA DE OXICORTE}

Embora o oxicorte seja um processo de oxidação de metais e com isto o esperado seja que a composição da escória apresente basicamente óxidos, alguns autores ${ }^{[2,10,23]}$ citam $^{2}$ a presença de Fe puro na escória, afirmando que este pode ser resultado de arraste, microfusões ou arrancamento. 
Embora citado no item 5.2 que o teor de Fe da escória tenha boa correlação com a concentração do oxigênio utilizado no corte, foi também investigada uma outra razão que pode explicar a presença do $\mathrm{Fe}$, ou seja, a fusão de área da parte superior da superfície cortada, que foi dimensionada conforme os tópicos 5.3.1 e 5.3.2 apresentados a seguir.

\subsubsection{MEDIÇÃO DA ESPESSURA DA REGIÃO FUNDIDA}

A região fundida localiza-se na parte superior da superfície cortada. Ela existe devido à proximidade da chama, sendo também um indicativo da boa regulagem do processo uma vez que quando seu valor é excessivo é clara indicação de que há excesso de calor, podendo este ser causado por: potência da chama muito alta, distância bico-peça muito pequena ou velocidade de corte muito baixa. Nesta tese, estes 3 parâmetros foram rigorosamente mantidos iguais, o que fez com que toda variação encontrada nesta dimensão fosse exclusivamente causada pelas variações na concentração do $\mathrm{O}_{2}$, da temperatura de pré-aquecimento das chapas ou pelas diferentes espessuras da peça.

As superfícies cortadas foram analisadas no estereoscópio, onde foi feita a medição desta dimensão, como é observado na figura 33.

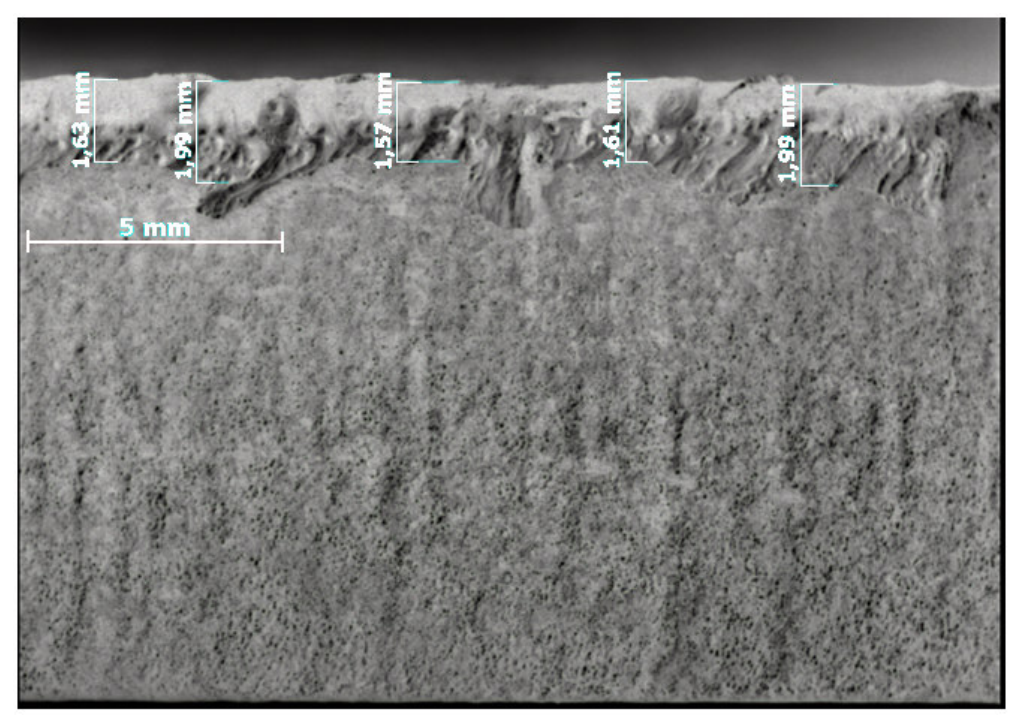

Figura 33 - Medição da região fundida na borda superior 
Devido a grande variação encontrada, foi feita a medição em 5 pontos com análise criteriosa do desvio padrão antes da adoção da média nos cálculos posteriores. Os valores medidos são apresentados na tabela 18. A tabela também apresenta uma coluna que mostra a porcentagem da região fundida na borda superior da chapa cortada em relação a espessura nominal das chapas.

TABELA 18 - ESPESSURA DA REGIÃO FUNDIDA

\begin{tabular}{|c|c|c|c|c|c|c|c|c|c|c|c|}
\hline \multirow[b]{2}{*}{ Chapa } & \multirow[b]{2}{*}{$\begin{array}{c}\mathrm{e} \\
(\mathrm{mm})\end{array}$} & \multirow[b]{2}{*}{$\begin{array}{c}\text { T. pré } \\
\left({ }^{\circ} \mathrm{C}\right)\end{array}$} & \multirow[b]{2}{*}{$\begin{array}{c}\text { Conc } \mathrm{O}_{2} \\
(\%)\end{array}$} & \multicolumn{5}{|c|}{ Medida } & \multirow[b]{2}{*}{ Média } & \multirow{2}{*}{$\begin{array}{c}\text { Desv. } \\
\text { Padrão }\end{array}$} & \multirow{2}{*}{$\begin{array}{c}\% \text { da } \\
\text { região } \\
\text { fundida }\end{array}$} \\
\hline & & & & 1 & 2 & 3 & 4 & 5 & & & \\
\hline 11 & 12,7 & 39,5 & 99,95 & 3,01 & 3,01 & 2,71 & 3,15 & 2,61 & 2,90 & 0,20 & 22,8 \\
\hline 2 & 12,7 & 29,3 & 99,50 & 1,63 & 1,99 & 1,57 & 1,61 & 1,99 & 1,76 & 0,19 & 13,9 \\
\hline 12 & 12,7 & 288,9 & 99,95 & 3,09 & 2,98 & 3,03 & 2,91 & 2,91 & 2,98 & 0,07 & 23,5 \\
\hline 1 & 12,7 & 291,3 & 99,50 & 1,87 & 1,65 & 1,55 & 1,79 & 1,67 & 1,71 & 0,11 & 13,5 \\
\hline $9 \mathrm{P}$ & 25,4 & 39,8 & 99,95 & 4,36 & 4,08 & 4,33 & 4,03 & 3,80 & 4,12 & 0,21 & 16,2 \\
\hline $6 \mathrm{P}$ & 25,4 & 40,1 & 99,50 & 3,18 & 3,29 & 2,75 & 3,08 & 3,46 & 3,15 & 0,24 & 12,4 \\
\hline $7 \mathrm{P}$ & 25,4 & 274,5 & 99,95 & 4,84 & 4,74 & 4,87 & 4,74 & 4,61 & 4,76 & 0,09 & 18,7 \\
\hline $1 \mathrm{P}$ & 25,4 & 289,1 & 99,50 & 2,20 & 3,16 & 3,66 & 3,36 & 3,22 & 3,12 & 0,49 & 12,3 \\
\hline $8 M$ & 38,1 & 26,9 & 99,95 & 4,68 & 5,03 & 4,76 & 4,80 & 4,72 & 4,80 & 0,12 & 12,6 \\
\hline $12 \mathrm{M}$ & 38,1 & 26,5 & 99,50 & 2,76 & 2,60 & 2,40 & 2,38 & 2,48 & 2,52 & 0,14 & 6,6 \\
\hline $7 \mathrm{M}$ & 38,1 & 257,5 & 99,95 & 4,32 & 4,36 & 4,44 & 3,96 & 4,40 & 4,30 & 0,17 & 11,3 \\
\hline $5 \mathrm{M}$ & 38,1 & 242,8 & 99,50 & 4,83 & 4,76 & 4,44 & 4,36 & 4,76 & 4,63 & 0,19 & 12,2 \\
\hline $8 G$ & 50,4 & 37,5 & 99,95 & 3,63 & 3,57 & 3,47 & 3,95 & 3,53 & 3,63 & 0,17 & 7,2 \\
\hline $14 G$ & 50,4 & 29,8 & 99,50 & 5,49 & 5,33 & 5,43 & 5,40 & 5,17 & 5,36 & 0,11 & 10,6 \\
\hline $7 \mathrm{G}$ & 50,4 & 238,8 & 99,95 & 5,11 & 5,08 & 4,98 & 5,08 & 4,91 & 5,03 & 0,08 & 10,0 \\
\hline $1 \mathrm{G}$ & 50,4 & 237,3 & 99,50 & 5,04 & 4,82 & 4,82 & 4,88 & 5,04 & 4,92 & 0,10 & 9,8 \\
\hline
\end{tabular}

Os resultados mostraram que para uma mesma concentração de oxigênio e temperatura de chapa, a região fundida da borda superior da chapa cortada tende a aumentar com o aumento de espessura, conforme mostra a figura 34. Da mesma maneira, quando se aumenta a temperatura da chapa e mantendo-se a pureza do gás, a região fundida da borda superior da chapa cortada tende a aumentar com o aumento de espessura. Este resultado pode estar relacionado com o volume de material que é oxidado, gerando uma maior quantidade de calor na região do corte. A comparação entre as duas concentrações de oxigênio de corte mostra que o industrial $(99,5 \%)$ apresenta uma região fundida menor que o ultra-puro $(99,95 \%)$. A figura 35 ilustra este comportamento. Nela foram calculados os 
valores médios, para cada um das variáveis utilizadas por espessura de chapa.

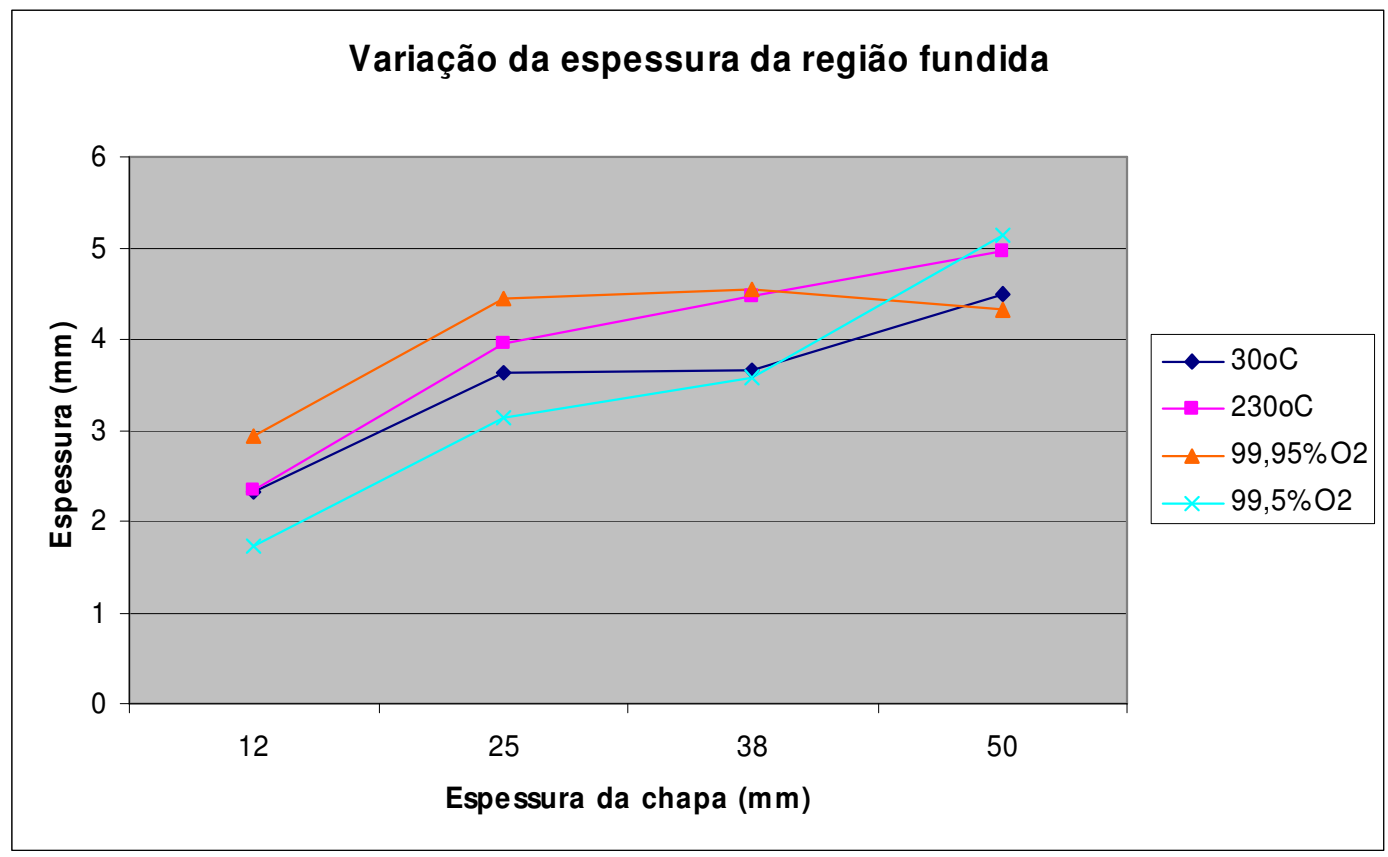

Figura 34 - Dimensão de região fundida relativa à espessura da chapa em função das condições experimentais utilizadas

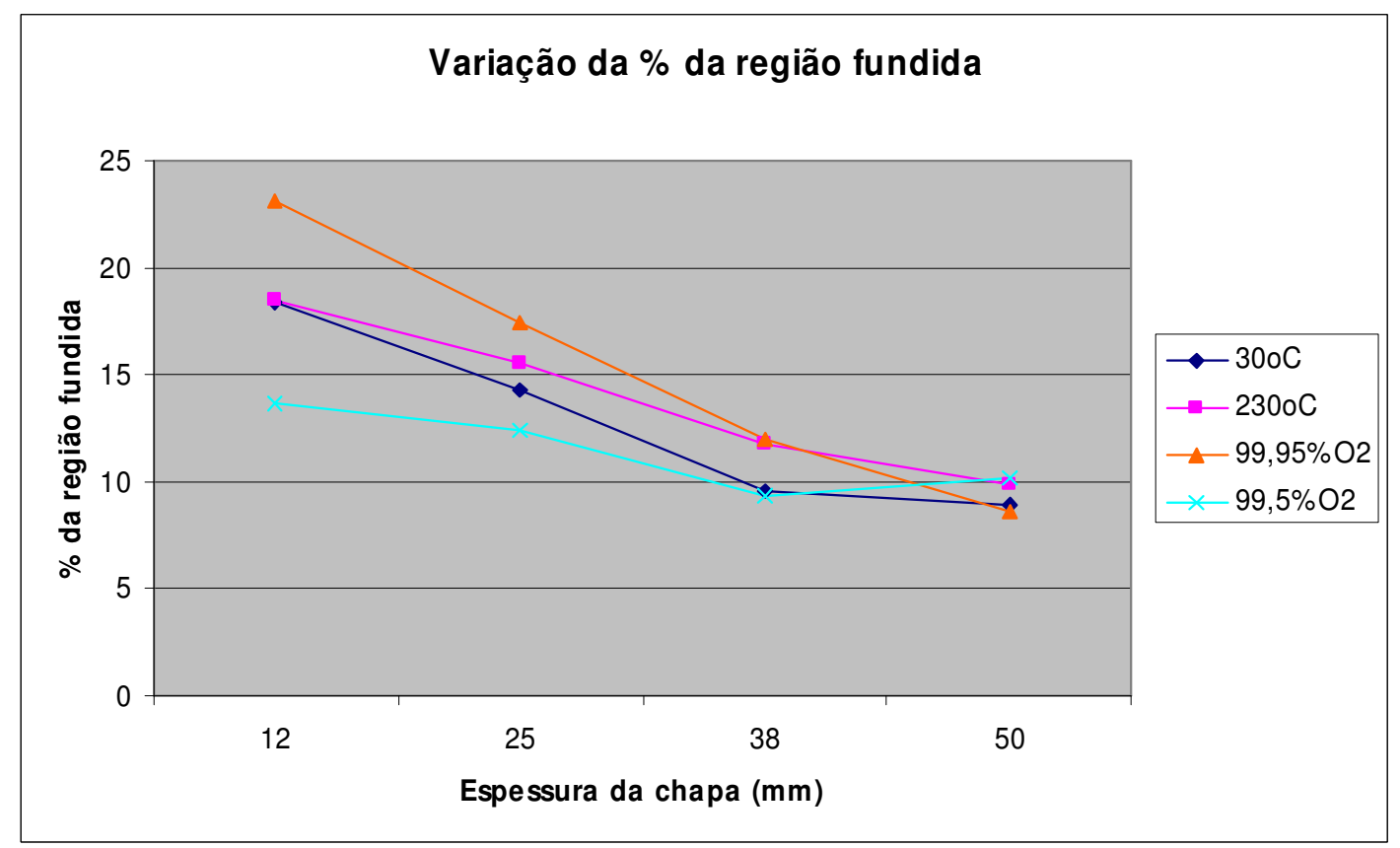

Figura 35 - Porcentagem da região fundida relativa à espessura da chapa em função das condições experimentais utilizadas 
Por outro lado, quando se observa a porcentagem relativa da região fundida da borda superior da chapa cortada em relação à espessura nominal, a porcentagem vai diminuindo com o aumento da espessura. Este fato indica que o calor da chama de aquecimento influencia cada vez menos no processo de oxicorte, enquanto que a oxidação torna-se cada vez mais importante para o processo.

Com relação à quantidade de ferro na escória os valores são comparáveis, uma vez que a quantidade deste elemento relaciona-se diretamente com a espessura da região fundida da borda superior da chapa cortada. A tabela 19 mostra a comparação entre os valores obtidos por análise química e os valores por fusão da borda superior da chapa.

TABELA 19 - COMPARAÇÃO ENTRE AS PORCENTAGENS DE Fe

\begin{tabular}{|c|c|c|c|c|c|c|}
\hline $\mathbf{n}^{\mathbf{0}}$ & $\begin{array}{c}\mathbf{e} \\
(\mathbf{m m})\end{array}$ & $\begin{array}{c}\text { T. pré } \\
\left({ }^{\circ} \mathbf{C}\right)\end{array}$ & $\begin{array}{c}\mathbf{O}_{\mathbf{2}} \\
(\mathbf{\%})\end{array}$ & $\begin{array}{c}\text { \% da } \\
\text { região } \\
\text { fundida }\end{array}$ & $\begin{array}{c}\text { \%Fe na } \\
\text { escória }\end{array}$ & $\begin{array}{c}\text { \% da diferença do } \\
\text { teor de Fe }\end{array}$ \\
\hline 11 & 12,6 & 39,5 & 99.95 & 22,8 & 25,0 & 8,8 \\
\hline 2 & 12,6 & 29,3 & 99,50 & 13,9 & 9,0 & $-54,4$ \\
\hline 12 & 12,6 & 288,9 & 99,95 & 23,5 & 31,0 & 24,2 \\
\hline 1 & 12,6 & 291,3 & 99,50 & 13,5 & 14,0 & 3,6 \\
\hline 9P & 25,2 & 39,8 & 99,95 & 16,2 & 23,0 & 29,6 \\
\hline $6 \mathrm{P}$ & 25,2 & 40,1 & 99,50 & 12,4 & 16,0 & 22,5 \\
\hline $7 \mathrm{P}$ & 25,2 & 274,5 & 99,95 & 18,7 & 19,0 & 1,6 \\
\hline 1P & 25,2 & 289,1 & 99,50 & 12,3 & 10,0 & $-23,0$ \\
\hline $8 \mathrm{M}$ & 38,1 & 26,9 & 99.95 & 12,6 & 7,0 & $-80,0$ \\
\hline 12M & 38,1 & 26,5 & 99,50 & 6,6 & 24,0 & 72,5 \\
\hline $7 \mathrm{M}$ & 38,2 & 257,5 & 99.95 & 11,3 & 17,0 & 33,5 \\
\hline $5 \mathrm{M}$ & 38,1 & 242,8 & 99,50 & 12,2 & 16,0 & 23,8 \\
\hline $8 \mathrm{G}$ & 50,8 & 37,5 & 99.95 & 7,2 & 16,0 & 55,0 \\
\hline 14G & 51,1 & 29,8 & 99,50 & 10,6 & 17,0 & 37,6 \\
\hline $7 \mathrm{G}$ & 50,4 & 238,8 & 99.95 & 10,0 & 9,0 & $-11,1$ \\
\hline 1G & 51,0 & 237,3 & 99,50 & 9,8 & 22,0 & 55,5 \\
\hline
\end{tabular}

É evidente que existe uma parte do ferro obtido na escória que é oriundo da fusão da borda superior da chapa, cujo metal líquido gerado é arrastado pelo jato de oxigênio de corte. Mas esta não é a única fonte de produção de ferro na escória. O ferro pode ser gerado pelo efeito abrasivo do jato de oxigênio no ferro aquecido durante o corte, pela redução localizada da temperatura de fusão do aço devido à microssegregação, por reações químicas que produzam ferro como um dos seus subprodutos ou até com a fusão localizada do aço, 
dependendo da temperatura liquidus do mesmo e da temperatura de corte. Nas chapas mais finas o teor de Fe é principalmente relacionado com a dimensão da fusão da borda superior das chapas. À medida que a espessura é aumentada, a participação de outras fontes de ferro na escória começa a ter efeito, como o ferro arrastado através da espessura por abrasão ou em locais que existam inclusões ou microssegregações que reduzam localmente a temperatura de fusão do aço e, consequentemente, aproximando-a da temperatura de fusão dos óxidos de ferro. A figura 36 compara os teores de ferro gerados pela fusão da borda e os valores obtidos por análise química.
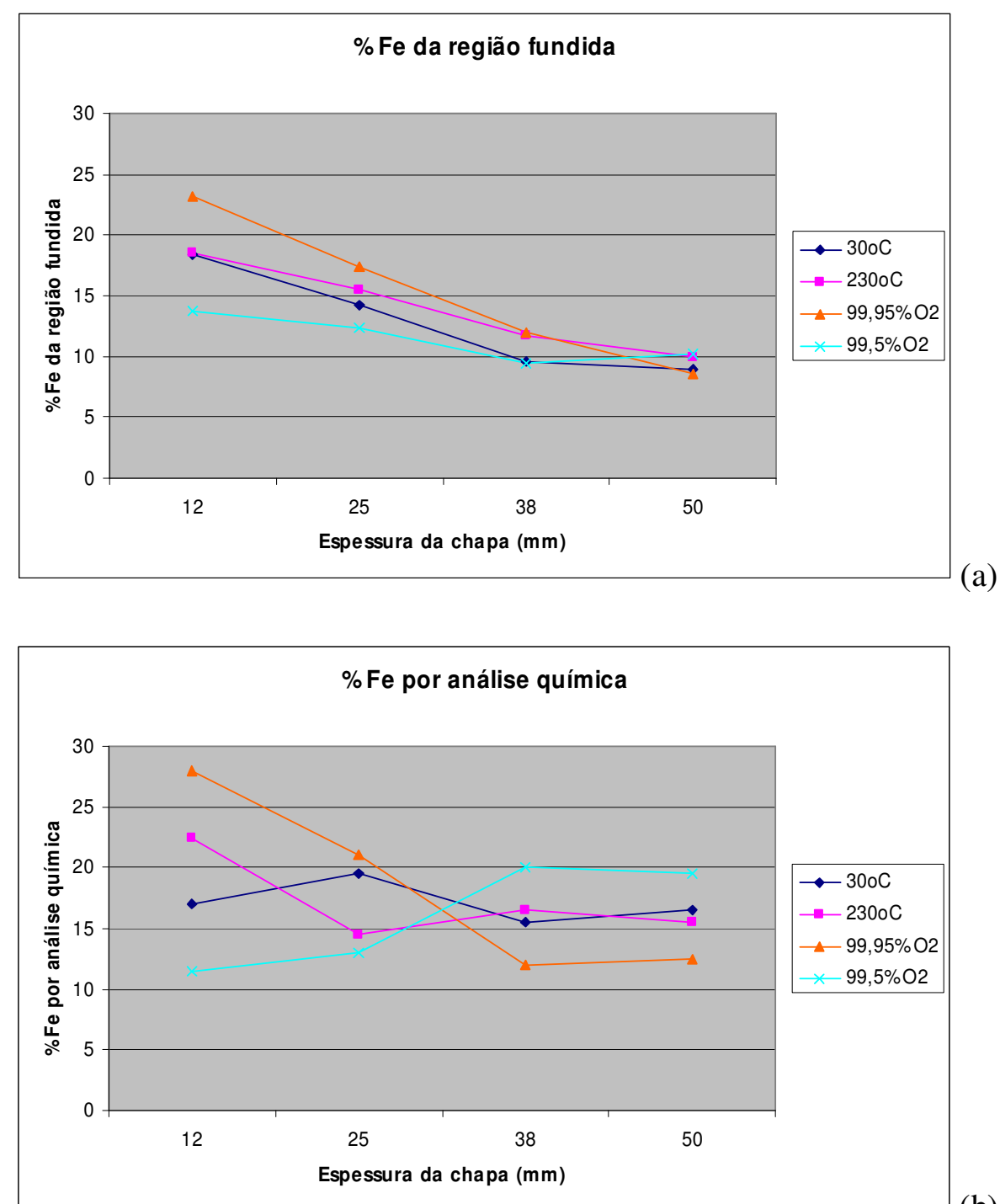

(b)

Figura 36 - Comparação entre os teores de ferro na escória do oxicorte. Em (a) os valores obtidos pela espessura da região fundida e em (b) porcentagem da região fundida relativa à espessura da chapa em função das condições experimentais utilizadas 
Outro fator importante a ser considerado é a quantidade de calor produzida pela reação do ferro com o oxigênio. Como a velocidade de corte foi mantida constante, a quantidade de calor gerada é função do volume de material oxidado, isto é, pelo aumento da espessura da chapa. Neste caso, o arraste de material seria preponderante à fusão da borda da chapa.

\subsubsection{MEDIÇÃO DA LARGURA DA SANGRIA}

Como a peça após ser cortada não possibilita de ter sua sangria medida, pois as duas metades se separam, a medição da largura da sangria foi realizada por diferença de massa e confirmada por experimentos em chapa cortada com os mesmos parâmetros, onde o corte foi interrompido e a sangria preservada. Os valores da largura da sangria obtidos são apresentados na tabela 20 .

TABELA 20 - VALORES CALCULADOS PARA A

LARGURA DA SANGRIA

\begin{tabular}{|c|c|c|c|c|}
\hline $\mathbf{n}^{\mathbf{0}}$ & $\begin{array}{c}\mathbf{e} \\
(\mathbf{m m})\end{array}$ & $\begin{array}{c}\text { Temperatura } \\
\text { pré aq. }\left({ }^{\circ} \mathbf{C}\right)\end{array}$ & $\begin{array}{c}\mathbf{O}_{2} \\
(\%)\end{array}$ & $\begin{array}{c}\text { Largura da. } \\
\text { sangria }(\mathbf{m m})\end{array}$ \\
\hline 11 & 12,6 & 39,5 & 99.95 & 0,270 \\
\hline 2 & 12,6 & 29,3 & 99,50 & 0,274 \\
\hline 12 & 12,6 & 288,9 & 99,95 & 0,272 \\
\hline 1 & 12,6 & 291,3 & 99,50 & 0,269 \\
\hline $9 P$ & 25,2 & 39,8 & 99,95 & 0,283 \\
\hline $6 \mathrm{P}$ & 25,2 & 40,1 & 99,50 & 0,281 \\
\hline $7 \mathrm{P}$ & 25,2 & 274,5 & 99.95 & 0,269 \\
\hline $1 \mathrm{P}$ & 25,2 & 289,1 & 99,50 & 0,266 \\
\hline $8 \mathrm{M}$ & 38,1 & 26,9 & 99.95 & 0,302 \\
\hline $12 \mathrm{M}$ & 38,1 & 26,5 & 99,50 & 0,309 \\
\hline $7 \mathrm{M}$ & 38,2 & 257,5 & 99.95 & 0,271 \\
\hline $5 \mathrm{M}$ & 38,1 & 242,8 & 99,50 & 0,271 \\
\hline $8 \mathrm{G}$ & 50,8 & 37,5 & 99.95 & 0,266 \\
\hline $14 \mathrm{G}$ & 51,1 & 29,8 & 99,50 & 0,268 \\
\hline $7 \mathrm{G}$ & 50,4 & 238,8 & 99.95 & 0,247 \\
\hline $1 \mathrm{G}$ & 51,0 & 237,3 & 99,50 & 0,265 \\
\hline
\end{tabular}

Como pode ser observada, a maior dimensão da largura da sangria é sempre para a chapa cortada a frio, como já discutido anteriormente, a chapa que apresenta a menor 
velocidade da reação e em conseqüência deste fato, a reação ocorre por mais tempo, removendo assim mais material. Em oposição a esta afirmação, as chapas cortadas a quente são sempre as que apresentam o menor valor para esta dimensão. Para evidenciar os comportamentos em função das condições experimentais foram calculados valores médios para mostrar o efeito em cada situação. A figura 37 mostra os valores obtidos para a largura da sangria.

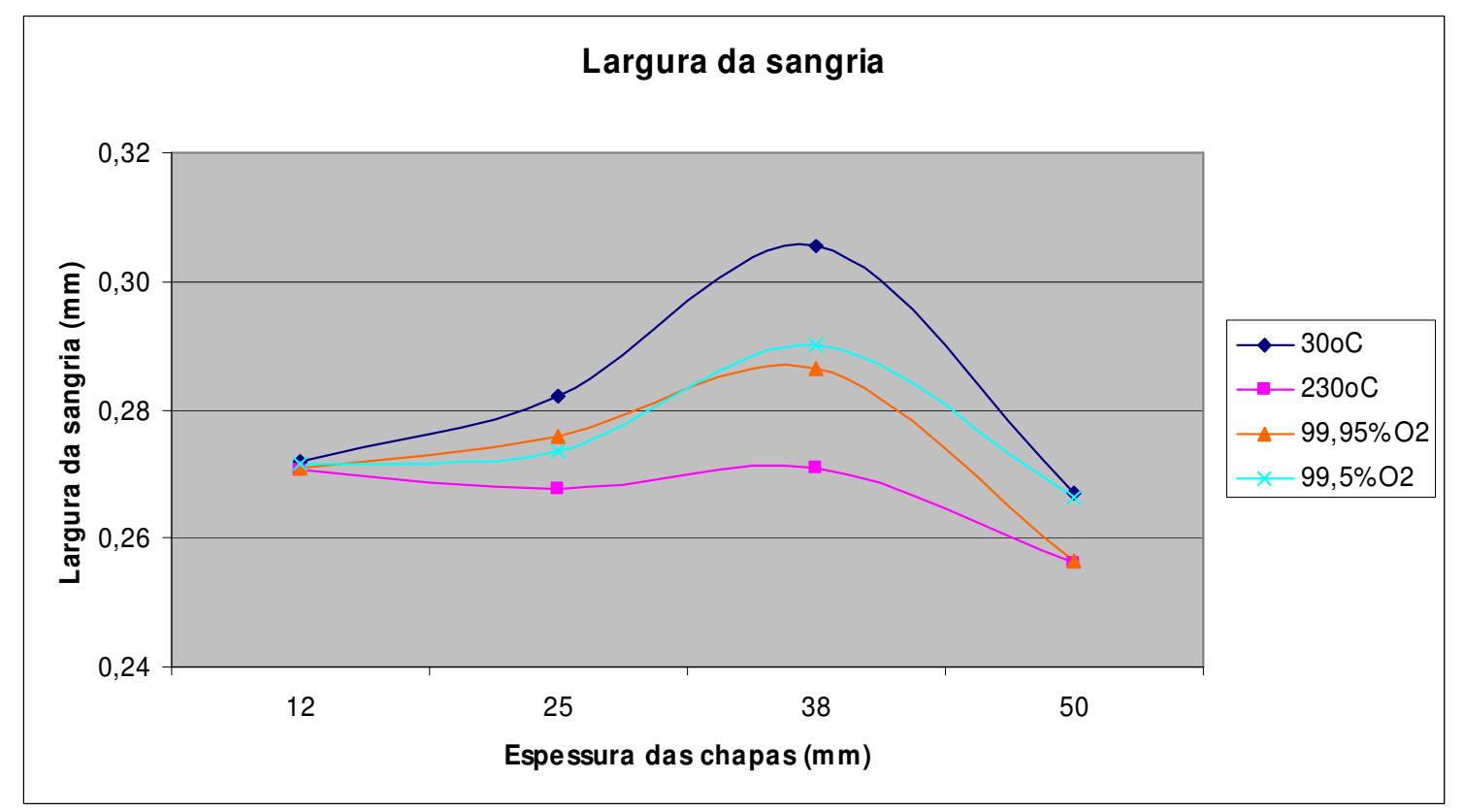

Figura 37 - Variação da largura da sangria em função da espessura da chapa e das condições experimentais utilizadas

A análise da figura 37 mostra que, exceto para a espessura de $12,7 \mathrm{~mm}$, o comportamento do gráfico evidencia que as temperaturas são determinantes na largura da sangria. Por outro lado, quando se analisa o efeito da concentração do $\mathrm{O}_{2}$ fica evidente que ocorre uma inversão no comportamento, quando comparado com o efeito da temperatura, principalmente para a chapa de $50,8 \mathrm{~mm}$. A utilização de $\mathrm{O}_{2}$ de alta pureza produz nas chapas finas maior largura de sangria do que acontece quando empregado no corte de chapas grossas. Esta inversão deve-se ao fato de que, na medida em que a espessura aumenta , a geração de contaminantes começa a comprometer a concentração do $\mathrm{O}_{2}$, diminuindo assim sua concentração e, consequentemente, a quantidade de calor gerada na 
reação de oxidação do material. A figura sugere que este ponto de inversão encontra-se entre a faixa de espessuras que vai de 30 a $35 \mathrm{~mm}$. Na espessura de $50 \mathrm{~mm}$, fica evidente que os maiores valores de largura da sangria são mesmo conseguidos com condições que dificultam o aumento da velocidade da reação, nomeadamente o corte sem pré-aquecimento e a utilização de $\mathrm{O}_{2}$ com menor concentração. Na chapa de $12,7 \mathrm{~mm}$ a espessura da sangria não foi influenciada por nenhuma das condições experimentais.

\subsection{TRANSFERÊNCIA DE CALOR NO OXICORTE}

Um aspecto fundamental para a compreensão e entendimento do processo oxicorte é o correto equacionamento do fluxo de calor atuante durante a execução do corte. Para este trabalho foram empregadas duas abordagens sobre este assunto, uma para o cálculo da quantidade de calor produzida pela chama e pela reação de oxidação ${ }^{[2]}$ e outra para a aplicação da transferência de calor no oxicorte ${ }^{[85] .}$

O trabalho de GLIZMANENKO E YEVSEYEV ${ }^{[2]}$ é um estudo onde as dimensões da peça em questão são utilizadas criando assim uma solução específica. Este trabalho apresenta alguns valores como constantes, que nesta tese foram recalculados visando ajustar o modelo proposto. Já o trabalho de $\mathrm{GRONG}^{[85]}$ é o prosseguimento dos estudos de ROSENTHAL ${ }^{[1]}$ onde é estudada uma solução geral da equação que governa o fluxo de calor durante a soldagem, que é transformada para soluções adimensionais, cujo objetivo é a utilização para diferentes condições, como diferentes espessuras, materiais e temperatura de pré-aquecimento.

\subsubsection{DETERMINAÇÃO DA TEMPERATURA DE CORTE.}

Uma informação importante para o estudo da transferência de calor no processo oxicorte é a determinação da temperatura onde ocorre o corte. Existem diversas propostas na literatura ${ }^{[1,2,18,45,48]}$, com valores variando deste 1350 até $1600^{\circ} \mathrm{C}$, que é uma temperatura acima do ponto de fusão de aços carbono.

Para determinar a temperatura de corte foi utilizado o diagrama de fases $\mathrm{Fe}-\mathrm{O}$ e a 
composição dos óxidos $\mathrm{FeO}$ e $\mathrm{Fe}_{3} \mathrm{O}_{4}$ produzidos. Foi aplicada a regra da alavanca, admitindo-se os valores das composições dos óxidos e como incógnita a quantidade de oxigênio no sistema Fe-O. Para este cálculo foi suposto que existe equilíbrio termodinâmico e que os elementos de liga presentes no aço não modifiquem as composições e temperaturas do diagrama Fe-O. O valor médio obtido para todos os 18 experimentos foi de $(26,2 \pm 0,2) \%$ de oxigênio em peso. Este valor foi colocado no diagrama obtendo-se o valor da temperatura de fusão para esta composição de $1424^{\circ} \mathrm{C}$. Foi proposto um superaquecimento de $20^{\circ} \mathrm{C}$ e a temperatura de corte para este trabalho foi assumida como sendo $1444^{\circ} \mathrm{C}$. Este valor está próximo do valor citado na referência ${ }^{[48]}$ que é de $1400^{\circ} \mathrm{C}$. A figura 38 mostra o resultado obtido no diagrama Fe-O.

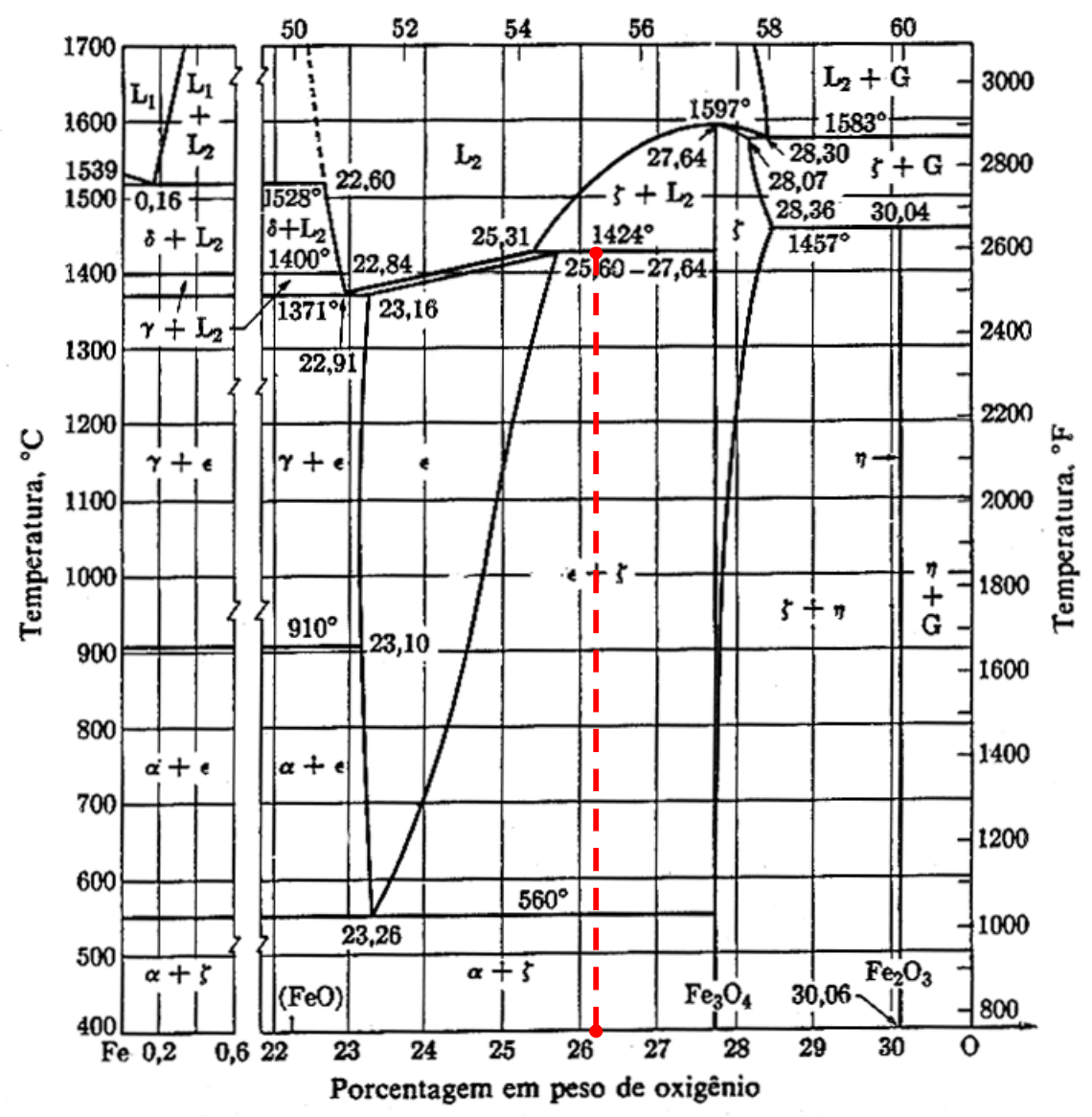

L.S. Darken e R.W. Gurrey, "Iron-Oxygen", Metals Handbook,

American Society for Metals, 1948, p. 1212

Figura 38 - Determinação da temperatura de corte com base na composição química dos óxidos da escória 
Conforme dados publicados na literatura, a temperatura liquidus do aço ASTM A36 é ao redor de $1538{ }^{\circ} \mathrm{C}$. A temperatura de fusão da magnetita é de $1597^{\circ} \mathrm{C}$. Com base nestes dados o aço provavelmente não fundirá no processo de corte, a menos que a chama de préaquecimento produza a fusão. Da mesma maneira, com base no diagrama de fases, na temperatura de corte a magnetita não está líquida. Isto significa que o liquido em contato com o aço durante o corte é uma suspensão composta de wüstita líquida, magnetita sólida e ferro, que pode estar líquido ou sólido.

\subsubsection{TRANSFÊRENCIA DE CALOR CONFORME O MODELO DE GRONG ${ }^{[85]}$}

O modelo proposto por GRONG ${ }^{[85]}$ possibilita a obtenção da temperatura em um dado ponto de interesse. Contrariamente a soldagem, onde se podem analisar os pontos em uma zona fundida, no oxicorte o óxido funde e é expulso do local, formando a sangria. Desta forma, o ponto de interesse passa a ser a zona afetada pelo calor (ZAC), que pode ter sua distância da zona fundida medida nas peças cortadas. A dimensão da ZAC das peças estudadas é apresentada no item 5.4.2.1 e a mudança para variáveis adimensionais da equação da transferência de calor no item 5.4.2.2.

\subsubsection{DIMENSÕES DA ZAC NAS PEÇAS ESTUDADAS}

As dimensões da ZAC foram obtidas através de medições feitas no estereoscópio conforme os exemplos apresentados nas figuras 39 e 40. Analisando-se as figuras nota-se que a extensão da ZAC não é uniforme, sendo maior na lateral do corte do que na frente de corte. Neste item foram medidas as extensões da ZAC na frente do corte, pois a parte posterior sofre um reaquecimento com a passagem da parte de trás da chama de préaquecimento, após a passagem do bico do maçarico.

Foi adotado o valor médio dos pontos localizados na frente de corte, pois o comportamento do tamanho da ZAC modifica-se com a passagem da parte de trás da chama do maçarico após a operação de corte, produzindo assim um novo aquecimento que explica porque a parte mais distante da frente de corte apresenta maiores dimensões de ZAC. 


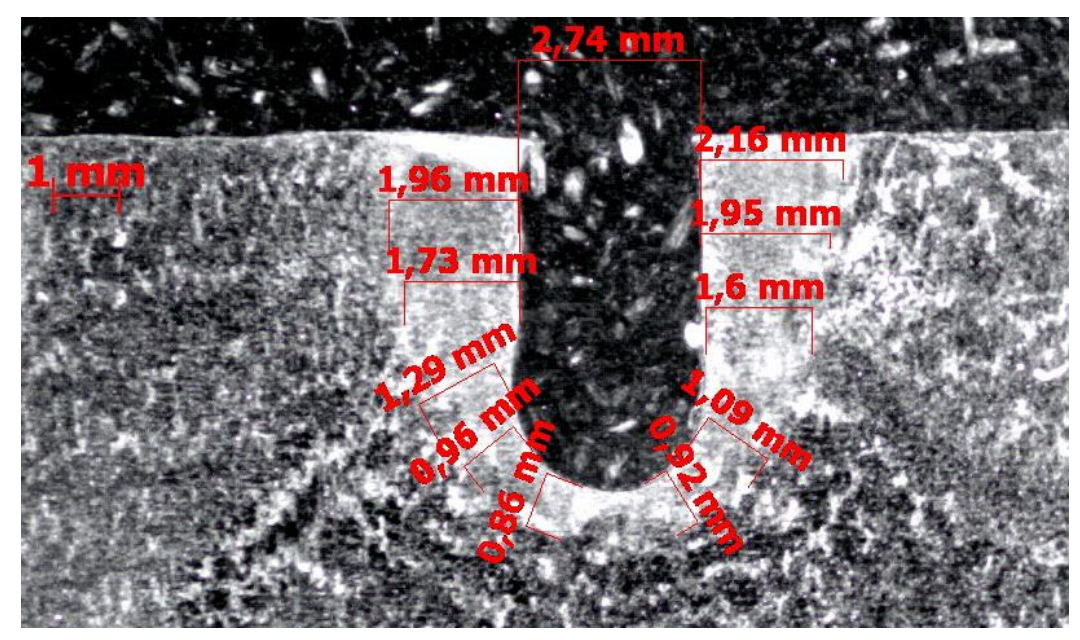

Figura 39 - Medição da ZAC nas peças cortadas (experimento 11)

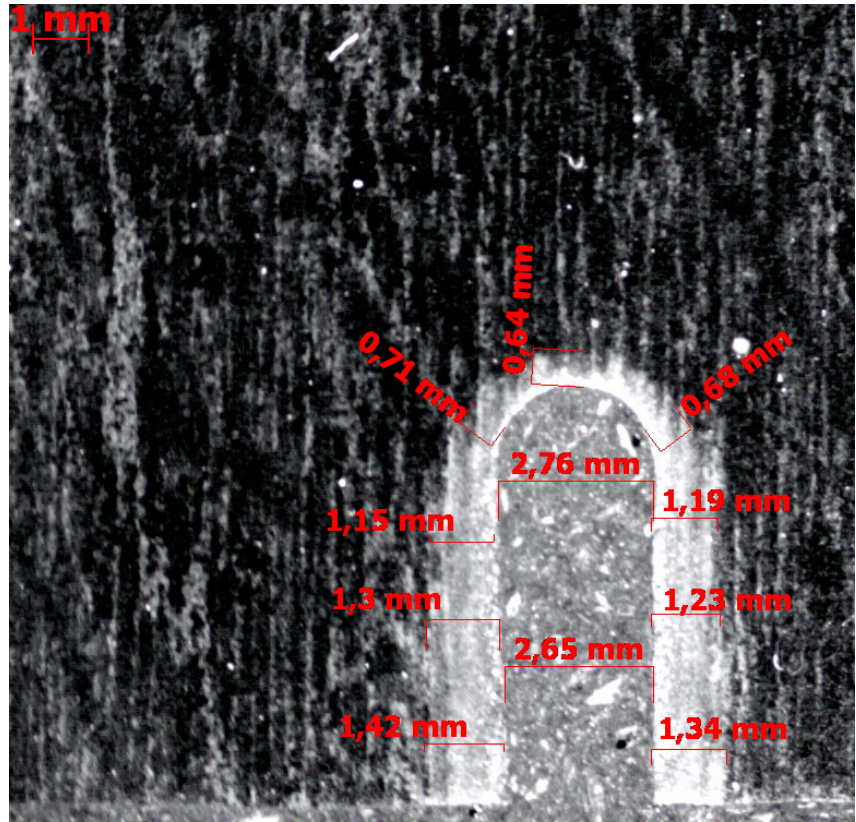

Figura 40 - Medição da ZAC nas peças cortadas (experimento 12) 
Os valores dos corpos-de-prova de interesse estão apresentados na tabela 21.

TABELA 21 - DIMENSÕES DA ZAC EM ALGUMAS PEÇAS CORTADAS

\begin{tabular}{|c|c|c|c|c|c|c|c|c|}
\hline Chapa & $\begin{array}{c}\mathrm{e} \\
(\mathrm{mm})\end{array}$ & $\begin{array}{c}\text { T. } \\
\text { pré } \\
\left({ }^{\circ} \mathrm{C}\right)\end{array}$ & $\begin{array}{c}\text { Conc } \\
\mathrm{O}_{2} \%\end{array}$ & $\begin{array}{c}\text { Valor } \\
1\end{array}$ & $\begin{array}{c}\text { Valor } \\
2\end{array}$ & $\begin{array}{c}\text { Valor } \\
3\end{array}$ & $\begin{array}{c}\text { Valor } \\
4\end{array}$ & média \\
\hline 11 & 12,7 & 40 & 99,95 & & 0,71 & 0,64 & 0,68 & 0,677 \\
\hline 12 & 12,7 & 289 & 99,95 & 1,09 & 0,96 & 0,86 & 0,92 & 0,958 \\
\hline $7 \mathrm{M}$ superior & 38,1 & 258 & 99,95 & & 0,76 & 0,77 & 0,80 & 0,777 \\
\hline $7 \mathrm{M}$ inferior & 38,1 & 258 & 99,95 & & 0,77 & 0,67 & & 0,720 \\
\hline
\end{tabular}

Analisando-se os resultados da tabela 21 percebe-se que ocorre um aumento na extensão da ZAC quando a temperatura inicial da chapa é aumentada. Como todas as outras variáveis foram mantidas constantes, este é um indício de que houve um aumento na quantidade de calor gerada no processo ligada a variação da velocidade de resfriamento conseqüência do pré aquecimento.

\subsubsection{ADIMENSIONALIZAÇÃO DA EQUAÇÃO DE TRANSFERÊNCIA DE} CALOR

A equação (37), apresentada no item 2.3 .5 (e reapresentada abaixo), pode ser apresentada com valores adimensionais de temperatura, calor, tempo e posição.

$$
\frac{T-T_{0}}{T_{c}-T_{0}}=\frac{Q}{2 \pi k d} e^{\left(-\frac{v x}{2 a}\right)} K_{0}\left(\frac{v r}{2 a}\right)
$$

Para facilidade de compreensão serão mostrados os valores adimensionais da equação (37).

a) adimensionalização da temperatura do corte. 


$$
\theta=\frac{T-T_{0}}{T c-T_{0}}
$$

Onde:

$\mathrm{T}=$ Temperatura de interesse

$\mathrm{T}_{0}=$ Temperatura do inicio do corte (temperatura do pré aquecimento)

$\mathrm{Tc}=$ Temperatura de corte: $1444^{\circ} \mathrm{C}$ (temperatura que ocorre a reação de oxidação)

b) adimensionalização do insumo de energia.

A adimensionalização do insumo de energia é feita através do parâmetro $\mathrm{n}_{4}$, cuja equação está mostrada a seguir:

$$
n_{4}=\frac{\eta Q v}{4 \pi a^{2} \Delta H}
$$

Onde:

$\eta=$ eficiência térmica do processo

$\mathrm{Q}=$ quantidade de calor

$\mathrm{v}=$ velocidade de corte

$\mathrm{a}=$ difusividade térmica

$\Delta \mathrm{H}=$ capacidade térmica por unidade de volume.

c) adimensionalização da espessura.

$$
\delta=\frac{v e}{2 a}
$$

Onde:

$\mathrm{v}=$ velocidade de corte

$\mathrm{e}=$ espessura da chapa

$\mathrm{a}=$ difusividade térmica do material 
d) adimensionalização das coordenadas na chapa.

Para se ter uma idéia das coordenadas utilizadas no modelo é mostrada a figura 41 , retirada da referência ${ }^{[85]}$.

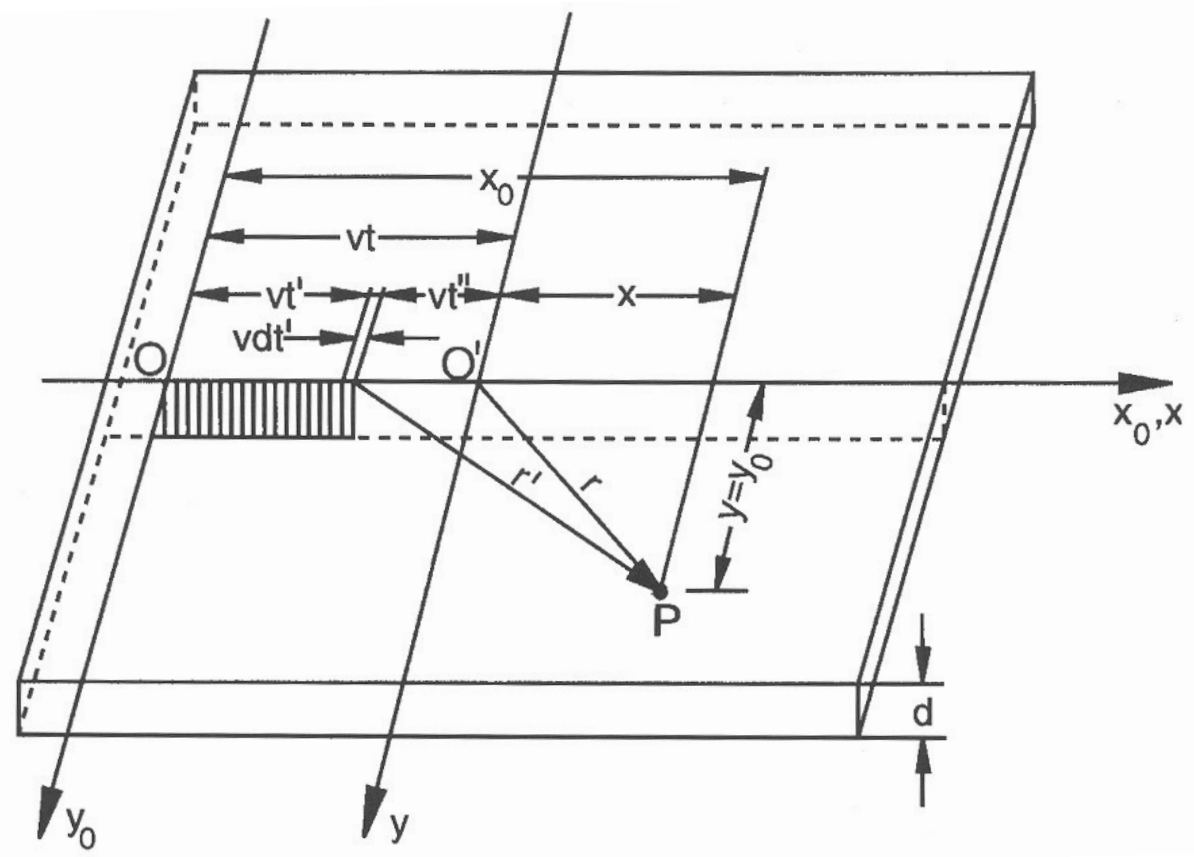

Figura 41 - Coordenadas empregadas no modelo de transferência de calor.

A coordenada ' $x$ ' é adimensionalizada pela equação:

$$
\xi=\frac{x v}{2 a}
$$

Onde:

$\mathrm{x}=$ definido na figura 39 .

$\mathrm{a}=$ difusividade térmica do material

$\mathrm{v}=$ velocidade de corte (constante em todos os experimentos)

A coordenada ' $y$ ' é adimensionalizada pela equação:

$$
\psi=\frac{y v}{2 a}
$$


Onde:

$\mathrm{y}=$ definido na figura 38.

$\mathrm{a}=$ difusividade térmica do material

$\mathrm{v}=$ velocidade de corte (constante em todos os experimentos)

A coordenada do vetor posição 'r' é adimensionalizada pela equação:

$$
\sigma_{5}=\frac{r v}{2 a}
$$

Onde:

$\mathrm{r}=$ definido na figura $38=\left(\mathrm{x}^{2}+\mathrm{y}^{2}\right)^{1 / 2}$

$\mathrm{a}=$ difusividade térmica do material

$\mathrm{v}=$ velocidade de corte (constante em todos os experimentos)

e) adimensionalização do tempo:

$$
\tau=\frac{v^{2} t}{2 a}
$$

Onde:

$\mathrm{t}=$ tempo.

\subsubsection{CÁLCULO DA EXTENSÃO DA ZAC SEGUNDO GRONG ${ }^{[85]}$}

f) cálculo da extensão da ZAC

O cálculo da extensão da ZAC pode ser obtido segundo $\mathrm{GRONG}^{[85]}$ pela figura 42, com base no valor de $\psi$. Para tanto o $\theta$ deve ser calculado para a temperatura eutetóide do aço, que foi admitida como sendo $723^{\circ} \mathrm{C}$. Da mesma maneira, os valores medidos da extensão da ZAC, apresentados na tabela 21, deverão ser adimensionalizados segundo a equação 44. Entrando-se com o valor de $\psi$ no gráfico tem-se o valor de $\mathrm{n}_{4} / \theta \delta$. Com os valores de $\theta$ e $\delta$, determina-se $n_{4}$. 


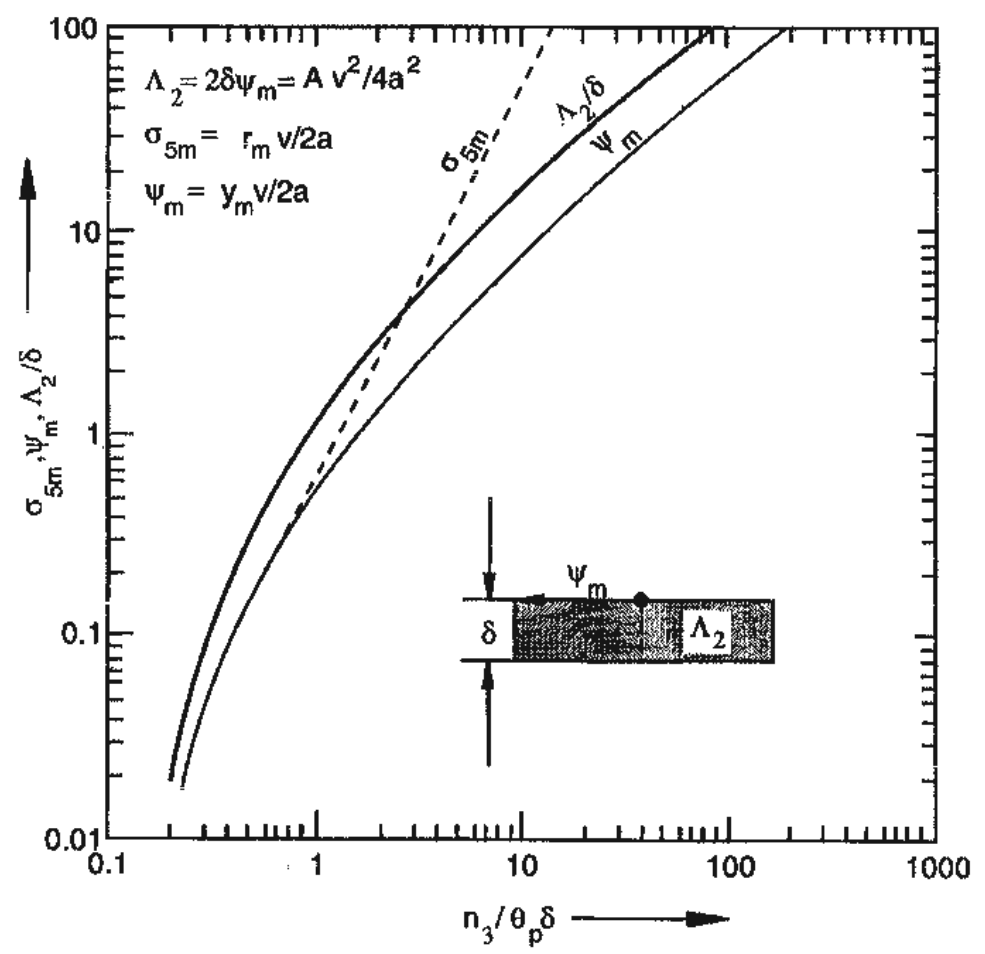

Figura 42 - Gráfico para a obtenção de dados para cálculo da temperatura da ZAC ${ }^{[85]}$

Visando a simplificação da obtenção deste dado, é proposto o modelo apresentado na equação 47 que para $\psi$ no intervalo 0,8 a 9 tem uma precisão de $95 \%$.

$$
\frac{n_{4}}{\theta_{Z A C} \delta}=10^{-4} \psi^{3}+1,52 \times 10^{-2} \psi^{2}+1,0493 x \psi+0,3376
$$

\subsubsection{CÁlCULO DA ENERGIA NO PROCESSO CONFORME MODELO DE GRONG $^{[85]}$}

Assim, com base na metodologia de $\mathrm{GRONG}^{[85]}$ apresentada foi calculada a transferência de calor em algumas peças cortadas. Os valores do $\Delta \mathrm{H}$ adotados, conforme sugerido pelo autor, são de $7,3 \mathrm{~J} / \mathrm{mm}^{3}$ para chapa fria e $6,3 \mathrm{~J} / \mathrm{mm}^{3}$ para chapa com pré-aquecimento, e o valor do calor total envolvido é calculado conforme a equação 37. Os resultados destes cálculos são apresentados na tabela 22. 
TABELA 22 - CÁLCULO DA ENERGIA GERADA NO CORTE CONFORME MODELO DE GRONG ${ }^{[85]}$

\begin{tabular}{|c|c|c|c|c|c|c|c|c|c|c|c|c|}
\hline Chapa & $\begin{array}{c}\mathrm{e} \\
(\mathrm{mm})\end{array}$ & $\begin{array}{c}\text { T. pré } \\
\left({ }^{\circ} \mathrm{C}\right)\end{array}$ & $\begin{array}{c}\text { Conc } \\
\mathrm{O}_{2(\%)}\end{array}$ & $\psi$ & $\mathrm{n}_{4} / \theta_{\text {zac }}$ & $\begin{array}{c}\mathrm{T} \\
\text { int } \\
\left({ }^{\circ} \mathrm{C}\right)\end{array}$ & $\begin{array}{c}\mathrm{T} \\
\text { corte } \\
\left({ }^{\circ} \mathrm{C}\right)\end{array}$ & $\boldsymbol{\theta}$ & $\delta$ & $\mathrm{n}_{4}$ & $\Delta \mathrm{H}$ & $\begin{array}{c}\mathrm{Q} \\
(\mathrm{J} / \mathrm{mm})\end{array}$ \\
\hline 12 & 12,7 & 289 & 99,95 & 0,50 & 0,973 & 723 & 1444 & 0,411 & 5,77 & 2,31 & 6,3 & $\mathbf{1 6 6 0}$ \\
\hline 11 & 12,7 & 40 & 99,95 & 0,39 & 0,842 & 723 & 1444 & 0,338 & 5,77 & 1,64 & 7,3 & 1325 \\
\hline $7 \mathrm{~m}$ superior & 38,1 & 258 & 99,95 & 0,37 & 0,816 & 723 & 1444 & 0,400 & 17,33 & 5,65 & 6,3 & $\mathbf{4 2 5 2}$ \\
\hline $7 \mathrm{~m}$ inferior & 38,1 & 258 & 99,95 & 0,37 & 0,822 & 723 & 1444 & 0,400 & 17,33 & 5,70 & 6,3 & $\mathbf{4 0 9 4}$ \\
\hline
\end{tabular}

\subsubsection{CÁlCULO DA QUANTIDADE DE CALOR GERADA NO PROCESSO CONFORME GLIZMANENKO E YEVSEYEV ${ }^{[2]}$}

$\mathrm{Na}$ metodologia destes autores, o cálculo utiliza os valores de uma composição química média de óxidos, dados relativos à chama de pré-aquecimento e largura da sangria. Os cálculos aqui apresentados utilizaram os valores das análises químicas reais, realizadas por difração de raios $\mathrm{X}$ nas peças pesquisadas.

Os cálculos com esta metodologia foram feitos para todas as peças cortadas e apresentam algumas unidades diferentes do trabalho de $\mathrm{GRONG}^{[85]}$ para preservar a metodologia dos autores, porém ambos apresentam o resultado final em $\mathrm{J} / \mathrm{mm}$, que é a unidade adotada por Grong.

\subsubsection{VALORES UTILIZADOS PARA O CÁLCULO}

A metodologia proposta por estes autores utiliza para o cálculo os seguintes dados:

a) Velocidade de corte: velocidade de $7,28 \mathrm{~mm} / \mathrm{s}$ utilizados no modelo de cálculo anteriormente apresentado.

b) Vazão do acetileno: constante em todas as chapas cortadas, $410 \mathrm{l} / \mathrm{h}$.

c) Temperatura da reação: $1444^{\circ} \mathrm{C}$, igual à utilizada no cálculo anterior.

d) Calor de fusão dos óxidos: $103 \mathrm{cal} / \mathrm{g}$.

e) Capacidade térmica específica do $\mathrm{FeO}: 0,16 \mathrm{cal} /{ }^{\circ} \mathrm{C}$.

f) Capacidade térmica específica do $\mathrm{Fe}_{3} \mathrm{O}_{4}: 0,24 \mathrm{cal} /{ }^{\circ} \mathrm{C}$. 
Alguns valores foram encontrados com maior exatidão que os disponíveis na metodologia dos autores. Para calcular as quantidades calor na chapa antes do corte, nos óxidos formados, na oxidação do ferro do aço e na combustão do acetileno foram utilizados dados publicados ${ }^{[140,141]}$ que são os apresentados na tabela 23.

TABELA 23 - DADOS UTILIZADOS PARA CÁLCULO DAS QUANTIDADES DE CALOR ${ }^{[140,141]}$

\begin{tabular}{|c|c|c|c|c|c|c|}
\hline & \multicolumn{4}{|c|}{$\mathrm{C}_{\mathrm{p}}(\mathrm{cal} / \mathrm{K} . \mathrm{mol}) *$} & \multirow{2}{*}{$\begin{array}{l}\text { Calor latente } \\
\text { de } \\
\text { transf.(J/mol) }\end{array}$} \\
\hline & & $\mathrm{a}$ & $\mathrm{b}$ & $\mathrm{c}$ & $\begin{array}{c}\text { Intervalo de } \\
\text { Temperatura (K) }\end{array}$ & \\
\hline $\mathrm{Fe}(\alpha)$ & \multirow{5}{*}{ Sólido } & 8,873 & 1,474 & - & Até 1187 & - \\
\hline $\mathrm{Fe}(\gamma)$ & & 5,85 & 2,02 & - & $1187-1664$ & - \\
\hline $\mathrm{Fe}(\delta)$ & & 8,873 & 1,474 & - & 1664-1834 & - \\
\hline $\mathrm{Fe}(\alpha) \rightarrow \mathrm{Fe}(\gamma)$ & & - & - & - & 1187 & 5.110 \\
\hline $\mathrm{Fe}(\gamma) \rightarrow \mathrm{Fe}(\delta)$ & & - & - & - & 1664 & 563 \\
\hline $\mathrm{Fe}_{0,947} \mathrm{O}$ & Sólido & 11,66 & 2,00 & $-0,67$ & $843-1651$ & - \\
\hline $\mathrm{Fe}_{0,947} \mathrm{O}_{(\mathrm{S})} \rightarrow \mathrm{Fe}_{0,947} \mathrm{O}_{(\mathrm{L})}$ & - & - & - & - & 1651 & 31.000 \\
\hline $\mathrm{Fe}_{0,947} \mathrm{O}$ & Líquido & 16,30 & - & - & $1651-1800$ & - \\
\hline $\mathrm{Fe}_{3} \mathrm{O}_{4}(\alpha)$ & Sólido & 21,88 & 48,2 & - & $298-900$ & - \\
\hline $\mathrm{Fe}_{3} \mathrm{O}_{4}(\beta)$ & Sólido & 48,00 & - & - & $900-1870$ & - \\
\hline $\mathrm{Fe}_{3} \mathrm{O}_{4}(\beta) \rightarrow \mathrm{Fe}_{3} \mathrm{O}_{4(\mathrm{~L})}$ & $-T^{-}$ & - & - & - & 1870 & 138.200 \\
\hline
\end{tabular}

Com base nos dados da tabela 23 e considerando a temperatura de corte de $1444^{\circ} \mathrm{C}$ $(1717 \mathrm{~K})$, foram calculadas as quantidades de calor para a chapa nas temperaturas ambiente (referência $\left.30^{\circ} \mathrm{C}\right)$ e para chapas pré-aquecidas $\left(230^{\circ} \mathrm{C}\right)$ até a temperatura de corte. Os valores obtidos estão apresentados na tabela 24. Os valores foram transformados para cal/g para manter-se uniforme às unidades da metodologia de cálculo proposta por estes autores.

TABELA 24 - QUANTIDADE DE CALOR ENTRE AS TEMPERATURAS INICIAIS DAS CHAPAS E A TEMPERATURA DE CORTE

\begin{tabular}{|l|c|c|c|}
\hline & $\begin{array}{c}\text { Temperatura nominal da } \\
\text { chapa }\left({ }^{\circ} \mathrm{C}\right)\end{array}$ & $\begin{array}{c}\text { Quantidade } \\
\text { de calor }(\mathrm{J} / \mathrm{g})\end{array}$ & $\begin{array}{c}\text { Quantidade de } \\
\text { calor }(\mathrm{cal} / \mathrm{g})\end{array}$ \\
\hline aço & 30 & 1175 & 281 \\
\hline $\mathrm{Fe}_{0,947} \mathrm{O}$ & 230 & 1062 & 254 \\
\cline { 2 - 4 } & 30 & 2128 & 509 \\
\hline $\mathrm{Fe}_{3} \mathrm{O}_{4}$ & 230 & 2128 & 509 \\
\cline { 2 - 4 } & 30 & 3298 & 789 \\
\hline
\end{tabular}


Com os dados da tabela 24, da composição da escória do corte, da área da sangria e dos parâmetros de corte (vazão do acetileno da chama de pré-aquecimento e velocidade de corte, espessura da chapa) foi então calculada a quantidade de energia gerada no processo de corte.

\subsubsection{CÁlCUlO DA ENERGIA NO PROCESSO CONFORME MODELO DE GLIZMANENKO E YEVSEYEV ${ }^{[2]}$}

Para calcular o insumo de energia durante o oxicorte devem ser levadas em consideração a somatória da energia produzida pela chama de pré-aquecimento, pela reação de oxidação e pela reação de oxidação de outros elementos químicos presentes no aço além do ferro.

a) cálculo do calor produzido pela chama de pré-aquecimento.

O calor produzido pela chama de pré-aquecimento é dado pela equação:

$$
Q_{\text {chama }}=\frac{12600 V_{\text {acet }}}{v}
$$

onde:

$12600=$ calor gerado na combustão do acetileno em cal/s

$\mathrm{V}$ acet $=$ vazão do acetileno $\mathrm{em} \mathrm{l} / \mathrm{h}$.

$\mathrm{v}=$ velocidade de corte $\mathrm{em} \mathrm{m} / \mathrm{s}$

b) cálculo do calor produzido pela oxidação do ferro.

O calor produzido pela oxidação do ferro é dado pela equação:

$$
Q_{\text {oxidas } \tilde{a} o}=\rho_{F e} b G\left(\% \mathrm{FeO} \cdot \Delta H_{\mathrm{FeO}}^{0}+\% \mathrm{Fe}_{3} \mathrm{O}_{4} \cdot \Delta H_{\mathrm{Fe}_{3} \mathrm{O}_{4}}^{0}\right)
$$


onde:

$\rho_{\mathrm{Fe}}=$ densidade do ferro $=7,86 \mathrm{~g} / \mathrm{cm}^{3}$.

$\mathrm{b}=$ largura da sangria $(\mathrm{em} \mathrm{cm})$

$\mathrm{G}=$ massa de ferro da sangria por metro de corte

$\% \mathrm{FeO}=$ porcentagem de wüstita na escória $(\mathrm{cal} / \mathrm{g})$

$\Delta \mathrm{H}_{\mathrm{FeO}}^{0}=$ entalpia de formação de $\mathrm{FeO}$

$\% \mathrm{Fe}_{3} \mathrm{O}_{4}=$ porcentagem de magnetita na escória

$\Delta \mathrm{H}_{\mathrm{Fe}_{3} \mathrm{O}_{4}}^{0}=$ entalpia de formação de $\mathrm{Fe}_{3} \mathrm{O}_{4}(\mathrm{cal} / \mathrm{g})$

c) cálculo do calor de oxidação dos demais elementos químicos presentes no aço.

O valor da combustão dos elementos químicos presentes no aço, principalmente $\mathrm{Mn}$ e $\mathrm{Si}$, foram admitidos com sendo 3,5\% do calor produzido pela equação (45).

Com os dados obtidos foi feito o calculo da energia gerada no processo de oxicorte para todos os experimentos. Os resultados estão apresentados na tabela 25.

TABELA 25 - CÁLCULO DA ENERGIA GERADA NO CORTE CONFORME METODOLOGIA DE GLIZMANENKO E YEVSEYEV ${ }^{[2]}$

\begin{tabular}{|c|c|c|c|c|c|c|c|c|c|c|c|c|c|c|}
\hline \multirow{3}{*}{$n^{0}$} & \multirow{3}{*}{$\begin{array}{l}\mathrm{O}_{2} \\
(\%)\end{array}$} & \multirow{3}{*}{$\begin{array}{c}\mathrm{e} \\
(\mathrm{mm})\end{array}$} & \multirow{3}{*}{$\begin{array}{l}\text { Larg. } \\
\text { sang. } \\
\text { (mm) }\end{array}$} & \multicolumn{3}{|c|}{ C.Q. escória (\%) } & \multirow{3}{*}{$\begin{array}{l}\text { temp } \\
\text { pré } \\
\text { aq } \\
\left({ }^{\circ} \mathrm{C}\right)\end{array}$} & \multicolumn{3}{|c|}{$\begin{array}{c}\text { Qte calor na T. } \\
\text { corte (cal/g) }\end{array}$} & \multicolumn{3}{|c|}{ Calor em kcal/m } & \multirow{3}{*}{$\begin{array}{c}Q \\
(\mathrm{~J} / \mathrm{mm})^{*}\end{array}$} \\
\hline & & & & \multirow{2}{*}{$\mathrm{FeO}$} & \multirow{2}{*}{$\mathrm{Fe}_{3} \mathrm{O}_{4}$} & \multirow{2}{*}{$\mathrm{Fe}$} & & \multirow{2}{*}{$\mathrm{FeO}$} & \multirow{2}{*}{$\mathrm{Fe}_{3} \mathrm{O}_{4}$} & \multirow{2}{*}{$\mathrm{Fe}$} & \multirow{2}{*}{ chama } & \multicolumn{2}{|c|}{ Combustão } & \\
\hline & & & & & & & & & & & & $\mathrm{Fe}$ & impurezas & \\
\hline 11 & 99.95 & 12,6 & 0,270 & 0,60 & 0,14 & 0,25 & 39,5 & 509 & 781 & 281 & 211,19 & 241,25 & 8,44 & 1926,55 \\
\hline 2 & 99,5 & 12,6 & 0,274 & 0,52 & 0,37 & 0,09 & 29,3 & 509 & 781 & 281 & 211,19 & 319,48 & 11,18 & 2264,97 \\
\hline 12 & 100 & 12,6 & 0,272 & 0,56 & 0,12 & 0,30 & 289 & 509 & 823 & 239 & 211,19 & 223,96 & 7,83 & 1851,71 \\
\hline 1 & 99,5 & 12,6 & 0,269 & 0,56 & 0,35 & 0,07 & 291 & 509 & 789 & 254 & 211,19 & 320,90 & 11,23 & 2271,13 \\
\hline $9 \mathrm{P}$ & 100 & 25,2 & 0,283 & 0,62 & 0,12 & 0,23 & 39,8 & 509 & 781 & 281 & 211,19 & 511,38 & 17,89 & 3095,19 \\
\hline $6 \mathrm{P}$ & 99,5 & 25,2 & 0,281 & 0,55 & 0,28 & 0,15 & 40,1 & 509 & 781 & 281 & 211,19 & 597,56 & 20,91 & 3468,06 \\
\hline $7 \mathrm{P}$ & 99.95 & 25,2 & 0,269 & 0,53 & 0,26 & 0,18 & 275 & 509 & 789 & 254 & 211,19 & 541,70 & 18,95 & 3226,37 \\
\hline $1 \mathrm{P}$ & 99,5 & 25,2 & 0,266 & 0,51 & 0,38 & 0,10 & 289 & 509 & 789 & 254 & 211,19 & 621,75 & 21,76 & 3572,70 \\
\hline $8 \mathrm{M}$ & 99.95 & 38,1 & 0,302 & 0,53 & 0,23 & 0,23 & 26,9 & 509 & 781 & 281 & 211,19 & 875,95 & 30,65 & 4672,42 \\
\hline $12 \mathrm{M}$ & 99,5 & 38,1 & 0,309 & 0,56 & 0,35 & 0,07 & 26,5 & 509 & 781 & 281 & 211,19 & 1107,37 & 38,75 & 5673,64 \\
\hline $7 \mathrm{M}$ & 99.95 & 38,2 & 0,271 & 0,66 & 0,17 & 0,16 & 258 & 509 & 789 & 254 & 211,19 & 839,21 & 29,37 & 4513,48 \\
\hline $5 \mathrm{M}$ & 99,5 & 38,1 & 0,271 & 0,52 & 0,30 & 0,16 & 243 & 509 & 789 & 254 & 211,19 & 873,98 & 30,58 & 4663,91 \\
\hline $8 G$ & 99.95 & 50,8 & 0,266 & 0,64 & 0,18 & 0,17 & 37,5 & 509 & 781 & 281 & 211,19 & 1088,33 & 38,09 & 5591,26 \\
\hline $14 \mathrm{G}$ & 99,5 & 51,1 & 0,268 & 0,61 & 0,22 & 0,16 & 29,8 & 509 & 781 & 281 & 211,19 & 1129,78 & 39,54 & 5770,59 \\
\hline $7 G$ & 99.95 & 50,4 & 0,247 & 0,48 & 0,28 & 0,21 & 239 & 509 & 789 & 254 & 211,19 & 982,43 & 34,38 & 5133,12 \\
\hline $1 \mathrm{G}$ & 99,5 & 51 & 0,265 & 0,59 & 0,30 & 0,09 & 237 & 509 & 789 & 254 & 211,19 & 1222,88 & 42,80 & 6173,37 \\
\hline
\end{tabular}

* Os valores indicados em negrito são referentes às peças que foram feitas com as duas metodologias. 
Com base nos valores calculados e apresentados na tabela 24 foram elaboradas as figuras 43 e 44 .

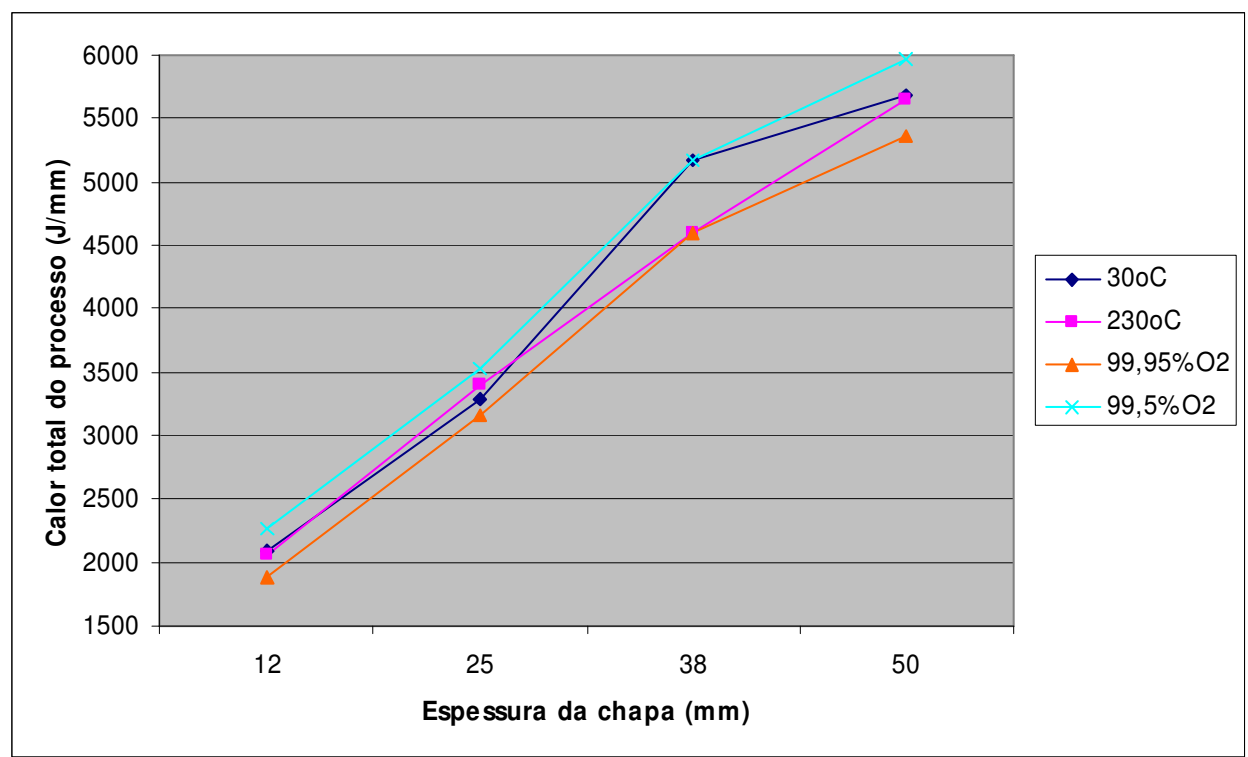

Figura 43 - Calor total gerado no processo de corte em função da espessura da chapa e das condições experimentais utilizadas

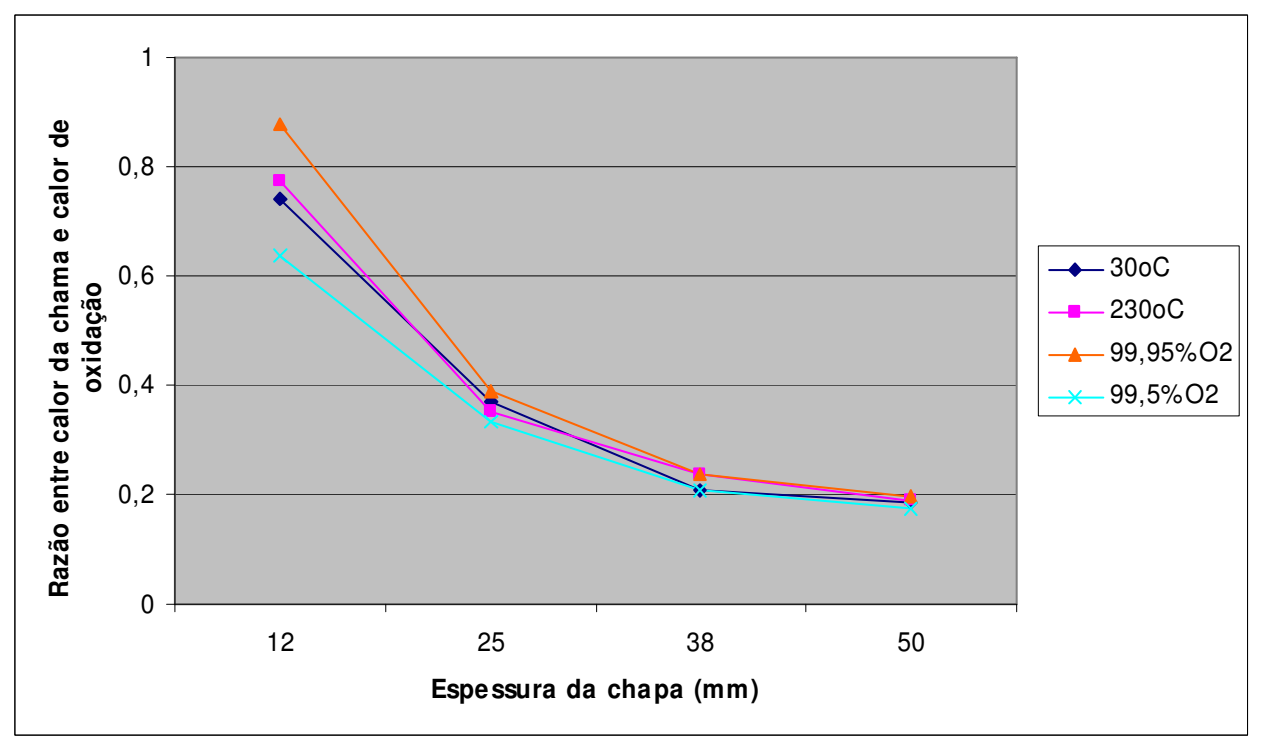

Figura 44 - Razão entre o calor gerado pela chama e o calor devido à oxidação do ferro e impurezas em função da espessura da chapa e das condições experimentais utilizadas 
A figura 43 mostra que a quantidade de calor total aumenta com o aumento da espessura. Analisando-se os efeitos das variáveis nota-se que a influência da concentração do oxigênio é mais significativa que a da temperatura da chapa. Este fato é devido à influência do calor de oxidação do ferro no processo de corte.

A figura 44 apresenta a razão entre o calor gerado pela chama e o calor gerado pela oxidação (ferro e outros elementos químicos). Observa-se que a curva é assintótica para 0,2 em todas as condições experimentais utilizadas. Conforme discutido anteriormente, a quantidade de calor predominante na chapa de $12,7 \mathrm{~mm}$ é da chama de pré-aquecimento, enquanto que as chapas de 38 e $50 \mathrm{~mm}$ quem prepondera é a reação de oxidação. Estes dados estão de acordo com a figura 19. Na figura 44 fica mais evidente a influência das condições experimentais

\subsubsection{COMPARAÇÃO ENTRE AS DIFERENTES METODOLOGIAS DE CÁLCULO DA ENERGIA GERADA NO PROCESSO OXICORTE}

Como pode ser visto, as duas metodologias de cálculo apresentam valores muito próximos, conforme é apresentado na tabela 26.

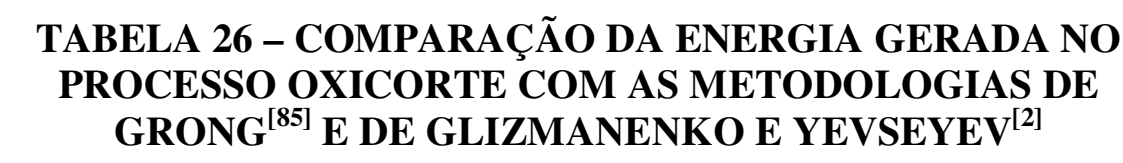

\begin{tabular}{|c|c|r|c|c|c|r|r|}
\hline \multirow{2}{*}{ Chapa } & \multirow{2}{*}{$\begin{array}{c}\mathrm{e} \\
(\mathrm{mm})\end{array}$} & \multirow{2}{*}{$\begin{array}{c}\text { T. pré } \\
\left({ }^{\circ} \mathrm{C}\right)\end{array}$} & $\begin{array}{c}\text { Conc } \\
\mathrm{O}_{2}(\%)\end{array}$ & \multicolumn{2}{|c|}{$\mathrm{Q}_{(\mathrm{J} / \mathrm{mm})}$} & \multicolumn{2}{c|}{ Diferença } \\
& & & & Grong & Glizmanenko & $(\mathrm{J} / \mathrm{mm})$ & $\%$ \\
\hline 11 & 12,7 & 40 & 99,95 & 1325 & 1926,55 & 601,8 & 31,23 \\
\hline 12 & 12,7 & 289 & 99,95 & 1660 & 1851,71 & 191,6 & 10,34 \\
\hline $7 m$ superior & 38,1 & 258 & 99,95 & 4252 & \multirow{2}{*}{4513,48} & 261,6 & 5,79 \\
\hline $7 m$ inferior & 38,1 & 258 & 99,95 & 4094 & & 419,7 & 9,30 \\
\hline
\end{tabular}

A metodologia de GRONG $^{[85]}$ apresenta valores ligeiramente menores, que são corrigidos pela eficiência térmica do processo. A diferença dos dois valores em porcentagem está relacionada com o valor da eficiência térmica do processo, que é definida pela 'quantidade de calor produzida pela quantidade de calor efetivamente introduzida na 
peça'. Os valores obtidos para a chapa de $12,7 \mathrm{~mm}$ na temperatura ambiente é de 0,688 (10,312). Já a chapa pré-aquecida a $230^{\circ} \mathrm{C}$ o valor é de 0,897 (1-0,103). Estes valores mostram que a eficiência térmica do processo é maior para a chapa pré-aquecida do que para a chapa na temperatura ambiente. No caso da chapa de $38 \mathrm{~mm}$, o valor médio da eficiência do processo é 0,925 .

\subsubsection{CICLO TÉRMICO TEÓRICO}

Com base nos valores calculados e medidos, apresentados anteriormente, foram feito os gráficos dos ciclos térmicos para a chapa de $12,7 \mathrm{~mm}$, com e sem pré-aquecimento, em distâncias da fonte de calor de 1,58 mm para a chapa sem pré-aquecimento e 1,66 mm para a chapa pré-aquecida. Para isto foi empregada a equação de Grong para regime 2D. Os resultados estão apresentados na figura 45 .

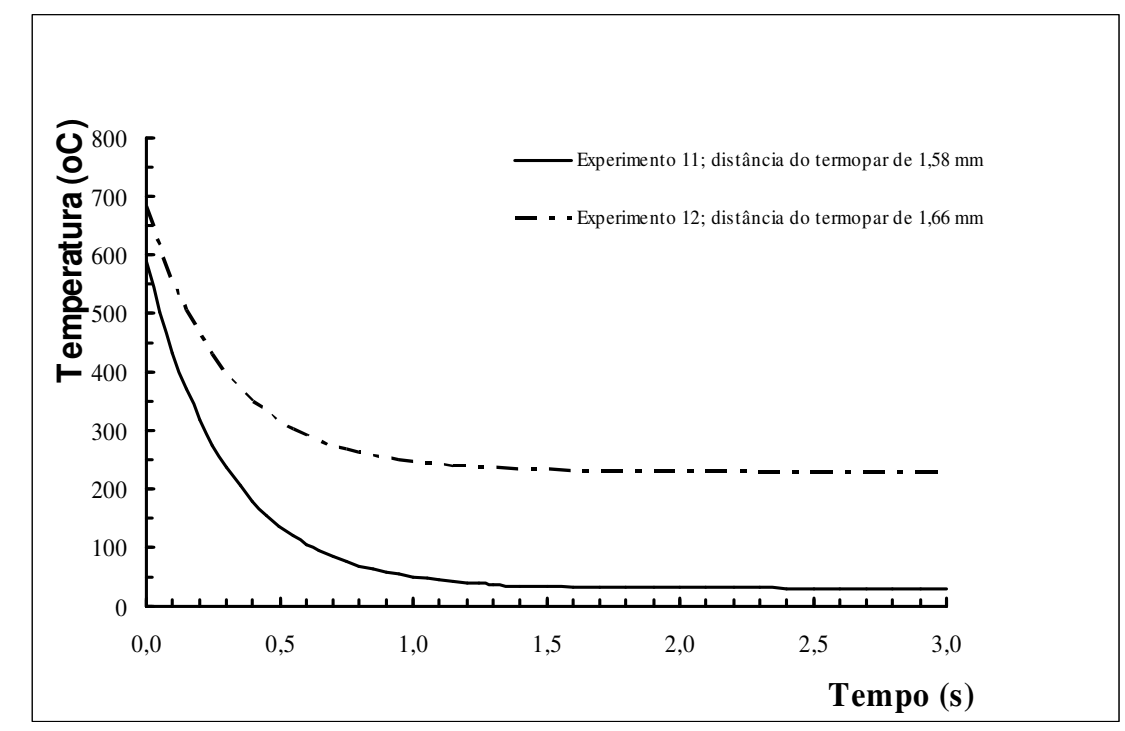

Figura 45 - Ciclo térmico teórico para a chapa de $12 \mathrm{~mm}$ sem pré-aquecimento (linha contínua) e com pré-aquecimento (linha tracejada)

Os resultados mostram que as temperaturas máximas estão segundo o esperado. A chapa sem pré-aquecimento apresenta um valor menor que a chapa pré-aquecida. Este resultado é devido a quantidade de calor inicial nas chapas serem diferentes e à quantidade de calor introduzida pela fonte ser muito próxima. 


\subsection{EMPREGO DE REDES NEURAIS ARTIFICIAIS EM MODELAMENTO}

Tendo sido apresentadas duas metodologias para o cálculo da energia gerada no processo oxicorte, é importante observar que ambas necessitam, para serem levadas a cabo, de informações que envolvem ou um processo complexo, demorado e dispendioso, como a difração de raios x ou uma operação destrutiva, como a análise macrográfica para medições da abertura da sangria, da espessura da zona fundida e do tamanho da ZAC produzidos.

Porém tanto os óxidos produzidos quanto as dimensões obtidas nas peças cortadas, são consequiência da interação de fenômenos que são resultantes da interação das variáveis de entrada adotadas no processo. Neste trabalho variou-se: temperatura de préaquecimento, concentração do $\mathrm{O}_{2}$ e espessura das peças escolhidas.

A utilização de Redes Neurais Artificiais tem comprovado sucesso na solução de problemas resultantes de complexas interações de variáveis, como estas que se apresentam, e sua utilização é aqui proposta para o modelamento tanto da composição química resultante como das dimensões das peças cortadas.

\subsubsection{ARQUITETURA DAS RNAS UTILIZADAS}

Como visto em 4.12.2, boa parte do sucesso da utilização de uma Rede Neural Artificial se deve aos cuidados tomados em sua implementação. Este trabalho utiliza a metodologia de implementação ${ }^{[133]}$ baseada em ciclos com uma extensa quantidade de redes que fazem os cálculos, comparam os valores com os dados reais que a rede foi treinada (auto validação) e em seguida comparam com dados com os quais a rede não foi treinada (validação cruzada), e por fim mede o desempenho da rede.

\subsubsection{PARÂMETROS FIXOS UTILIZADOS NAS RNAs}

O projeto construtivo das redes utilizadas considerou fixos os seguintes parâmetros: 
a) Tipo de rede: multilayer perceptron com algorítmo de aprendizado por retropropagação.

b) Funções de transferência: sigmoidal

c) Número de camadas escondidas: 2

d) Quantidade de épocas de treinamento: 10000

A escolha destes parâmetros foi baseada tanto na experiência quanto nas considerações de literatura ${ }^{[130,132]}$. As redes com algoritmo de aprendizado apresentam o retorno da informação, o "sinal de saída" o que faz com que a convergência seja mais rápida e mais precisa, embora possa estacionar em um mínimo local, que seria uma solução boa, mas não ótima. Este fato é o principal motivo de se utilizar diversas configurações de rede ${ }^{[133]}$.

Foram inicialmente rodadas redes com a utilização da função linear, mas a resposta para este tipo de problema proposto foi muito rápida e imprecisa. A razão disto pode estar relacionada à complexidade do fenômeno envolvido. Por esta razão, foi utilizada a função sigmoidal, que apresentou para este problema resultados muito mais precisos.

O número de camadas escondidas foi também escolhido baseado nas informações da literatura ${ }^{[132]}$ onde é citado que em casos de problemas de correlacionamento de variáveis, mais do que duas camadas de neurônios escondidos na verdade aumentam demasiadamente o tempo de processamento sem que propiciem grandes ganhos na precisão do resultado final.

\subsubsection{PARÂMETROS VARIÁVEIS UTILIZADOS NAS RNAs}

Os seguintes parâmetros foram utilizados com diferentes valores:

a) Constante de momentum: $0,2,0,5$ ou 0,8

b) Taxa de aprendizado: (1- constante de momentum)

c) Número de neurônios: 5, 10, 15, 20, 25 e 30 
A constante de momentum é o valor adicionado visando evitar que a rede estacione em mínimos locais, ou seja, em soluções não ideais. Um valor muito grande pode fazer com que a rede saia da resposta quando encontrar uma solução ótima e possa eventualmente não convergir mais para a solução por ficar continuamente buscando uma solução, enquanto um valor muito baixo pode fazer com que a rede fique extremamente instável. A taxa de aprendizado também está ligada ao binômio instabilidade-tempo de convergência para a solução ideal. Como estes dois parâmetros estão diretamente ligados, foi adotada a solução fazê-los complementares. Assim foi adotada a recomendação de $\operatorname{HAYKIN}^{[125]}$ que recomenda o valor 1 para dividir entre estes dois parâmetros, o que faz com que os ganhos de precisão e tempo de processamento sejam equivalentes sem privilegiar nenhum destes requisitos individualmente, uma vez que o outro poderia comprometer o rendimento da rede sem que o primeiro o compensasse.

Para o número de neurônios foram escolhidos os valores entre 5 e 30 variando de 5 em 5 com base na nas informações disponíveis em literatura ${ }^{[134]}$.

\subsubsection{CONJUNTOS DE DADOS TESTADOS}

As redes foram testadas com os seguintes conjuntos de dados:
a) dados reais
b) dados sintéticos
c) dados mistos "a" e "b" acima

Por dados reais entendem-se os resultados diretamente obtidos nos processos como, por exemplo, valores de composição química, da abertura da sangria, etc. correlacionados com os parâmetros de entrada como, por exemplo, as velocidades de corte e espessura da chapa.

O conjunto de dados sintéticos consiste em uma grande quantidade de valores gerados como massa para o treinamento da rede ocorrer de forma mais rápida. Normalmente são utilizados dados reais com a adição de ruídos que perturbem a 
identificação direta, mas informem a rede a tendência de comportamento dos dados. Para esta tese os dados sintéticos foram gerados por regressão linear múltipla aplicada ao conjunto de dados reais e contaminados com a tolerância de aquisição dos dados que foi aleatoriamente distribuída com uma rotina feita no software Excel com a função “ALEATÓRIO”. Isto garantiu a total imparcialidade na criação destes dados, e a utilização de dados com boa capacidade de treinamento e uma rede, mas sem induzi-la a "overfitting" ou seja, um conjunto de dados tão especifico que, ao ser empregado para treinar uma rede, esta apresente precisão tão grande, que perca completamente a capacidade de generalizar.

A utilização da tolerância da aquisição da medida para geração de dados sintéticos proposta nesta tese, significa trabalhar com uma faixa de dados onde o valor medido com grande probabilidade se encontre, ao invés de contaminar uma rede com dados inexistentes, propiciando um rápido treinamento sem a formação de overfitting.

Os dados mistos, consistem em conjuntos de dados construídos aleatoriamente com dados dos 2 conjuntos anteriores.

Todos os conjuntos de dados foram utilizados na proporção $75 \%$ para treinamento e $25 \%$ para validação.

De todas as configurações escolhidas, os resultados foram avaliados considerando os critérios: média dos erros e desvio padrão. Foi também analisado o cálculo do IAR (Índice de Avaliação de Redes) ${ }^{[133]}$.

No caso das redes configuradas para este trabalho, a melhor configuração foi obtida em média com 8 dias de processamento. Todas as redes testadas tiveram seus parâmetros de configuração armazenados. Os resultados das redes são apresentados a seguir.

\subsubsection{ESTIMATIVA DA COMPOSIÇÃO DOS ÓXIDOS COM REDES NEURAIS}

As estimativas de resultados com geradas com Redes Neurais não levam em consideração cada um dos tratamentos utilizados. A idéia é exatamente criar um modelo 
robusto que responda a todas as condições que as redes foram testadas, nomeadamente chapas de diferentes espessuras, diferentes temperaturas e diferentes concentrações de $\mathrm{O}_{2}$.

Por esta razão, os conjuntos de dados não são identificados, sendo apresentados apenas os valores reais e os resultados obtidos pelas redes. As redes e os parâmetros de configuração utilizados em sua arquitetura são apresentadas à seguir:

\subsubsection{ESTIMATIVA DO TEOR DE MAGNETITA NA ESCÓRIA}

A melhor rede para estimativa do teor de magnetita na escória apresentou os seguintes parâmetros de configuração:

Constante de momentum: 0,2

Taxa de aprendizado "learning rate" 0,8

Quantidade de neurônios: 25

Correlação dados reais com a rede nos valores testados: $94,58 \%$

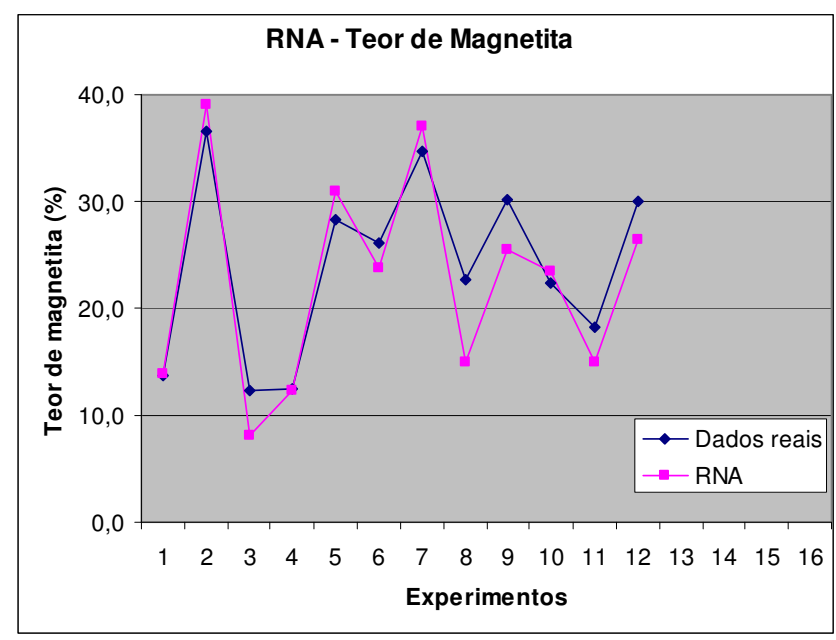

Figura 46 - Rede Neural para estimativa do teor de Magnetita na escória

\subsubsection{ESTIMATIVA DO TEOR DE WUSTITA NA ESCÓRIA}

A melhor rede para estimativa do teor de wustita na escória apresentou os seguintes parâmetros de configuração: 
Constante de momentum: 0,2

Taxa de aprendizado "learning rate" 0,8

Quantidade de neurônios: 15

Correlação dados reais com a rede nos valores testados: $96,11 \%$

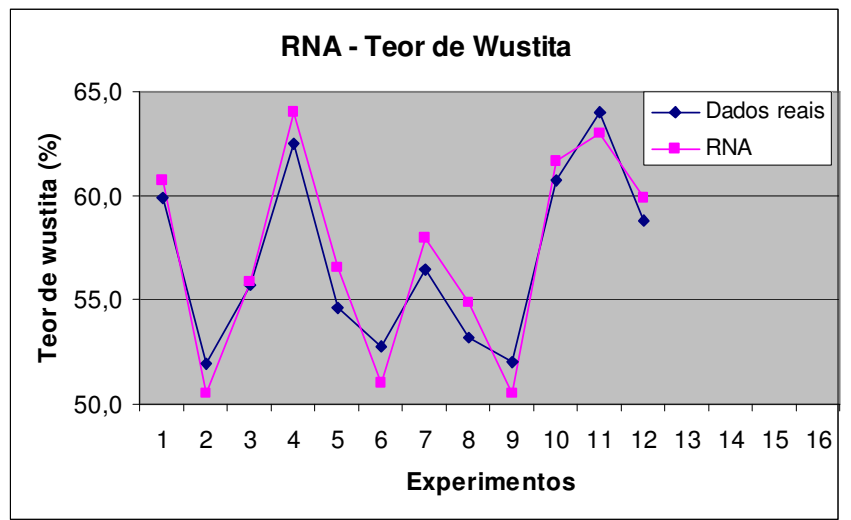

Figura 47 - Rede Neural para estimativa do teor de Wustita na escória

\subsubsection{ESTIMATIVA DO TEOR DE FERRO NA ESCÓRIA}

A melhor rede para estimativa do teor de Fe na escória apresentou os seguintes parâmetros de configuração:

Constante de momentum: 0,5

Taxa de aprendizado "learning rate" 0,5

Quantidade de neurônios: 20

Correlação dados reais com a rede nos valores testados: $98,13 \%$

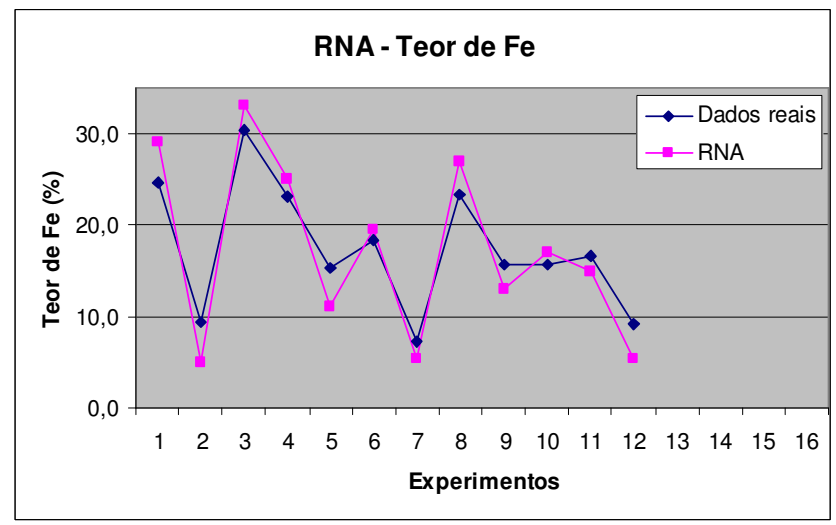

Figura 48 - Rede Neural para estimativa do teor de Fe na escória 


\subsubsection{ESTIMATIVA DAS DIMENSOES DA ESPESSURA DA ZONA FUNDIDA COM A UTILIZAÇÃO DE REDES NEURAIS}

A melhor rede para estimativa da dimensão da zona fundida na parte superior do corte apresentou os seguintes parâmetros de configuração:

Constante de momentum: 0,5

Taxa de aprendizado "learning rate" 0,5

Quantidade de neurônios: 5

Correlação dados reais com a rede nos valores testados: 95,35\%

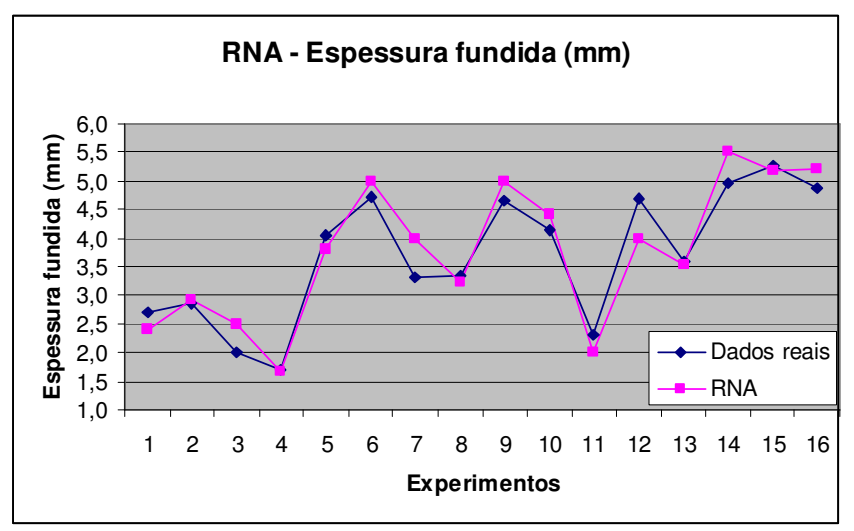

Figura 49 - Rede Neural para estimativa da dimensão da zona fundida na peça

\subsubsection{ESTIMATIVA DAS DIMENSOES DA LARGURA DA SANGRIA COM A UTILIZAÇÃO DE REDES NEURAIS}

A melhor rede para estimativa da dimensão da largura da sangria apresentou os seguintes parâmetros de configuração:

Constante de momentum: 0,2

Taxa de aprendizado "learning rate" 0,8

Quantidade de neurônios: 25

Correlação dados reais com a rede nos valores testados: 95,23\% 


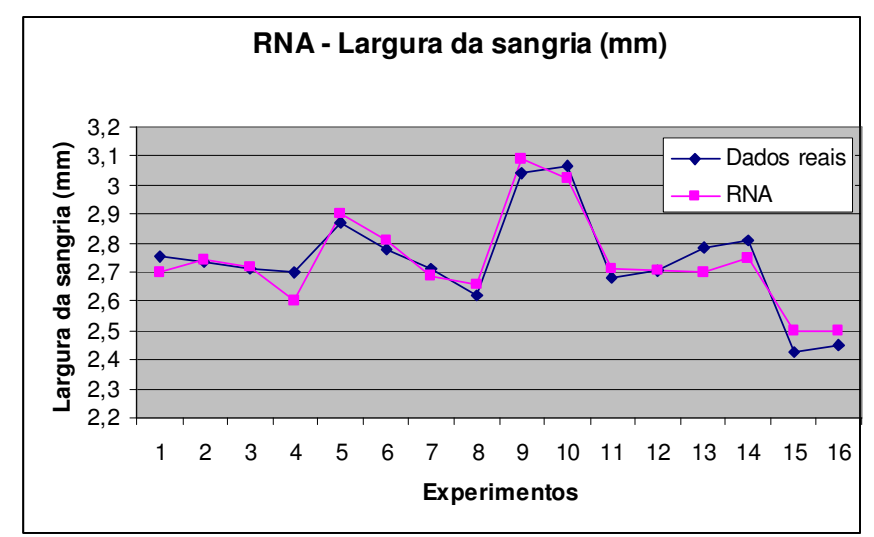

Figura 50 - Rede Neural para estimativa da dimensão da largura da sangria nas peças

\subsubsection{RESUMO DAS CONFIGURAÇÕES UTILIZADAS NAS RNAS}

Como já citado, todas as redes tiveram como dados de entrada as variações dos tratamentos utilizados nesta tese, nomeadamente concentração do $\mathrm{O}_{2}$, temperatura e espessura, e como dados de saída estimaram os valores das composições químicas dos óxidos, enquanto as duas últimas redes calcularam os valores da largura da sangria e a espessura da zona fundida. Um resumo de todas as configurações de redes utilizadas é apresentado a seguir:

\section{TABELA 27 - CONFIGURAÇÕES DAS REDES UTILIZADAS}

\begin{tabular}{|l|c|c|c|c|c|}
\hline & & & & & \\
\hline & Magnetita & Wustita & Fe & Espessura & Larg. sangria \\
\hline Momentum & 0,2 & 0,2 & 0,5 & 0,5 & 0,2 \\
\hline Learning Rate & 0,8 & 0,8 & 0,5 & 0,5 & 0,8 \\
\hline Qte. Neurônios & 25 & 15 & 20 & 5 & 25 \\
\hline Correlação & 94,58 & 96,11 & 98,13 & 95,35 & 95,23 \\
\hline
\end{tabular}

\subsubsection{VALIDAÇÃO CRUZADA}

A validação cruzada é o teste feito com dados de corpos de prova que foram cortados e ensaiados mas que seus dados não foram utilizados no treinamento da rede. Visa verificar a eficiência do treinamento da rede conferindo sua resposta à estes dados. Em seguida as respostas são comparadas, e o valor é mensurado para se verificar o \% de acerto, ou seja a correlação. Neste trabalho foram escolhidos 4 corpos de prova para a validação e 12 para o treinamento. 


\subsubsection{1 - VALIDAÇÃO CRUZADA PARA A REDE DO TEOR DE WUSTITA}

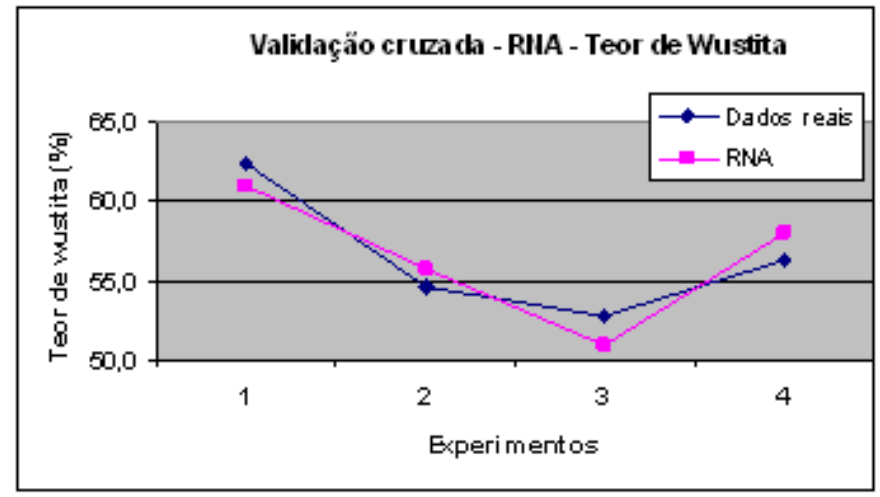

Figura 51 - Validação cruzada da rede para estimativa do teor de wustita

\subsubsection{2 - VALIDAÇÃO CRUZADA PARA A REDE DO TEOR DE MAGNETITA}

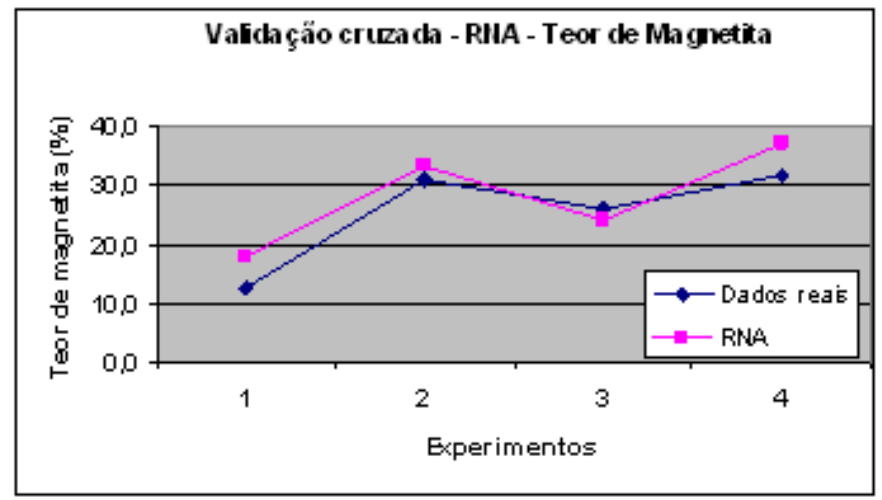

Figura 52 - Validação cruzada da rede para estimativa do teor de magnetita

\subsubsection{3 - VALIDAÇÃO CRUZADA PARA A REDE DO TEOR DE Fe}

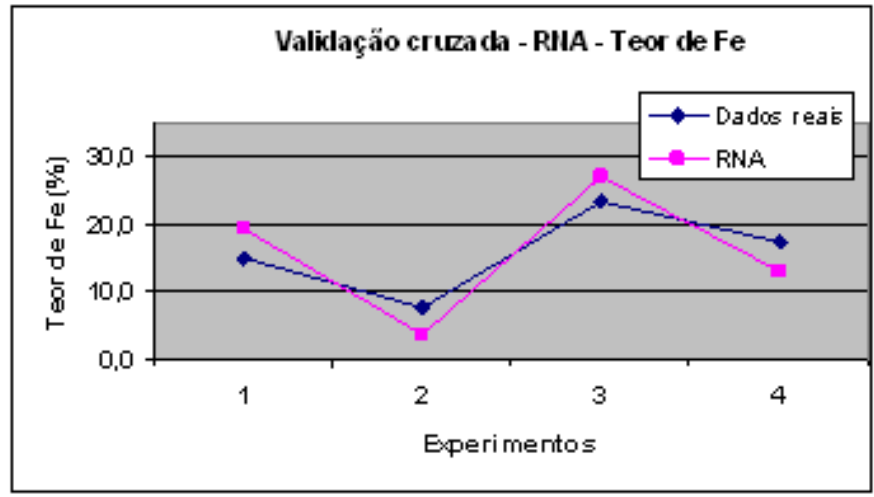

Figura 53 - Validação cruzada da rede para estimativa do teor de ferro metálico 
Nos testes de validação cruzada, as redes responderam respectivamente os resultados de correlação de 91,65\% para o teor de wustita, 89,39\% para o teor de magnetita e $93,20 \%$ na rede do teor de Fe.

Nas redes para a estimativa da largura da sangria e para a medição da espessura fundida, não foi feita a validação cruzada uma vez que foi utilizada a metodologia de duplicação do lote.

Os resultados mostram que as RNA podem ser utilizadas para o estudo proposto nesta tese com taxas de acerto na ordem de 90\%. Deste modo, fica comprovada a viabilidade de calcular a quantidade de energia gerada no processo oxicorte utilizando inteligência artificial para a estimação dos valores das composições químicas dos óxidos gerados no processo. 


\section{CONCLUSÕES}

Com base nos materiais e técnicas utilizadas é possível concluir que:

1. Para o aço carbono ASTM A36 utilizado, a composição química média da escória produzida apresenta basicamente wustita $(\mathrm{FeO})$, magnetita $\left(\mathrm{Fe}_{3} \mathrm{O}_{4}\right)$ e $\mathrm{Fe}$ metálico. Os demais constituintes como hematita $\left(\mathrm{Fe}_{2} \mathrm{O}_{3}\right)$, goethita $(\mathrm{FeOOH}), \mathrm{MnO}_{2}$ (Akhtenskita), $\mathrm{Na}_{0,3} \mathrm{Fe}_{2} \mathrm{Si}_{4} \mathrm{O}_{10}(\mathrm{OH})_{2} \cdot 4 \mathrm{H}_{2} \mathrm{O}$ (Nontronita) e $\mathrm{Fe}_{2,719} \mathrm{O}_{4} \mathrm{Si}_{0,281}$ (óxido de $\mathrm{Fe}$ e $\mathrm{Si}$ ), são encontrados em proporções pequenas e muito próximas dos limites de detecção das técnicas aplicadas;

2. As composições químicas médias dos dois principais óxidos produzidos são: wustita (48 a 66\%) e magnetita (12 a 38\%). Além dos óxidos a escória também apresenta Fe metálico com teores entre ( 7 a $31 \%)$;

3. O Fe metálico encontrado na escória é parte proveniente da fusão da borda superior e parte proveniente de arrancamento durante o processo. Isto é evidenciado pela correlação existente entre o teor de Fe encontrado na escória com a área fundida superior, calculada pelo produto da espessura da zona fundida pela largura da sangria.

4. A composição química da escória é resultado basicamente da composição química e da temperatura da chapa a ser cortada. É bastante influenciada também pela concentração do oxigênio de corte utilizado e pela espessura do material;

5. A variação na concentração do oxigênio de corte ou na temperatura de préaquecimento da chapa a cortar, mesmo sem alteração em nenhum outro parâmetro, causa significativas alterações no balanço energético e nas dimensões na superfície cortada;

6. A espessura da zona fundida na parte superior do corte apresentou grande variação apesar de terem sido mantidos constantes os 3 principais parâmetros normalmente 
associados à variação desta dimensão: a distância bico-peça, a velocidade de corte e a potência da chama;

7. As quantidades de calor envolvidas no processo de corte por oxidação são na verdade uma soma do calor produzido pela chama, pela oxidação do Fe e pela combustão e oxidação das impurezas;

8. Pode-se calcular as quantidades de calor envolvidas no processo utilizando-se informações da área fundida, extensão da ZAC ou a largura da sangria;

9. O calor envolvido no processo é predominantemente produzido pela chama nas chapas de espessuras finas e pela reação de oxidação nas chapas grossas. Calculando estes dois valores para varias espessuras é possível entender, para uma espessura em questão, qual o mecanismo principal de fornecimento de calor.

10. Compreender o exposto na conclusão acima é essencial para evitar equívocos na avaliação do processo como, por exemplo, utilização de meios que potencializam a geração de calor num dado mecanismo de fornecimento, quando a espessura em questão encontra-se em outro. (exemplo: utilização de combustíveis de alto poder calorífico para corte de chapas de grandes espessuras);

11. As quantidades de calor calculadas pelos dois modelos possibilitam o cálculo com boa fidelidade das quantidades de calor envolvidas no processo. Os valores obtidos foram validados por experimentos práticos;

12. Dadas as condições peculiares de óxidos de ferro, a análise e quantificação do material produzido na escória do processo oxicorte pode ser feita dividindo-se o material em frações passante a 0,074 mm (finos) e outra não passante (grossos), analisa-se cada uma separadamente e quantifica-se o total através do balanço de massa. A parte fina pode ser quantificada com grande precisão com a técnica de DRX com quantificação por método de Rietveld, enquanto a fração grossa apresenta maiores dificuldades de quantificação por ser uma fase dúctil dificilmente 
cominuída por métodos de impacto/abrasão usuais de preparação, mas responde bem a análise qualitativa quando analisada com a técnica de DRX.

13. O procedimento de refinamento desenvolvido no método de Rietveld na difração de raios $\mathrm{X}$ mostrou-se adequado para a quantificação dos óxidos de ferro produzidos no processo, tendo seus resultados comprovados com espectroscopia de Mossbauer.

14. A técnica de inteligência artificial Redes Neurais Artificiais possibilita a criação de um modelo robusto que correlacione a temperatura de pré-aquecimento, a concentração do oxigênio e as espessuras utilizadas com os resultados da operação de corte: taxa de remoção de material por área oxidada, composição química dos óxidos, largura da sangria ou rugosidade com grande precisão, o que faz da utilização das RNA uma excelente técnica para o estudo do processo de uma forma econômica e com excelente capacidade de reprodução do seu comportamento. 


\section{SUGESTÕES DE TRABALHOS FUTUROS}

Este trabalho levanta algumas diretrizes de estudo não puderam ser abordadas por limitações de recursos, tempo e principalmente para evitar afastar-se da linha central do estudo aqui apresentado, onde a comparação de cortes de chapas em diferentes espessuras foi feita com uma regulagem única de parâmetros visando comparar os resultados, sem o ajuste individualizado dos parâmetros de corte para cada espessura estudada.

Assim, os tópicos à seguir, levantados no decorrer da realização deste trabalho, são aqui apresentados como sugestões para estudos que venham a prosseguir com o assunto aqui apresentado, expandi-lo ou mesmo investigar novos tópicos na pesquisa tanto do processo oxicorte quanto das demais técnicas aqui utilizadas:

a) - Estudar a formação dos óxidos e o fluxo do calor nas condições de regulagem específica de cada uma das diferentes espessuras analisadas.

b) - Estudar comparativamente os mesmos tópicos aqui levantados com a utilização de diferentes combustíveis, como por exemplo GLP e propileno, que são gases alternativos ao acetileno e apresentam menos problemas ambientais em sua produção e menor temperatura de chama.

c) - Estudar espessuras diferentes das analisadas, principalmente chapas de espessuras menores que as pesquisadas.

d) - Verificar a robustez dos modelos projetados com redes neurais aumentando tanto a quantidade de variáveis pesquisadas quanto os limites de variação nos parâmetros já estudados,

e) - Com base em medidas simples como o produto da medida da espessura da zona fundida pela largura da sangria, ajustar equações para o estudo do fluxo de calor especificas para o processo e validá-las com experimentos práticos. Isto minimizará custos de ensaios e tornará o processo mais fácil de ser simulado sem grandes exigências de capacidade de programas (softwares), equipamentos (hardware) e qualificação de pessoal. 


\section{REFERÊNCIAS BIBLIOGRÁFICAS}

1 ROSENTHAL, D. Mathematical Theory of Heat Distribution During Welding and Cutting. Welding Research Supplement. EUA, 1941. p.220-234.

2 GLIZMANENKO, D. E.; YEVSEYEV, G. Gas welding and cutting. Moscou: Peace Publishers, 1960. 430 p.

3 RAMALHO, J.P.; JOAQUIM, R. Corte por alta densidade de energia: LASER \& jato de água. In: CONGRESSO BRASILEIRO DE SOLDAGEM, XXI., Caxias do Sul, 1995. Anais. São Paulo: ABS, 1995. p.433-450.

4 ARANTES, L.J. O atual estágio da usinagem híbrida por jato de água e descargas elétricas. Revista MM, Editora Aranda, São Paulo, março/2004, p.104-113, 2004.

5 JOAQUIM, R.; RAMALHO, J.P. Corte plasma $\mathbf{x}$ oxicorte, algumas considerações. In: CONGRESSO BRASILEIRO DE SOLDAGEM, XX., Contagem, 1994. Anais. São Paulo: ABS, 1994. p.125-138.

6 HIDDEN, S. E BUHLER, B. The great debate: Plasma or oxy-fuel? In: Welding Journal, num. 03/05. USA: 2005. p.40-44.

7 AGA. Latin America Center. Comparativo entre processamento a LASER e outros métodos de corte e solda: Material promocional 1992. Brasil: p.1-5

8 AGA. Latin America Center. Como seleccionar el sistema ideal de corte térmico: Material promocional 1994. Chile: p.3-15

9 IRVING, B. Plate cutting for welding prep: An untapped source in the productivity equation: In: Welding Journal, num. 05/98. USA: 1998. p.3944.

10 BOURTON, M.; MACKRIDGE, L.; ANDERSON, P. Cutting the cost of cutting: In: TWI Bulletin, num. 2. Inglaterra: 1995. p.35-37. 
11 ESAB. Cutting technology in shipbuilding. Revista Svetsaren 2005. Karben, Alémanha: p.27-30.

12 MAIR, H. e PLEBUCH, F.C. A comparison of the thermal cutting processes. In “ANNUAL WELDING CONFERENCE '94" Bremen 1994. Anais. Alémanha: Linde 1994 p.3-18.

13 SCHLÜTER, H. Corte com sistemas a LASER CO2 evolui com novos recursos. Revista MM, Editora Aranda, São Paulo, março/2004, p.134-143, 2004.

14 AGA. Competence Center. Productivity and quality. Relatório interno 1987. Lindigö: $35 p$.

15 HYPERTERM. Powermax, guia de referência do produto. Material de folheto promocional da Hyperterm do Brasil. 2007, p.7.

16 ALMEIDA, M.B.Q. Oxicorte. Rio de Janeiro: Editora FIRJAN/SENAI, 2000, $78 \mathrm{p}$.

17 PARANHOS, R. Segurança em Operações de Soldagem e Corte. Rio de Janeiro: Editora FIRJAN/SENAI, 1998, 54p.

18 HOUldCROFT, P.; ROBERT, J. Welding and Cutting, a Guide to Fusion Welding and Associated Cutting Processes. Inglaterra: Editora WoodheadFaulkner, 1988, p. 202-205

19 CSST - Service du Répertoire Toxicologique. Gaz et fumées de soudage et de coupage $\quad$ França. $1996 . \quad$ Disponível em <http://www.reptox.csst.qc.ca/Produit.asp?no_produit=13896> Acesso em: 07/07/2007

20 AHLbERG, K. (Ed.) AGA Gas Handbook, First Edition. Suécia: Almqvist \& Wiksell Tryckery AB, 1985. 582 p. 
21 GLIZMANENKO, D.; YEVSEYEV, G. Op. cit. p. 25

22 CHIAVERINI, V. Tecnologia Mecânica - Materiais de construção mecânica, vol II. Brasil: Editora McGraw-Hill, 1978. p.34

23 SLOTTMAN, G.V.; ROPER, E.H. Historical Review. In: Oxygen cutting. New York: Editora McGRAW-HILL, 1951. p. 4-12.

24 LENSI, M. Solda Oxiacetilênica para técnicos, especialistas e aprendizes do ramo. Brasil: Editora Hemus, 1975, p. 44

25 AGA. Competence Center. Facts about backfire and flashback. Relatório interno 1996. Lindigö, Suécia: 11p.

26 BRODEN, G. Use of Hydrogen Generators for Flame Processes. AGA Manufacturing Industry Internal Report. 1995. Lindigö: 10p.

27 FAHLÉN, L. Función de la llama de calentamiento en el oxicorte. AGA Gas AB Informe de la industria metalmecánica. 1995. Sundbyberg, Suécia: 10p.

28 MARRA, E. O corte de chapas através do oxicombustível. In: SIDERURGIA BRASIL, ano 4 n 10. São Paulo, Grips Editora. mar-abr 2003, p.12-19

29 PRIVOZNIK,L.J. e LIGHT JR, S.C. Mechanized flame cutting of beveled mitre joints. Estados Unidos da América: Welding Journal, volume $61 \mathrm{n}^{\circ} 8$ august 1982. p.37-40

30 TWI. Job knowlwdge for welders. In: Magazine and Journal of TWI and the Welding \& Joining Society, nº72, dez. 1995. Cambridge Inglaterra: p.6-7

31 VAN HORN, C.A. Fuel gases: How to pick the right one for your shop. Estados Unidos da América: Welding Design \& Fabrication, vol 49, n 10 october 1976. p.67-77

32 AGA. Competence Center. The right fuel gas will increase productivity in your machine cutting. Relatório interno 1995. Lindigö: 12p. 
33 HEWITT, A.D. Technology of oxy-fuel gas processes, part 1: General Principles Involved. In: Welding and Metal Fabrication. London. IIW, 1972. p.318-322

34 __ Technology of oxy-fuel gas processes, part 1 continued: General Principles Involved. In: Welding and Metal Fabrication. London. IIW, 1972. p. $347-350$

35 __ Technology of oxy-fuel gas processes, part 2: Comparative Combustion Properties of Fuel Gases. In: Welding and Metal Fabrication. London. IIW, 1972. p.382-389

36 __ Technology of oxy-fuel gas processes, part 3: The Choice of Suitable Fuel Gases. In: Welding and Metal Fabrication. London. IIW, 1972. p.416422

37 LUCAS, B.; HILTON, D. Processos de corte: Aplicação de corte oxicombustível: In: Soldagem e Inspeção, num. 11/00. Brasil: 2000. p.20-22.

38 __ Corte oxicombustível: Processo e gases combustíveis In: Soldagem e Inspeção, num. 8/00. Brasil: 2000. p.21-23.

39 VAN HORN, C.A. Cutting equipment keeps up with materials. Estados Unidos da América: Welding Design \& Fabrication, vol 51, no 2 february 1978. p.63-67

40 DERMOTT, R.G. Cost-cutting tips on joint preparation. Estados Unidos da América: Welding Design \& Fabrication, vol 49, nº 9 september 1976. p.61

41 RAMALHO, J. et al. Preparação de juntas e processos de corte. In: TATINI, I.; ZIEDAS, S. (Org.) Soldagem. São Paulo. SENAI, 1997. p.343

42 Machado, I. G. Soldagem e Técnicas Conexas. Porto Alegre: Editado pelo autor, 1996. p.313-328 e 371-388 
43 WAINER, E. Soldagem Oxigás. In: WAINER, E. (Org.) Soldagem. São Paulo. ABS, 1977. p. 10

44 RANGel, R.N, In: Práticas de Físico Química. São Paulo. Editora Editora Edgard Blucher, 1998. 266 p.

45 OHLWEILLER, O.A. Introdução à Quimica Geral. Porto Alegre. Editora Globo, 1967. p 36.

46 SCOTTI, A. Corte de metais a arco e oxigênio. In: Apostila do curso de Supervisores de Soldagem para a Área Nuclear Rio de Janeiro. IBQN, 1987. $27 \mathrm{p}$.

47 AGA. Competence Center. Thermal cutting + WJC: Relatório interno 2000. Lindigö: 49p.

48 AGA. Competence Center. Facts about oxy cutting. Relatório interno 1996. Lindigö: 16p.

49 BRANDI, S. Soldagem com gás. In: WAINER, E.; BRANDI, S.; MELLO, F.D.H. Soldagem. São Paulo: Editora Edgard Blücher. 1995, p.180-216

50 AlströN, C.; BRODEN, G. Nox and CO-Emission From Flames. AGA Manufacturing Industry Internal Report. 1995. Lindigö: 19p.

51 Ramalho, J. Processo Oxicorte. Brasil. 2007. Artigo técnico disponivel na seção "processos de corte" no site infosolda. Disponível em $<$ http://www.infosolda.com.br/download/62ddm.pdf $>$. Acesso em: $13 / 12 / 2007$

52 EKLUND, G. Fuel gas and their proprieties. Swedish Institute for Metals Research. Internal Report. 1978. Stockholm: 37p.

$53 \mathrm{COUCH}$, M.F. e SILKNITTER, D.H. Economic evaluation of fuel gases for oxyfuel gas cutting in steel fabrication. In: Welding Journal, num. 10/67. USA: 1967. p.825-832. 
54 AGA. Competence Center. Fatos sobre gases combustíveis. Material promocional da AGA S/A 1996. São Paulo: 24p.

55 CAMACHO, J.L.P. Explanação sobre combustíveis e combustão. São Paulo, USP, 20/03/03. Depoimento a José Pinto Ramalho.

56 REED, R.J. North American Combustion Handbook, Third Edition, Volume II, USA: 1997. 432p.

57 ROSENQVIST, T. Principles of Extractive Metallurgy. Japão: Editora McGrawHill 1974 p. 231

58 AGA. Competence Center. The influence of heating on cutting operation. Relatório interno 1994. Lindigö: 44p.

59 LIDE, D. R. Editor in Chief CRC Handboolk of Chemistry and Physics $73^{\mathrm{a}}$ edição CRC press EUA 1993

60 SCHIMPKE, P.; HORN, H.A. Tratado General de Soldadura - Tomo 1 Soldadura y corte côn soplete. Barcelona: Editora Gustavo Gili S/A, 1963 p.313-341

61 TURKdogan, E. T. Physical Chemistry of High Temperature Technology. EUA: 1980. Academic Press, 484 p.

62 ELliOT, J. F.; GLEISER, M.; RAMAKRISHNA, V. Thermochemistry for Steelmaking, Thermodynamic and Transport Properties. Londres: 1975. Addison-Wesley Publishing Company, Inc., 484 p.

63 AGA. Competence Center. Facts about the influence of shop primers on the flame cutting. Relatório interno 1996. Lindigö: 11p.

64 ONO, C. Explanação sobre equipamentos para corte com gases combustíveis. São Paulo, AGA, 17/08/03. Depoimento a José Pinto Ramalho. 
65 RAMALHO, J. P. Modernos processos de corte de metais. In: Siderurgia Brasil, ano 6 n 27. São Paulo, Grips Editora. nov-dez 2005, p.52-57.

66 AGA. Competence Center. Thermal cutting + WJC: Relatório interno 2000. Lindigö: 49p.

67 MARRA, E. Princípios para um oxicorte eficiente. In: SIDERURGIA BRASIL, ano 7 n $^{\circ}$ 32. São Paulo, Grips Editora. set-out 2006, p.22-27

68 ROSSI, B. E. Oxygen and arc cutting of metals. In: Welding Engineering. New York: McGraw-Hill Book Company. 1954, p.319-345

69 AGA. Manual para Oxi-Corte à Máquina. Material promocional da AGA do Brasil. 1999, p.26.

70 SAF. Guia do soldador de soldadura manual. Material promocional da SAF de Portugal. 1981, p.75.

71 NICOLAI, M. Flame cutting in modern industrial production. EUA: Welding Review, november 1983. p.297-300

72 MORRIS, J. L. Welding: Processes and Procedures. EUA: 1954. Prentice Hall, p. $202-221$

73 GRANJON, H. e ROSEMBERG, P. Coupage des fers et aciers par les chalumeaux a jet d'oxygene. In: MANUEL PRATIQUE DE SOUDURE AUTOGÈNE, sixième mille (deuxième édition) 1912. Paris, Bibliothèque de l’Office Central de Acétylène, p.324-348

74 NICOLAI, M.L.; GRAHAN, A. Flame cutting in modern industrial production. In: Welding Review Magazine, num. 11. USA. 1983, p.297-300.

75 BERNARD, A. Oxy fuel cutting and welding In: Welding Design \& Fabrication, num. 6. USA. 1991, p.17-57. 
76 LINDE. Oxygen / Fuel Gas Cutting - Tips for practitioners. Material de folheto promocional da Linde da Alémanha. 2002, p.1-4.

77 JEZEK, B. What's your cutting trouble. In: Welding Journal, num. 12/79. USA: 1979. p.76-80.

78 JOAQUIM, R. e RAMALHO, J. OXICORTE. Disponível em $<$ http://www.metalica.com.br/pg dinamica/bin/pg dinamica/php?id_pag=703 $>$. Acesso em 18/11/2006

79 BRANDI, S. Soldagem com gás. In: WAINER, E.; BRANDI, S.; MELLO, F.D.H. Soldagem. São Paulo: Editora Edgard Blücher. 1995, p.180-216

80 KRAMM, R. Corte de chapas com oxigênio: produtividade com economia. In: Revista Máquinas e Metais, num. 12. São Paulo: 1992. p.24-33

81 IRVING, B. Plate cutting for weld prep: an untapped source in the productivity equation. In: Welding Journal, num. 5/98. USA: 1998. p.39-44.

82 SAEZ, M. Rentabilité en oxycoupage. In: Soudage et Techniques Connexes, num1/2. França: 1986. p.1-6

83 AGA. Latin America Center. Hacia una Mayor Productividad: Relatório interno 1984. Venezuela: p.19

84 KOU, S. Heat Flow During Welding. in: Welding Metallurgy. EUA: Ed. John Wiley \& Sons, 1987. p.29-59.

85 GRONG, O. Heat Flow and Temperature Distribution in Welding. in: Metallurgical Modeling of Welding Second Edition. Inglaterra: Ed. H. K. D. H. Bhadeshia, 1996. p.1-112.

86 MACHADO, I - Condução do Calor na Soldagem, Fundamentos e Aplicações. São Paulo: Editora Imprensa Livre, 2000. 119 p. 
87 RAMALHO, J.P., Fluxo de calor no oxicorte. São Paulo. 2007. Seção de artigos técnicos do site infosolda. Disponível em $<$ http://www.infosolda.com.br/download/99xxx.pdf $>$. Acesso em: 13/11/2006

88 MYERS, P. S.; UYEHARA, O. A.; BORMAN, G. L. Fundamentals of Heat Flow in Welding In: Welding Research Council Bulletin. Bulletin 123. EUA: $196750 \mathrm{p}$.

89 CHRISTENSEN, N.;.Davis, V.L.; Gjermundsen, K - "Thermal efficiency in welding processes”. Brit. Weld. J., vol. 12, pg. 54-75, 1965.

90 LANCASTER, J.F. Metallurgy of welding. Inglaterra Ed. Chapman \& Hall, 1993. p. $35-68$

91 LODOÑO, A.R. e BRANDI, S. Modificação da solução de Rosenthal para a equação de fluxo de calor para a simulação de soldas multipasse. In: ENCONTRO NACIONAL DE TECNOLOGIA DE SOLDAGEM, XXIV., Fortaleza, 1998. Anais. São Paulo: ABS, 1998. p.152-175.

92 RAMALHO, J.P. e BRANDI, S. A imprecisão da equação de Rosenthal no processo oxicorte. SIMPÓSIO DE INICIAÇÃO CIENTÍFICA E TECNOLÓGICA, 5º São Paulo, 2003. Boletim Técnico nº15. São Paulo: FATEC, 2003. p.27.

93 ADAMIAN, R. Termoquímica Metalúrgica. São Paulo: Editora: Associação Brasileira de Metais, 1985. p. 303

94 PERRY, R. H.; CHILtON, C.H. Manual de Engenharia Química. Rio de Janeiro: Editora: Guanabara Dois, 5'. Edição, 1980. p. 3-145 a 3.161.

95 LIMA, E. Alternativa para o corte de metais. In: SIDERURGIA BRASIL, ano 6 $n^{\circ}$ 38. São Paulo, Grips Editora. out 2007, p.16-21

96 CAStellan, G.; Fundamentos da Físico Química. Rio de Janeiro: Editora: LTC, $1^{\text {a }}$. Edição, 1986. p. 506. 
97 RUSSEL, J.; Química Geral. São Paulo: Editora: McGraw Hill, 2ª Edição, 1982. p. 869.

98 HUME-ROTHERY, W.; Estrutura das ligas de ferro. São Paulo: Editora: Edgard Blücher, 2 ${ }^{a}$. Edição, 1971. p. 107.

99 FONSECA, M.R.M.; Físico-Química. São Paulo: Editora: FTD, 1ª Edição, 1992. p. 103.

100 RANGEL, R.N.; Práticas da Físico-Química. São Paulo: Editora: Edgard Blücher, 2a. Edição, 1997. p. 123.

101 SANTOS, J.F.O. e QUINTINO, L. Processos de Soldadura. Lisboa: Editora: Instituto de soldadura e Qualidade - ISQ, 1 ${ }^{\text {a }}$. Edição, 1993. 275 p.

102 GENTIL, V. Corrosão. Rio de Janeiro: Editora Guanabara S.A. 1987, p. 184-208

103 SEFERIAN, D. Metallurgie de la soudure. França: Editora Dunod, 1959. p. 24

104 WHITE MARTINS. Catálogo Geral 84/85. Material promocional 1984. Brasil: $84 \mathrm{p}$.

105 ENGBlOM, G. Recentes Desenvolvimentos do Oxicorte. In: CONGRESSO BRASILEIRO DE SOLDAGEM, XIII., Guarujá, 1987. Anais. São Paulo: ABS, 1988. p.231-270.

106 LEVENSPIEL, O. Engenharia das Reações Químicas, volume 2 Cálculo de Reatores. São Paulo: Editora Edgard Blucher Ltda, 1987. p. 303

107 RAMALHO, J.P. e BRANDI, S. Estudo cinético-metalúrgico do processo oxicorte. SIMPÓSIO DE INICIAÇÃO CIENTÍFICA E TECNOLÓGICA, 5, São Paulo, 2003. Boletim Técnico nº15. São Paulo: FATEC, 2003. p.26.

108 TAVARES, R.P. Termodinâmica e cinética da injeção de carvão e outros materiais pulverizados no alto-forno In: Paulo Santos Assis (Org.) Injeção de materiais pulverizados em altos fornos. São Paulo. ABM - Associação Brasileira de Metalurgia e Materiais, 1993. p.56 
109 AWS Welding Handbook. Estados Unidos: American Welding Society Welding Processes. part1 v.2 9ª Edição. Miami EUA 2004. p. 597-636.

110 LABOURIAU, F. C. Aspectos relacionados com a pureza do $\mathrm{O}_{2}$ no oxicorte In: CONGRESSO BRASILEIRO DE SOLDAGEM, XIV., Gramado RS, 1988. Anais. São Paulo: ABS, 1988. p.381-396.

111 MACKRIDGE, L. et al. Cutting the Cost of Cutting In: TWI World Center for Materials Joining Technology. Bulletin 2, vol 36. Inglaterra: 1995 p.4

112 RAMALHO, J.P., BRANDI, S.D. e ISSA, F.M.R. Estudo da influência de parâmetros de corte na largura da sangria no processo oxicorte. In: CONGRESSO BRASILEIRO DE SOLDAGEM, XXXIII, Caxias do Sul-RS, 2007. Anais. São Paulo: ABS, 2007. p.48-56.

113 RAMALHO, J.P., BRANDI, S.D. Estudo da variação da temperatura e da pureza do oxigênio na composição dos óxidos no processo oxicorte. In: IIW INTERNATIONAL CONGRESS 2nd Latin American Welding Congress, São Paulo, 2008. Anais. São Paulo: ABS, 2008. (aceito para publicação em 03/03/08)

114 BRANDI, S. et al. Metalurgia da Soldagem: Transferência de calor. In: TATINI, I.; ZIEDAS, S. (Org.) Soldagem. São Paulo. SENAI, 1997. p.93

115 ORGANISATION INTERNATIONALE DE NORMALISATION. Coupage thermique - Classification des coupes thermiques - Spécification géométrique des produits et tolérances relatives à la qualité - ISO 9013 Geneve, 2000. 23 p.

116 AGA. Latin America Center. Fatos sobre: Classificação de qualidade de superfícies cortadas termicamente: Material promocional 1999. Brasil: p.11

117 ANTONIASSI, J.L. Caracterização mineralógica em bauxitas de Porto Trombetas, PA. 2006. 91p. Monografia de trabalho de formatura - Instituto de Geociências, Universidade de São Paulo. São Paulo, 2006. 
118 REYNOLDS, R.C.Jr.; Principles of powder diffraction. EUA: Modern Powder Diffraction, vol. 20, 1996, p.1-17.

119 RAMALHO, J.P., ANTONIASSI, J.L., SANT’AGOSTINO, L.M., BRANDI, S.D. Aplicação da DRX-Rietveld na quantificação de óxidos de ferro produzidos no oxicorte. In: IIW INTERNATIONAL CONGRESS 2nd Latin American Welding Congress, São Paulo, 2008. Anais. São Paulo: ABS, 2008. (aceito para publicação em 03/03/08)

120 BRANCO, C.M.; FERNANDES, A.A. e CASTRO, P.M.S.T. Fadiga de Estruturas Soldadas. Lisboa: Editora da Fundação Calouste Gulbenkian. 1986 p. $875-881$

121 CARVALHO, André C.P.L.F., Redes Neurais. São Carlos. 2000. Notas de aula do curso de Redes Neurais do LABIC. ICMC USP. Disponível em $<$ http://www.icmc.sc.usp.br/ andre/AULAS/RN/srn06.pdf>. Acesso em: $13 / 11 / 2006$

122 TAFFNER, M. A. Et al. Redes Neurais Artificiais, Introdução e Princípios da Neurocomputação. Blumenau: Editora da FURB, 1995. 199 p.

123 KOVÁCS, Z. L. Redes Neurais Artificiais, Fundamentos e Aplicações. São Paulo: Edição Acadêmica São Paulo, 1996. 163 p.

124 JACKSON, T.; BEALE, R. Neural Computing: An Introduction. EUA: IOP Publishing Ltd, 1992. 240 p.

125 HAYKIN, Simon. Redes Neurais, Princípios e Prática. Porto Alegre: Editora Bookman 2002, 487p.

126 THOMÉ, A. C. G.; OLIVEIRA, A. C., Inteligência Computacional, Redes Neurais. Rio de Janeiro. 2001. Notas de aula do curso de Redes Neurais do Núcleo de Computação Eletrônica. UFRJ. Disponível em $<$ http://equipe.nce.ufrj.br/thome/grad/nn/mat_didatico/ic_grad2002_aula3.pdf $>$.

Acesso em 18/11/2006 
127 SANTOS, V. P.; ROMERO, R. A. F. Utilização do MATLAB para o Desenvolvimento de Redes Neurais. São Carlos: USP, 1994. (Relatório Técnico do Departamento de Ciências da Computação e Estatística, 92/21518)

128 DINIZ, Suelaine dos Santos. Uso de Técnicas Neurais para o Reconhecimento de Comandos à Voz. 1997. 187p. Dissertação (Mestrado) - Instituto Militar de Engenharia, Rio de Janeiro, 1997.

129 ANDRADE, Luciano C. M. e CARVALHO, André C.P.L.F. Aplicações de Redes Neurais na Indústria, Comércio e Medicina. São Carlos: USP, 1997. (Relatório Técnico do Instituto de Ciências Matemáticas, número 52)

130 CAStelhano, G. O. et al. Redes Neurais Artificiais no Monitoramento de Parâmetros de Processo. Revista MM, Editora Aranda, São Paulo, abril/2005, p.194-211, 2005.

131 PEDROZA, L.C.; PEDREIRA, C.E. Uma Nova Metodologia Para Treinamento em Redes Neurais Multicamadas. In: SBA Controle \& Automação, vol 11 no 01 Jan.,Fev.,Mar.,Abril de 2000 Brasil: 2000. p.49-54.

132 SILVA, E.; OLIVEIRA, A. C., Dicas para a Configuração de Redes Neurais. Rio de Janeiro. 2001.. Disponível em $<$ http://www.nce.ufrj.br/labic/downloads/dicas_cfg_rna.pdff $>$. Acesso em: $23 / 11 / 2006$

133 RAMALHO, J. et al. Método para comparação de performance entre redes neurais artificiais. In SIMPÓSIO DE INICIAÇÃO CIENTÍFICA E TECNOLÓGICA, 5ª São Paulo, 2003. Boletim Técnico nº15. São Paulo: FATEC, 2003. p.6.

134 DE CARVAlHO, A.; BRAGA, A.; LUdERMir, T. Fundamentos de Redes Neurais. Rio de Janeiro: Editora Guanabara Dois 1998 p. 98 
135 DIETTERICH, Thomas G. Experimental Methodology for Benchmarking. USA. 2000. Oregon State University, Department of Computer Science Disponível em http://wwwipd.ira.uka.de/ prechelt/nipsbench/expmeth.ps.gz Acesso em: 26/11/2006

136 FLEXER, Arthur. Statistical Evaluation of Neural Network Experiments: Minimum Requirements and Current Practice. Viena. 1996. The Austrian Research Institute For Artificial Intelligence. Disponível em <ftp://ftp.ai.univie.ac.at/papers/oefai-tr-95-16.ps.gz>. Acesso em: 29/11/2006

137 PRECHELT, Lutz. Proben 1 - A set of Neural Network Benchmark Problems and Benchmark Rules. Alémanha. 1994. Fakultat für Informatik von Karlsuhe. Disponível em $<$ http://www.poli.usp.br/d/pmr5406/Download/Metodologia/proben.ps $>$ Acesso em: 29/11/2006

138 DIETTERICH, Thomas. Approximate Statistical Tests for Comparing Supervised Classification Learning Algorithms. USA. 1994. Oregon State University, Department of Computer Science. Disponível em <ftp://ftp.cs.orst.edu/pub/tgd/papers/nc-stats.ps.gz> Acesso em: 30/11/2006

139 RAMALHO, J.P., BRANDI, S.D. e ISSA, F.M.R. Modelamento da superfície obtida por oxicorte utilizando redes neurais artificiais. In: CONGRESSO BRASILEIRO DE SOLDAGEM, XXXI., São Paulo, 2005. Anais. São Paulo: ABS, 2005. p.146-156.

140 GALE, W. F., TOTEMEIER , T.C.(Editor) Smithells Metals Reference Book. $8^{\mathrm{a}}$ edição, Elsevier Inc, USA: 2004. p.8-1 a 8-50.

141 KUBASCHEWSKY, O. e ALCOCK, C.B. Metallurgical Thermochemistry. $5^{\text {a }}$ Edição, USA: Pergamon Press, 1979 p.267-356. 